\title{
Novel syntheses of indoles, quinoxalines, 2-quinoxalinones, 2-alkylbenzimidazoles and other heterocycles
}

Jeffery M. Wallace

West Virginia University

Follow this and additional works at: https://researchrepository.wvu.edu/etd

\section{Recommended Citation}

Wallace, Jeffery M., "Novel syntheses of indoles, quinoxalines, 2-quinoxalinones, 2-alkylbenzimidazoles and other heterocycles" (2003). Graduate Theses, Dissertations, and Problem Reports. 1945.

https://researchrepository.wvu.edu/etd/1945

This Dissertation is protected by copyright and/or related rights. It has been brought to you by the The Research Repository @ WVU with permission from the rights-holder(s). You are free to use this Dissertation in any way that is permitted by the copyright and related rights legislation that applies to your use. For other uses you must obtain permission from the rights-holder(s) directly, unless additional rights are indicated by a Creative Commons license in the record and/ or on the work itself. This Dissertation has been accepted for inclusion in WVU Graduate Theses, Dissertations, and Problem Reports collection by an authorized administrator of The Research Repository @ WVU.

For more information, please contact researchrepository@mail.wvu.edu. 


\title{
Novel Syntheses of Indoles, Quinoxalines, 2-Quinoxalinones, 2-Alkylbenzimidazoles and Other Heterocycles
}

\author{
Jeffery M. Wallace
}

\author{
Dissertation \\ Submitted to the Eberly College of Arts and Sciences \\ at \\ West Virginia University \\ in Partial Fulfillment of the Requirements for the Degree of \\ Doctor of Philosophy \\ in \\ Chemistry
}

\author{
Björn C. G. Söderberg, Ph.D., Chair \\ Peter M. Gannett, Ph.D. \\ Fred L. King, Ph.D. \\ John H. Penn, Ph.D. \\ Kung K. Wang, Ph.D. \\ Department of Chemistry \\ Morgantown, West Virginia \\ 2003
}

Keywords: Cyclization Reactions, Palladium, Heteroannulation

Copyright 2003 Jeffery M. Wallace 


\section{Abstract \\ Novel Syntheses of Indoles, Quinoxalines, 2-Quinoxalinones, \\ 2-Alkylbenzimidazoles and Other Heterocycles}

\section{Jeffery M. Wallace}

Using a palladium-catalyzed reductive $N$-heteroannulation methodology previously discovered in our labs, a $20 \mathrm{mmol}$ synthetic route to methyl indole-4-carboxylate has been developed. Methyl indole-4-carboxylate is synthesized in four steps, with the key step being the reductive cyclization of methyl 2-ethenyl-3-nitrobenzoate in good overall yield. This cyclization method has been modified and applied to the preparation of quinoxalines, 2-quinoxalinones and other heterocyclic compounds. We also propose a possible mechanism for these transformations. In addition, a novel method to 2-alkylbenzimidazoles has been developed. The thermal reactions of 2-azidonitrobenzenes with various aldehydes give 2-alkylbenzimidazoles generally in moderate yield. 


\section{Acknowledgements}

I would like to thank my research advisor, Dr. Björn C. G. Söderberg for his constant support, encouragement and understanding during my time at West Virginia University. It has truly been a pleasure. I would also like to thank the members of my graduate committee, Dr. Peter M. Gannett, Dr. Fred L. King, Dr. John H. Penn and Dr. Kung K. Wang, for their time and assistance during my graduate studies.

I am grateful to have had the support and friendship of my coworkers, especially

Jeremiah Hubbard, to help me get through it all.

I wish to thank my family for their never-ending love, caring and patience. I never would have made it without them.

My wife, Karyn, has been the source of my determination as well as the most loving, supportive and understanding person imaginable. To her, I say thank you.

Finally, the financial support of the Department of Chemistry and the National Institutes of Health is gratefully acknowledged. 


\section{Table of Contents}

$\begin{array}{ll}\text { Title Page } & \text { i }\end{array}$

$\begin{array}{ll}\text { Abstract } & \text { ii }\end{array}$

$\begin{array}{ll}\text { Acknowledgements } & \text { iii }\end{array}$

Table of Contents $\quad$ iv

List of Figures vii

List of Schemes $\quad$ X

List of Tables $\quad$ xii

\section{Part I}

Synthesis of Methyl Indole-4-carboxylate by Reductive $N$-Heteroannulation of Methyl 2-Ethenyl-3-nitrobenzoate

1. Introduction 1

1.1. Palladium-Catalyzed Indole Syntheses 3

2. Results and Discussion $\quad 5$

3. Conclusions $\quad 6$ 


\section{Part II}

Synthesis of Quinoxalines and 2-Quinoxalinones by Palladium-Catalyzed $N$ -

\section{Heteroannulation Reactions}

1. Introduction

2. Results and Discussion

3. Conclusions

\section{Part III}

Investigation into the Mechanism of the Palladium-Catalyzed $\mathrm{N}$ -

\section{Heteroannulation Reactions}

\section{Part IV}

\section{Novel Synthesis of 2-Alkylbenzimidazoles}

1. Introduction

2. Results and Discussion

3. Conclusions 


\section{Part V}

\section{Synthesis of Other Heterocyclic Ring Systems via $\mathbf{N}$-Heteroannulation Reactions}

1. Synthesis of Alloxazines 63

2. Synthesis of an Indole-fused Pyrimidine Derivative 68

$\begin{array}{ll}\text { 3. Conclusions } & 70\end{array}$

\section{Part VI}

\section{Experimental Section}

$\begin{array}{ll}\text { 1. General Procedures } & 72\end{array}$

$\begin{array}{ll}\text { 2. Experimental Details } & 73\end{array}$

$\begin{array}{ll}\text { References } & 118\end{array}$

$\begin{array}{ll}\text { Appendix } & 124\end{array}$

Approval of Examining Committee $\quad 219$ 


\section{List of Figures}

Figure 1: Strychnine and Sumatriptan (Imitrex) 1

Figure 2: Riboflavine and Oxythioquinox $\quad 7$

Figure 3: Omeprazole and Thiabendazole $\quad 46$

Figure 4: Alloxazine and Riboflavine $\quad 63$

Figure 5: General Structure of an Alloxazine Precursor $\quad 64$

Figure 6: General Structure of an Indole-fused Pyrimidine Derivative $\quad 69$

Figure 7: ${ }^{1} \mathrm{H}$ NMR of Compound $56 \quad 125$

Figure 8: ${ }^{13} \mathrm{C}$ NMR of Compound $56 \quad 126$

Figure 9: ${ }^{1} \mathrm{H}$ NMR of Compound 60

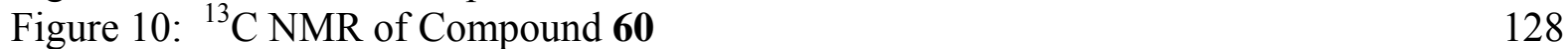

Figure 11: ${ }^{1} \mathrm{H}$ NMR of Compound 62

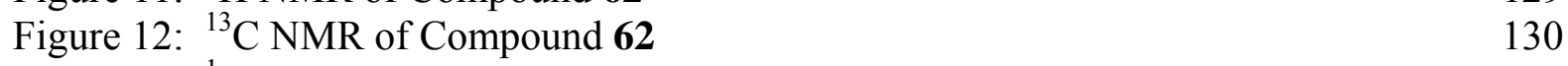

Figure 13: ${ }^{1} \mathrm{H}$ NMR of Compound 64

Figure 14: ${ }^{13} \mathrm{C}$ NMR of Compound 64

Figure 15: ${ }^{1} \mathrm{H}$ NMR of Compound $\mathbf{6 6}$

Figure 16: ${ }^{13} \mathrm{C}$ NMR of Compound $66 \quad 134$

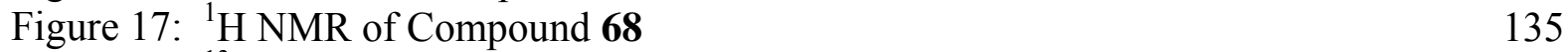

Figure 18: ${ }^{13} \mathrm{C}$ NMR of Compound 68

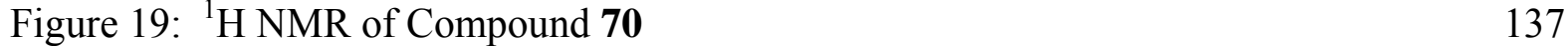

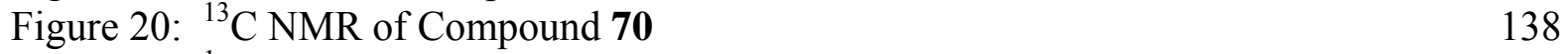

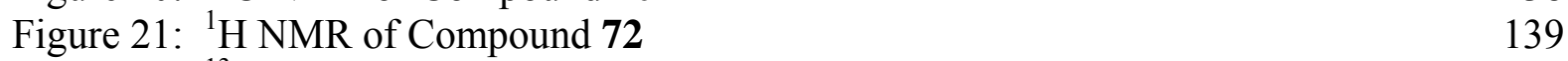

Figure 22: ${ }^{13} \mathrm{C}$ NMR of Compound $72 \quad 140$

Figure 23: ${ }^{1} \mathrm{H}$ NMR of Compound 74 141

Figure 24: ${ }^{13} \mathrm{C}$ NMR of Compound 74

Figure 25: ${ }^{1} \mathrm{H}$ NMR of Compound 76

Figure 26: ${ }^{13} \mathrm{C}$ NMR of Compound $76 \quad 144$

Figure 27: ${ }^{1} \mathrm{H}$ NMR of Compound 78

Figure 28: ${ }^{13} \mathrm{C}$ NMR of Compound $78 \quad 146$

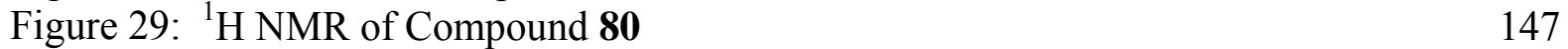

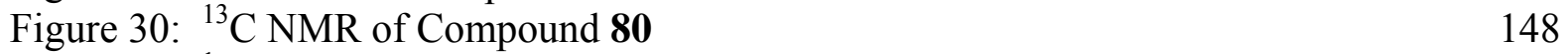

Figure 31: ${ }^{1} \mathrm{H}$ NMR of Compound 82-Z 149

Figure 32: ${ }^{13} \mathrm{C}$ NMR of Compound 82-Z 150

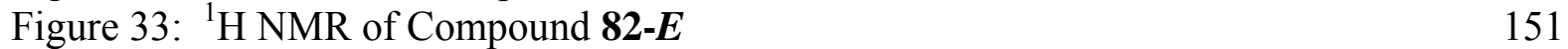

Figure 34: ${ }^{1} \mathrm{H}$ NMR of Compound 87

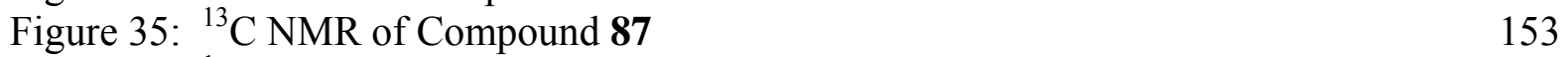

Figure 36: ${ }^{1} \mathrm{H}$ NMR of Compound 88

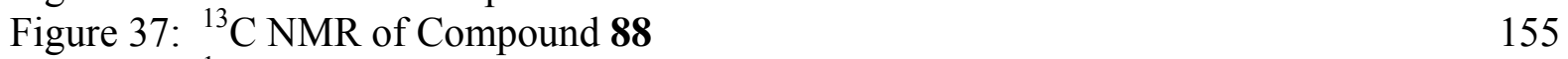

Figure 38: ${ }^{1} \mathrm{H}$ NMR of Compound 90

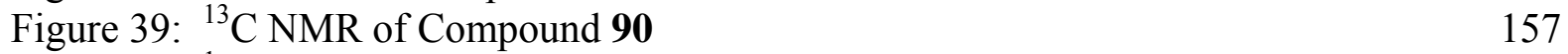

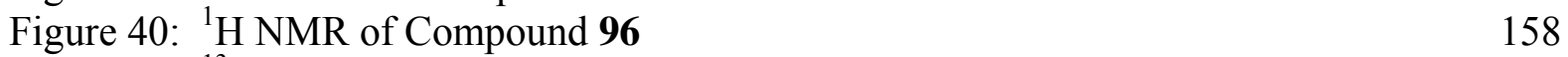

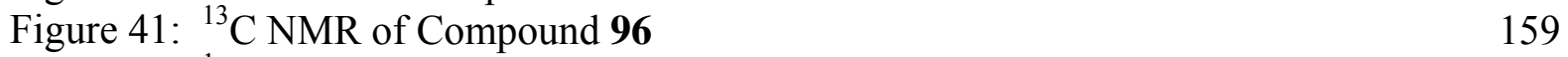

Figure 42: ${ }^{1} \mathrm{H}$ NMR of Compound $97 \quad 160$ 
Figure 43: ${ }^{13} \mathrm{C}$ NMR of Compound 97

Figure 44: ${ }^{1} \mathrm{H}$ NMR of Compound 98

Figure 45: ${ }^{13} \mathrm{C}$ NMR of Compound 98

Figure 46: ${ }^{1} \mathrm{H}$ NMR of Compound $\mathbf{1 0 0}$

Figure 47: ${ }^{13} \mathrm{C}$ NMR of Compound 100

Figure 48: ${ }^{1} \mathrm{H}$ NMR of Compound $\mathbf{1 0 2}$

Figure 49: ${ }^{13} \mathrm{C}$ NMR of Compound 102

Figure 50: ${ }^{1} \mathrm{H}$ NMR of Compound 104

Figure 51: ${ }^{13} \mathrm{C}$ NMR of Compound 104

Figure 52: ${ }^{1} \mathrm{H}$ NMR of Compound 106

Figure 53: ${ }^{13} \mathrm{C}$ NMR of Compound 106

Figure 54: ${ }^{1} \mathrm{H}$ NMR of Compound 108

Figure 55: ${ }^{13} \mathrm{C}$ NMR of Compound 108

Figure 56: ${ }^{1} \mathrm{H}$ NMR of Compound $\mathbf{1 1 0}$

Figure 57: ${ }^{13} \mathrm{C}$ NMR of Compound $\mathbf{1 1 0}$

Figure 58: ${ }^{1} \mathrm{H}$ NMR of Compounds $\mathbf{1 1 1}$ and 112

Figure 59: ${ }^{1} \mathrm{H}$ NMR of Compound 113

Figure 60: ${ }^{13} \mathrm{C}$ NMR of Compound 113

Figure 61: ${ }^{1} \mathrm{H}$ NMR of Compound 114

Figure 62: ${ }^{13} \mathrm{C}$ NMR of Compound 114

Figure 63: ${ }^{1} \mathrm{H}$ NMR of Compound 115

Figure 64: ${ }^{13} \mathrm{C}$ NMR of Compound 115

Figure 65: ${ }^{1} \mathrm{H}$ NMR of Compound $\mathbf{1 1 8}$

Figure 66: ${ }^{13} \mathrm{C}$ NMR of Compound $\mathbf{1 1 8}$

Figure 67: ${ }^{1} \mathrm{H}$ NMR of Compound 119

Figure 68: ${ }^{13} \mathrm{C}$ NMR of Compound 119

Figure 69: ${ }^{1} \mathrm{H}$ NMR of Compound 123

Figure 70: ${ }^{13} \mathrm{C}$ NMR of Compound 123

Figure 71: ${ }^{1} \mathrm{H}$ NMR of Compounds 124 and 125

Figure 72: ${ }^{13} \mathrm{C}$ NMR of Compounds 124 and 125

Figure 73: ${ }^{1} \mathrm{H}$ NMR of Compound 132

Figure 74: ${ }^{13} \mathrm{C}$ NMR of Compound 132

Figure 76: ${ }^{13} \mathrm{C}$ NMR of Compound 133

Figure 77: ${ }^{1} \mathrm{H}$ NMR of Compound 153

Figure 78: ${ }^{13} \mathrm{C}$ NMR of Compound 153

Figure 80: ${ }^{13} \mathrm{C}$ NMR of Compound 154

Figure 82: ${ }^{13} \mathrm{C}$ NMR of Compound 190

Figure 83: ${ }^{1} \mathrm{H}$ NMR of Compound 193

Figure 84: ${ }^{13} \mathrm{C}$ NMR of Compound 193 
Figure 89: ${ }^{1} \mathrm{H}$ NMR of Compound 196

Figure 90: ${ }^{13} \mathrm{C}$ NMR of Compound 196

Figure 91: ${ }^{1} \mathrm{H}$ NMR of Compound 198

Figure 92: ${ }^{13} \mathrm{C}$ NMR of Compound 198

Figure 93: ${ }^{1} \mathrm{H}$ NMR of Compound 199

Figure 94: ${ }^{13} \mathrm{C}$ NMR of Compound 199

Figure 95: ${ }^{1} \mathrm{H}$ NMR of Compound 217

Figure 96: ${ }^{13} \mathrm{C}$ NMR of Compound 217

Figure 97: ${ }^{1} \mathrm{H}$ NMR of Compound 226

Figure 98: ${ }^{13} \mathrm{C}$ NMR of Compound 226

Figure 99: ${ }^{1} \mathrm{H}$ NMR of Compound 228

217

Figure 100: ${ }^{13} \mathrm{C}$ NMR of Compound 228 


\section{List of Schemes}

Scheme 1: Fischer Indole Synthesis $\quad 2$

Scheme 2: Madelung Indole Synthesis $\quad 2$

Scheme 3: Bischler Indole Synthesis $\quad 3$

Scheme 4: Palladium-catalyzed Cyclization of 2-Nitrostyrenes 3

Scheme 5: Palladium-catalyzed Cyclization of 2-Allylaminobenzenes 4

Scheme 6: Palladium-catalyzed Cyclization of 2-Alkynylanilides 4

Scheme 7: Synthesis of Methyl Indole-4-carboxylate (21) 6

Scheme 8: The Work of Katoh et al $\quad 8$

Scheme 9: The Work of Ammar et al $\quad 8$

Scheme 10: The Work of Paglietti et al 9

Scheme 11: The Work of Kano et al $\quad 10$

Scheme 12: The Work of McKillop et al 11

Scheme 13: The Work of Iwanami 11

Scheme 14: The Work of Makino et al 12

Scheme 15: The Work of Krchňák et al 12

Scheme 16: The Work of Kobayashi et al 13

Scheme 17: The Work of Kundu et al $\quad 13$

Scheme 18: Synthesis of 54 and Cyclization Attempt 14

Scheme 19: Novel Synthesis of Quinoxalines and 2-Quinoxalinones 15

Scheme 20: Curtius Rearrangement of 3-Methyl-2-nitrobenzoic Acid 20

Scheme 21: Esterification of 4-Amino-3-nitrobenzoic Acid 20

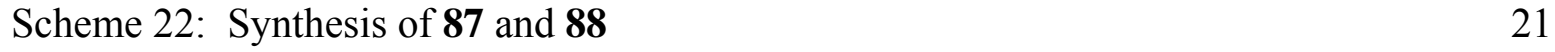

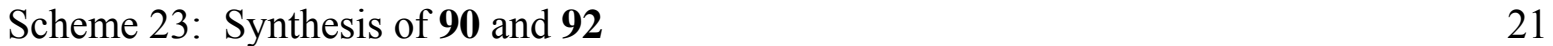

Scheme 24: Addition Elimination Reactions $\quad 22$

Scheme 25: Cyclization of $\mathbf{9 0}$ and Aromatization of $\mathbf{1 2 2} 27$

Scheme 26: Cyclization of $92 \quad 28$

Scheme 27: Synthesis of Acetylquinoxalines $\quad 29$

Scheme 28: Formation of Isomeric Nitrenes $\quad 30$

Scheme 29: Synthesis of 132, 133 and $\mathbf{1 3 4} 31$

Scheme 30: Synthesis of 67, 106 and $136 \quad 32$

Scheme 31: Preparation of Azides 131 and 135

Scheme 32: Cyclization Reactions under Various CO Pressures 33

Scheme 33: Cyclization Reactions with Various Reaction Times 34

Scheme 34: Cyclization Reactions with Various Solvent Mixtures 36

Scheme 35: Cyclization Reactions with the Addition of Excess Water 37

Scheme 36: Proposed Mechanism for the Formation of a Palladium-bound Nitrene 38

Scheme 37: Proposed Mechanism for the Formation of Quinoxalines 39

Scheme 38: Proposed Mechanism for the Formation of 2-Quinoxalinones 40

Scheme 39: Reaction of $\mathbf{1 0 2}$ and $\mathbf{1 0 5}$ under Cyclization Conditions 41

Scheme 40: Synthesis of Benzimidazole 151

Scheme 41: Preparation of 153

Scheme 42: Synthesis of $\mathbf{1 2 4}$ and $\mathbf{1 2 5}$ 
Scheme 43: Synthesis of $\mathbf{1 5 4}$

Scheme 44: Illustration of $\mathbf{1 4 0}$ as an Aryl Nitroso Group 45

Scheme 45: Reaction of 2-Nitrosoaminobenzene with 2-Methylpropanal 45

Scheme 46: The Work of Bárzana et al 47

Scheme 47: The Work of Grenda et al 48

Scheme 48: The Work of Li et al 449

Scheme 49: The Work of Perry et al 49

Scheme 50: The Work of Thomas et al $\quad 50$

Scheme 51: The Work of Cohen et al $\quad 51$

Scheme 52: The Work of Cenini et al 51

Scheme 53: The Work of Cadogan et al $\quad 52$

Scheme 54: The Work of Hall et al 53

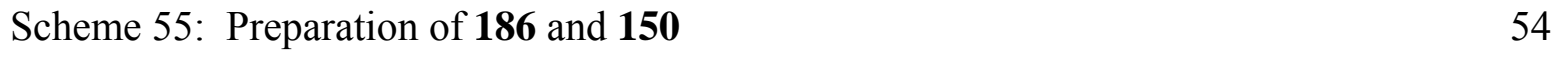

Scheme 56: Preparation of 152, 197 and $198 \quad 56$

Scheme 57: Proposed Mechanism for the Formation of Benzimidazoles 61

Scheme 58: Synthesis of $217 \quad 62$

Scheme 59: General Reaction of 2-Nitroaminobenzene and 6-Halouracils 65

Scheme 60: General Palladium-catalyzed Reactions to Form Cyclization Precursors 66

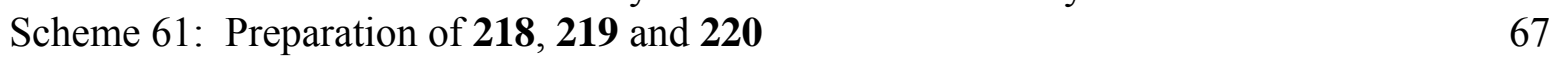

Scheme 62: Other Reactions to Form Cyclization Precursors 68

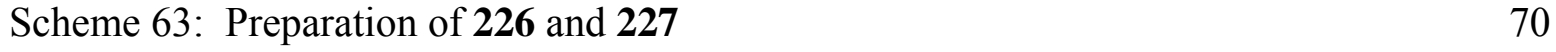

$\begin{array}{ll}\text { Scheme 64: Synthesis of } 228 & 70\end{array}$ 


\section{List of Tables}

Table 1: Synthesis of Enamines by Condensation Reactions $\quad 17$

Table 2: Synthesis of Quinoxalines and 2-Quinoxalinones $\quad 24$

Table 3: Results of Cyclization Reactions under Various CO Pressures 34

Table 4: Results of Cyclization Reactions with Various Reaction Times 35

Table 5: Results of Cyclization Reactions with Various Solvent Mixtures 36

Table 6: Synthesis of 2-Alkylbenzimidazoles $\quad 58$

Table 7: Conditions for the Reactions of 2-Nitroaminobenzene and 6-Halouracils 65

Table 8: Conditions for the Palladium-catalyzed Reactions 66 


\section{Part I}

\section{Synthesis of Methyl Indole-4-carboxylate by Reductive $N$-Heteroannulation of Methyl 2-Ethenyl-3-nitrobenzoate}

\section{Introduction}

The indole ring system can be found in many physiologically active compounds both naturally occurring and non-naturally occurring. Two of the more well known biologically active indoles are strychnine, a potent toxin, and sumatriptan, an antimigraine medicine marketed by GlaxoSmithKline under the name Imitrex (Figure 1). Other indole-containing compounds exhibit biological properties including antibacterial, ${ }^{1}$ antiallergy ${ }^{2}$ and antitumor ${ }^{3}$ activity. The development of synthetic routes to indoles is therefore a worthwhile goal of researchers.

\section{Figure 1. Strychnine and Sumatriptan (Imitrex)}

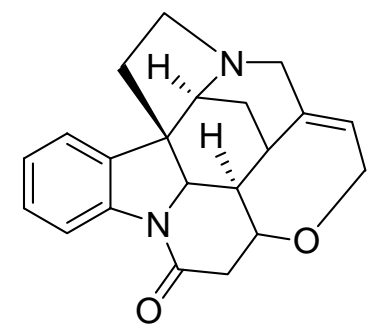

strychnine<smiles>CNS(=O)(=O)Cc1ccc2[nH]cc(CCN(C)C)c2c1</smiles>

sumatriptan (Imitrex)

One of the more commonly known routes is the Fischer indole synthesis (Scheme 1). ${ }^{4}$

This method involves the reaction of an arylhydrazine (1) and a ketone (2) to form an arylhydrazone (3) which is then treated with a Lewis acid such as $\mathrm{ZnCl}_{2}$ to form the indole (4). A potential drawback of the Fischer method is if the substrate contains an unsymmetrically 
substituted aryl ring, the reaction could lead to regioisomers. The potential for regioisomers also exists if some unsymmetrical ketones are used.

\section{Scheme 1. Fischer Indole Synthesis}

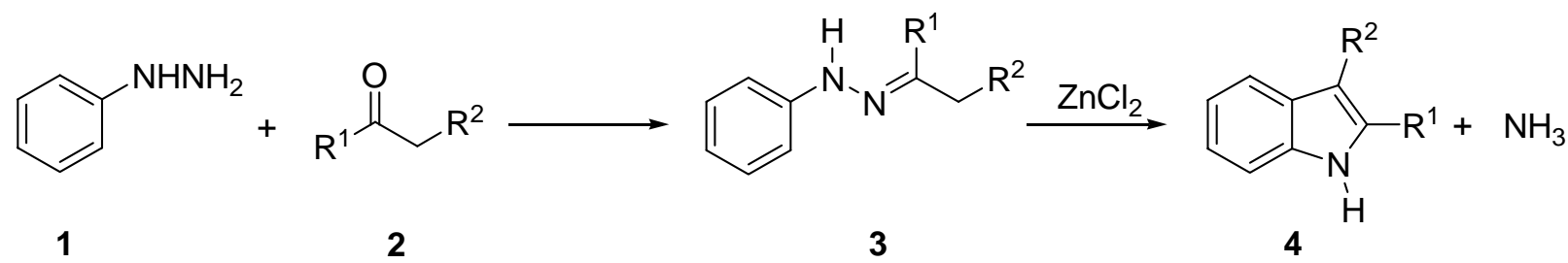

Another named route to indoles is the Madelung synthesis (Scheme 2). ${ }^{5}$ In this method, 2-tolylacetamide (5) is treated with base to form the benzyl carbanion, which then reacts with the carbonyl and, upon elimination, forms the indole (6). A strong base, such as an alkyllithium, is usually required for this reaction making it unsuitable for molecules with certain functional groups.

Scheme 2. Madelung Indole Synthesis

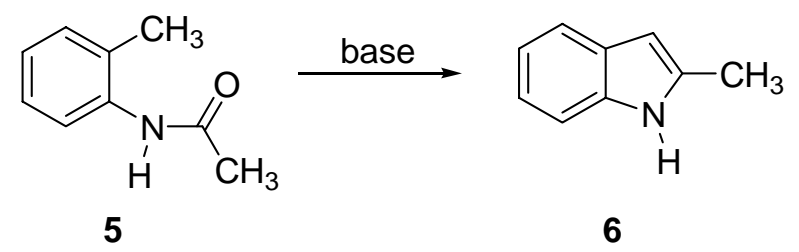

The Bischler method of indole preparation ${ }^{6}$ involves the reaction of aminobenzenes (7) with $\alpha$-haloketones $(\mathbf{8})$ to form $\alpha$-( $N$-arylamino)ketones (9) which are then cyclized in the 
presence of an acid catalyst to form the corresponding indoles (10) (Scheme 3). Just as with the Fischer method, regiochemistry becomes a problem with substrates containing unsymmetrically substituted aryl rings.

Scheme 3. Bischler Indole Synthesis

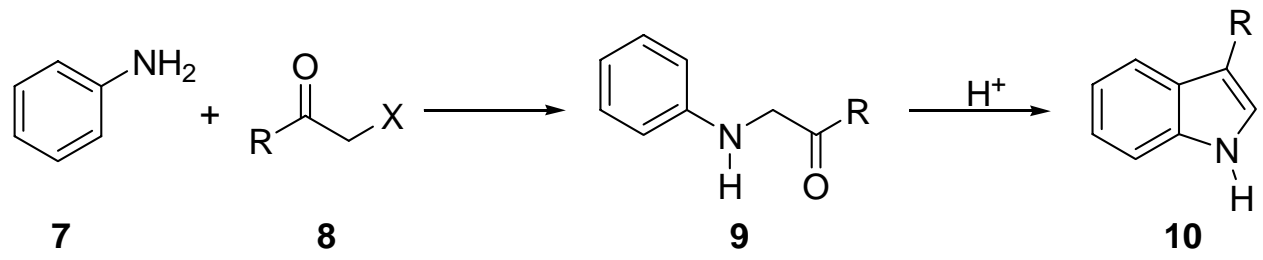

\subsection{Palladium-Catalyzed Indole Syntheses}

Recently, a new method for the preparation of indoles was developed in our group. ${ }^{7}$ This procedure, detailed in Scheme 4, involved the reductive $N$-heteroannulation of 2-nitrostyrenes (11) in the presence of a palladium catalyst, a phosphine and carbon monoxide to give indoles (12) in good yields. With no strong acid or base required in this reaction and no regiochemical issues, this method is potentially more useful than many others.

\section{Scheme 4. Palladium-catalyzed Cyclization of 2-Nitrostyrenes}<smiles>C=Cc1ccccc1[N+](=O)[O-]</smiles>

11

$$
\begin{gathered}
\frac{\mathrm{Pd}(\mathrm{OAc})_{2}, \mathrm{PPh}_{3}}{\mathrm{CO}(4 \mathrm{~atm}), 70^{\circ} \mathrm{C}} \\
\mathrm{CH}_{3} \mathrm{CN}
\end{gathered}
$$

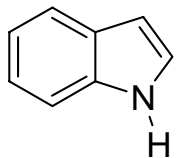

12 (87\%) 
Other palladium-catalyzed routes to indoles include the reaction of 2-allylaminobenzenes (13) with $\mathrm{PdCl}_{2}\left(\mathrm{CH}_{3} \mathrm{CN}\right)_{2}$ as the catalyst and benzoquinone as the reoxidant to give indoles (14) generally in good yields (Scheme 5). ${ }^{8}$

\section{Scheme 5. Palladium-catalyzed Cyclization of 2-Allylaminobenzenes}

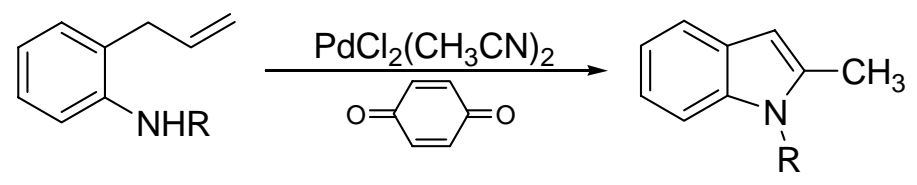

13

14

In addition to the reactions of alkenes, some methods have been developed that involve the cyclization of arylalkynes. One such method uses $\mathrm{PdCl}_{2}\left(\mathrm{CH}_{3} \mathrm{CN}\right)_{2}$ as a catalyst to convert 2alkynylanilides (15) to $N$-acylated indoles ${ }^{9}(\mathbf{1 6})$ as described in Scheme 6.

\section{Scheme 6. Palladium-catalyzed Cyclization of 2-Alkynylanilides}

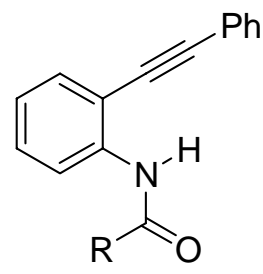

15

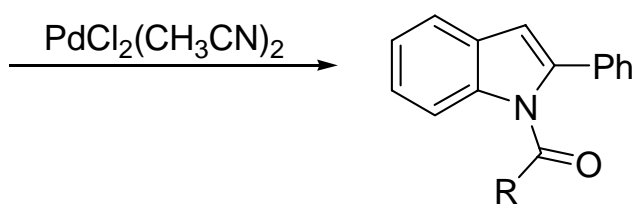

16

Most of the indole-forming reactions of the type described in Scheme 4 were performed on a relatively small scale $(1-2 \mathrm{mmol})$ in a glass pressure tube $(20-40 \mathrm{~mL})$. We wanted to know if it was feasible to produce indoles on a larger scale $(20-50 \mathrm{mmol})$ using our method and so a 
scaled-up procedure was developed. That procedure was used to synthesize methyl indole-4carboxylate and it is presented.

\section{Results and Discussion}

The synthesis of methyl indole-4-carboxylate is detailed in Scheme 7. Methyl 2-methyl3-nitrobenzoate (17) was previously synthesized in our laboratory according to a literature procedure. ${ }^{10}$ Compound $\mathbf{1 8}$ was prepared easily from $\mathbf{1 7}$ via radical bromination. The bromide was transformed into triphenylphosphonium bromide 19 by reaction with triphenylphosphine. Treatment with triethylamine formed the ylide necessary for the subsequent Wittig reaction with formaldehyde to form $\mathbf{2 0}$ in $71 \%$ from bromide $\mathbf{1 8}$. Because of the increased scale of the reaction and to avoid the explosion of a smaller glass pressure vessel (the pressure we used was approaching the upper limit of the manufacturer rating), it was necessary to use a large stainless

steel high pressure Parr reactor for the conversion of $\mathbf{2 0}$ to $\mathbf{2 1}$. The reaction of $\mathbf{2 0}(4.10 \mathrm{~g}, 20.00$ $\mathrm{mmol})$ in the presence of $\mathrm{Pd}(\mathrm{OAc})_{2}(269 \mathrm{mg}, 1.2 \mathrm{mmol})$, triphenylphosphine $(1.30 \mathrm{~g}, 4.8 \mathrm{mmol})$ and $\mathrm{CO}(6 \mathrm{~atm})$ at $90^{\circ} \mathrm{C}$ in acetonitrile $(100 \mathrm{~mL})$ for $27 \mathrm{~h}$ gave methyl indole-4-carboxylate (21) (3.06 g, $17.5 \mathrm{mmol})$ in $87 \%$ yield. 
Scheme 7. Synthesis of Methyl Indole-4-carboxylate (21)<smiles>COC(=O)c1cccc([N+](=O)[O-])c1C</smiles>

17<smiles>COC(=O)c1cccc([N+](=O)[O-])c1CBr</smiles>

$18(100 \%)$
19

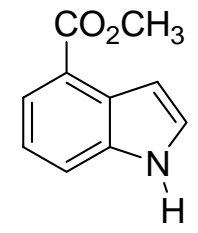

$21(87 \%)$

\section{Conclusions}

We have developed a mild and efficient multi-mmol synthesis of methyl indole-4-

carboxylate. The key step of this synthetic route is the reductive $N$-heteroannulation of methyl 2ethenyl-3-nitrobenzoate using a protocol previously developed in our laboratory. 


\section{Part II}

\section{Synthesis of Quinoxalines and 2-Quinoxalinones by Palladium-Catalyzed $N$ - Heteroannulation Reactions}

\section{Introduction}

The quinoxaline structure is a moiety found in many compounds exhibiting biological activity. Examples of biologically active quinoxalines are riboflavine, also known as vitamin $\mathrm{B}_{2}$, an important nutritional factor, and oxythioquinox, an antifungal agent (Figure 2). Other quinoxalines exhibit antifungal, ${ }^{11}$ antituberculosis, ${ }^{12}$ antiepilepsy, ${ }^{13}$ antibacterial $1{ }^{14}$ and antitumor ${ }^{15}$ activities. This wide range of physiological activity makes the quinoxaline ring system an attractive synthetic target.

\section{Figure 2. Riboflavine and Oxythioquinox}<smiles>Cc1cc2nc3c(=O)[nH]c(=O)nc-3n(CC(C)(O)C(O)C(C)O)c2cc1C</smiles>

riboflavine<smiles>Cc1ccc2nc3sc(=O)sc3nc2c1</smiles>

oxythioquinox

Most previous syntheses of quinoxalines involve the Hinsberg condensation of substituted 1,2-diaminobenzenes with 1,2-dicarbonyl compounds. This method generally resulted in the formation of isomeric products from unsymmetrical starting materials. Katoh et 
al reported the synthesis of quinoxalines 24 and 25 by the reaction of methyl 3,4diaminobenzoate (22) and ethyl pyruvate (23) (Scheme 8). ${ }^{16}$ The products were obtained in $87 \%$ as a 1:1 mixture of regioisomers.

\section{Scheme 8. The Work of Katoh et al}<smiles>COC(=O)c1ccc(N)c(N)c1</smiles>

It is possible, however, to achieve some degree of selectivity in the production of regioisomers if the nucleophilicity of the amino groups or the electrophilicity of the carbonyls is sufficiently different. Ammar et al described the formation of quinoxalines $\mathbf{2 8}$ and $\mathbf{2 9}$ as a 2:1 mixture from 4-benzoyl-1,2-diaminobenzene (26) and pyruvic acid (27) (Scheme 9). ${ }^{17}$ In this case the benzoyl moiety deactivates the para-amino group leaving the meta-amino group to react with the more reactive ketone to form $\mathbf{2 8}$ as the major isomer.

\section{Scheme 9. The Work of Ammar et al}<smiles>CC(=O)C(=O)OC(=O)C(C)(C)C(=O)c1ccc2nc(O)c(C)nc2c1</smiles> 
It is also possible to utilize substituent effects and reaction conditions simultaneously to achieve selectivity. The work of Paglietti et al is detailed in Scheme 10. In this example, substituted 1,2-diaminobenzenes (30) are reacted with phenyl glyoxal (31) to form quinoxalines

$\mathbf{3 2}$ and $\mathbf{3 3}$ in different ratios if the reaction was performed in neutral, acidic or basic conditions. ${ }^{18}$

\section{Scheme 10. The Work of Paglietti et al}

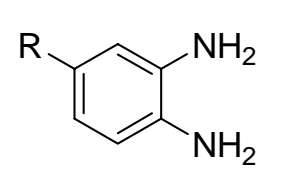

30<smiles>CCOC(=O)C=CC(=O)c1ccccc1</smiles>

31<smiles>[R]c1ccc2nc(-c3ccccc3)cnc2c1</smiles>

32<smiles>[R]c1ccc2ncc(-c3ccccc3)nc2c1</smiles>

33

$\begin{array}{cccc}\text { Conditions } & \underline{\mathbf{R}} & \text { yield } & \text { Ratio (32:33) } \\ \text { neutral } & \mathrm{OCH}_{3} & 59 \% & 1: 8 \\ \text { neutral } & \mathrm{NO}_{2} & 79 \% & 5: 1 \\ \text { acidic } & \mathrm{OCH}_{3} & 61 \% & 1.1: 1 \\ \text { acidic } & \mathrm{NO}_{2} & 79 \% & 5: 1 \\ \text { basic } & \mathrm{NO}_{2} & 84 \% & 1: 4\end{array}$

The Hinsberg-type condensation reactions of 1,2-diaminobenzenes with 1,2-

dielectrophiles are not limited to 1,2-dicarbonyl compounds. Kano et al reported the synthesis of quinoxalines $\mathbf{3 2}$ and $\mathbf{3 3}$ in 27-30\% yield from the condensation of substituted 1,2diaminobenzenes (30) and phenacyldimethylsulfonium iodide (34) (Scheme 11). ${ }^{19}$ Selectivity was achieved by using the appropriate substituents on the aryl ring. When the substituent was electron withdrawing, the para-amino group was deactivated and the meta-amino group reacted with the preferred $\alpha$-methylene carbon of the sulfonium salt to form only $\mathbf{3 2}$. Conversely, when 
the substituent was electron donating, the para-amino group reacted at this preferred site to form only 33.

\section{Scheme 11. The Work of Kano et al}

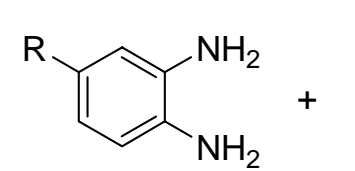

30<smiles>C[Sb](C)CC(=O)c1ccccc1</smiles>

34<smiles>[R]c1ccc2nc(-c3ccccc3)cnc2c1</smiles>

32<smiles>[R]c1ccc2ncc(-c3ccccc3)nc2c1</smiles>

33

$\begin{array}{cr}\underline{\mathbf{R}} & \text { Ratio (32: } \\ \mathrm{Cl} & 1: 2 \\ \mathrm{OCH}_{3} & \text { all 33 } \\ \mathrm{NO}_{2} & \text { all 32 }\end{array}$

McKillop et al reported the formation of aminoquinoxalines $\mathbf{3 6}$ and $\mathbf{3 7}$ from the reaction of substituted 1,2-diaminobenzenes (30) and ethyl carboethoxyformimidate (35) (Scheme 12). ${ }^{20}$ As in the previous examples, selectivity can be achieved in this reaction depending on the electronic nature of the substituent. 


\section{Scheme 12. The Work of McKillop et al}<smiles>[R]c1ccc(N)c(N)c1</smiles>

30<smiles>CCOC(=N)C(=O)OCC</smiles>

35

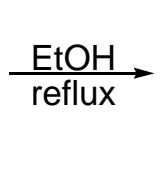

36<smiles>[R]c1ccc2nc(N)c(O)nc2c1</smiles><smiles>[R]c1ccc2nc(O)c(N)nc2c1</smiles>

37

R $\quad$ Ratio (36:37)

$\mathrm{CH}_{3}$

$1: 1$

$\mathrm{NO}_{2} \quad$ all 37

Other variations of the 1,2-dielectrophiles are acetylenedicarboxylates. Iwanami described the reaction of 1,2-diaminobenzene (38) with diethyl acetylenedicarboxylate (39) to form 40 in almost quantitative yield (Scheme 13). ${ }^{21}$ In this reaction, one amine reacts with an ester and the other amine is in position to react in a Michael-fashion. The yield of this reaction is good; however, the use of unsymmetrical starting materials would lead to the formation of regioisomers.

\section{Scheme 13. The Work of Iwanami}<smiles>Nc1ccccc1N</smiles>

38<smiles>CCOC(=O)C#CC(=O)OCC</smiles>

39<smiles>CCO</smiles><smiles>CCOC(=O)/C=C1/Nc2ccccc2NC1=O</smiles>

40 
Makino et al reported the reaction of 41 with diketene (42) to give $N$-oxide 43 in $70 \%$ yield. Subsequent reduction of $\mathbf{4 3}$ with sodium hydrogensulfite gives quinoxalinone $\mathbf{4 4}$ in $75 \%$ yield (Scheme 14). ${ }^{22}$

Scheme 14. The Work of Makino et al<smiles>O=[N+]([O-])c1cccc2c1NCCC2</smiles>

41<smiles>C=C1CC(=O)O1</smiles>

42<smiles></smiles>

$43(70 \%)$<smiles>O=c1cnc2cccc3c2n1CCC3</smiles>

$44(75 \%)$

Krchňák et al reported the synthesis of $\mathbf{4 6}$ on solid support via the reduction of $\mathbf{4 5}$ to the aryl amine and subsequent intramolecular reaction with the ester (Scheme 15). ${ }^{23}$ After cleavage of the solid support, $\mathbf{4 6}$ could be easily oxidized to the corresponding fully aromatic quinoxaline.

\section{Scheme 15. The Work of Krchňák et al}<smiles>[R]C(C(C)=O)N(C[O-])c1ccccc1[N+](=O)[O-]</smiles>

45

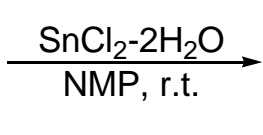

46 
Quinoxalines of type $\mathbf{4 9}$ have been synthesized in good to moderate yields by the reaction of 1-(2-isocyanophenyl)pyrrole (47) with Eschenmoser's salts (48), as reported by Kobayashi et al (Scheme 16). ${ }^{24}$

Scheme 16. The Work of Kobayashi et al

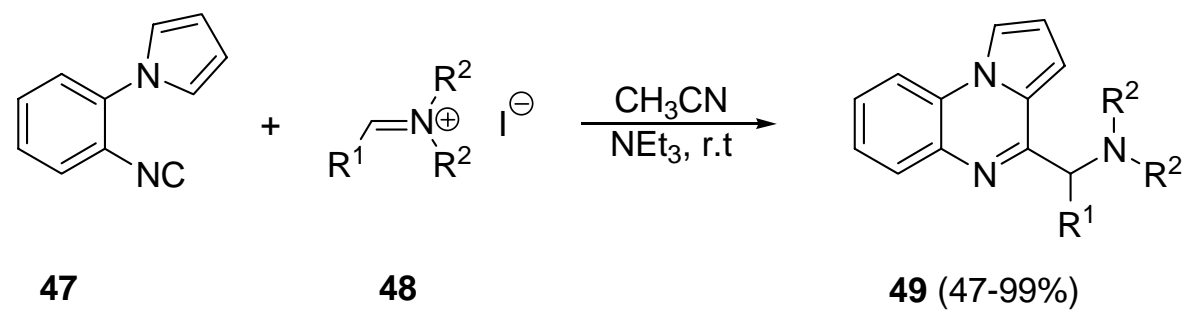

Kundu et al described the synthesis of 2-aroylquinoxalines (51) by the copper iodidecatalyzed cyclization of alkyne $\mathbf{5 0}$ (Scheme 17). ${ }^{25}$ The products are formed in moderate yields with the lowest yields reported when the aryl group on the alkyne contains an electron donating substituent in the para position (ex. $\left.\mathrm{Ar}=p-\mathrm{CH}_{3} \mathrm{O}-\mathrm{C}_{6} \mathrm{H}_{4}\right)$. This is presumably because the alkyne is more electron rich and, therefore, is a less favorable position for the amine to attack.

\section{Scheme 17. The Work of Kundu et al}<smiles>[AsH3]N(CC#CBr)c1ccccc1[AsH3-]</smiles>

50

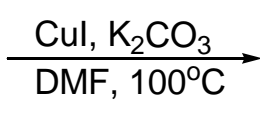

$51(40-60 \%)$<smiles>O=C(Br)c1cnc2ccccc2n1</smiles> 
There are many synthetic routes to the quinoxaline ring system; however, many of these methods have limitations. In most cases, regiochemistry is an issue unless one of only a few functional groups is used. Often another limitation is low yields. We have developed a synthetic method to quinoxalines and 2-quinoxalinones via $\mathrm{N}$-heteroannulation of $\mathrm{N}$-(2nitroaryl)enamines. Regioselectivity is not an issue in our method and a variety of functional groups are compatible with the reaction conditions. Also, our reactions typically proceeded smoothly in high conversion. The novel synthesis of an array of quinoxalines and 2quinoxalinones is presented.

\section{Results and Discussion}

Our initial goal was to utilize the aforementioned palladium-catalyzed cyclization conditions (Scheme 4) to prepare a series of benzimidazoles from a variety of imines (Scheme 18). Compound $\mathbf{5 4}$ was prepared in moderate yield from the condensation of 2nitroaminobenzene (52) and 4-nitrobenzaldehyde (53). The subsequent cyclization, however, failed. Even after numerous attempts to refine the cyclization conditions by employing $\operatorname{Pd}(\mathrm{dba})_{2}$ $(\mathrm{dba}=$ dibenzylideneacetone $), 1,3-$ bis(diphenylphosphino)propane (dppp) and $N, N$ dimethylformamide (DMF), the reactions were still met with no success.

\section{Scheme 18. Synthesis of 54 and Cyclization Attempt}

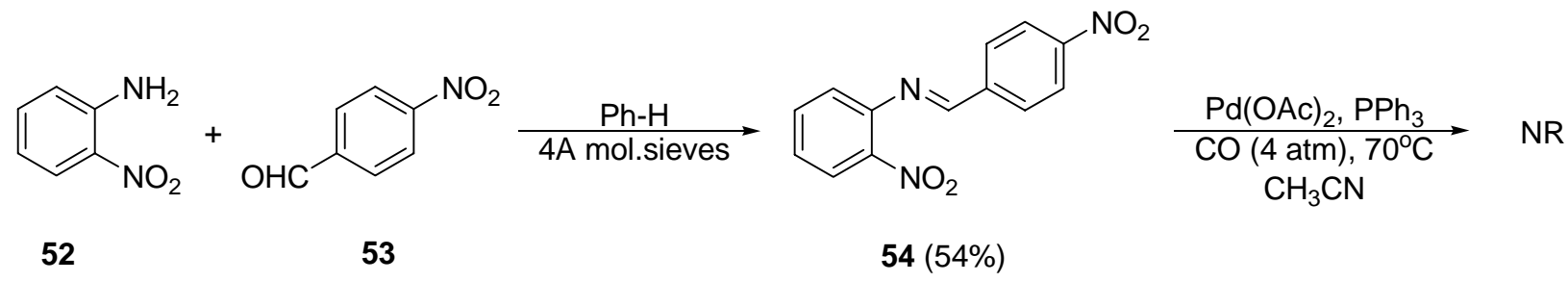


Next, we tried to prepare an aryl imine with an aliphatic substituent. However, the reaction of 2-nitroaminobenzene (52) and 2-methylpropanal (55) produced enamine 56 instead of the expected imine. Since the mechanism for the cyclization reaction is not well established, we decided to react 56 under $\mathrm{CO}$ atmosphere and in the presence of $\mathrm{Pd}(\mathrm{dba})_{2}$ and dppp in the hopes of getting the corresponding 2-isopropylbenzimidazole. Instead, this reaction afforded quinoxaline 57 and quinoxalinone 58 in 71\% and 11\%, respectively (Scheme 19).

\section{Scheme 19. Novel Synthesis of Quinoxalines and 2-Quinoxalinones}<smiles>CC(C)=CNc1ccccc1[N+](=O)[O-]</smiles>

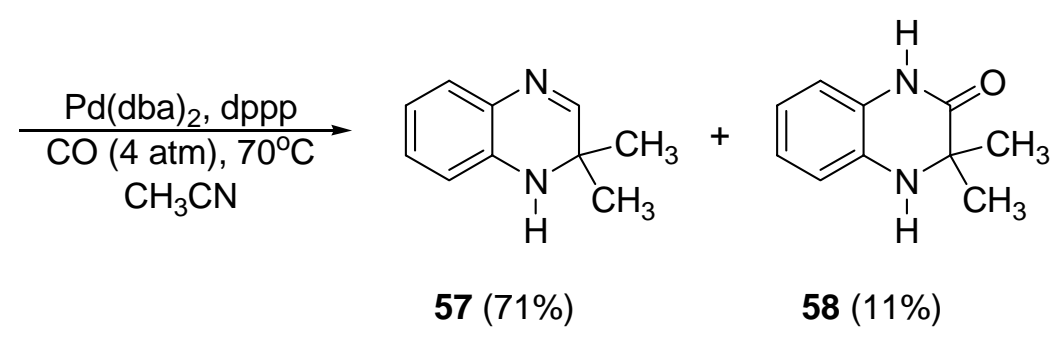

With this result in hand, we set out to determine the scope and limitations of this novel cyclization reaction. First, we needed to synthesize a variety of enamines as precursors to cyclization. Most of the enamines were prepared by the condensation of a commercially available substituted 2-nitroaminobenzene and an $\alpha, \alpha$-disubstituted aldehyde, most commonly 2- 
methylpropanal. Most of the reactions were carried out at ambient temperature under inert atmosphere in the presence of $4 \AA$ molecular sieves with benzene or $\mathrm{CH}_{2} \mathrm{Cl}_{2}$ as the solvent.

Table 1 shows the results of the condensation reactions. Some modifications of the reaction conditions were made for the synthesis of compounds 56,68 and 70 . Initially, for compound 56, the reaction mixture was cooled to $-20^{\circ} \mathrm{C}$ to avoid hydrolysis of the product. This reaction produced $\mathbf{5 6}$ in 73\% yield, but it was later determined that the cooling was unnecessary and it was abandoned on future reactions. The yields of compounds $\mathbf{6 8}$ and $\mathbf{7 0}$ were improved by heating the reaction mixture in a standard microwave oven. Compound $\mathbf{8 2}$ was isolated in $85 \%$ yield as an inseparable mixture of cis and trans isomers.

Generally, the condensation reactions produced the desired enamines in very good yields. The lower yield of $\mathbf{6 8}$ may be attributed to the increased steric bulk around the amino group. Also, slightly lower yields were obtained when the substituent on the aryl ring was an electron withdrawing group. This served to deactivate the amine and render it a much poorer nucleophile. By the same token, the nucleophilicity of the amine was increased when the substituent was an electron donating group, producing generally higher yields of enamines. It also seems that enamines from a 2-nitroaminobenzene and a straight-chain aliphatic aldehyde cannot be formed by this method. Starting material was recovered unchanged from the reaction of 52 and $\mathbf{8 3}$ (Table 1, Entry 14). 
Table 1. Synthesis of Enamines by Condensation Reactions

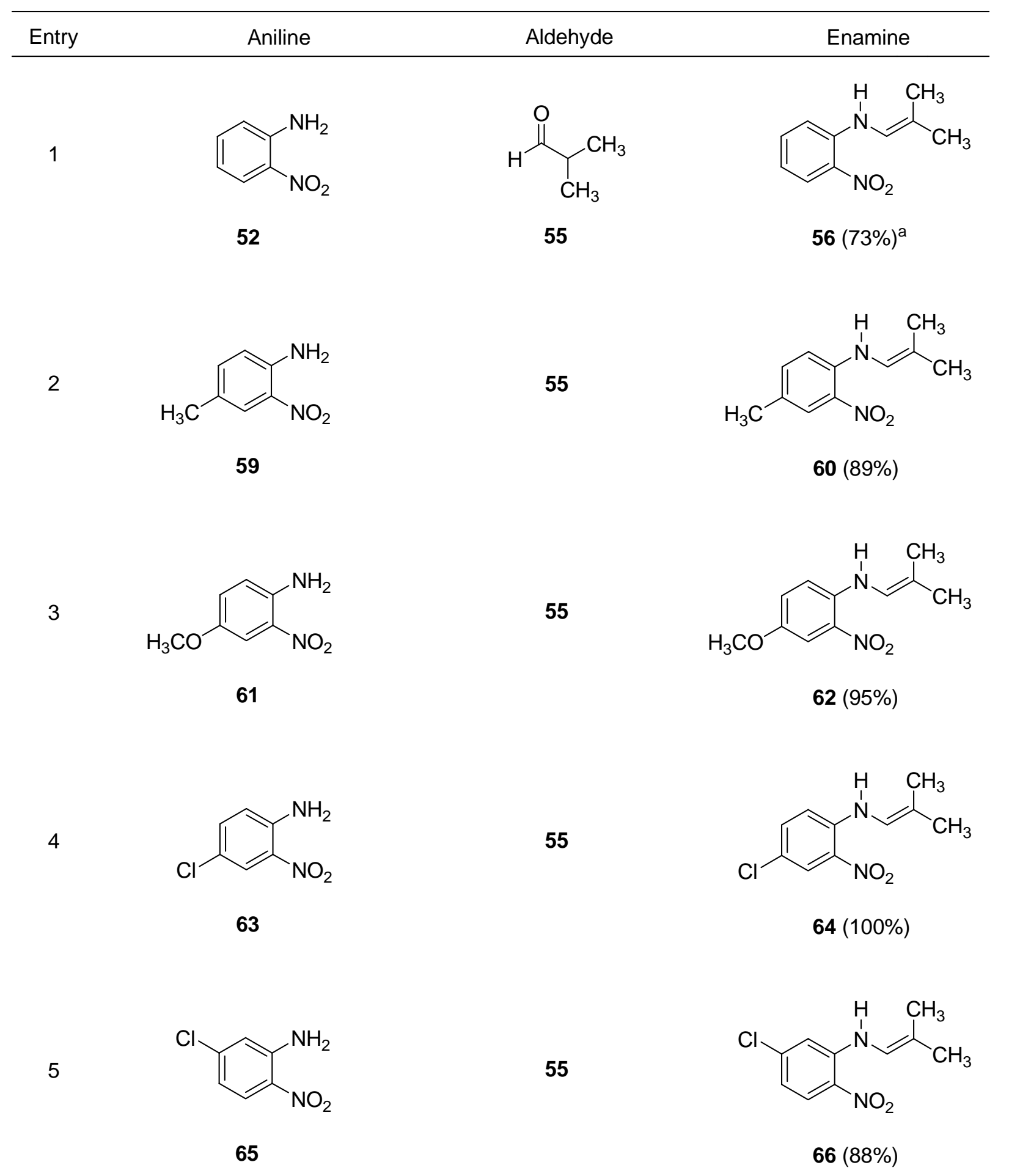




\section{Table 1 (continued)}

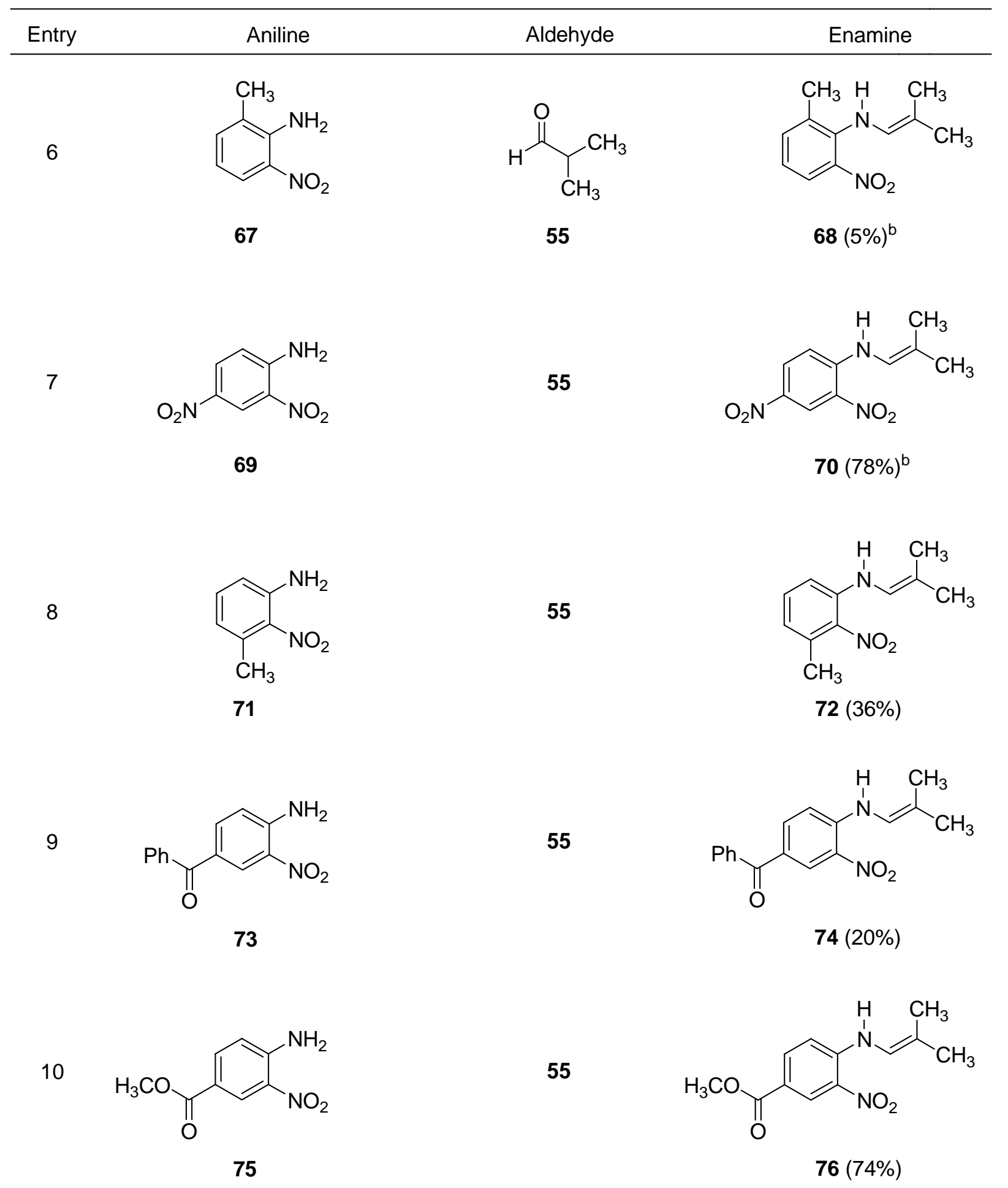




\section{Table 1 (continued)}

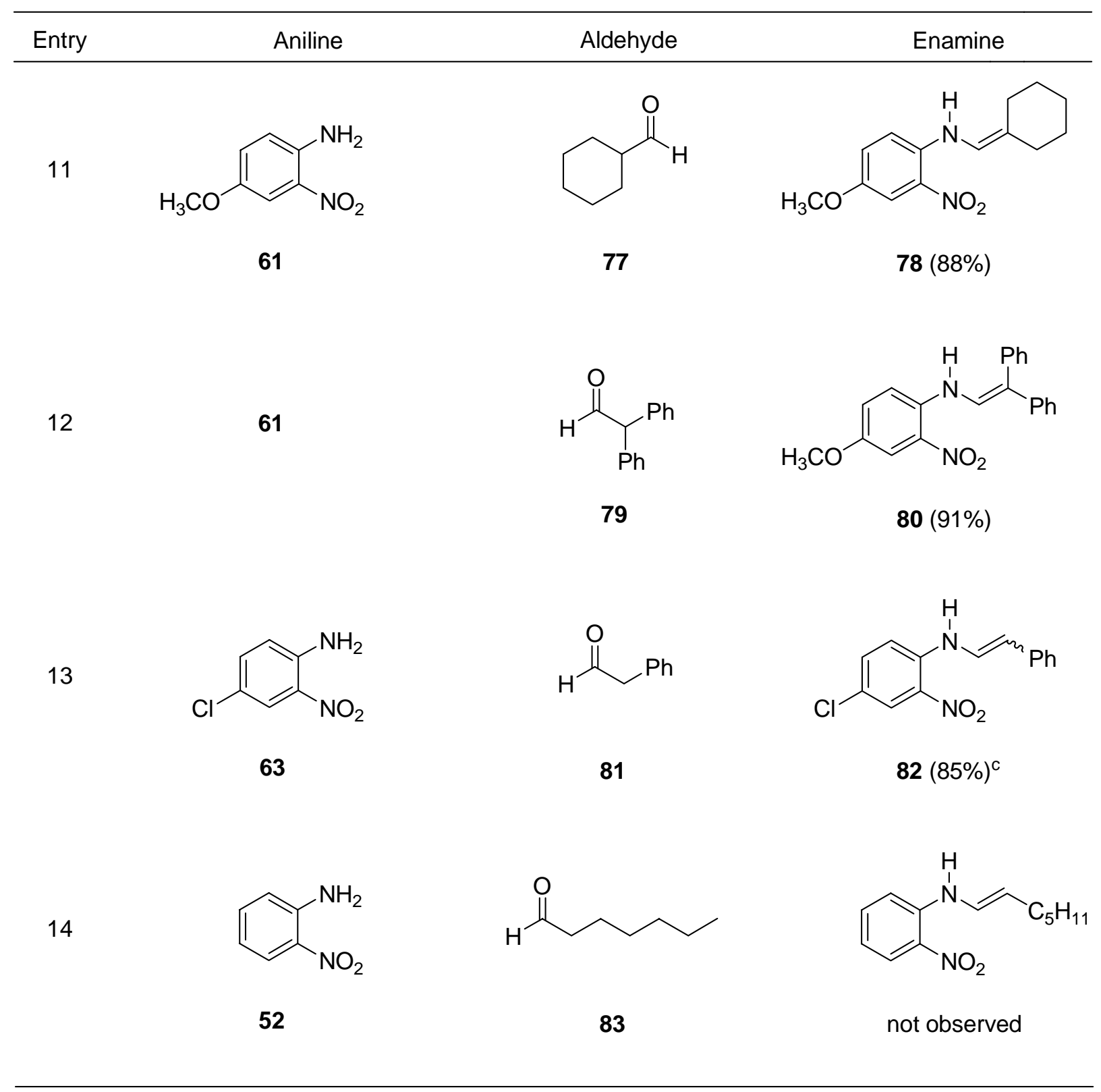

a) Reaction temperature was $-20^{\circ} \mathrm{C}$. b) Reactions were heated in a microwave oven. c) Product was isolated as a 1:1 mixture of cis and trans isomers.

Since compounds $\mathbf{7 1}$ and $\mathbf{7 5}$ are not commercially available, it was necessary to prepare them for the condensation reactions. Compound 71 was prepared via Curtius rearrangement of 
3-methyl-2-nitrobenzoic acid (84) (Scheme 20). Compound 75 was prepared by the acidpromoted esterification of 4-amino-3-nitrobenzoic acid (85) (Scheme 21).

\section{Scheme 20. Curtius Rearrangement of 3-Methyl-2-nitrobenzoic Acid}<smiles>Cc1cccc(C(=O)O)c1[N+](=O)[O-]</smiles>

84

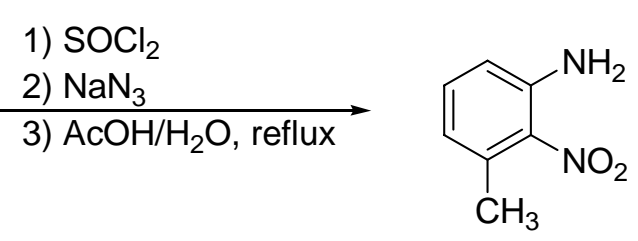

$71(60 \%)$

Scheme 21. Esterification of 4-Amino-3-nitrobenzoic Acid<smiles>Nc1ccc(C(=O)O)cc1[N+](=O)[O-]</smiles>

85

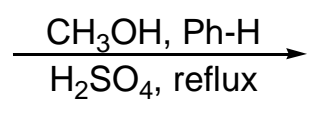<smiles>COC(=O)c1ccc(N)c([N+](=O)[O-])c1</smiles>

$75(69 \%)$

As well as pursuing substrates with a substituted aryl ring, we also synthesized an aryl enamine containing the pyridine moiety. Scheme 22 shows the condensation of 2-amino-3nitropyridine (86) and 2-methylpropanal (55). This reaction gave the desired compound 87, but in low yield. Another product of the reaction was compound $\mathbf{8 8}$, which resulted from the attack of a second amine on the imine intermediate. 


\section{Scheme 22. Synthesis of 87 and 88}<smiles>Nc1ncccc1[N+](=O)[O-]</smiles>

86<smiles>CC(C)C=O</smiles>

55

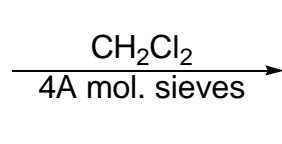<smiles>CC(C)=CNc1ncccc1[N+](=O)[O-]</smiles>

$87(20 \%)$<smiles>CC(C)C(Nc1ncccc1[N+](=O)[O-])Nc1ncccc1[N+](=O)[O-]</smiles>

$88(44 \%)$

In order to expand the scope of the methodology, we decided to synthesize enamines containing an $\alpha, \beta$-unsaturated carbonyl moiety. Scheme 23 details the preparation of two of these compounds. Compound 90 was prepared in $32 \%$ yield by the condensation of 2 nitroaminobenzene (52) and 1,2-cyclohexandione (89). Compound 92 was prepared in the same way in 70\% yield by the reaction of 2-nitroaminobenzene (52) and 1,3-cyclohexandione (91).

\section{Scheme 23. Synthesis of 90 and 92}<smiles>Nc1ccccc1[N+](=O)[O-]</smiles>

52<smiles>Nc1ccccc1[N+](=O)[O-]</smiles>

52<smiles>O=C1CCCCC1=O</smiles>

89<smiles>O=C1CCCC(=O)C1</smiles>

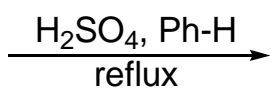
91

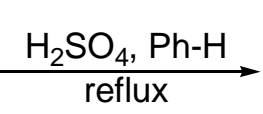<smiles>O=C1CCCC=C1Nc1ccccc1[N+](=O)[O-]</smiles>

$90(32 \%)$ 
The synthesis of compounds $\mathbf{9 5 , 9 6}$ and 97 is described in Scheme 24. The enamines were prepared via an addition-elimination reaction of the corresponding 2-nitroaminobenzene and (E)-4-methoxy-3-buten-2-one (94), which was prepared according to Neuenschwander's procedure. ${ }^{26}$ It is interesting to note that only the cis isomer in each case is formed. According to Fedor et al, the cis isomer is the thermodynamically more stable isomer when the possibility for hydrogen bonding exists between the carbonyl and amino groups. ${ }^{27}$ These reactions proceeded smoothly and afforded the desired products in high yields.

\section{Scheme 24. Addition Elimination Reactions}<smiles>[R]c1cc(N)c([N+](=O)[O-])cc1[R]</smiles>

$52 \mathrm{R}^{1}=\mathrm{R}^{2}=\mathrm{H}$ $59 \mathrm{R}^{1}=\mathrm{H}, \mathrm{R}^{2}=\mathrm{CH}_{3}$ $93 \mathrm{R}^{1}=\mathrm{CH}_{3}, \mathrm{R}^{2}=\mathrm{H}$<smiles>COC=CC(C)=O</smiles>

94

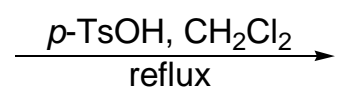<smiles>[R]c1ccc(NNc2cc(C)c([R])cc2[N+](=O)[O-])cc1[R]</smiles>

95 (98\%), $\mathrm{R}^{1}=\mathrm{R}^{2}=\mathrm{H}$ 96 (86\%), $\mathrm{R}^{1}=\mathrm{H}, \mathrm{R}^{2}=\mathrm{CH}_{3}$ 97 (71\%), $\mathrm{R}^{1}=\mathrm{CH}_{3}, \mathrm{R}^{2}=\mathrm{H}$

With the preparation of several enamines, we now could test the scope of the cyclization reaction. The first attempted cyclization of enamine 56 using $\operatorname{Pd}(\mathrm{dba})_{2}(6 \mathrm{~mol} \%)$, dppp (6 mol\%) and carbon monoxide (4 atm) in acetonitrile at $70{ }^{\circ} \mathrm{C}$ gave quinoxaline $\mathbf{5 7}$ and quinoxalinone 58 in $71 \%$ and $11 \%$, respectively (Scheme 19). Despite the success of this reaction, attempts to cyclize other enamines under the same conditions failed. With further refining of the reaction conditions, we found that the following worked the best: $\operatorname{Pd}(\mathrm{dba})_{2}(6 \mathrm{~mol} \%)$, dppp $(6 \mathrm{~mol} \%)$, 1,10-phenanthroline monohydrate (phen) (12 mol\%), CO (6 atm) in DMF at $70{ }^{\circ} \mathrm{C}$. 
We tested these reaction conditions on the substrates shown in Table 1. The results of these cyclizations are summarized in Table 2. Most of the reactions proceeded smoothly to give a mixture of quinoxalines and 2-quinoxalinones in high total yields. The cyclization of $\mathbf{6 2}$ gave compounds 100 and 101 in 76\% and 11\%, respectively. It is interesting to note that this reaction was performed again under seemingly identical conditions and the yields of $\mathbf{1 0 0}$ and $\mathbf{1 0 1}$ were $57 \%$ and $40 \%$, respectively. This result has since been irreproducible. Lower yields were typically seen in the cases that had an electron withdrawing group on the aryl ring; no evidence of either expected product was seen in the attempted cyclization of $\mathbf{7 0}$. The cyclization of $\mathbf{7 4}$ produced a product that was tentatively assigned as $\mathbf{1 1 0}$ (Table 2, Entry 9). Numerous attempts to purify compound $\mathbf{1 1 0}$ by column chromatography failed and the assignment was based on the interpretation of the ${ }^{1} \mathrm{H}$ NMR and ${ }^{13} \mathrm{C}$ NMR spectra. The cyclization of 76 gave an inseparable mixture of 111 and 112 (Table 2, Entry 10). The yields of these two compounds were calculated from the ${ }^{1} \mathrm{H}$ NMR spectrum. It is interesting to note that the cyclization of compound $\mathbf{8 0}$ produced only the quinoxaline and none of the quinoxalinone was seen (Table 2, Entry 12). The cyclization of $\mathbf{8 2}$ gave slightly different products than the other reactions in that both $\mathbf{1 1 6}$ and 117 are fully aromatic (Table 2, Entry 13).

The differences in the NMR spectra of quinoxalines and 2-quinoxalinones are quite clear. For example, in the ${ }^{1} \mathrm{H}$ NMR spectra, the gem-dimethyl signal for the quinoxalinone is generally more downfield than that of the quinoxaline. For 3,4-dihydro-3,3,6-trimethyl-2-quinoxalinone (99), this signal appears at $1.40 \mathrm{ppm}$, while for 1,2-dihydro-2,2,7-trimethylquinoxaline (98), this signal is at $1.30 \mathrm{ppm}$. The $\mathrm{C}-\mathrm{H}$ on the nitrogen-containing ring of $\mathbf{9 8}$ shows an NMR signal at 7.23 ppm, while 99 shows no such signal. In the ${ }^{13} \mathrm{C} N M R$, the aliphatic quaternary carbon of compound 99 appears at 55.4 ppm, while the analogous carbon in 98 appears at 50.3 ppm. 
Table 2.' Synthesis of Quinoxalines and 2-Quinoxalinones

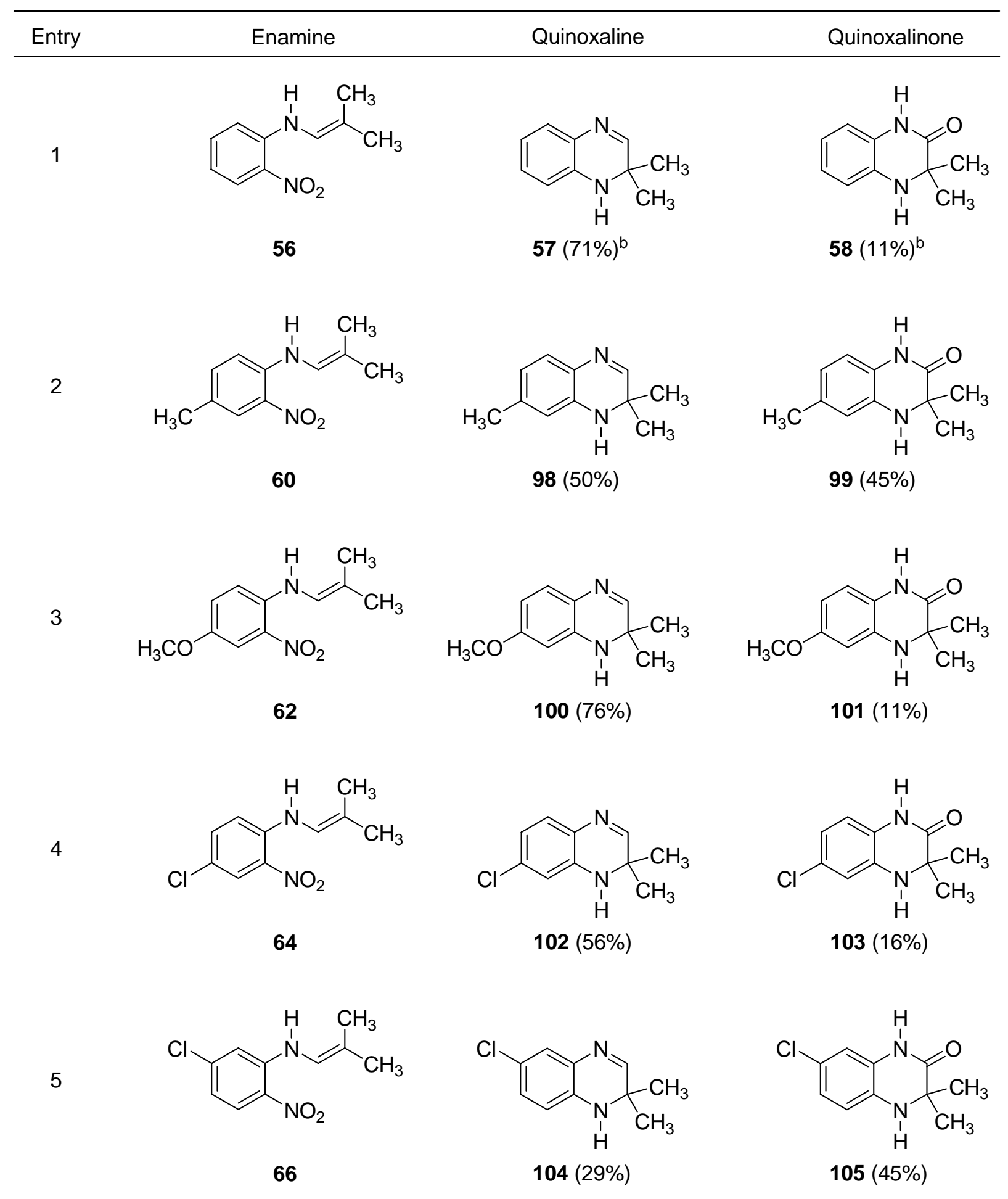


Table 2 (continued)

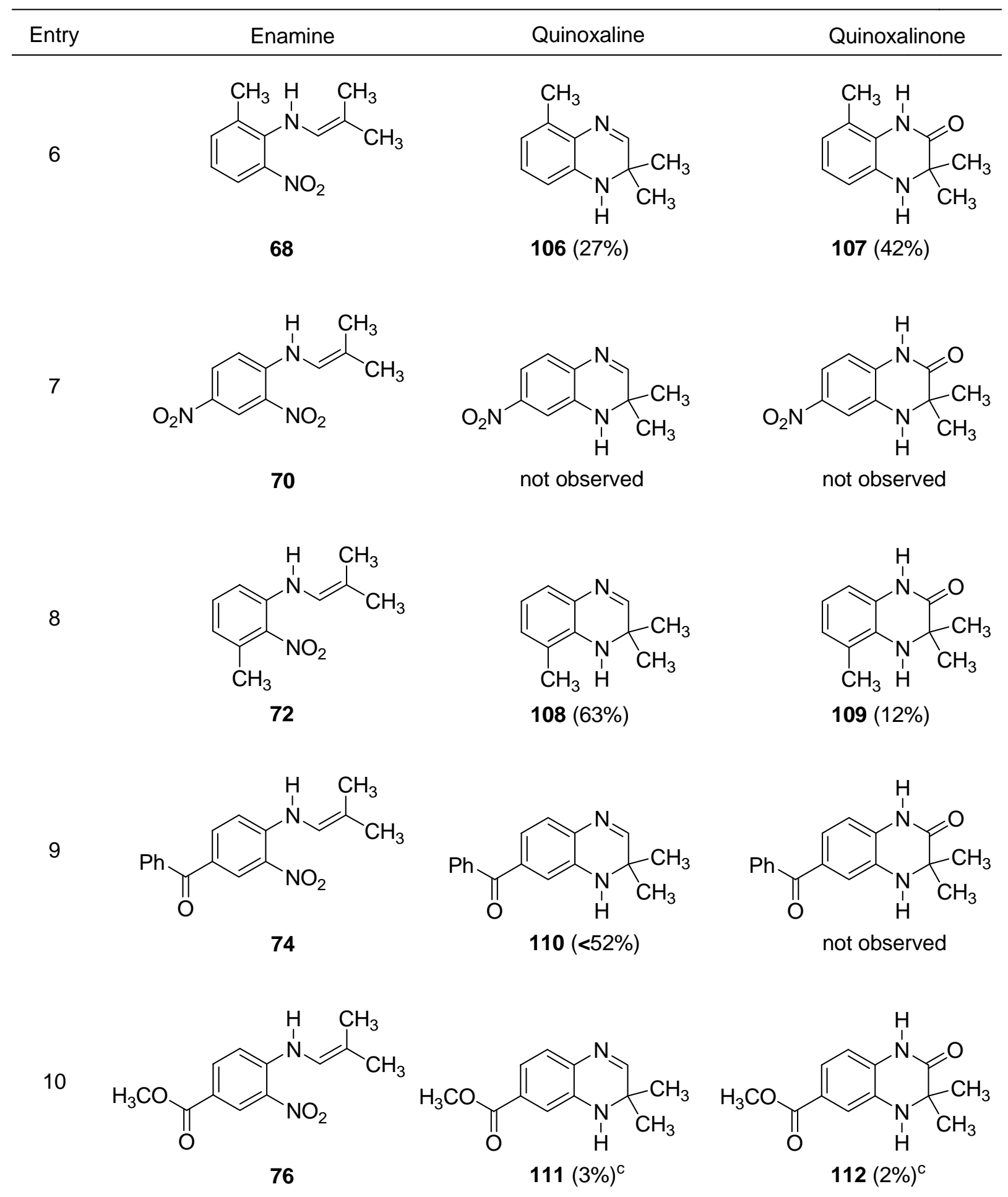


Table 2 (continued)

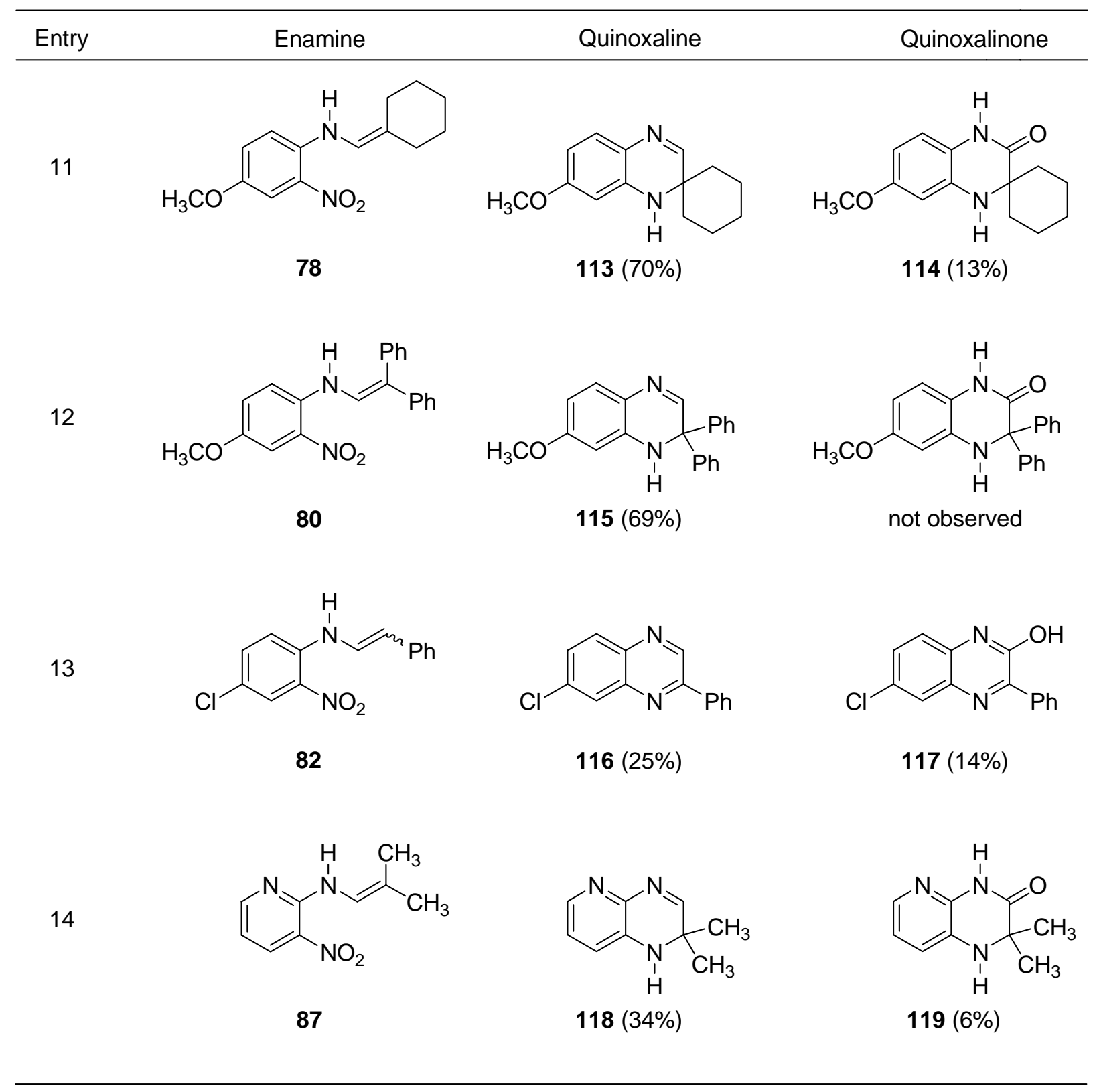

a) General conditions: $\mathrm{Pd}(\mathrm{dba})_{2}$ (6 mol\%), dppp (6 mol\%), phen (12 mol\%), CO (6 atm), DMF, $70^{\circ} \mathrm{C}$. For more exact details, see: Experimental Section. b) Conditions: $\mathrm{Pd}(\mathrm{dba})_{2}(6 \mathrm{~mol} \%)$, dppp (6 mol\%), $\mathrm{CO}$ (4 atm), $\mathrm{CH}_{3} \mathrm{CN}, 70^{\circ} \mathrm{C}$. c) Products were isolated as an inseparable mixture. Yields were estimated from the ${ }^{1} \mathrm{H}$ NMR spectrum. 
Next, we examined the cyclization of enamines derived from the condensation of 2nitroaminobenzenes and ketones. Compound $\mathbf{9 0}$ formed a mixture of three products when subjected to the reaction conditions (Scheme 25). Naturally occurring 1-hydroxyphenazine (120) is formed from the reaction in low yield. Compounds $\mathbf{1 2 1}$ and $\mathbf{1 2 2}$ were also formed in low yields. Compound 122 was aromatized using Pd/C (12.5 mol\% Pd), 1,2,4-trimethylbenzene (10 eq) in diphenyl ether at $230{ }^{\circ} \mathrm{C}$ for $20 \mathrm{~h}$ to give $\mathbf{1 2 0}$ in $20 \%$ yield. This leads us to believe that the product of the cyclization reaction is $\mathbf{1 2 2}$. In the reaction mixture, compound $\mathbf{1 2 2}$ is dehydrogenated by catalytic $\operatorname{Pd}(0)$ to give $\mathbf{1 2 0}$. Compound $\mathbf{9 0}$ may also undergo reduction of the nitro group to an amine and subsequent reaction of the amine with the carbonyl. Ultimately, this compound will tautomerize to form $\mathbf{1 2 1}$.

\section{Scheme 25. Cyclization of 90 and Aromatization of 122}<smiles>O=C1CCCC=C1Nc1ccccc1[N+](=O)[O-]</smiles>

90

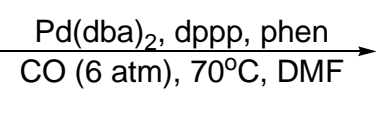

$\frac{\mathrm{Pd}(\mathrm{dba})_{2}, \mathrm{dppp}, \text { phen }}{\mathrm{CO}(6 \mathrm{~atm}), 70^{\circ} \mathrm{C}, \mathrm{DMF}}$

122

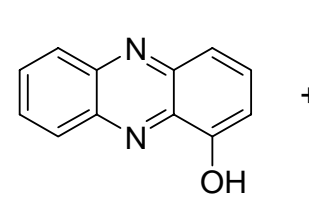

120 (6\%)<smiles>c1ccc2nc3c(nc2c1)CCCC3</smiles>

$121(8 \%)$<smiles>O=C1CCCc2nc3ccccc3nc21</smiles>

$122(15 \%)$

The reaction of $\mathbf{9 2}$ under slightly modified cyclization conditions gave $\mathbf{1 2 0}$ in relatively low yield (Scheme 26). The only modification to the conditions in this case was the increased temperature $\left(120^{\circ} \mathrm{C}\right)$. Although it could be envisioned that 122 could be formed in this reaction, it was not observed. 


\section{Scheme 26. Cyclization of 92}<smiles>O=C1C=C(Nc2ccccc2[N+](=O)[O-])CCC1</smiles>

92

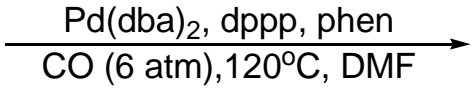

$120(26 \%)$

Acetylquinoxalines have also been prepared in low yields using our cyclization conditions. The reactions generally lead to the formation of the products in low yield. However, it is our hope that with small modifications to the procedure, our method will be a viable synthetic route to acetylquinoxalines. The reaction of $\mathbf{9 5}$ under the cyclization conditions gave $\mathbf{1 2 2}$ in $6 \%$ yield. Something interesting was discovered when the aryl ring was functionalized. When 96 was subjected to the same conditions, a mixture of regioisomers 124 and $\mathbf{1 2 5}$ were obtained in 13\% yield. Similarly, when 97 was cyclized, a mixture of the same isomers was obtained in $4 \%$ yield. When the results of the reactions are compared, the ratios of products are not the same indicating that the mixture formed in each case is not the thermodynamic mixture, but the kinetic mixture. The results of these reactions are shown in Scheme 27. 


\section{Scheme 27. Synthesis of Acetylquinoxalines}<smiles>CC(=O)/C=C\Nc1ccccc1[N+](=O)[O-]</smiles>

95

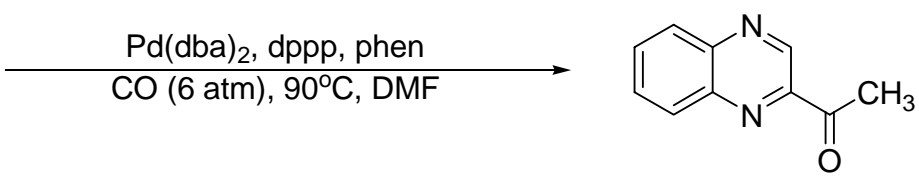

$123(6 \%)$<smiles>CC(=O)/C=C\Nc1ccc(C)cc1[N+](=O)[O-]</smiles>

96<smiles>CC(=O)/C=C\Nc1cc(C)ccc1[N+](=O)[O-]</smiles>

97

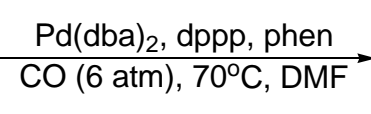
$\frac{\mathrm{Pd}(\mathrm{dba})_{2}, \mathrm{dppp}, \text { phen }}{\mathrm{CO}(6 \mathrm{~atm}), 70^{\circ} \mathrm{C}, \mathrm{DMF}}$

124<smiles>CC(=O)c1cnc2cc(C)ccc2n1</smiles>

124<smiles>CC(=O)c1cnc2ccc(C)cc2n1</smiles>

125 isolated as a mixture (1:1.3) in $13 \%$ yield isolated as a mixture (3.7:1) in $4 \%$ yield

We propose that the cyclization reactions proceed via the formation of a palladium-bound nitrene intermediate. The formation of this intermediate will be discussed in Part III. We also propose that the regioisomeric products formed in the above examples arise from the migration of the four carbon unit from one nitrogen to the other, resulting in the formation of isomeric nitrenes 126 and 130 (Scheme 28). These nitrenes should react in the same manner as discussed later in Part III to form the appropriate quinoxalines $\mathbf{1 2 5}$ and 124. It is assumed in each case that the major product arises from the initially formed nitrene and not the nitrene formed from the migration. 


\section{Scheme 28. Formation of Isomeric Nitrenes}<smiles>CC(=O)/C=C\Nc1ccc(C)cc1[N+](=O)[O-]</smiles>

96
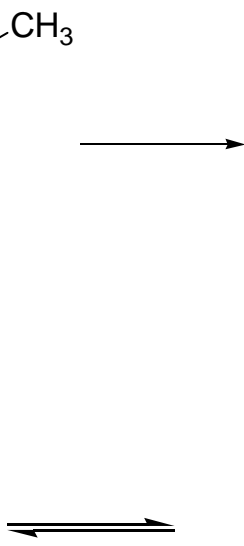

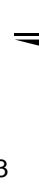<smiles>CC(=O)/C=C\Nc1ccc(C)cc1[N+]#[N+]</smiles>

126

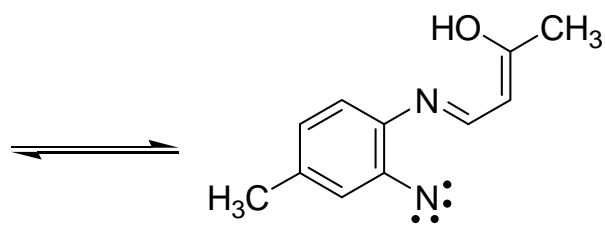

127
129<smiles></smiles><smiles>CC(O)=CC1N=c2ccc(C)cc2=N1</smiles>

128<smiles>CC(=O)/C=C\Nc1cc(C)ccc1C#N</smiles>

130<smiles>CC(=O)/C=C\Nc1cc(C)ccc1[N+](=O)[O-]</smiles>

97

As previously discussed, our attempts to form enamines by the condensation of 2nitroaminobenzenes and straight-chain aliphatic aldehydes failed. This result led us to try a different route. It is known that azides react with triphenylphosphine via the Staudinger reaction to form iminophosphoranes. ${ }^{28}$ These iminophosphoranes can then undergo aza-Wittig reactions with aldehydes and ketones to form imines. We decided to react 2-nitrophenylazides with triphenylphosphine, and then an aldehyde, in the hopes of isolating the corresponding imine or enamine. The reaction of 2-azidonitrobenzene (131), triphenylphoshine and heptanal (83) in the manner described above gave a red mixture which is a typical characteristic of the formation of 
an enamine. An attempt to purify the enamine by column chromatography resulted in complete decomposition of the product. It was then decided to form the expected enamine and subject the crude product to the cyclization conditions without further purification. Scheme 29 describes this two-step sequence that produced 2-pentylquinoxaline (132), 2-pentylquinoxaline-1-oxide (133) and 2-hexylbenzimidazole (134) in 25\%,8\% and 14\%, respectively. These results indicate that the aza-Wittig reaction first forms an imine, which would be expected to undergo nitrene insertion to produce benzimidazole 134. The imine might also isomerize to the enamine, which upon reaction with the nitrene would give quinoxaline 132. The mass spectrum of the compound designated to be $\mathbf{1 3 3}$ shows a peak at $\mathrm{m} / \mathrm{z}=199$. This peak would correspond to [M-17] $]^{+}$, or the loss of $\mathrm{OH}$, since the molecular weight of the $\mathrm{N}$-oxide is 216 . According to Bartoszek et al, ${ }^{29}$ quinoxaline- $N$-oxides substituted at the ortho position to the NO group give characteristic [M$\mathrm{OH}]^{+}$fragments. This, along with the rest of the fragmentation pattern and spectral data, led us to the conclusion that we did, in fact, isolate compound $\mathbf{1 3 3 .}$

\section{Scheme 29. Synthesis of 132, 133 and 134}

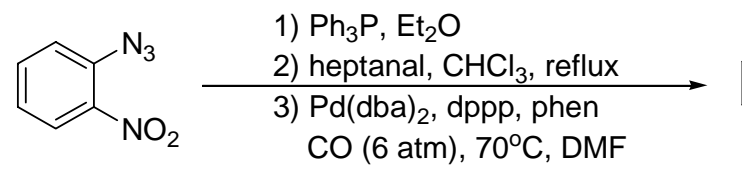

131<smiles>CCCCCCc1cnc2ccccc2n1</smiles>

$132(25 \%)$<smiles></smiles>

$133(8 \%)$<smiles>c1ccc(-c2nc3ccccc3[nH]2)cc1</smiles>

$134(14 \%)$

The reaction to form enamine $\mathbf{6 8}$ proceeded, although in very low yield (Table 1, Entry 6). It was our idea that a reaction of 2-azido-3-nitrotoluene (135) and 2-methylpropanal (55) in the manner described above might give a higher two-step yield of the cyclization products. In 
fact, the reaction gave 67, 106 and 136 in $8 \%, 11 \%$ and 62\%, respectively, and is described in Scheme 30.

Scheme 30. Synthesis of 67, 106 and 136<smiles>Cc1cccc([N+](=O)[O-])c1N</smiles>

135
1) $\mathrm{Ph}_{3} \mathrm{P}, \mathrm{Et}_{2} \mathrm{O}$

2) 2-methylpropanal, $\mathrm{CHCl}_{3}$, reflux

3) $\mathrm{Pd}(\mathrm{dba})_{2}$, dppp, phen CO (6 atm), $70^{\circ} \mathrm{C}, \mathrm{DMF}$<smiles>Cc1cccc([N+](=O)[O-])c1N</smiles>

$67(8 \%)$<smiles>Cc1cccc2c1N=CC(C)(C)N2</smiles>

$106(11 \%)$<smiles>Cc1cccc2[nH]c(C(C)C)nc12</smiles>

$136(62 \%)$

For the above study, it was necessary to synthesize two aryl azides for the Staudinger/aza-Wittig sequences. Compounds 131 and 135 were prepared in good yields via diazotization of the corresponding aminobenzene followed by treatment with sodium azide. The results of these reactions are shown in Scheme 31.

Scheme 31. Preparation of Azides 131 and 135<smiles>[R]c1cccc([N+](=O)[O-])c1N</smiles>

$52 \mathrm{R}=\mathrm{H}$

$67 \mathrm{R}=\mathrm{CH}_{3}$

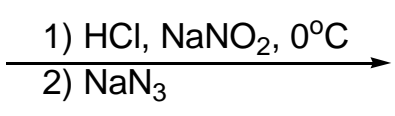

$131(80 \%), \mathrm{R}=\mathrm{H}$

$135(75 \%), \mathrm{R}=\mathrm{CH}_{3}$

In most of the cyclization reactions two products - a quinoxaline and a 2-quinoxalinone are formed in appreciable yields. We wanted to test various changes in the reaction conditions to 
see if one product could be formed exclusively. First, we subjected enamine $\mathbf{6 2}$ to the cyclization conditions and varied only the $\mathrm{CO}$ pressure. The reaction conditions for this set of experiments was $\mathrm{Pd}(\mathrm{dba})_{2}(6 \mathrm{~mol} \%)$, dppp (6 mol\%), phen (12 mol\%), CO (various pressures), DMF, $70{ }^{\circ} \mathrm{C}, 18 \mathrm{~h}$ (Scheme 32). The results of this study are summarized in Table 3. The results show that carbon monoxide is crucial for the reaction to take place. In the absence of carbon monoxide, the reaction did not proceed (Table 3, Entry 1). It is also interesting to note that the reaction proceeded well under ambient carbon monoxide pressure, indicating that for some substrates, higher pressures may not be necessary. It also seems that overall yields increase as the pressure is increased.

\section{Scheme 32. Cyclization Reactions under Various CO Pressures}

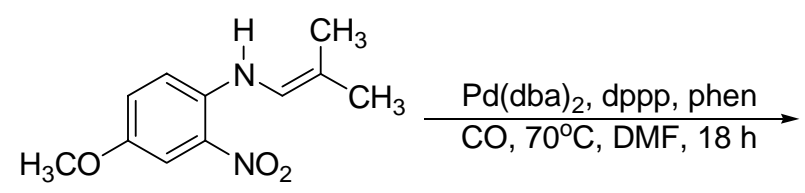

62

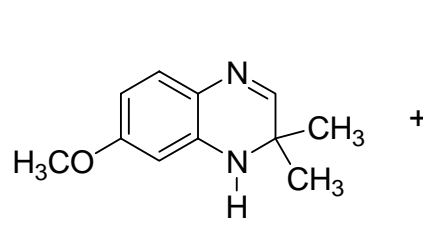

100<smiles>COc1ccc2c(c1)NC(C)(C)C(=O)N2</smiles>

101 
Table 3. ' Results of Cyclization Reactions under Various CO Pressures

\begin{tabular}{cccc}
\hline Entry & Co pressure (atm) & 100 & 101 \\
\hline 1 & $0^{\mathrm{b}}$ & $0 \%$ & $0 \%$ \\
2 & ambient $^{\mathrm{c}}$ & $70 \%$ & $10 \%$ \\
3 & 2 & $60 \%$ & $9 \%$ \\
4 & 4 & $86 \%$ & $6 \%$ \\
5 & 6 & $76 \%$ & $11 \%$ \\
6 & 8 & $88 \%$ & $3 \%$ \\
7 & 16 & $99 \%$ & $1 \%$ \\
\hline
\end{tabular}
a) Isolated yields of $\mathbf{1 0 0}$ and $\mathbf{1 0 1}$ are reported.
b) No carbon monoxide was added to the reaction vessel.
c) The reaction vessel was flushed with carbon monoxide.

Next, we varied the reaction times for the cyclizations. The reaction conditions for this set of experiments was $\operatorname{Pd}(\mathrm{dba})_{2}(6 \mathrm{~mol} \%)$, dppp (6 mol\%), phen (12 mol\%), CO (6 atm), DMF, $70{ }^{\circ} \mathrm{C}$ (Scheme 33). The results of this study are summarized in Table 4. It was determined that longer reaction times served no benefit and any differences in the yields of products were probably within standard error.

\section{Scheme 33. Cyclization Reactions with Various Reaction Times}

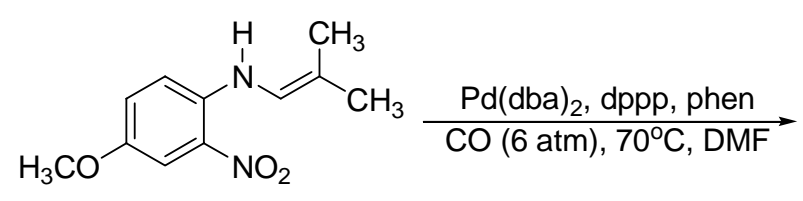

62<smiles>COc1ccc2c(c1)NC(C)(C)C=N2</smiles>

100<smiles>COc1ccc2c(c1)NC(C)(C)C(=O)N2</smiles>

101 


\section{Table 4. Results of Cyclization Reactions with Various Reaction Times}

\begin{tabular}{cccc}
\hline Entry & reaction time $(\mathrm{h})$ & 100 & 101 \\
\hline 1 & 1 & $73 \%$ & $10 \%$ \\
2 & 4 & $77 \%$ & $2 \%$ \\
3 & 18 & $76 \%$ & $11 \%$ \\
4 & 36 & $88 \%$ & $1 \%$ \\
\hline
\end{tabular}

We also tested the effect of $\mathrm{H}_{2} \mathrm{O}$ in the reaction mixture. The reaction conditions for this set of experiments was $\mathrm{Pd}(\mathrm{dba})_{2}(6 \mathrm{~mol} \%)$, dppp (6 mol\%), phen $(12 \mathrm{~mol} \%), \mathrm{CO}(6 \mathrm{~atm}), 70{ }^{\circ} \mathrm{C}$, $18 \mathrm{~h}$ (Scheme 34). The results of this study are summarized in Table 5. When the reaction was performed using $\mathrm{H}_{2} \mathrm{O}$ as the solvent no reaction took place (Table 5, Entry 1). This result may be because of a limited solubility of the enamine and other reagents in $\mathrm{H}_{2} \mathrm{O}$. When the reaction was performed in a 1:1 mixture of $\mathrm{DMF} / \mathrm{H}_{2} \mathrm{O}$ an increased yield of quinoxaline $\mathbf{1 0 0}$ was seen, while no 101 was isolated (Table 5, Entry 2). The most interesting result was obtained when the reaction was performed in DMF, but 6 equivalents of $\mathrm{H}_{2} \mathrm{O}$ were added to the reaction mixture (Table 5, Entry 3). In this experiment $\mathbf{1 0 0}$ was isolated in $80 \%$ yield, while $\mathbf{1 0 1}$ was not seen. 
<smiles>COc1ccc2c(c1)NC(C)(C)C(=O)N2</smiles>

\section{Table 5. Results of Cyclization Reactions with Various Solvent Mixtures}

\begin{tabular}{cccc}
\hline Entry & Solvent $^{\mathrm{a}}$ & 100 & 101 \\
\hline 1 & & & \\
2 & $\mathrm{H}_{2} \mathrm{O}$ & $0 \%$ & $0 \%$ \\
3 & $\mathrm{DMF} / \mathrm{H}_{2} \mathrm{O}(1: 1)$ & $37 \%$ & $0 \%$ \\
\hline
\end{tabular}

a) General conditions: $\mathrm{Pd}(\mathrm{dba})_{2}$ (6 mol\%), dppp (6 mol\%), phen (12 mol\%), $\mathrm{CO}(6 \mathrm{~atm}), 70^{\circ} \mathrm{C}, 18 \mathrm{~h}$. The solvent used is listed. b) 6 equivalents of $\mathrm{H}_{2} \mathrm{O}$ was added to the reaction mixture.

Encouraged by the previous results, we decided to attempt the cyclization of more substrates under the conditions described in Table 5, Entry 3. The results of these reactions are shown in Scheme 35. When enamine $\mathbf{6 4}$ was subjected to these new conditions, quinoxaline 102 was obtained in 96\% yield, while quinoxalinone 103 was obtained in $4 \%$ yield. The quinoxaline/quinoxalinone yield was $56 \% / 16 \%$ when the reaction was performed without the addition of $\mathrm{H}_{2} \mathrm{O}$ (Table 2, Entry 4). Similarly, when $\mathbf{6 6}$ was reacted under the conditions that included the addition of 6 eq of $\mathrm{H}_{2} \mathrm{O}, \mathbf{1 0 4}$ and $\mathbf{1 0 5}$ were obtained in $81 \%$ and $18 \%$, respectively. This result is especially interesting given that the same reaction performed under the original 
conditions gave quinoxalinone $\mathbf{1 0 5}$ as the major product (Table 2, Entry 5). Further investigation is planned to determine the scope of these reaction conditions.

\section{Scheme 35. Cyclization Reactions with the Addition of Excess Water}<smiles>[R]c1cc(NC=C(C)C)c([N+](=O)[O-])cc1[R]</smiles>

64, $\mathrm{R}^{1}=\mathrm{H}, \mathrm{R}^{2}=\mathrm{Cl}$ 66, $\mathrm{R}^{1}=\mathrm{Cl}, \mathrm{R}^{2}=\mathrm{H}$
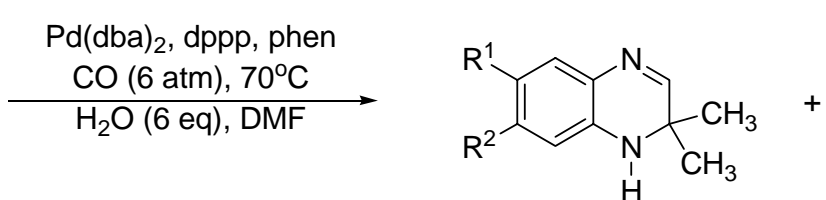

$102(96 \%), R^{1}=H, R^{2}=C l$ $104(81 \%), \mathrm{R}^{1}=\mathrm{Cl}, \mathrm{R}^{2}=\mathrm{H}$

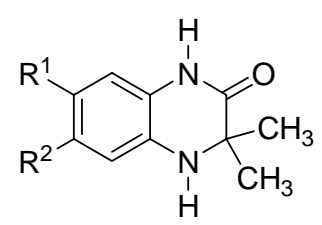

$103(4 \%), \mathrm{R}^{1}=\mathrm{H}, \mathrm{R}^{2}=\mathrm{Cl}$ $105(18 \%), \mathrm{R}^{1}=\mathrm{Cl}, \mathrm{R}^{2}=\mathrm{H}$

\section{Conclusions}

A mild and efficient route to quinoxalines and 2-quinoxalinones using a palladiumcatalyzed cyclization reaction was developed. A variety of functional groups and substitution patterns are tolerated by this reaction. However, generally lower yields are obtained for substrates containing an electron withdrawing group. Also, it appears as if the ratio of products obtained in the reaction can be manipulated by slightly changing the reaction conditions, namely the addition of $\mathrm{H}_{2} \mathrm{O}$ to the reaction mixture. 


\section{Part III}

\section{Investigation into the Mechanism of the Palladium-Catalyzed $N$ - Heteroannulation Reactions}

\section{Mechanistic Investigation}

The mechanism of the cyclizations of $N$-(2-nitroaryl)enamines to quinoxalines and 2quinoxalinones has been investigated. Transition metal-catalyzed deoxygenation of organic nitro compounds has been proposed to proceed via the formation of nitrene, or nitrenoid, intermediates. ${ }^{30}$ Carbon monoxide is crucial for the reaction to proceed, functioning as a reducing agent to give a metal-bound nitrene and carbon dioxide. Metal-bound nitrenes have been previously reported. For example, a ruthenium-bound derived from 2-nitrosobiphenyl has been isolated and characterized by X-ray crystallography. ${ }^{31}$ Decomposition of this complex gave the expected nitrene insertion product. We propose a mechanism for the formation of a palladium-bound nitrene intermediate under our reaction conditions. This mechanism is detailed in Scheme 36.

Scheme 36. Proposed Mechanism for the Formation of a Palladium-bound Nitrene

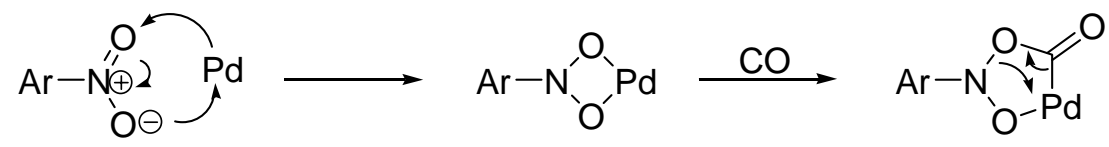

137

138

139

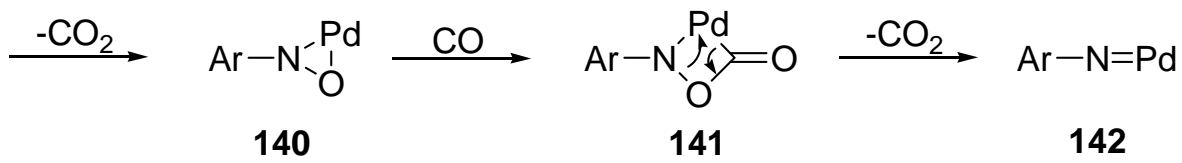


The mechanism for the formation of the quinoxaline/quinoxalinone products is unclear; however, we propose possible mechanisms for their respective formations. The proposed mechanism for the formation of quinoxalines is detailed in Scheme 37. In this mechanism, the partially negative carbon of the enamine reacts with the partially positive nitrogen of the palladium-bound nitrene in a formal [2+2] intramolecular cycloaddition to form bicyclic species 144. Sequential $\beta$-hydride elimination to give $\mathbf{1 4 5}$ followed by reductive elimination would form the quinoxaline (57) and regenerate the palladium(0) catalyst.

\section{Scheme 37. Proposed Mechanism for the Formation of Quinoxalines}

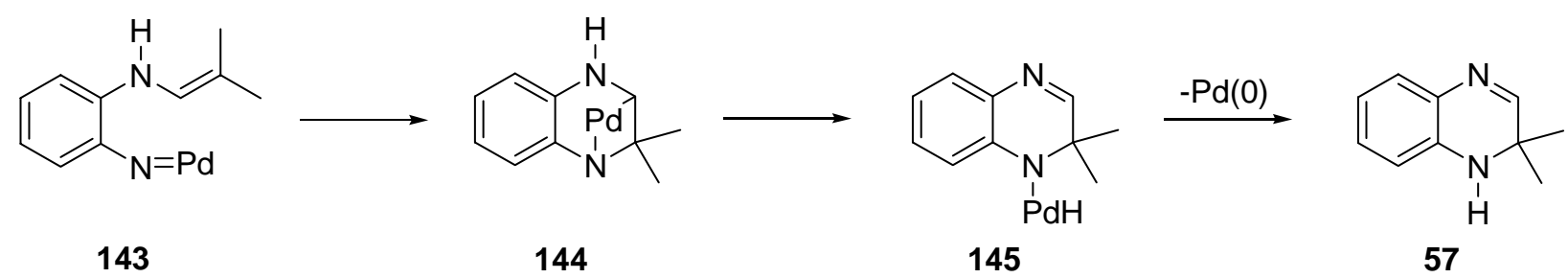

Our proposed mechanism for the formation of 2-quinoxalinones is detailed in Scheme 38. Before complete deoxygenation to give the palladium-bound nitrene, insertion of the alkene into the intermediately formed metallacycle 146 (a palladium-bound nitrosoarene) occurs. Two different insertion products can be envisioned; one resulting from the insertion of the alkene into the Pd-O bond (147) and the other from the insertion into the $\mathrm{N}-\mathrm{O}$ bond (148) of the metallacycle. The latter seems to be the species more likely formed since a simple $\beta$-hydride elimination-reductive elimination sequence would give a 2-quinoxalinone. Intramolecular 
insertions of alkenes into metal-bound nitrosoarenes, the first step in this sequence, have been

proposed. $^{32}$

Scheme 38. Proposed Mechanism for the Formation of 2-Quinoxalinones<smiles>CC(C)=CNc1ccccc1-n1[nH]o1</smiles>

146<smiles>CC1(C)[Pb]N2OC1Nc1ccccc12</smiles>

147

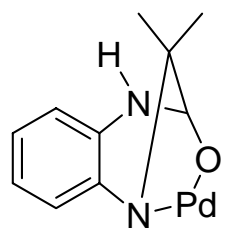

148

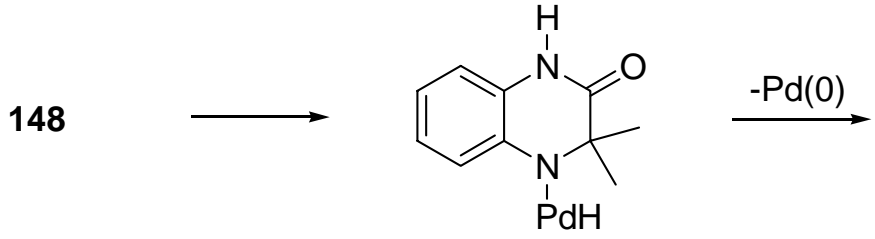

149<smiles>CC1(C)Nc2ccccc2NC1=O</smiles>

58

By subjecting compound $\mathbf{1 0 2}$ to the cyclization conditions we have shown that oxidation of the quinoxaline does not lead to the 2-quinoxalinone; compound 102 was recovered unchanged from the reaction mixture. By an analogous reaction of 105, we have also shown that the 2-quinoxalinone is not reduced under the same conditions. These studies are illustrated in Scheme 39. 


\section{Scheme 39. Reaction of 102 and 105 under Cyclization Conditions}
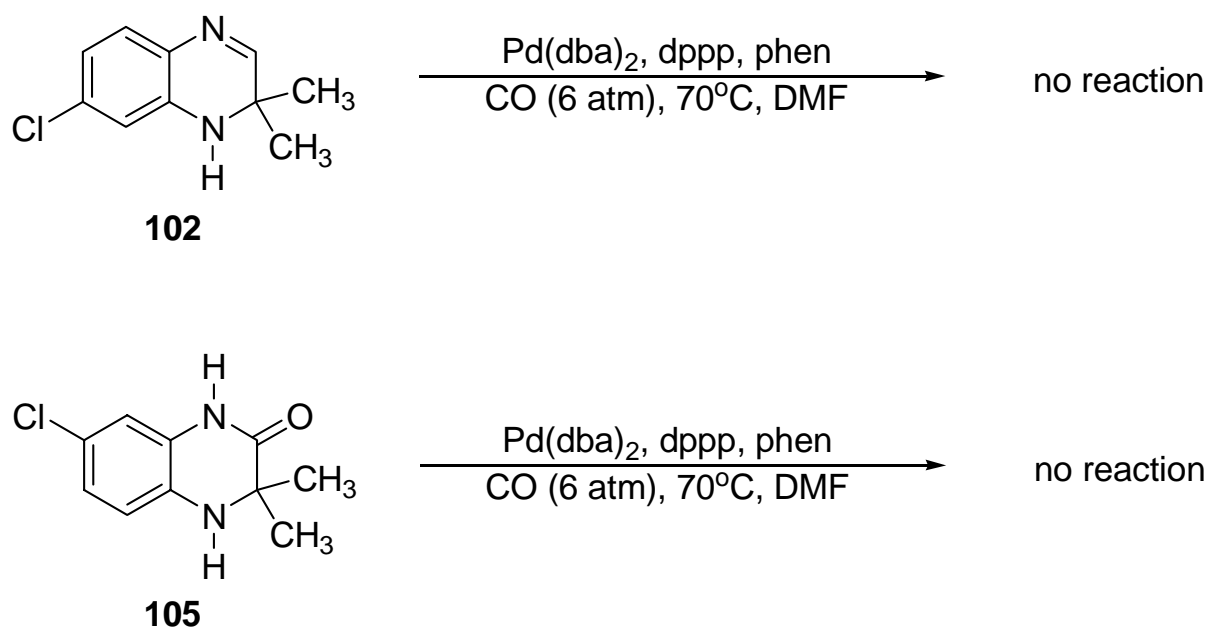

It is established that a nitrene species is formed upon the thermolysis of azides. ${ }^{30}$ Therefore, in order to further investigate the mechanism of the cyclization reactions, we attempted to prepare $N$-(2-azidoaryl)enamines. The attempted condensation of 2azidoaminobenzenes with aldehydes in the presence of molecular sieves under previously described conditions was met with no success. However, the condensation of 2azidoaminobenzene and various aryl aldehydes in the presence of catalytic acetic acid in refluxing ethanol to form the corresponding imine is described by Alajarín et al. ${ }^{33}$ Although the product isolated by Alajarín was an imine, we thought that by using aliphatic aldehydes and considering our previous experience with the condensations of aminobenzenes and, for example, 2-methylpropanal, that it might be possible to form the enamine under these conditions.

The condensation of 2-azido-4-chloroaminobenzene (150) (the synthesis of 150 will be discussed in the next section) and 2-methylpropanal (55) was attempted. The only isolated product was 5-chloro-2-isopropylbenzimidazole (151) in 61\% yield. This result indicates that if 
a nitrene is formed upon heating, it reacts with the initially formed imine from the condensation reaction to give the benzimidazole. The benzimidazole is the expected nitrene insertion product from such a reaction according to Krbechek et al. ${ }^{34}$ The result of this reaction is described in Scheme 40. The formation of 2-alkylbenzimidazoles under these conditions was pursued further and the results are described in the next section.

\section{Scheme 40. Synthesis of Benzimidazole 151}<smiles>Nc1ccc(Cl)cc1N</smiles>

150<smiles>CC(C)C=O</smiles>

55

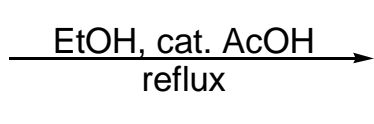

$151(61 \%)$

We still desired to isolate a $N$-(2-azidoaryl)enamine, but it was clear that the condensation of an aminobenzene and an aldehyde was not the route to take. We attempted the addition-elimination reaction of 2-azido-4-methylaminobenzene (152) (the synthesis of 152 will be discussed in the next section) and (E)-4-methoxy-3-buten-2-one (94) to form (Z)-4-(2-azido4-methylphenylamino)-3-buten-2-one (153). This reaction proceeded smoothly to give the desired product in $78 \%$ yield (Scheme 41 ). 
<smiles>Cc1ccc(N)c(N)c1</smiles>

152<smiles>CO/C=C/C(C)=O</smiles>

94<smiles>CC(=O)/C=C\Nc1ccc(C)cc1N</smiles>

$153(78 \%)$

With this result in hand, compound 153 was refluxed in ethanol in the presence of catalytic $p$-toluenesulfonic acid. This reaction produced an inseparable mixture $(6: 1)$ of quinoxalines 125 and 124 (Scheme 42) similar to the cyclizations of $N$-(2-nitroaryl)enamines 96 and 97 (Scheme 27, Part II). This indicates that a nitrene intermediate is a possibility in the palladium-catalyzed $N$-heteroannulations of $N$-(2-nitroaryl)enamines to form quinoxalines and 2quinoxalinones.

\section{Scheme 42. Synthesis of 124 and 125}<smiles>CC(=O)/C=C\Nc1ccc(C)cc1N</smiles>

153

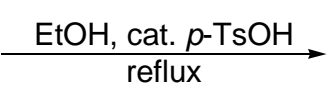

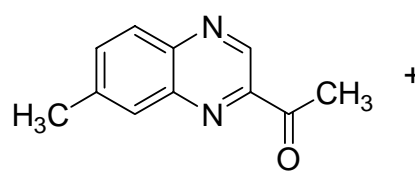

125<smiles>CC(=O)c1cnc2cc(C)ccc2n1</smiles>

124

isolated as a mixture $(6: 1)$ in $6 \%$ yield

It has been reported that organic azides react with a variety of transition metals, such as $\mathrm{Mo},{ }^{35} \mathrm{~W}^{36}$ and $\mathrm{Fe},{ }^{37}$ to form metal-bound nitrenes. We decided to react compound $\mathbf{1 5 3}$ with a $\operatorname{Pd}(0)$ catalyst in the hopes of forming the palladium-bound nitrene species. The reaction of 
compound 153 with $\mathrm{Pd}(\mathrm{dba})_{2}$ and dppp in DMF at ambient temperature produced a product that is tentatively designated as $\mathbf{1 5 4}$ in 18\% yield (Scheme 43). This result also supports the hypothesis that a nitrene intermediate is involved in the formation of the quinoxaline ring system by the palladium-catalyzed $N$-heteroannulations of $N$-(2-nitroaryl)enamines.

\section{Scheme 43. Synthesis of 154}

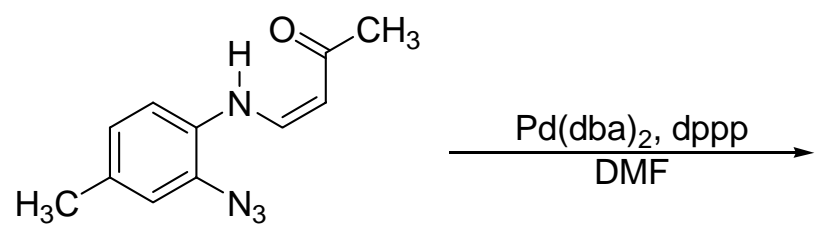

153<smiles>CC(=O)C1=CNc2ccc(C)cc2N1</smiles>

154 (18\%)

In our proposed mechanism for the formation of a nitrene intermediate (Scheme 36), it can be envisioned that species $\mathbf{1 4 0}$, which is formally palladium coordinated to a nitroso group, could also exist as the "free" nitroso group (Scheme 44). It is also curious if this "free" nitroso group is part of the catalytic cycle. To test this, 2-nitrosoaminobenzene (157) was prepared according to Haddadin et $a l^{38}$ and then reacted with 2-methylpropanal (55) in DMF at $80^{\circ} \mathrm{C}$. This reaction produced only 2-isopropylbenzimidazole (158) in 16\% yield (Scheme 45). This result indicates that the "free" nitroso group is not part of the catalytic cycle in the reactions forming quinoxalines and 2-quinoxalinones. 
Scheme 44. Illustration of 140 as an Aryl Nitroso Group

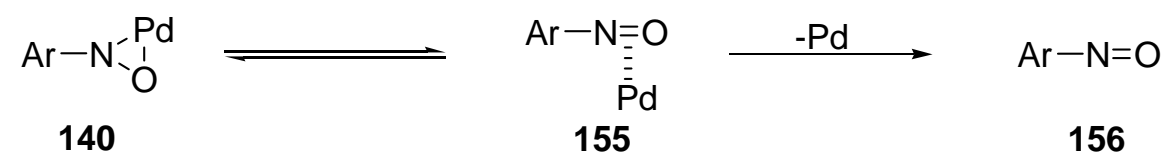

Scheme 45. Reaction of 2-Nitrosoaminobenzene with 2-Methylpropanal<smiles>Nc1ccccc1N=O</smiles>

157<smiles>CC(C)C=O</smiles>

55

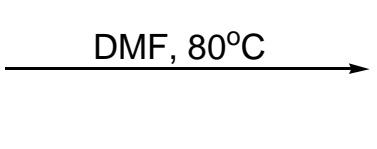

\section{Conclusions}

We have proposed a reasonable mechanism for the palladium-catalyzed $N$ heteroannulation of $\mathrm{N}$-(2-nitroaryl)enamines to quinoxalines and 2-quinoxalinones that involves the formation of a palladium-bound nitrene as a key step. We have designed several experiments to test the viability of our proposed mechanism and the results of all of them have been in support. 


\section{Part IV}

\section{Novel Synthesis of 2-Alkylbenzimidazoles}

\section{Introduction}

The benzimidazole nucleus is present in many physiologically active compounds.

Examples of benzimidazoles possessing biological activity are omeprazole, an antiulcerative marketed by AstraZeneca under the names Prilosec (racemic) and Nexium (magnesium salt of the $S$-isomer), and thiabendazole, a veterinary anthelmintic and fungicide for spoilage control of citrus fruit and for the prevention of Dutch elm disease (Figure 3). Other benzimidazoles exhibit antifertility, ${ }^{39}$ antitumor, ${ }^{40}$ anthelmintic, ${ }^{41}$ fungicidal,${ }^{42}$ antiviral ${ }^{43}$ and antiarrhythmic ${ }^{44}$ activity. This variety of physiological activity makes the benzimidazole ring structure a worthwhile synthetic target for researchers.

\section{Figure 3. Omeprazole and Thiabendazole}<smiles>COc1ccc2[nH]c(S(=O)Cc3ncc(C)c(OC)c3C)nc2c1</smiles>

omeprazole

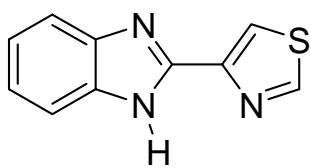

thiabendazole

A wide variety of synthetic methods for the preparation of benzimidazoles have been reported. Bárzana et al reports the synthesis of benzimidazoles (161) and 1hydroxybenzimidazoles (160) from 4-alkyl-2-nitroacetanilides (159) by reductive cyclization with baker's yeast (Scheme 46). ${ }^{45}$ The ortho nitro group of $\mathbf{1 5 9}$ is reduced by the yeast to the 
corresponding hydroxylamine which then undergoes an intramolecular reaction with the amide carbonyl to give the 1-hydroxybenzimidazole (160). The hydroxylamine could also undergo a second reduction to the amine, which then undergoes an analogous cyclization to the benzimidazole (161). Interestingly, when the substituent on the aryl ring is a nitro group $(\mathrm{R}=$ $\mathrm{NO}_{2}$ ), only the nitro in the ortho position is reduced. High conversion rates are generally associated with this reaction. However, a potential drawback is that the reaction only works when the substituent is an electron withdrawing group.

\section{Scheme 46. The Work of Bárzana et al}

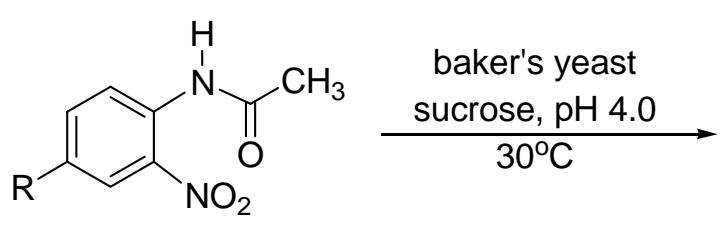

159<smiles>[R]c1ccc2nc(C)n(O)c2c1</smiles>

160<smiles>[R]c1ccc2nc(C)[nH]c2c1</smiles>

161

$\begin{array}{ccc}\underline{\mathrm{R}} & \underline{\mathbf{1 6 0}} & \underline{\mathbf{1 6}} \\ \mathrm{OCH}_{3} & 0 \% & 0 \% \\ \mathrm{NO}_{2} & 32 \% & 64 \%\end{array}$

It has been shown by Grenda et al that the reaction of $N$-arylamidine hydrochlorides (162) with sodium hypochlorite and base form benzimidazoles (163) in moderate to good yield (Scheme 47). ${ }^{46}$ This sequence can be used to form 2-alkyl and 2-arylbenzimidazoles with better yields generally accompanying the latter. These reactions require the formation of an amidine from the reaction of an aryl amine with a nitrile or an imidate prior to cyclization. A possible 
drawback of this procedure is that if the aryl ring were substituted the cyclization will most likely give regioisomeric products.

\section{Scheme 47. The Work of Grenda et al}

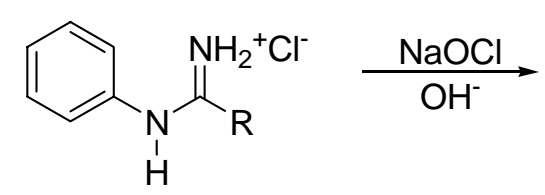

162

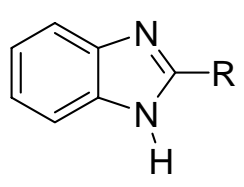

$163(70-96 \%)$

The synthesis of 2-alkylbenzimidazoles by $\mathrm{TiO}_{2}$-mediated photocatalysis is reported by Li et al. In this example, alcoholic solutions of 1,2-dinitrobenzenes (164) are irradiated in the presence of $\mathrm{TiO}_{2}$ to form 2-alkylbenzimidazoles (165) in good yield (Scheme 48). ${ }^{47}$ The reaction involves the oxidation of the alcohol solvent to the corresponding aldehyde and the reduction of the dinitrobenzene to a 2-nitroaminobenzene. This is followed by intermolecular condensation to form the corresponding imine. Further reduction of the nitro group on the imine to the hydroxylamine followed by intramolecular cyclization and dehydration gives 2alkylbenzimidazoles. Solvents, and therefore aldehydes, were limited to ethanol and 1-propanol to give methyl and ethyl substituted benzimidazoles, respectively. It seems that this procedure is limited to alcohols that serve as good solvents for the reaction. Also, substrates possessing an electron withdrawing group tended to give lower yields of benzimidazoles. 


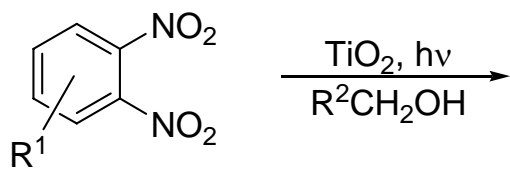

164

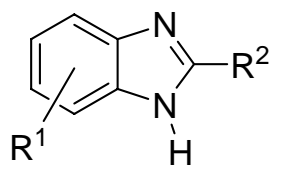

$165(70-97 \%)$

Another transition metal-catalyzed preparation of benzimidazoles is reported by Perry et al. ${ }^{48}$ In this sequence, described in Scheme 49, aryl halides (166) are reacted with 1,2diaminobenzenes (30) in the presence of carbon monoxide, a palladium catalyst and a base to form 2-arylbenzimidazoles (167) in good yields. This procedure tolerates a variety of functional groups on either of the aromatic rings. Some side products are seen in the reaction, such as bisamides, resulting from the reaction of both amino groups with two Ar-C(O)-Pd-X species. However, these products seem to be sufficiently diminished or eliminated by changing the base or solvent.

\section{Scheme 49. The Work of Perry et al}<smiles>[R]c1ccc(N)c(N)c1</smiles>

30<smiles>[R]c1ccc([X])cc1</smiles>

$$
166
$$<smiles>[R]c1ccc(-c2nc3cc([R])ccc3[nH]2)cc1</smiles>

$167(60-98 \%)$ 
Thomas et al reported the synthesis of benzimidazoles by the tin(II) chloride reduction of 2-nitroaminobenzenes followed by condensation with alkanoic anhydrides (Scheme 50). ${ }^{49}$ For example, fluoro substituted 2-nitroaminobenzene 168 is reduced with $\mathrm{SnCl}_{2}$ followed by the reaction with pentanoic anhydride to give the corresponding benzimidazole (169) in 48\% yield. The low yield of this reaction along with the need for 5 equivalents of $\mathrm{SnCl}_{2}$ does not serve to make this method of benzimidazole preparation the most efficient.

Scheme 50. The Work of Thomas et al

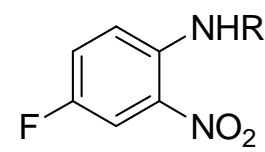

168

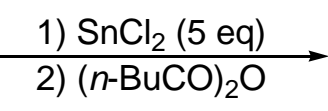

2) $(n-\mathrm{BuCO})_{2} \mathrm{O}$

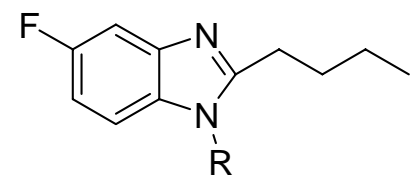

$169(48 \%)$

The reaction of 1,2-diaminobenzenes (30) with aliphatic selenonesters (170) to produce 2-alkylbenzimidazoles (171) is reported by Cohen et al. ${ }^{50}$ This method is described in Scheme 51. The reaction proceeds smoothly in the unsubstituted system as well as with an electron donating substituent $\left(\mathrm{R}=\mathrm{CH}_{3}\right)$ on the aryl ring to afford the corresponding 2-alkybenzimidazole in $92 \%$ and $86 \%$ yields, respectively. However, the yield of the reaction drops sharply with an electron withdrawing group $(\mathrm{R}=\mathrm{Cl})$ on the aryl ring. Another potential drawback of this method is the production of moderately toxic hydrogen selenide as a byproduct. 
<smiles>[R]c1ccc(N)c(N)c1</smiles>

30<smiles>[R]C(=[Se])OCC</smiles>

170

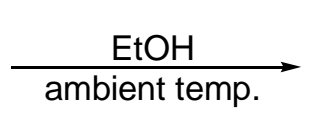

$\underline{\mathbf{R}}^{2}$

$$
n \text {-pentyl }
$$$$
n \text {-propyl }
$$

$n$-pentyl<smiles>[R]c1ccc2[nH]c([R])nc2c1</smiles>

171

$\begin{array}{ccc}\underline{\mathbf{R}}^{\mathbf{1}} & \underline{\mathbf{R}}^{\mathbf{2}} & \underline{\mathbf{1 7 1}} \\ \mathrm{H} & n \text {-pentyl } & 92 \% \\ \mathrm{CH}_{3} & n \text {-propyl } & 86 \% \\ \mathrm{Cl} & n \text {-pentyl } & 50 \%\end{array}$

A ruthenium-catalyzed route to benzimidazoles is reported by Cenini et al (Scheme 52). ${ }^{51}$ The reaction of 2-nitroaminobenzene (52) with aliphatic or aromatic aldehydes (172) in the presence of $\mathrm{Ru}_{3}(\mathrm{CO})_{12}(2.5 \mathrm{~mol} \%)$ and carbon monoxide (49 atm) gives 2-alkyl and 2arylbenzimidazoles (163) in moderate to good yield. The reaction is proposed to proceed through an imine intermediate followed by the formation of a ruthenium-bound nitrene. The nitrene then inserts into the $\mathrm{C}-\mathrm{H}$ bond of the imine to form the benzimidazole.

\section{Scheme 52. The Work of Cenini et al}

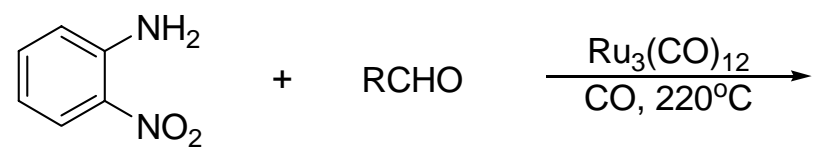

52
172

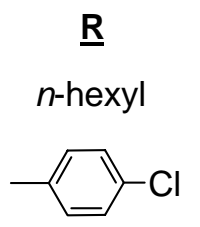<smiles>[R]c1nc2ccccc2[nH]1</smiles>

163 
Another route to benzimidazoles that probably proceeds through a nitrene intermediate is the reductive cyclization of $N$-benzilidene-2-nitroaminobenzenes (173) by triethyl phosphite (Scheme 53). The formation of a nitrene species by phosphorus-promoted deoxygenation of aromatic nitro compounds has been proposed. ${ }^{30}$ This reaction, reported by Cadogan et al, ${ }^{52}$ forms 2-phenylbenzimidazoles (174) in moderate to low yields.

\section{Scheme 53. The Work of Cadogan et al}<smiles>[R]c1ccc(/N=C/c2ccccc2)c([N+](=O)[O-])c1</smiles>

173

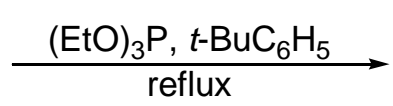

$\begin{array}{cc}\underline{\mathbf{R}} & \underline{\mathbf{1 7 4}} \\ \mathrm{H} & 47 \% \\ \mathrm{CH}_{3} & 33 \%\end{array}$

The thermolysis of aromatic azides is also known to form nitrenes. ${ }^{30}$ The work of Hall et $a l^{53}$ is described in Scheme 54. In this sequence, imines (177) are prepared in moderate to good yields by the reaction of 2-azidoaminobenzenes (175) with aromatic aldehydes (176). Thermolysis of these azido imines at $130{ }^{\circ} \mathrm{C}$ in $\mathrm{DMF}$ presumably forms the nitrene intermediate, which undergoes $\mathrm{C}-\mathrm{H}$ insertion to form the 2-arylbenzimidazoles (178). The two-step yields in these reactions are generally moderate to low. 


\section{Scheme 54. The Work of Hall et al}

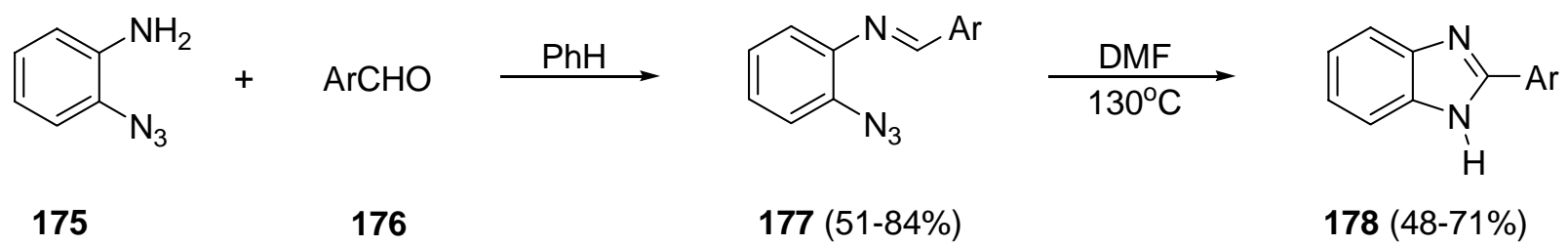

There are many different methods of forming the benzimidazole ring system. Many of these methods are not without limitations. Some require the multi-step formation of a cyclization precursor which lowers overall yields. Many methods are intolerant of certain functional groups. We have developed an extremely mild single-step route to 2 alkylbenzimidazoles via sequential condensation-nitrene insertion reactions. Our method tolerates a variety of substituents (electron-donating and withdrawing) as well as different substitution patterns. Also, our reactions typically give 2-alkylbenzimidazoles in moderate to good yields. The novel synthesis of a variety of 2-alkylbenzimidazoles is presented.

\section{Results and Discussion}

Encouraged by the results of the reaction described in Scheme 40 (Part III), we decided to pursue the preparation of 2-alkylbenzimidazoles by reacting 2-azidoaminobenzenes with aldehydes in refluxing ethanol. It was necessary to first prepare a number of substituted 2azidoaminobenzenes. Compounds 186 and $\mathbf{1 5 0}$ were prepared by the method of Hall et al (Scheme 55). ${ }^{54}$ First, the appropriate 2-nitroaminobenzenes (65 and 63) were melted with phthalic anhydride (179) to form the corresponding 2-phthalamidonitrobenzenes (180 and 181). Despite the relatively low yields of these reactions we decided to move forward in the sequence. 
Subsequent reduction of 180 and 181 by iron and acetic acid produced 182 and 183, respectively, in good yields. Next, the 2-phthalamidoaminobenzenes (182 and $\mathbf{1 8 3})$ were subjected to diazotization conditions followed by treatment with sodium azide. This sequence produced 2phthalamidophenylazides $\mathbf{1 8 4}$ and $\mathbf{1 8 5}$ in 75\% and 59\% yields, respectively. The final step of the series was the removal of the phthalamide protecting group. This was performed using hydrazine hydrate and gave compounds 186 and 150 in 54\% and 62\% yields, respectively.

\section{Scheme 55. Preparation of 186 and 150}<smiles>[R]c1cc(N)c([N+](=O)[O-])cc1[R]</smiles>

$65 \mathrm{R}^{1}=\mathrm{Cl}, \mathrm{R}^{2}=\mathrm{H}$ $63 \mathrm{R}^{1}=\mathrm{H}, \mathrm{R}^{2}=\mathrm{Cl}$<smiles>O=C1OC(=O)c2ccccc21</smiles>

179

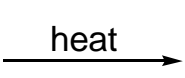

$$
0
$$


Due to the low yields of some of the reactions, namely on the first and last steps, we decided to modify the protocol for the formation of our 2-azidoaminobenzenes. The formation of compounds 152, 197 and 198 was achieved a little differently (Scheme 56). The appropriate o-aminonitroarenes $(59,67$ and 86) were reacted with phthaloyl chloride (187) and pyridine in refluxing toluene to give the corresponding o-phthalamidonitroarenes $(\mathbf{1 8 8}, \mathbf{1 8 9}$ and $\mathbf{1 9 0})$ in excellent yields. Subsequent hydrogenation using $10 \% \mathrm{Pd} / \mathrm{C}$ as the catalyst afforded $o-$ aminophthalamidoarenes 191, 192 and 193 in 88\%, 75\% and 50\% yields, respectively. The hydrogenation reactions seemed to proceed more smoothly and cleaner than the iron reductions discussed above. Compounds 191, 192 and 193 were then subjected to slightly modified diazotization conditions and treatment with sodium azide to give $o$-azidophthalamidoarenes $(194,195$ and 196) in acceptable yields. Also slightly modified were the deprotection reactions. These reactions worked better with longer reaction times and using THF/ethanol as co-solvents. Compounds 152, 197 and 198 were prepared according to this improved method in 98\%, 60\% and $96 \%$ yields, respectively. 
<smiles>[R][X]1cc([R])cc([N+](=O)[O-])c1N</smiles>

$59 \mathrm{R}^{1}=\mathrm{H}, \mathrm{R}^{2}=\mathrm{CH}_{3}, \mathrm{X}=\mathrm{C}$ $67 \mathrm{R}^{1}=\mathrm{CH}_{3}, \mathrm{R}^{2}=\mathrm{H}, \mathrm{X}=\mathrm{C}$ $86 \mathrm{R}^{2}=\mathrm{H}, \mathrm{X}=\mathrm{N}$<smiles>O=C(Cl)c1ccccc1C(=O)Cl</smiles>

187<smiles>[R][X]1cc([R])cc([N+](=O)[O-])c1N1C(=O)c2ccccc2C1=O</smiles>

188 (96\%), $\mathrm{R}^{1}=\mathrm{H}, \mathrm{R}^{2}=\mathrm{CH}_{3}, \mathrm{X}=\mathrm{C}$ $189(88 \%), R^{1}=\mathrm{CH}_{3}, \mathrm{R}^{2}=\mathrm{H}, \mathrm{X}=\mathrm{C}$ $190(96 \%), R^{2}=\mathrm{H}, X=\mathrm{N}$

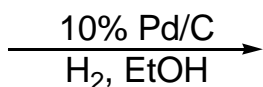<smiles>[R][X]1cc([R])cc(N)c1N1C(=O)c2ccccc2C1=O</smiles>

$191(88 \%), \mathrm{R}^{1}=\mathrm{H}, \mathrm{R}^{2}=\mathrm{CH}_{3}, \mathrm{X}=\mathrm{C}$ $192(75 \%), \mathrm{R}^{1}=\mathrm{CH}_{3}, \mathrm{R}^{2}=\mathrm{H}, \mathrm{X}=\mathrm{C}$ 193 (50\%), $\mathrm{R}^{2}=\mathrm{H}, \mathrm{X}=\mathrm{N}$<smiles>[R][X]1cc([R])cc(N)c1N1C(=O)c2ccccc2C1=O</smiles>

$194(90 \%), \mathrm{R}^{1}=\mathrm{H}, \mathrm{R}^{2}=\mathrm{CH}_{3}, \mathrm{X}=\mathrm{C}$ $195(75 \%), \mathrm{R}^{1}=\mathrm{CH}_{3}, \mathrm{R}^{2}=\mathrm{H}, \mathrm{X}=\mathrm{C}$ $196(60 \%), R^{2}=H, X=N$

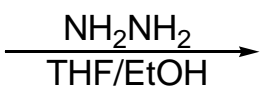

152 (98\%), $\mathrm{R}^{1}=\mathrm{H}, \mathrm{R}^{2}=\mathrm{CH}_{3}, \mathrm{X}=\mathrm{C}$ $197(60 \%), \mathrm{R}^{1}=\mathrm{CH}_{3}, \mathrm{R}^{2}=\mathrm{H}, \mathrm{X}=\mathrm{C}$ $198(96 \%), R^{2}=H, X=N$

With several compounds in hand, it was now possible to examine the scope of the benzimidazole-forming reaction. During the condition optimization process, we tried several approaches. The set of conditions that generally provided the highest benzimidazole yields are as follows: 1.0 equivalent of azide and 1.2 equivalents of aldehyde (added dropwise to avoid 
aldol condensation side products) in refluxing ethanol for $24 \mathrm{~h}$. Shorter reaction times led to lower conversion to benzimidazoles and the isolation of azide starting materials. We also attempted to promote the formation of imines by the addition of glacial acetic acid to the reaction mixture. Generally, the addition of acid led to the rapid decomposition of the azides and, therefore, lower yields of benzimidazoles.

Next, we reacted our previously prepared azides with a variety of aldehydes under these "optimized" reaction conditions. The results of these reactions are summarized in Table 6. Generally, the reactions of azides with 2-methylpropanal (55) and heptanal (83) proceeded smoothly to give 2-alkylbenzimidazoles in moderate yields. However, the reactions of azides with some of the other aldehydes were met with limited success. The reaction of $\mathbf{1 5 2}$ with phenylacetaldehyde (81) (Table 6, Entry 6) gave only 10\% of the benzyl-substituted benzimidazole (202), while 203 was formed in $40 \%$ yield. The product ratio changed somewhat when glacial acetic acid $(25 \mu \mathrm{L})$ was added to the reaction mixture. In this reaction 202 and 203 were formed in 19\% and 30\% yields, respectively. The reaction of $\mathbf{1 5 2}$ with trimethylacetaldehyde (205) (Table 6, Entry 8) formed 5-methyl-2-tert-butylbenzimidazole in $25 \%$ yield. This diminished yield may be attributed to the steric bulk around the electrophilic carbonyl. In the reaction of $\mathbf{1 9 8}$ with 2-methylpropanal (55), the major product is 2,3diaminopyridine (213), presumably from the hydrogen abstraction of the nitrene intermediate. Imidazopyridine $\mathbf{2 1 2}$ is the minor product in this reaction, isolated in only 7\% yield (Table 6 , Entry 12). 
Table 6. ${ }^{\text {a }}$ Synthesis of 2-Alkylbenzimidazoles

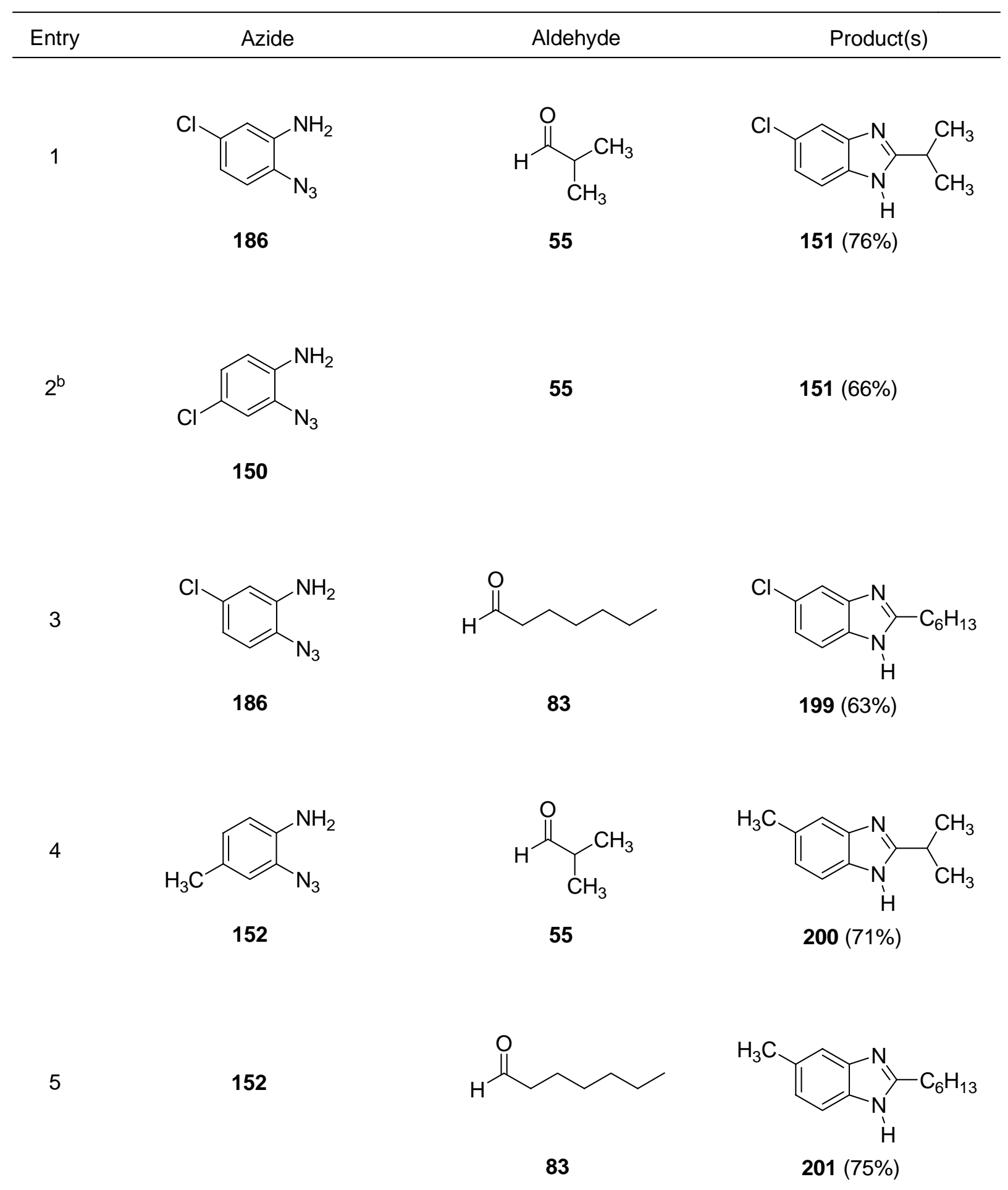


Table 6 (continued)

Entry




\section{Table 6 (continued)}

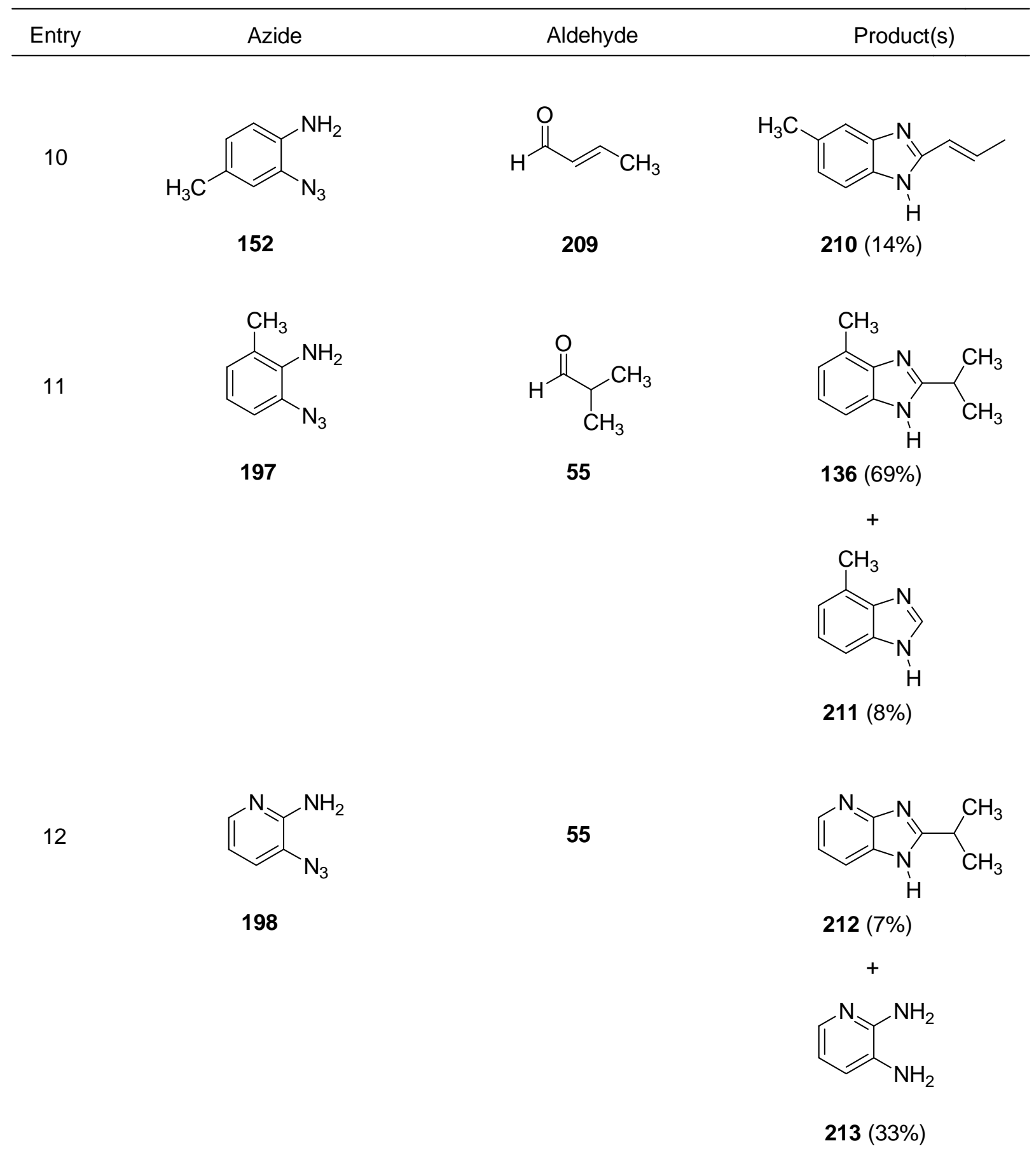

a) General conditions: 1.0 eq azide, 1.2 eq aldehyde, ethanol, reflux, approx. $24 \mathrm{~h}$. b) An additional reaction was performed using 2.75 eq aldehyde and $0.5 \mathrm{~mL}$ acetic acid; yield: 151 (61\%).

c) An additional reaction was performed with $0.025 \mathrm{~mL}$ acetic acid added to reaction mixture; yields: 202 (19\%), 203 (30\%) 
The thermal reactions of 2-azidoaminobenzenes with aldehydes to form benzimidazoles are thought to occur by the mechanism described in Scheme 57. At least initially, the reaction is thought to form an imine from the condensation of an amine and an aldehyde. This is followed by the thermally-driven loss of $\mathrm{N}_{2}$ to give a nitrene. ${ }^{30}$ The imine-nitrene may then react in an electrocyclic fashion followed by spontaneous isomerization to form the benzimidazole. In some of our reactions, benzimidazoles unsubstituted in the 2-position were obtained (Table 6, Entries 6 and 11). The reason for the formation of these products is unclear at this point.

\section{Scheme 57. Proposed Mechanism for the Formation of Benzimidazoles}

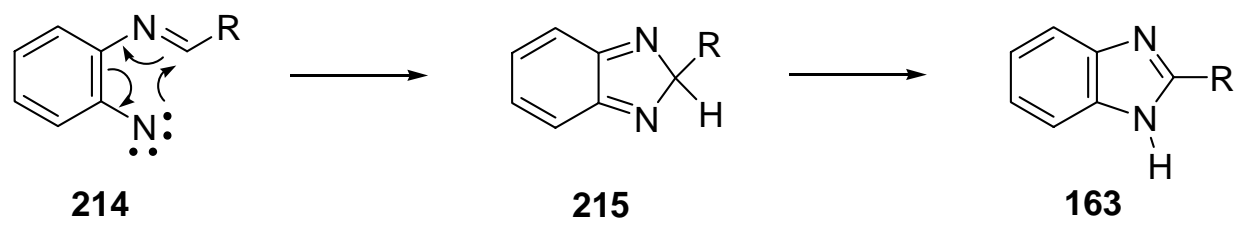

As a study of the mechanism of the formation of benzimidazoles, we attempted to prepare a 2-cyclopropylmethylbenzimidazole. Our thought was that if a radical mechanism existed, one of the intermediates might react in such a way causing the cyclopropyl ring to open. Examination of the product(s) might give us some insight into the structure(s) of the intermediate(s). A slightly different procedure was employed in the synthesis of 2cyclopropylmethyl-5-methylbenzimidazole (217) (Scheme 58). First, 2-cyclopropylethanol (216) was oxidized to the aldehyde with pyridinium chlorochromate. Without purification, to the aldehyde solution was added 2-azido-4-methylaminobenzene (152) and the mixture was heated at $100{ }^{\circ} \mathrm{C}$ in a sealed reaction vessel for $24 \mathrm{~h}$. This method, gave only benzimidazole 217 in $11 \%$ yield. No other products were recovered and so no insight into the mechanism was gained. 


\section{Scheme 58. Synthesis of 217}

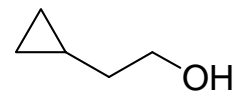

216
1) $\mathrm{PCC}, \mathrm{CH}_{2} \mathrm{Cl}_{2}$, ambient temp.

2) $152, \mathrm{CH}_{2} \mathrm{Cl}_{2}, 100^{\circ} \mathrm{C}$

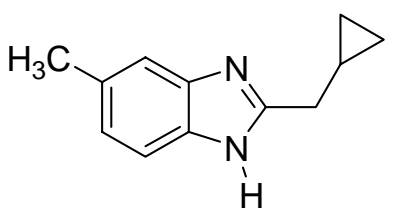

$217(11 \%)$

\section{Conclusions}

We have developed a novel route to 2-alkylbenzimidazoles from the condensationcyclization reaction of 2-azidoaminobenzenes and aldehydes. The best results were achieved when 2-methylpropanal or heptanal was used. Other aldehydes gave considerably lower yields of benzimidazoles. The reaction can also be expanded to include the pyridine moiety; however, the yield was greatly diminished. We have also proposed a mechanism for the transformations to occur involving a nitrene intermediate. 


\section{Part V}

\section{Synthesis of Other Heterocyclic Ring Systems via $\mathrm{N}$-Heteroannulation Reactions}

\section{Synthesis of Alloxazines}

The family of compounds known as the alloxazines is characterized by the ring system shown in Figure 4. Many members of this class of compounds exhibit a wide range of biological activity. ${ }^{55}$ One of the more notable biologically active alloxazines is the nutritional factor riboflavine. It was our desire to expand the palladium-catalyzed $N$-heteroannulation methodology to include the synthesis of alloxazines.

Figure 4. Alloxazine and Riboflavine<smiles>O=c1[nH]c(=O)c2nc3ccccc3nc2[nH]1</smiles>

alloxazine<smiles>Cc1cc2nc3c(=O)[nH]c(=O)nc-3n(CC(O)(O)C(O)C(C)(O)CO)c2cc1C</smiles>

riboflavine

In order to test our reaction conditions, it was necessary to synthesize the cyclization precursors. Cyclization precursors would generally have to fit the model shown in Figure 5. We attempted many methods in our quest to synthesize compounds of this type; however, in the end, we were unable to succeed at our task. Various attempted procedures are presented. 


\section{Figure 5. General Structure of an Alloxazine Precursor}

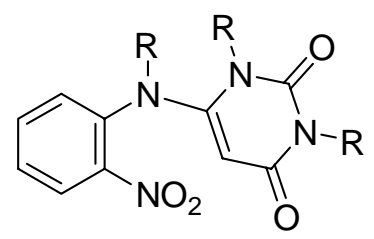

cyclization precursor

First we attempted to prepare a cyclization precursor by various reactions of 2nitroaminobenzene (52) and 6-halouracils (Scheme 59). The details of these reactions are summarized in Table 7. Addition-elimination type reactions were attempted with $\mathbf{5 2}$ and 6chlorouracil (218) using two different solvents, 1-butanol and chloroform (Table 7, Entries 1 and 2). Neither reaction produced the desired product. Next, we attempted the coupling by following a literature protocol using $N, N$-dimethylaminobenzene and acetic acid. ${ }^{56}$ We tried this reaction using the chloro, bromo and iodo-substituted uracil (Table 7, Entries 3, 4 and 5). None of these reactions were successful. Finally, a copper-promoted coupling was attempted according to a literature procedure (Table 7, Entry 6). ${ }^{57}$ In this example, the coupling of 52 and 218 failed to give the desired result. 
Scheme 59. General Reaction of 2-Nitroaminobenzene and 6-Halouracils

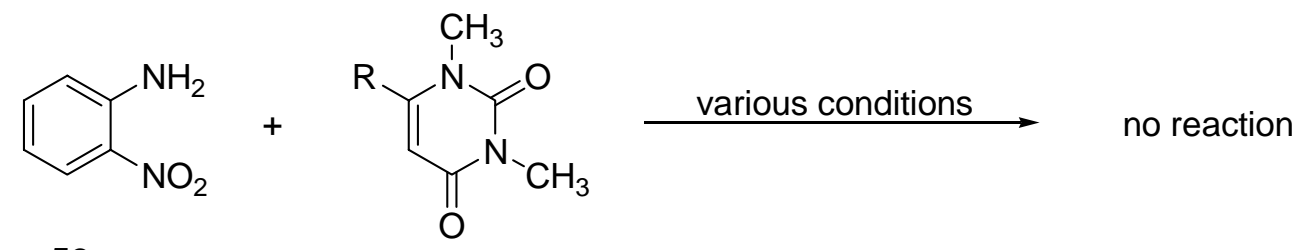

52

Table 7. Conditions for the Reactions of 2-Nitroaminobenzene and 6-Halouracils

\begin{tabular}{cll}
\hline Entry & \\
& $\mathbf{2 1 8}, \mathrm{R}=\mathrm{Cl}$ & \\
\hline 1 & $\mathbf{2 1 8}, \mathrm{R}=\mathrm{Cl}$ & 1-butanol, pyridine, reflux \\
3 & $\mathbf{2 1 8}, \mathrm{R}=\mathrm{Cl}$ & $\mathrm{CHCl}_{3}$, pyridine, reflux \\
4 & $\mathbf{2 1 9}, \mathrm{R}=\mathrm{Br}$ & $\mathrm{PhN}\left(\mathrm{CH}_{3}\right)_{2}, \mathrm{AcOH}, 180^{\circ} \mathrm{C}$ \\
5 & $\mathbf{2 2 0}, \mathrm{R}=\mathrm{PN}\left(\mathrm{CH}_{3}\right)_{2}, \mathrm{AcOH}, 180^{\circ} \mathrm{C}$ \\
6 & $\mathbf{2 1 8}, \mathrm{R}=\mathrm{Cl}$ & $\mathrm{PhN}\left(\mathrm{CH}_{3}\right)_{2}, \mathrm{AcOH}, 180^{\circ} \mathrm{C}$ \\
& $\mathrm{Cu}, \mathrm{Li}_{2} \mathrm{CO}_{3}, \mathrm{DMSO}, 150^{\circ} \mathrm{C}$ \\
\hline
\end{tabular}

Next, a series of palladium-catalyzed reactions were attempted according to literature protocols (Scheme 60). ${ }^{58}$ The details of these reactions are summarized in Table 8. The reaction of 2-nitroaminobenzene (52) with 6-iodouracil (220) under these conditions failed to give the desired product (Table 8, Entry 1). When we attempted the coupling using 6-aminouracil (222) and aryl halides, the reactions failed as well (Table 8, Entries 2 and 3). 


\section{Scheme 60. General Palladium-catalyzed Reactions to Form Cyclization Precursors}

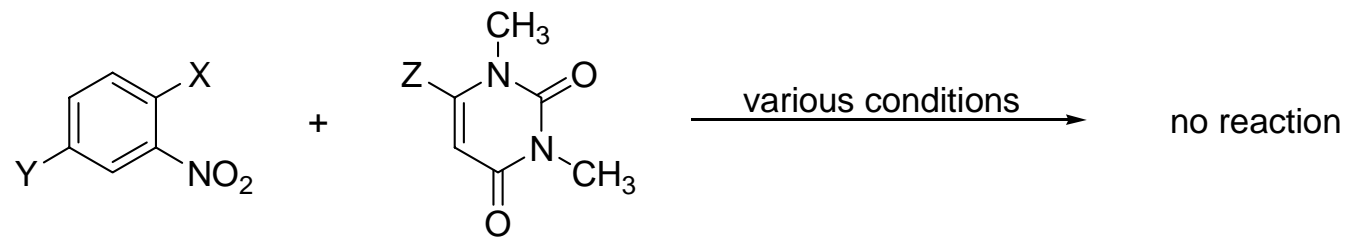

Table 8. Conditions for the Palladium-catalyzed Reactions

\begin{tabular}{|c|c|c|c|}
\hline Entry & $\overbrace{}^{x}$ & $\mathrm{I}_{\mathrm{I}}^{\mathrm{C} \mathrm{H}_{3}}=\mathrm{O}$ & Conditions \\
\hline 1 & 52, $\mathrm{X}=\mathrm{NH}_{2}, \mathrm{Y}=\mathrm{H}$ & $220, Z=1$ & $\mathrm{Pd}(\mathrm{dba})_{2}, \mathrm{BINAP}, \mathrm{KOt}-\mathrm{Bu}$, toluene, $80^{\circ} \mathrm{C}$ \\
\hline 2 & 221, $X=I, Y=H$ & 222, $\mathrm{Z}=\mathrm{NH}_{2}$ & $\mathrm{Pd}(\mathrm{OAc})_{2}, \mathrm{BINAP}, \mathrm{Cs}_{2} \mathrm{CO}_{3}$, toluene, $80^{\circ} \mathrm{C}$ \\
\hline 3 & 223, $\mathrm{X}=\mathrm{Br}, \mathrm{Y}=\mathrm{OCH}_{3}$ & 222, $\mathrm{Z}=\mathrm{NH}_{2}$ & $\mathrm{Pd}(\mathrm{OAc})_{2}, \mathrm{BINAP}, \mathrm{Cs}_{2} \mathrm{CO}_{3}$, toluene, $80^{\circ} \mathrm{C}$ \\
\hline
\end{tabular}

It was necessary to synthesize three different 6-halouracils for the previously described coupling reactions. Scheme 61 describes the syntheses of 6-chlorouracil (218), 6-iodouracil (220) and 6-bromouracil (219). Compound 218 was prepared by the reaction of 1,3dimethylbarbituric acid (224) with phosphorus oxychloride in 78\% yield. Compound 220 was prepared in 64\% yield from the reaction of $\mathbf{2 1 8}$ and sodium iodide. This reaction was performed in a sealed pressure tube in acetone at $120^{\circ} \mathrm{C}$. The reaction of 1,3-dimethylbarbituric acid (224) with phosphorus tribromide gave compound 219 in 33\% yield. 


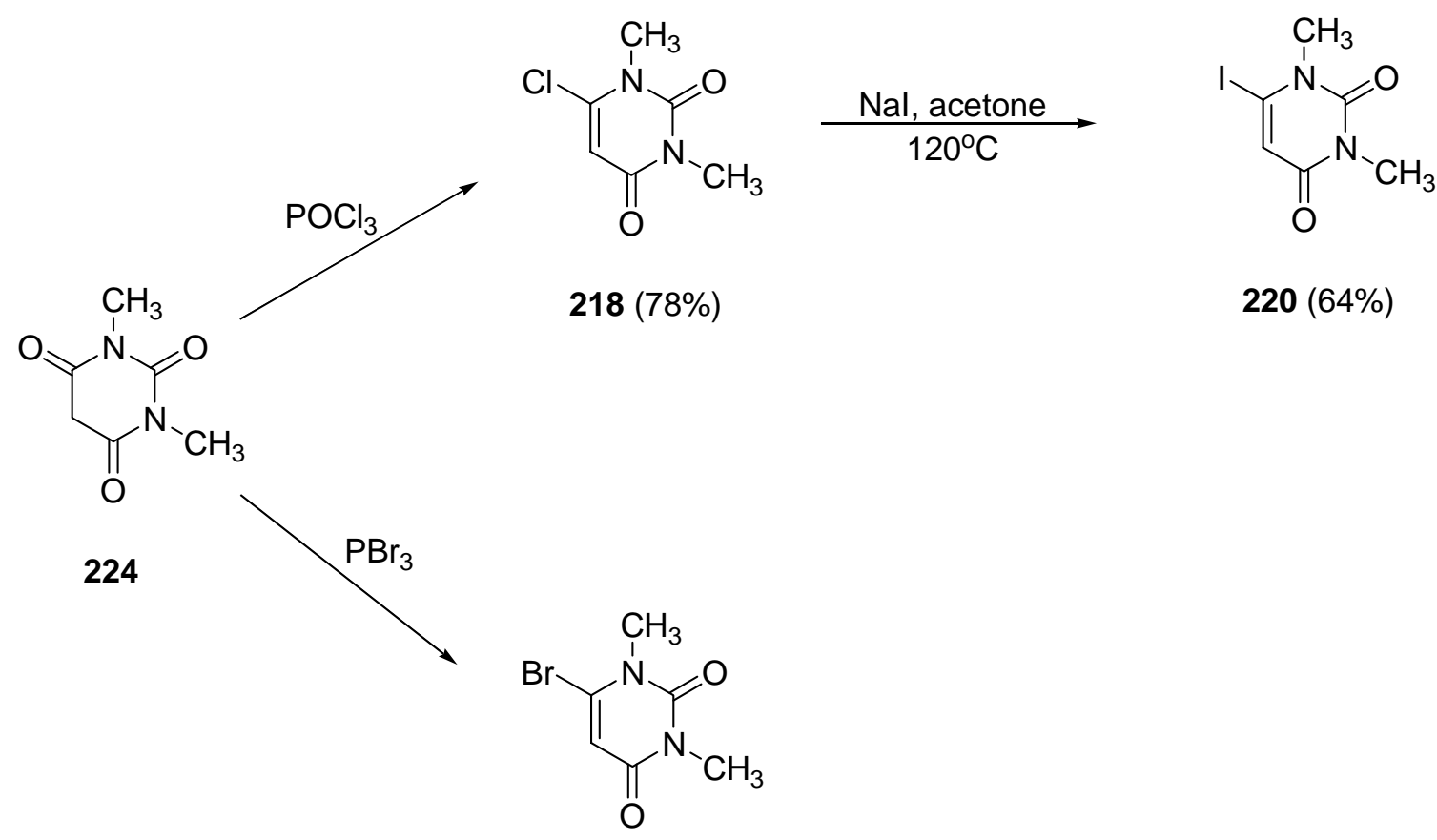

$219(33 \%)$

The synthesis of cyclization precursors was attempted by a few other methods, as well. Scheme 62 describes three such methods. First, it was thought that the reaction of 2nitroaminobenzene (52) and 1,3-dimethylbarbituric acid (224) would produce the desired product by the condensation of the amino group and one of the less hindered carbonyls. This reaction, however, failed to give the product. The reaction of 2-nitroaminobenzene (52) and 6aminouracil (222) under acidic conditions was thought would proceed through an additionelimination pathway and result in the formation of the desired product and ammonia. This reaction, too, failed. Finally, we proposed that the reaction of 2-azidonitrobenzene (131) with triphenylphosphine would form the corresponding iminophosphorane. This species would then react in an aza-Wittig fashion with one of the less hindered carbonyls to form the desired 
compound. When the reaction was performed in tetrahydrofuran (THF), the only product isolated from this sequence was 2-nitroaminobenzene (52) in 94\% yield. However, when diethyl ether was used for the formation of the iminophosphorane, then $\mathrm{CHCl}_{3}$ for the aza-Wittig, no reaction occurred.

\section{Scheme 62. Other Reactions to Form Cyclization Precursors}
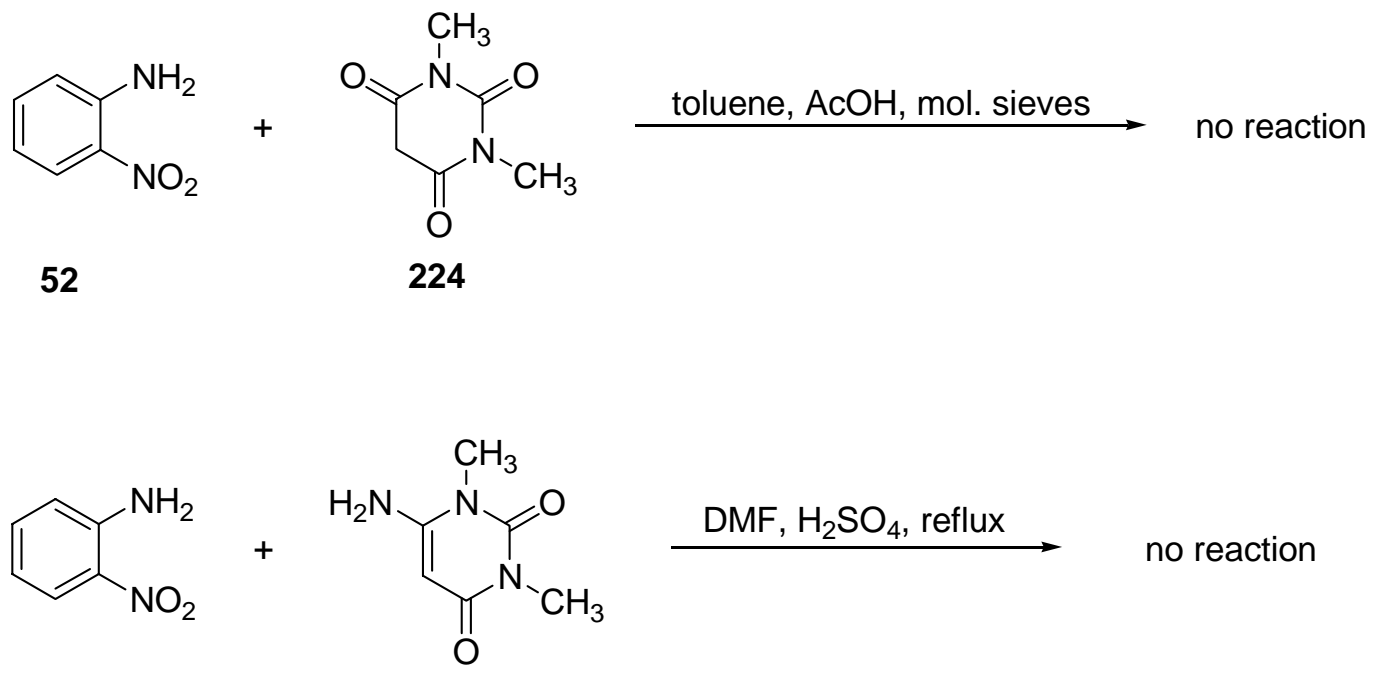

52

$$
222
$$<smiles>Nc1ccccc1[N+](=O)[O-]</smiles>

131<smiles>CN1C(=O)CC(=O)N(C)C1=O</smiles>

224<smiles>Cc1ccccc1[N+](=O)[O-]</smiles>

$52(94 \%)$

\section{Synthesis of an Indole-fused Pyrimidine Derivative}

Heterocyclic compounds having the general structure shown in Figure 6 are known to exhibit physiological properties such as blood sugar-lowering activity. ${ }^{59}$ It was our desire to 
explore the possibility of preparing such compounds using our palladium-catalyzed $\mathrm{N}$ heteroannulation method.

\section{Figure 6. General Structure of an Indole-fused Pyrimidine Derivative}

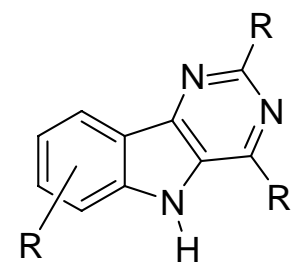

indole-fused pyrimidine derivatives

In order to test the reaction, we first needed to synthesize an appropriate cyclization precursor. We chose to prepare our precursor via a Stille coupling of tributyl(2nitrophenyl)stannane (225) and 6-iodouracil (220) (Scheme 63). Aryl stannane 225 was previously synthesized in our labs according to a literature procedure. ${ }^{60}$ The reaction of $\mathbf{2 2 5}$ and 220 in the presence of $\mathrm{PdCl}_{2}(\mathrm{PhCN})_{2}, \mathrm{Ph}_{3} \mathrm{As}$ and $\mathrm{CuI}$ in $\mathrm{N}$-methylpyrrolidinone (NMP) at $80{ }^{\circ} \mathrm{C}$ gave the desired coupling product 226 and homocoupling product 227 in $48 \%$ and $36 \%$ yields, respectively. 
<smiles>CCCCc1ccccc1[N+](=O)[O-]</smiles>

225<smiles>Cn1c(I)cc(=O)n(C)c1=O</smiles>

220<smiles>Cn1c(-c2ccccc2[N+](=O)[O-])cc(=O)n(C)c1=O</smiles>

$226(48 \%)$<smiles>O=[N+]([O-])c1ccccc1-c1ccccc1[N+](=O)[O-]</smiles>

$227(36 \%)$

With compound 226 in hand, we attempted the cyclization according to our method. The reaction of 226 in the presence of $\operatorname{Pd}(\mathrm{dba})_{2}$, dppp, phen and carbon monoxide in $\mathrm{DMF}$ at $70{ }^{\circ} \mathrm{C}$ gave the desired cyclization product 228 in 9\% yield (Scheme 64).

\section{Scheme 64. Synthesis of 228}<smiles>Cn1c(-c2ccccc2[N+](=O)[O-])cc(=O)n(C)c1=O</smiles>

226

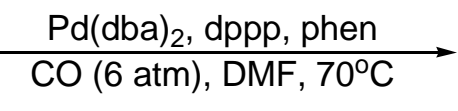

$\underset{\mathrm{CO}(\mathrm{dba})_{2}, \mathrm{dppp} \text {, phen }}{\mathrm{CO} \text { atm }), \mathrm{DMF}, 70^{\circ} \mathrm{C}}$<smiles>Cn1c(=O)c2[nH]c3ccccc3c2n(C)c1=O</smiles>

$228(9 \%)$

\section{Conclusions}

Despite numerous attempts and the use of many different methods we were unsuccessful in the synthesis of alloxazine precursors. It is our belief that if this type of compound can be prepared that it will undergo cyclization under our conditions to form the desired alloxazine. More research is planned in this area. 
We were able to synthesize an interesting heterocyclic compound that is analogous to compounds known to exhibit biological activity. This compound was synthesized in relatively low yield; however, with adjustments to the protocol, it is our belief that our method of cyclization can be expanded and become a viable synthetic route to compounds of this type. This is an area that will be researched further in our labs. 


\section{Part VI}

\section{Experimental Section}

\section{General Procedures}

All NMR spectra were determined in $\mathrm{CDCl}_{3}$ at $270 \mathrm{MHz}\left({ }^{1} \mathrm{H} \mathrm{NMR}\right)$ and $67.5 \mathrm{MHz}\left({ }^{13} \mathrm{C}\right.$ NMR) unless otherwise noted. The chemical shifts are expressed in $\delta$ values relative to $\left(\mathrm{CH}_{3}\right)_{4} \mathrm{Si}$ $\left(0.00,{ }^{1} \mathrm{H}\right.$ and $\left.{ }^{13} \mathrm{C}\right)$ or $\mathrm{CDCl}_{3}\left(7.26,{ }^{1} \mathrm{H}\right.$ and $\left.77.00,{ }^{13} \mathrm{C}\right)$ internal standards. ${ }^{1} \mathrm{H}-{ }^{1} \mathrm{H}$ coupling constants are reported as calculated from spectra; thus, a slight difference in $J_{\mathrm{a}, \mathrm{b}}$ and $J_{\mathrm{b}, \mathrm{a}}$ is usually obtained. Results of APT (attached proton test) ${ }^{13} \mathrm{C}$ NMR experiments are shown in parentheses, where relative to $\mathrm{CDCl}_{3},(-)$ denotes $\mathrm{CH}_{3}$ or $\mathrm{CH}$ and $(+)$ denotes $\mathrm{CH}_{2}$ or $\mathrm{C}$.

Benzene, toluene and diethyl ether were distilled from sodium benzophenone ketyl prior to use. Pyridine, triethylamine, hexanes, acetonitrile, ethyl acetate and dichloromethane were distilled from calcium hydride. Chemicals prepared according to literature procedures have been referenced the first time they are used; all other reagents were obtained from commercial sources and used as received. Silica gel (200-400 mesh) was used for flash chromatography. Solvents were removed using a rotary evaporator at water aspirator pressure unless otherwise noted. Infrared (IR) spectra were recorded using $\mathrm{NaCl}$ plates. Elemental analyses were performed by Atlantic Microlab, Inc., Norcross, GA. High Resolution Mass Spectra (HRMS) were performed at the University of California Riverside Mass Spectrometry Center. 


\section{Experimental Details}

\section{Methyl 2-bromomethyl-3-nitrobenzoate ${ }^{7}$ (18).}

To a solution of methyl 2-methyl-3-nitrobenzoate (17) (9.60 g, $49.1 \mathrm{mmol})$ and benzoyl peroxide $(0.60 \mathrm{~g}, 2.6 \mathrm{mmol})$ in $\mathrm{CCl}_{4}(100 \mathrm{~mL})$ was added dropwise a solution of bromine $(3.0$ $\mathrm{mL}, 58.6 \mathrm{mmol})$ dissolved in $\mathrm{CCl}_{4}(20 \mathrm{~mL})$ with stirring. The mixture was illuminated with a 100 Watt flood lamp and was heated at reflux for $24 \mathrm{~h}$. The reaction was diluted with $\mathrm{CH}_{2} \mathrm{Cl}_{2}$ $(50 \mathrm{~mL})$ and washed with $\mathrm{NaHCO}_{3}$ (saturated, aqueous, $3 \mathrm{X} 50 \mathrm{~mL}$ ). The organic phase was dried $\left(\mathrm{MgSO}_{4}\right)$, filtered and concentrated. Compound 18 (13.46 g, $\left.49.1 \mathrm{mmol}, 100 \%\right)$ was obtained as pale yellow crystals.

\section{(2-Carbomethoxy-6-nitrobenzyl)triphenylphosphonium bromide ${ }^{7}$ (19).}

To a solution of $\mathbf{1 8}(13.50 \mathrm{~g}, 49.1 \mathrm{mmol})$ in $\mathrm{CHCl}_{3}(150 \mathrm{~mL})$ was added triphenylphosphine $(14.80 \mathrm{~g}, 56.5 \mathrm{mmol})$ with stirring. The reaction was heated at reflux for $2 \mathrm{~h}$. The resulting orange solution was then poured into diethyl ether (anhydrous, $400 \mathrm{~mL}$ ) and a white precipitate formed. After cooling in the freezer (approx. $\left.-20{ }^{\circ} \mathrm{C}\right)$ for $1 \mathrm{~h},(2$-carbomethoxy6-nitrobenzyl)triphenylphosphonium bromide (19) was collected by filtration and used without further purification in the next procedure.

\section{Methyl 2-ethenyl-3-nitrobenzoate ${ }^{7}$ (20).}

Paraformaldehyde (20.00 g, $667 \mathrm{mmol})$ was placed in a $250 \mathrm{~mL}$, 2-necked, roundbottomed flask. An argon inlet was connected to one of the necks. The other neck was connected to a $1 \mathrm{~L}, 2$-necked, round-bottomed flask via Tygon tubing ( $2 \mathrm{~cm} \mathrm{id}$ ) and two male 
$24 / 40$ joints. In the $1 \mathrm{~L}$ flask, the crude (2-carbomethoxy-6-nitrobenzyl)triphenylphosphonium bromide from the previous procedure was dissolved in $\mathrm{CH}_{2} \mathrm{Cl}_{2}(500 \mathrm{~mL})$. A glass tube was attached to the Tygon tubing such that the end extended several $\mathrm{cm}$ into the solution. Triethylamine $(30.0 \mathrm{~mL}, 215 \mathrm{mmol})$ was added to the $1 \mathrm{~L}$ flask and resulted in the immediate formation of a deep blue/purple solution; a condenser was attached to the second neck of the flask. Argon was then passed over the paraformaldehyde so that a steady stream of gas was constantly bubbling through the purple ylide solution. The paraformaldehyde was then heated to $160^{\circ} \mathrm{C}$ in order to generate formaldehyde which flowed through the solution. Upon completion of the addition of formaldehyde, the purple color of the ylide slowly changed to brown over a period of 1-2 $\mathrm{h}$. The resulting solution was poured into hexanes $(500 \mathrm{~mL})$ and the resulting solid (triphenylphosphine oxide) was removed by filtration. The filtrate was concentrated and the crude product was purified by flash chromatography (hexanes/EtOAc, 8:2) to give $\mathbf{2 0}$ (7.30 g, $35.0 \mathrm{mmol}, 71 \%$ over 2 steps) as a white solid.

\section{Methyl indole-4-carboxylate ${ }^{7,10}$ (21).}

To a solution of $20(4.10 \mathrm{~g}, 20.0 \mathrm{mmol})$ and triphenylphoshine $(1.30 \mathrm{~g}, 4.8 \mathrm{mmol})$ dissolved in acetonitrile $(100 \mathrm{~mL})$ in a $300 \mathrm{~mL}$ glass liner of a stainless steel reaction vessel was added palladium diacetate $(269 \mathrm{mg}, 1.2 \mathrm{mmol})$. The glass liner was placed in the reaction vessel and the vessel was flushed 3 times with $\mathrm{CO}$. The reaction was heated and stirred at $90{ }^{\circ} \mathrm{C}$ under $\mathrm{CO}(6 \mathrm{~atm})$ for $27 \mathrm{~h}$. The reaction mixture was filtered through Celite and washed with $\mathrm{CH}_{2} \mathrm{Cl}_{2}$. The filtrate was concentrated and the product was purified by flash chromatography (hexanes $/ \mathrm{CH}_{2} \mathrm{Cl}_{2}, 7: 3$, then 1:1) to give 21 (3.06 g, $17.5 \mathrm{mmol}, 87 \%$ ) as a pale yellow solid. 
2-Nitro- $N$-[(4-nitrophenyl)methylene]benzenamine ${ }^{61}$ (54).

To a solution of 2-nitroaminobenzene (52) (502 mg, $3.6 \mathrm{mmol})$ and 4-nitrobenzaldehyde (53) (552 mg, $3.7 \mathrm{mmol}$ ) dissolved in benzene (anhydrous, $10 \mathrm{~mL}$ ) under argon atmosphere was added $4 \AA$ molecular sieves ( $3 \mathrm{~g}$; the molecular sieves were charged by heating to $120^{\circ} \mathrm{C}$ under vacuum overnight and then stored under argon atmosphere). The reaction proceeded at ambient temperature without stirring for $23 \mathrm{~h}$. The molecular sieves were removed by filtration and then rinsed with $\mathrm{CH}_{2} \mathrm{Cl}_{2}$. The filtrate was concentrated and the product was recrystallized from EtOAc to give 54 (532 mg, $1.96 \mathrm{mmol}, 54 \%$ ) as a fluffy yellow solid: ${ }^{1} \mathrm{H}$ NMR $\delta 8.51(\mathrm{~s}, 1 \mathrm{H})$, $8.36(\mathrm{~d}, J=8.7 \mathrm{~Hz}, 2 \mathrm{H}), 8.09(\mathrm{~d}, J=8.7 \mathrm{~Hz}, 2 \mathrm{H}), 8.02(\mathrm{dd}, J=8.1$ and $1.4 \mathrm{~Hz}, 1 \mathrm{H}), 7.64(\mathrm{dt}, J$ $=7.9$ and $1.4 \mathrm{~Hz}, 1 \mathrm{H}), 7.38(\mathrm{dt}, J=7.8$ and $1.2 \mathrm{~Hz}, 1 \mathrm{H}), 7.08(\mathrm{~d}, J=7.9 \mathrm{~Hz}, 1 \mathrm{H}) ;{ }^{13} \mathrm{C} \mathrm{NMR} \delta$ $159.3(-), 149.6(+), 145.8(+), 142.8(+), 140.5(+), 134.1(-), 129.9(-), 126.3(-), 124.8(-)$, $124.0(-), 120.5(-)$

\section{2-Nitro- $N$-[(2-methyl)-1-propenyl]benzenamine (56).}

To a solution of 2-nitroaminobenzene (52) (502 mg, $3.6 \mathrm{mmol})$ and 2-methylpropanal (55) $(0.33 \mathrm{~mL}, 3.6 \mathrm{mmol})$ dissolved in benzene (anhydrous, $10 \mathrm{~mL}$ ) at $-20{ }^{\circ} \mathrm{C}$ under argon atmosphere was added $4 \AA$ molecular sieves ( $4 \mathrm{~g}$; the molecular sieves were charged by heating to $120^{\circ} \mathrm{C}$ under vacuum overnight and then stored under argon atmosphere). The reaction proceeded at $-20^{\circ} \mathrm{C}$ for 14 days. The molecular sieves were removed by filtration and then rinsed with $\mathrm{CH}_{2} \mathrm{Cl}_{2}$. The filtrate was concentrated and the product was purified by flash chromatography (hexanes/EtOAc, 95:5) to give 56 (510 mg, $2.7 \mathrm{mmol}, 73 \%$ ) as a red solid: $\mathrm{mp}$ $38-40^{\circ} \mathrm{C} ;{ }^{1} \mathrm{H}$ NMR $\delta 9.64($ br s, $1 \mathrm{H}), 8.18(\mathrm{dd}, J=8.4$ and $1.5 \mathrm{~Hz}, 1 \mathrm{H}), 7.44(\mathrm{dt}, J=8.6$ and 1.5 $\mathrm{Hz}, 1 \mathrm{H}), 7.05(\mathrm{~d}, J=8.7 \mathrm{~Hz}, 1 \mathrm{H}), 6.70(\mathrm{dt}, J=6.9$ and $1.2 \mathrm{~Hz}, 1 \mathrm{H}), 6.27(\mathrm{dm}, J=8.2$ and 1.2 
$\mathrm{Hz}, 1 \mathrm{H}), 1.82$ (s, $3 \mathrm{H}), 1.80(\mathrm{~s}, 3 \mathrm{H}) ;{ }^{13} \mathrm{C} \mathrm{NMR} \delta 141.3(+), 136.0(-), 131.6(+), 126.7(-)$, $118.4(+), 118.2(-), 116.3(-), 114.1(-), 22.5(-), 16.6(-) ;$ IR (neat) 1639, 1577, $1208 \mathrm{~cm}^{-1}$; HRMS (EI) calc. for $\mathrm{C}_{10} \mathrm{H}_{12} \mathrm{~N}_{2} \mathrm{O}_{2}$ 192.0899, found 192.0899 .

\section{1,2-Dihydro-2,2-dimethylquinoxaline ${ }^{62}$ (57) and 3,4-dihydro-3,3-dimethyl-2- quinoxalinone $^{63}(58)$.}

2-Nitro- $N$-[(2-methyl)-1-propenyl]benzenamine (56) (102 mg, $0.53 \mathrm{mmol}), \operatorname{Pd}(\mathrm{dba})_{2}(20$ $\mathrm{mg}, 0.035 \mathrm{mmol}), 1$,3-bis(diphenylphosphino)propane (dppp) (15 mg, $0.036 \mathrm{mmol}$ ) and acetonitrile $(5 \mathrm{~mL})$ were combined in a threaded pressure tube fitted with a pressure head. The tube was flushed 3 times with $\mathrm{CO}$. The reaction was heated and stirred at $70{ }^{\circ} \mathrm{C}$ under $\mathrm{CO}(4$ atm) for $20 \mathrm{~h}$. The reaction mixture was filtered through Celite and washed with $\mathrm{CH}_{2} \mathrm{Cl}_{2}$. The filtrate was concentrated and the product was purified by flash chromatography (hexanes/EtOAc, 7:3) to give 57 (60 mg, $0.375 \mathrm{mmol}, 71 \%)$ and 58 (10 mg, $0.057 \mathrm{mmol}, 11 \%)$ as off-white solids.

\section{4-Methyl-2-nitro- $N$-[(2-methyl)-1-propenyl]benzenamine (60).}

The same procedure as described for 56 was repeated except that a mixture of 4-methyl2-nitroaminobenzene (59) (501 mg, $3.3 \mathrm{mmol})$, 2-methylpropanal (55) (0.30 mL, $3.3 \mathrm{mmol})$, benzene (anhydrous, $10 \mathrm{~mL}$ ) and $4 \AA$ molecular sieves $(4 \mathrm{~g})$ at ambient temperature was reacted for $20 \mathrm{~h}$. Purification by flash chromatography (hexanes/EtOAc, 95:5) gave 60 (601 mg, 2.9 mmol, 89\%) as a red solid: $\mathrm{mp} 53-55^{\circ} \mathrm{C} ;{ }^{1} \mathrm{H}$ NMR $\delta 9.56$ (br s, $\left.1 \mathrm{H}\right), 7.98(\mathrm{~s}, 1 \mathrm{H}), 7.27(\mathrm{dd}, J=$ 8.6 and $2.2 \mathrm{~Hz}, 1 \mathrm{H}), 6.96(\mathrm{~d}, J=8.9 \mathrm{~Hz}, 1 \mathrm{H}), 6.27(\mathrm{dm}, J=9.6 \mathrm{~Hz}, 1 \mathrm{H}), 2.28(\mathrm{~s}, 3 \mathrm{H}), 1.81(\mathrm{~s}$, $3 \mathrm{H}), 1.79(\mathrm{~s}, 3 \mathrm{H}) ;{ }^{13} \mathrm{C}$ NMR $\delta 139.4(+), 137.5(-), 131.1(+), 126.0(+), 125.8(-), 118.4(-)$, 
$117.4(+), 114.1(-), 22.4(-), 19.9(-), 16.6(-)$; IR (neat) 1632, 1572, 1519, 1341, $1166 \mathrm{~cm}^{-1}$;

Anal. calcd for $\mathrm{C}_{11} \mathrm{H}_{14} \mathrm{~N}_{2} \mathrm{O}_{2}$ : C, 64.06; $\mathrm{H}, 6.84$, found: $\mathrm{C}, 64.18 ; \mathrm{H}, 6.70$.

\section{4-Methoxy-2-nitro- $N$-[(2-methyl)-1-propenyl]benzenamine (62).}

The same procedure as described for $\mathbf{5 6}$ was repeated except that a mixture of 4methoxy-2-nitroaminobenzene (61) (506 mg, $3.0 \mathrm{mmol})$, 2-methylpropanal (55) (0.30 mL, 3.3 mmol), benzene (anhydrous, $10 \mathrm{~mL}$ ) and $4 \AA$ molecular sieves ( $4 \mathrm{~g}$ ) at ambient temperature was reacted for $20 \mathrm{~h}$. Purification by flash chromatography (hexanes/EtOAc, 98:2) gave 62 (635 mg, $2.9 \mathrm{mmol}, 95 \%)$ as a red solid: $\mathrm{mp} 57-59^{\circ} \mathrm{C} ;{ }^{1} \mathrm{H} \mathrm{NMR} \delta 9.61(\mathrm{~d}, J=8.2 \mathrm{~Hz}, 1 \mathrm{H}), 7.60(\mathrm{~d}, J=$ $2.7 \mathrm{~Hz}, 1 \mathrm{H}), 7.15(\mathrm{dd}, J=9.4$ and $3.0 \mathrm{~Hz}, 1 \mathrm{H}), 7.02(\mathrm{~d}, J=9.4 \mathrm{~Hz}, 1 \mathrm{H}), 6.27(\mathrm{dm}, J=9.6 \mathrm{~Hz}$,

$1 \mathrm{H}), 3.81(\mathrm{~s}, 3 \mathrm{H}), 1.81(\mathrm{~s}, 3 \mathrm{H}), 1.79(\mathrm{~s}, 3 \mathrm{H}) ;{ }^{13} \mathrm{C} \mathrm{NMR} \delta 150.2(+), 137.0(+), 130.6(+), 127.1$ $(-), 118.5(-), 117.5(+), 115.5(-), 106.5(-), 55.6(-), 22.4(-), 16.6(-)$; IR (neat) 1638, 1520, 1162, $1122 \mathrm{~cm}^{-1}$; Anal. calcd for $\mathrm{C}_{11} \mathrm{H}_{14} \mathrm{~N}_{2} \mathrm{O}_{3}: \mathrm{C}, 59.45 ; \mathrm{H}, 6.35$, found: $\mathrm{C}, 59.18 ; \mathrm{H}, 6.42$.

\section{4-Chloro-2-nitro- $N$-[(2-methyl)-1-propenyl]benzenamine (64).}

The same procedure as described for $\mathbf{5 6}$ was repeated except that a mixture of 4-chloro-2nitroaminobenzene (63) (505 mg, 2.9 mmol), 2-methylpropanal (55) (0.27 mL, $2.9 \mathrm{mmol}$ ), benzene (anhydrous, $10 \mathrm{~mL}$ ) and $4 \AA$ molecular sieves ( $4 \mathrm{~g}$ ) at ambient temperature was reacted for $26 \mathrm{~h}$. No further purification was needed and $64(660 \mathrm{mg}, 2.9 \mathrm{mmol}, 100 \%)$ was obtained as a red solid: $\mathrm{mp} 109-110^{\circ} \mathrm{C} ;{ }^{1} \mathrm{H}$ NMR $\delta 9.58(\mathrm{~d}, J=8.2 \mathrm{~Hz}, 1 \mathrm{H}), 8.17(\mathrm{~d}, J=2.7 \mathrm{~Hz}, 1 \mathrm{H}), 7.38$ (dd, $J=9.2$ and $2.5 \mathrm{~Hz}, 1 \mathrm{H}), 7.01(\mathrm{~d}, J=9.1 \mathrm{~Hz}, 1 \mathrm{H}), 6.22(\mathrm{dm}, J=9.6$ and $1.2 \mathrm{~Hz}, 1 \mathrm{H}), 1.82$ (s, $3 \mathrm{H}), 1.79(\mathrm{~s}, 3 \mathrm{H}) ;{ }^{13} \mathrm{C}$ NMR $\delta 140.0(+), 136.2(-), 131.5(+), 125.9(-), 121.2(+), 119.9(+)$, 
118.0 (-), 115.7 (-), 22.5 (-), 16.8 (-); IR (neat) 1641, 1198, $1124 \mathrm{~cm}^{-1}$; Anal. Calc for $\mathrm{C}_{10} \mathrm{H}_{11} \mathrm{ClN}_{2} \mathrm{O}_{2}$ : C, 52.99; H, 4.89, found: $\mathrm{C}, 53.08 ; \mathrm{H}, 4.82$.

\section{5-Chloro-2-nitro- $N$-[(2-methyl)-1-propenyl]benzenamine (66).}

The same procedure as described for $\mathbf{5 6}$ was repeated except that a mixture of 5-chloro-2nitroaminobenzene (65) (504 mg, 2.9 mmol), 2-methylpropanal (55) (0.30 mL, $3.3 \mathrm{mmol})$, $\mathrm{CH}_{2} \mathrm{Cl}_{2}$ (anhydrous, $15 \mathrm{~mL}$ ) and $4 \AA$ molecular sieves $(4 \mathrm{~g})$ at ambient temperature was reacted for $24 \mathrm{~h}$. No further purification was needed and $\mathbf{6 6}(585 \mathrm{mg}, 2.6 \mathrm{mmol}, 88 \%)$ was obtained as a red solid: $\mathrm{mp} 99-100^{\circ} \mathrm{C} ;{ }^{1} \mathrm{H}$ NMR $\delta 9.60(\mathrm{br} \mathrm{s}, 1 \mathrm{H}), 8.13(\mathrm{~d}, J=9.2 \mathrm{~Hz}, 1 \mathrm{H}), 7.02(\mathrm{~d}, J=2.2$ $\mathrm{Hz}, 1 \mathrm{H}), 6.66(\mathrm{dd}, J=9.2$ and $2.2 \mathrm{~Hz}, 1 \mathrm{H}), 6.19(\mathrm{~d}, J=9.4 \mathrm{~Hz}, 1 \mathrm{H}), 1.83(\mathrm{~s}, 3 \mathrm{H}), 1.79(\mathrm{~s}, 3$ $\mathrm{H}) ;{ }^{13} \mathrm{C}$ NMR $\delta 142.8(+), 141.8(+), 130.3(+), 128.2(-), 120.5(+), 117.8(-), 116.9(-), 113.8$ (-), 22.5 (-), 16.8 (-); IR (neat) 3326, 3112, 2927, 1570, 1494, 1410, 1190, $1064 \mathrm{~cm}^{-1}$; HRMS (EI) calc. for $\mathrm{C}_{10} \mathrm{H}_{11} \mathrm{ClN}_{2} \mathrm{O}_{2} 226.0509$, found 226.0500 .

\section{6-Methyl-2-nitro- $N$-[(2-methyl)-1-propenyl]benzenamine (68).}

To a solution of 2-methyl-6-nitroaminobenzene (67) (1.03 g, $6.8 \mathrm{mmol})$ and 2methylpropanal (55) (2.0 mL, $22.0 \mathrm{mmol})$ dissolved in 1,2-dichloroethane $(20 \mathrm{~mL})$ in a threaded pressure tube was added $4 \AA$ molecular sieves until the level of the sieves was just below that of the solvent (the molecular sieves were charged by heating to $120^{\circ} \mathrm{C}$ under vacuum overnight and then stored under argon atmosphere). The pressure tube was capped tightly with a threaded Teflon plug. The reaction was heated in a standard microwave oven for 30 seconds then allowed to cool for 3-5 minutes. This was repeated until the total heating time reached 15 minutes. The molecular sieves were removed by filtration and washed with $\mathrm{CH}_{2} \mathrm{Cl}_{2}$. The filtrate was 
concentrated and the product was purified by flash chromatography (hexanes/EtOAc, 9:1) to give $68(71 \mathrm{mg}, 0.34 \mathrm{mmol}, 5 \%)$ as a red paste: ${ }^{1} \mathrm{H}$ NMR $\delta 8.75(\mathrm{~d}, J=5.9 \mathrm{~Hz}, 1 \mathrm{H}), 7.95(\mathrm{~d}, J=$ $8.6 \mathrm{~Hz}, 1 \mathrm{H}), 7.30(\mathrm{~d}, J=7.4 \mathrm{~Hz}, 1 \mathrm{H}), 6.76(\mathrm{t}, J=7.7 \mathrm{~Hz}, 1 \mathrm{H}), 5.98(\mathrm{~d}, J=8.4 \mathrm{~Hz}, 1 \mathrm{H}), 2.40$ (s, $3 \mathrm{H}), 1.76$ (s, $3 \mathrm{H}), 1.72(\mathrm{~s}, 3 \mathrm{H}) ;{ }^{13} \mathrm{C}$ NMR $\delta 141.5(+), 138.2(-), 137.3(+), 129.4(+), 124.2$ $(-), 124.1(-), 118.5(-), 114.6(+), 22.2(-), 20.9(-), 16.3(-)$; IR (neat) 1634, 1519, $1339 \mathrm{~cm}^{-1}$.

\section{2,4-Dinitro- $N$-[(2-methyl)-1-propenyl]benzenamine (70).}

The same procedure as described for $\mathbf{6 8}$ was repeated except that a mixture of 2,4dinitroaminobenzene (69) (1.00 g, $5.5 \mathrm{mmol}), 2$-methylpropanal (55) (1.0 mL, $13.9 \mathrm{mmol})$ and 1,2-dichloroethane $(20 \mathrm{~mL})$ was reacted for a total of 15 minutes. Purification by flash chromatography (hexanes/EtOAc, 9:1) gave 70 (1.00 g, $4.3 \mathrm{mmol}, 78 \%)$ as a red solid: $\mathrm{mp} 113$ $115^{\circ} \mathrm{C} ;{ }^{1} \mathrm{H}$ NMR $\delta 10.06(\mathrm{~d}, J=8.2 \mathrm{~Hz}, 1 \mathrm{H}), 9.16(\mathrm{~d}, J=2.5 \mathrm{~Hz}, 1 \mathrm{H}), 8.27(\mathrm{dd}, J=9.6$ and 2.7 $\mathrm{Hz}, 1 \mathrm{H}), 7.12(\mathrm{~d}, J=9.6 \mathrm{~Hz}, 1 \mathrm{H}), 6.32(\mathrm{~d}, J=9.4 \mathrm{~Hz}, 1 \mathrm{H}), 1.88(\mathrm{~s}, 3 \mathrm{H}), 1.85(\mathrm{~s}, 3 \mathrm{H}) ;{ }^{13} \mathrm{C}$ NMR $\delta 143.8(+), 136.5(+), 130.0(-), 129.9(+), 124.1(-), 124.0(+), 117.0(-), 114.4(-), 22.5$ (-), 16.8 (-); IR (neat) 1590, 1461, 1426, 1330, $1307 \mathrm{~cm}^{-1}$; Anal. calcd for $\mathrm{C}_{10} \mathrm{H}_{11} \mathrm{~N}_{3} \mathrm{O}_{4}$ : C, 50.63; H, 4.67, found: C, 50.79; H, 4.77.

\section{3-Methyl-2-nitroaminobenzene ${ }^{64}$ (71).}

To a solution of 3-methyl-2-nitrobenzoic acid (84) (4.90 g, $27.0 \mathrm{mmol})$ dissolved in 1,2dichloroethane $(100 \mathrm{~mL})$ was added $\mathrm{SOCl}_{2}(10.0 \mathrm{~mL}, 137 \mathrm{mmol})$ and $N, N$-dimethylformamide (DMF) (1 drop). The reaction refluxed under argon atmosphere for $3 \mathrm{~h}$ and was then concentrated by vacuum distillation. The resulting material was added to acetone $\left(75 \mathrm{~mL}, 0{ }^{\circ} \mathrm{C}\right)$. To this solution was added $\mathrm{NaN}_{3}\left(10.1 \mathrm{~g}, 155 \mathrm{mmol}\right.$ in $\left.40 \mathrm{~mL} \mathrm{H}_{2} \mathrm{O}\right)$ and the mixture stirred for 
10 minutes. This solution was added to $\mathrm{H}_{2} \mathrm{O}(300 \mathrm{~mL})$ and the resulting solid (acyl azide) was collected by filtration and used without further purification.

The crude acyl azide was dissolved in $\mathrm{AcOH} /$ distilled $\mathrm{H}_{2} \mathrm{O}(10: 1,330 \mathrm{~mL})$ and refluxed for $2 \mathrm{~h}$. The reaction was concentrated by vacuum distillation. The resulting solid was recrystallized from AcOH to give 71 (2.48 g, $16.3 \mathrm{mmol}, 60 \%)$ : ${ }^{1} \mathrm{H}$ NMR $\delta 7.14$ (t, $J=7.7 \mathrm{~Hz}, 1$ H), $6.65(\mathrm{~d}, J=8.3 \mathrm{~Hz}, 1 \mathrm{H}), 6.58(\mathrm{~d}, J=7.3 \mathrm{~Hz}, 1 \mathrm{H}), 5.15(\mathrm{br} \mathrm{s}, 2 \mathrm{H}), 2.47(\mathrm{~s}, 3 \mathrm{H}) ;{ }^{13} \mathrm{C} \mathrm{NMR}$ $(150 \mathrm{MHz}) \delta 142.9(+), 136.1(+), 135.0(+), 132.7(-), 120.7(-), 116.0(-), 20.9(-)$.

\section{3-Methyl-2-nitro- $N$-[(2-methyl)-1-propenyl]benzenamine (72).}

The same procedure as described for $\mathbf{5 6}$ was repeated except that a mixture of 3-methyl2-nitroaminobenzene (71) (500 mg, $3.3 \mathrm{mmol})$, 2-methylpropanal (55) (0.50 mL, $5.5 \mathrm{mmol})$, benzene (anhydrous, $20 \mathrm{~mL}$ ) and $4 \AA$ molecular sieves (15 g) at ambient temperature was reacted for 3 days. Purification by flash chromatography (hexanes) gave 72 (241 mg, $1.17 \mathrm{mmol}, 36 \%$ ) as a red paste: ${ }^{1} \mathrm{H}$ NMR $\delta 8.24(\mathrm{~d}, J=8.4 \mathrm{~Hz}, 1 \mathrm{H}), 7.23(\mathrm{t}, J=7.9 \mathrm{~Hz}, 1 \mathrm{H}), 6.84(\mathrm{~d}, J=8.6 \mathrm{~Hz}$, $1 \mathrm{H}), 6.58$ (d, $J=7.4 \mathrm{~Hz}, 1 \mathrm{H}), 6.12(\mathrm{~d}, J=9.4 \mathrm{~Hz}, 1 \mathrm{H}), 2.49$ (s, $3 \mathrm{H}), 1.78(\mathrm{~s}, 3 \mathrm{H}), 1.73$ (s, 3 H); ${ }^{13} \mathrm{C}$ NMR $\delta 140.3(+), 135.9(+), 135.5,133.3(-), 120.5(-), 119.4(-), 116.8(+), 112.3(-)$, $22.5(-), 21.6(-), 16.6(-)$.

\section{[4-(2-Methylpropenylamino)-3-nitrophenyl]phenylmethanone (74).}

The same procedure as described for $\mathbf{5 6}$ was repeated except that a mixture of 3-nitro-4aminobenzophenone (73) (500 mg, $2.1 \mathrm{mmol}), 2$-methylpropanal (55) (0.30 mL, $3.3 \mathrm{mmol})$, $\mathrm{CH}_{2} \mathrm{Cl}_{2}$ (anhydrous, $40 \mathrm{~mL}$ ) and $4 \AA$ molecular sieves $(15 \mathrm{~g}$ ) at ambient temperature was reacted for 12 days. Purification by flash chromatography (hexanes/EtOAc, 9:1) gave 74 (120 mg, 0.41 
mmol, 20\%) as a red solid: ${ }^{1} \mathrm{H}$ NMR $\delta 9.96(\mathrm{~d}, J=9.4 \mathrm{~Hz}, 1 \mathrm{H}), 8.66(\mathrm{~d}, J=2.0 \mathrm{~Hz}, 1 \mathrm{H}), 8.04$ (dd, $J=9.1$ and $2.0 \mathrm{~Hz}, 1 \mathrm{H}), 7.75(\mathrm{dd}, J=8.4$ and $1.5 \mathrm{~Hz}, 2 \mathrm{H}), 7.60(\mathrm{t}, 1 \mathrm{H}), 7.50(\mathrm{t}, 2 \mathrm{H}), 7.14$ $(\mathrm{d}, J=9.1 \mathrm{~Hz}, 1 \mathrm{H}), 6.34(\mathrm{~d}, J=9.4 \mathrm{~Hz}, 1 \mathrm{H}), 1.86(\mathrm{~s}, 3 \mathrm{H}), 1.84(\mathrm{~s}, 3 \mathrm{H}) ;{ }^{13} \mathrm{C} \mathrm{NMR} \delta 193.4(+)$, $143.4(+), 137.4(+), 136.8(-), 132.3(-), 130.7(-), 130.5(+), 129.4(-), 128.5(-), 125.5(+)$, $121.8(+), 117.6(-), 114.3(-), 22.6(-), 16.9(-)$; IR (neat) 1650, 1612, 1209, $1132 \mathrm{~cm}^{-1}$.

\section{Methyl 4-amino-3-nitrobenzoate ${ }^{65}$ (75).}

Methanol (30.0 mL, $741 \mathrm{mmol})$, 4-amino-3-nitrobenzoic acid (85) (2.00 g, $11.0 \mathrm{mmol})$, $\mathrm{H}_{2} \mathrm{SO}_{4}$ (concentrated, $1.0 \mathrm{~mL}$ ) and benzene (anhydrous, $100 \mathrm{~mL}$ ) were combined in a roundbottomed flask fitted with a Dean-Stark trap and a reflux condenser. The reaction was heated and stirred at reflux for $13 \mathrm{~h}$. The reaction mixture was then concentrated and added to $\mathrm{CHCl}_{3}$ (100 mL). The solution was washed with $\mathrm{NaHCO}_{3}(20 \%$ aqueous solution, $2 \mathrm{X} 100 \mathrm{~mL})$. The organic phase was dried $\left(\mathrm{MgSO}_{4}\right)$, filtered and concentrated. Purification by flash chromatography (hexanes/EtOAc, 9:1, 8:2 and 7:3) gave 75 (1.50 g, $7.6 \mathrm{mmol}, 69 \%)$ as a yellow solid.

\section{Methyl 4-(2-methylpropenylamino)-3-nitrobenzoate (76).}

The same procedure as described for 56 was repeated except that a mixture of methyl 4amino-3-nitrobenzoate (75) (500 mg, $2.6 \mathrm{mmol}$ ), 2-methylpropanal (55) (5.0 mL, $55.1 \mathrm{mmol})$, camphor sulfonic acid (10 mg), $\mathrm{CH}_{2} \mathrm{Cl}_{2}$ (anhydrous, $150 \mathrm{~mL}$ ) and $4 \AA$ molecular sieves $(50 \mathrm{~g})$ at ambient temperature was reacted for 11 days. Purification by flash chromatography (hexanes/EtOAc, 95:5) gave 76 (470 mg, $1.88 \mathrm{mmol}, 74 \%$ ) as a red solid: $\mathrm{mp} 121-124{ }^{\circ} \mathrm{C} ;{ }^{1} \mathrm{H}$ NMR $\delta 9.87(\mathrm{~d}, J=11.4 \mathrm{~Hz}, 1 \mathrm{H}), 8.89(\mathrm{~d}, J=2.0 \mathrm{~Hz}, 1 \mathrm{H}), 8.05(\mathrm{dd}, J=9.2$ and $1.5 \mathrm{~Hz}, 1 \mathrm{H})$, 
$7.06(\mathrm{~d}, J=9.2 \mathrm{~Hz}, 1 \mathrm{H}), 6.30(\mathrm{~d}, J=9.4 \mathrm{~Hz}, 1 \mathrm{H}), 3.91(\mathrm{~s}, 3 \mathrm{H}), 1.85(\mathrm{~s}, 3 \mathrm{H}), 1.82(\mathrm{~s}, 3 \mathrm{H}) ;{ }^{13} \mathrm{C}$ NMR $\delta 165.4(+), 143.4(+), 136.1(-), 131.0(+), 129.4(-), 121.2(+), 118.1(+), 117.6(-), 113.9$ (-), 52.1 (-), $22.6(-), 16.8(-)$; IR (neat) 1707, 1615, 1523, 1437, 1287, $1217 \mathrm{~cm}^{-1}$.

\section{4-Methoxy-2-nitro- $N$-(cyclohexylmethylene)benzenamine (78).}

The same procedure as described for $\mathbf{5 6}$ was repeated except that a mixture of 4methoxy-2-nitroaminobenzene (61) (508 mg, $3.0 \mathrm{mmol})$, formylcyclohexane (77) $(0.360 \mathrm{~mL}, 3.2$ mmol), benzene (anhydrous, $10 \mathrm{~mL}$ ) and $4 \AA$ molecular sieves ( $4 \mathrm{~g}$ ) at ambient temperature was reacted for $2.5 \mathrm{~h}$. No further purification was needed and 78 (696 mg, $2.7 \mathrm{mmol}, 88 \%)$ was obtained as a red solid: $\mathrm{mp} 46-48^{\circ} \mathrm{C} ;{ }^{1} \mathrm{H}$ NMR $\delta 9.68(\mathrm{br} \mathrm{s}, 1 \mathrm{H}), 7.60(\mathrm{~d}, J=2.7 \mathrm{~Hz}, 1 \mathrm{H}), 7.15$ (dd, $J=9.4$ and $3.2 \mathrm{~Hz}, 1 \mathrm{H}), 7.05(\mathrm{~d}, J=9.2 \mathrm{~Hz}, 1 \mathrm{H}), 6.22(\mathrm{~d}, J=9.4 \mathrm{~Hz}, 1 \mathrm{H}), 3.81(\mathrm{~s}, 3 \mathrm{H})$, 2.30-1.50 (m, $10 \mathrm{H}) ;{ }^{13} \mathrm{C}$ NMR $\delta 150.3(+), 137.4(+), 130.6(+), 127.2(-), 126.1(+), 115.6(-)$, $115.5(-), 106.6(-), 55.7(-), 33.6(+), 28.3(+), 27.5(+), 26.9(+), 26.6(+)$; IR (neat) 2929, $2360,1572,1517,1411,1283,1214 \mathrm{~cm}^{-1}$; HRMS (EI) calc. for $\mathrm{C}_{14} \mathrm{H}_{18} \mathrm{~N}_{2} \mathrm{O}_{3} 262.1317$, found 262.1310.

\section{4-Methoxy-2-nitro- $N$-(2,2-diphenylethenyl)benzenamine (80).}

The same procedure as described for $\mathbf{5 6}$ was repeated except that a mixture of 4methoxy-2-nitroaminobenzene (61) (304 mg, $1.8 \mathrm{mmol})$, diphenylacetaldehyde (79) $(0.40 \mathrm{~mL}$, $2.3 \mathrm{mmol}$ ), $\mathrm{CH}_{2} \mathrm{Cl}_{2}$ (anhydrous, $30 \mathrm{~mL}$ ) and $4 \AA$ molecular sieves $(15 \mathrm{~g}$ ) at ambient temperature was reacted for 3 days. Purification by flash chromatography (hexanes/EtOAc, 9:1) gave $\mathbf{8 0}$ (572 mg, $1.7 \mathrm{mmol}, 91 \%$ ) as a red solid: $\mathrm{mp} 152-153^{\circ} \mathrm{C} ;{ }^{1} \mathrm{H}$ NMR $\delta 9.93(\mathrm{~d}, J=11.6 \mathrm{~Hz}, 1 \mathrm{H})$, $7.53(\mathrm{~d}, J=2.7 \mathrm{~Hz}, 1 \mathrm{H}), 7.48-7.05(\mathrm{~m}, 13 \mathrm{H}), 3.74(\mathrm{~s}, 3 \mathrm{H}) ;{ }^{13} \mathrm{C} \mathrm{NMR} \delta 151.3(+), 140.7(+)$, 
$137.4(+), 135.1(+), 132.2(+), 129.7(-), 129.3(-), 128.4(-), 127.9(-), 126.6(-), 126.5$ (two overlapping peaks; both -), 124.0 (+), $121.6(-), 115.8$ (-), 107.4 (-), 55.8 (-); IR (neat) 3055, $1517,1283,1218,1139,1062 \mathrm{~cm}^{-1}$; HRMS (EI) calc. for $\mathrm{C}_{21} \mathrm{H}_{18} \mathrm{~N}_{2} \mathrm{O}_{3} 346.1317$, found 346.1306.

(E)-4-Chloro-2-nitro- $N$-(2-phenylethylene)benzenamine (82-E) and (Z)-4-chloro-2-nitro- $\mathrm{N}$ (2-phenylethylene)benzenamine (82-Z).

The same procedure as described for $\mathbf{5 6}$ was repeated except that a mixture of 4-chloro-2nitroaminobenzene (63) (1.00 g, $5.8 \mathrm{mmol})$, phenylacetaldehyde (81) $(0.70 \mathrm{~mL}, 6.0 \mathrm{mmol})$, $\mathrm{CH}_{2} \mathrm{Cl}_{2}$ (anhydrous, $35 \mathrm{~mL}$ ) and $4 \AA$ molecular sieves $(15 \mathrm{~g})$ at ambient temperature was reacted for $20 \mathrm{~h}$. A virtually inseparable mixture of 82- $\boldsymbol{E}$ and $\mathbf{8 2 - Z}(1.35 \mathrm{~g}, 4.9 \mathrm{mmol}, 85 \%)$ resulted as a red solid: 82-Z mp 104-106 ${ }^{\circ} \mathrm{C} ;{ }^{1} \mathrm{H}$ NMR $\delta 10.41(\mathrm{~d}, J=10.6 \mathrm{~Hz}, 1 \mathrm{H}), 8.20(\mathrm{~d}, J=2.5 \mathrm{~Hz}, 1$ H), 7.50-7.40 (m, $5 \mathrm{H}), 7.27(\mathrm{tt}, J=6.9$ and $1.7 \mathrm{~Hz}, 1 \mathrm{H}), 7.18(\mathrm{~d}, J=9.2 \mathrm{~Hz}, 1 \mathrm{H}), 6.64(\mathrm{dd}, J=$ 11.1 and $9.4 \mathrm{~Hz}, 1 \mathrm{H}), 5.83(\mathrm{~d}, J=9.2 \mathrm{~Hz}, 1 \mathrm{H}) ;{ }^{13} \mathrm{C} \mathrm{NMR} \delta 138.9(+), 136.3(-), 135.2(+)$, $132.7(+), 129.1(-), 127.7(-), 127.1(-), 126.1(-), 122.9(+), 122.5(-) 115.8(-), 111.5(-)$; IR (neat) $3317,2352,1640,1619,1567,1513,1341 \mathrm{~cm}^{-1}$; HRMS (EI) calc. for $\mathrm{C}_{14} \mathrm{H}_{11} \mathrm{ClN}_{2} \mathrm{O}_{2}$ 274.0509, found 274.0513; 82-E ${ }^{1} \mathrm{H}$ NMR $\delta 9.87$ (d, $\left.J=11.9 \mathrm{~Hz}, 1 \mathrm{H}\right), 8.14(\mathrm{~d}, J=2.5 \mathrm{~Hz}, 1$ H), 7.60-7.20 (m, 6 H), $7.06(\mathrm{~d}, J=15.8 \mathrm{~Hz}, 1 \mathrm{H}), 6.98(\mathrm{~d}, J=11.4 \mathrm{~Hz}, 1 \mathrm{H}), 6.16(\mathrm{~d}, J=15.6$ $\mathrm{Hz}, 1 \mathrm{H})$. 
3-Nitro- $N$-[(2-methyl)-1-propenyl]-2-pyridinamine (87) and $N$-(1-(3-nitropyridin-2ylamino)-2-methylpropyl)-3-nitropyridin-2-amine (88).

The same procedure as described for $\mathbf{5 6}$ was repeated except that a mixture of 2-amino-3nitropyridine (86) (505 mg, $3.6 \mathrm{mmol}$ ), 2-methylpropanal (55) (0.35 mL, $3.9 \mathrm{mmol}), \mathrm{CH}_{2} \mathrm{Cl}_{2}$ (anhydrous, $35 \mathrm{~mL}$ ) and $4 \AA$ molecular sieves $(15 \mathrm{~g}$ ) at ambient temperature was reacted for 5 days. Purification by flash chromatography (hexanes/EtOAc, 9:1) gave 87 (139 mg, $0.7 \mathrm{mmol}$, $20 \%)$ as a red solid and $\mathbf{8 8}(258 \mathrm{mg}, 0.8 \mathrm{mmol}, 44 \%)$ as a yellow solid: $87 \mathrm{mp} 62-64{ }^{\circ} \mathrm{C} ;{ }^{1} \mathrm{H}$ NMR $\delta 9.87$ (br s, 1 H), 8.50-8.40 (m, 2 H), 7.08 (d, $J=8.2 \mathrm{~Hz}, 1 \mathrm{H}), 6.80-6.60(\mathrm{~m}, 1 \mathrm{H}), 1.84$ (s, $3 \mathrm{H}), 1.82(\mathrm{~s}, 3 \mathrm{H}) ;{ }^{13} \mathrm{C}$ NMR $\delta 155.8(-), 148.4(+), 135.4(-), 127.6(+), 117.3(-), 116.8(+)$, $112.8(-), 22.7$ (-), 16.8 (-); IR (neat) 3364, 2917, 1678, 1604, 1574, 1494, $1444 \mathrm{~cm}^{-1}$; Anal. calcd for $\mathrm{C}_{9} \mathrm{H}_{11} \mathrm{~N}_{3} \mathrm{O}_{2}$ : C, 55.95; $\mathrm{H}, 5.74$, found: $\mathrm{C}, 56.06 ; \mathrm{H}, 5.69 ; 88 \mathrm{mp} 101-103{ }^{\circ} \mathrm{C} ;{ }^{1} \mathrm{H}$ NMR $\delta 8.81(\mathrm{~d}, J=7.9 \mathrm{~Hz}, 2 \mathrm{H}), 8.45-8.35(\mathrm{~m}, 4 \mathrm{H}), 6.73-6.67$ (m, $2 \mathrm{H}), 6.29$ (quartet, $J=7.6 \mathrm{~Hz}, 1$ H), $2.63($ octet, $J=6.9 \mathrm{~Hz}, 1 \mathrm{H}), 1.11(\mathrm{~d}, J=6.7 \mathrm{~Hz}, 6 \mathrm{H}) ;{ }^{13} \mathrm{C}$ NMR $\delta 155.2(-), 151.7(+)$, $135.1(-), 128.1(+), 112.4(-), 64.2(-), 32.0(-), 18.4$ (-); IR (neat) 3372, 1600, 1569, 1481, $1443,1245 \mathrm{~cm}^{-1}$.

\section{2-(2-Nitrophenylamino)-2-cyclohexen-1-one (90).}

2-Nitroaminobenzene (52) (2.00 g, 14.5 mmol), 1,2-cyclohexanedione (89) (1.90 g, 16.9 mmol), benzene (anhydrous, $40 \mathrm{~mL}$ ) and concentrated $\mathrm{H}_{2} \mathrm{SO}_{4}$ (5 drops) were combined in a round-bottomed flask fitted with a Dean-Stark trap and a reflux condenser. The reaction was heated and stirred at reflux for $21 \mathrm{~h}$. The reaction mixture was then concentrated. Purification by flash chromatography (hexanes/EtOAc, 9:1, then 8:2) gave $90(1.07 \mathrm{~g}, 4.6 \mathrm{mmol}, 32 \%)$ as an orange solid: $\mathrm{mp} 75-77^{\circ} \mathrm{C} ;{ }^{1} \mathrm{H}$ NMR $\delta 9.38(\mathrm{br} \mathrm{s}, 1 \mathrm{H}), 8.18(\mathrm{dd}, J=8.7$ and $1.5 \mathrm{~Hz}, 1 \mathrm{H}), 7.43$ 
(ddd, $J=8.7,7.4$ and $1.7 \mathrm{~Hz}, 1 \mathrm{H}), 7.31(\mathrm{dd}, J=8.7$ and $1.5 \mathrm{~Hz}, 1 \mathrm{H}), 6.87-6.77(\mathrm{~m}, 2 \mathrm{H}), 2.65-$

$2.54(\mathrm{~m}, 4 \mathrm{H}), 2.10$ (pentet, $J=6.2 \mathrm{~Hz}, 2 \mathrm{H}) ;{ }^{13} \mathrm{C}$ NMR $\delta 194.6(+), 140.6(+), 135.2(-), 134.8$

$(+), 134.6(+), 129.7(-), 126.7(-), 118.1(-), 116.8(-), 37.7(+), 25.0(+), 22.4(+)$; IR (neat) $3294,2944,1672,1571,1430,1246,1155 \mathrm{~cm}^{-1}$.

3-(2-Nitrophenylamino)-2-cyclohexen-1-one ${ }^{66}(92)$.

The same procedure as described for $\mathbf{9 0}$ was repeated except that a mixture of 2nitroaminobenzene (52) (1.26 g, 9.1 mmol), 1,3-cyclohexanedione (91) (1.00 g, 8.9 mmol), benzene (anhydrous, $30 \mathrm{~mL}$ ) and concentrated $\mathrm{H}_{2} \mathrm{SO}_{4}(3$ drops) was reacted for $22 \mathrm{~h}$. The product was recrystallized from EtOAc to give $92(1.45 \mathrm{~g}, 6.3 \mathrm{mmol}, 70 \%)$ as a yellow solid: ${ }^{1} \mathrm{H}$ NMR (600 MHz) $\delta 8.66($ br s, $1 \mathrm{H}), 8.17(\mathrm{dd}, J=8.4$ and $1.8 \mathrm{~Hz}, 1 \mathrm{H}), 7.68(\mathrm{dd}, J=7.8$ and 1.2 $\mathrm{Hz}, 1 \mathrm{H}), 7.58(\mathrm{dt}, J=7.2$ and $1.8 \mathrm{~Hz}, 1 \mathrm{H}), 7.15(\mathrm{dt}, J=7.2$ and $1.2 \mathrm{~Hz}, 1 \mathrm{H}), 5.97(\mathrm{~s}, 1 \mathrm{H}), 2.60$ (t, $J=6.0 \mathrm{~Hz}, 2 \mathrm{H}), 2.43(\mathrm{t}, J=6.0 \mathrm{~Hz}, 2 \mathrm{H}), 2.10$ (pentet, $J=6.6 \mathrm{~Hz}, 2 \mathrm{H}) ;{ }^{13} \mathrm{C}$ NMR $(150$ MHz) $\delta$ 198.7, 158.0, 138.7, 135.7, 135.0, 126.4, 123.4, 123.1, 105.0, 36.6, 30.6, 21.5.

\section{(Z)-4-(2-Nitrophenylamino)-3-buten-2-one ${ }^{67}$ (95).}

2-Nitroaminobenzene (52) (1.50 g, 10.9 mmol), (E)-4-methoxy-3-buten-2-one ${ }^{26}(\mathbf{9 4})(1.0$ $\mathrm{mL}, 9.8 \mathrm{mmol}$ ), $p$-toluenesulfonic acid $\left(10 \mathrm{mg}\right.$ ) and $\mathrm{CH}_{2} \mathrm{Cl}_{2}$ (anhydrous, $10 \mathrm{~mL}$ ) were combined, heated and stirred at reflux for $9 \mathrm{~h}$. The reaction mixture was then concentrated. Purification by flash chromatography (hexanes/EtOAc, 9:1) gave 95 (1.98 g, $9.6 \mathrm{mmol}, 98 \%)$ as a yellow solid: ${ }^{1} \mathrm{H}$ NMR $\delta 13.11$ (br s, $1 \mathrm{H}$ ), 8.24 (dd, $J=8.4$ and $\left.1.5 \mathrm{~Hz}, 1 \mathrm{H}\right), 7.59$ (t, $\left.J=7.2 \mathrm{~Hz}, 1 \mathrm{H}\right), 7.36$ (d, $J=8.7 \mathrm{~Hz}, 1 \mathrm{H}), 7.24(\mathrm{dd}, J=11.8$ and $8.1 \mathrm{~Hz}, 1 \mathrm{H}), 7.08(\mathrm{t}, J=8.4 \mathrm{~Hz}, 1 \mathrm{H}), 5.55(\mathrm{~d}, J=8.1$ 
$\mathrm{Hz}, 1 \mathrm{H}), 2.24$ (s, $3 \mathrm{H}) ;{ }^{13} \mathrm{C}$ NMR (150 MHz) $\delta$ 199.0, 138.6, 137.4, 136.0, 135.5, 126.8, 121.5, $115.4,102.4,30.0$.

\section{(Z)-4-(4-Methyl-2-nitrophenylamino)-3-buten-2-one (96).}

The same procedure as described for $\mathbf{9 5}$ was repeated except that a mixture of 4-methyl2-nitroaminobenzene (59) (2.00 g, $13.1 \mathrm{mmol}),(E)-4$-methoxy-3-buten-2-one ${ }^{26}(\mathbf{9 4})(1.4 \mathrm{~mL}$, $13.7 \mathrm{mmol}$ ), $p$-toluenesulfonic acid $\left(10 \mathrm{mg}\right.$ ) and $\mathrm{CH}_{2} \mathrm{Cl}_{2}$ (anhydrous, $15 \mathrm{~mL}$ ) reacted at reflux for $7 \mathrm{~h}$. The product was recrystallized from ethanol to give $96(2.48 \mathrm{~g}, 11.2 \mathrm{mmol}, 86 \%)$ as a yellow solid: $\mathrm{mp} 135-137{ }^{\circ} \mathrm{C} ;{ }^{1} \mathrm{H}$ NMR $\delta 13.00(\mathrm{br} \mathrm{s}, 1 \mathrm{H}), 8.04(\mathrm{~s}, 1 \mathrm{H}), 7.41(\mathrm{~d}, J=8.6 \mathrm{~Hz}, 1$ H), 7.25-7.15 (m, $2 \mathrm{H}), 5.52(\mathrm{~d}, J=7.9 \mathrm{~Hz}, 1 \mathrm{H}), 2.37$ (s, $3 \mathrm{H}), 2.23(\mathrm{~s}, 3 \mathrm{H}) ;{ }^{13} \mathrm{C}$ NMR $\delta 198.8$ (+), $139.1(-), 136.5(-), 135.7(+), 135.1(+), 131.8(+), 126.3(-), 115.4(-), 101.7(-), 29.9(-)$, 20.2 (-); IR (neat) 1646, 1564, 1528, 1460, 1345, 1269, $1196 \mathrm{~cm}^{-1}$.

\section{(Z)-4-(5-Methyl-2-nitrophenylamino)-3-buten-2-one (97).}

The same procedure as described for $\mathbf{9 5}$ was repeated except that a mixture of 5-methyl2-nitroaminobenzene (93) (2.00 g, $13.1 \mathrm{mmol}),(E)-4-m e t h o x y-3-b u t e n-2-o n e^{26}(\mathbf{9 4})(1.4 \mathrm{~mL}$, $13.7 \mathrm{mmol}$ ), $p$-toluenesulfonic acid $\left(10 \mathrm{mg}\right.$ ) and $\mathrm{CH}_{2} \mathrm{Cl}_{2}$ (anhydrous, $15 \mathrm{~mL}$ ) reacted at reflux for $12 \mathrm{~h}$. The product was recrystallized from ethanol to give $\mathbf{9 7}(2.07 \mathrm{~g}, 9.4 \mathrm{mmol}, 71 \%)$ as an orange solid: $\mathrm{mp} 124-126{ }^{\circ} \mathrm{C} ;{ }^{1} \mathrm{H}$ NMR $\delta 13.10(\mathrm{~d}, J=9.9 \mathrm{~Hz}, 1 \mathrm{H}), 8.14(\mathrm{~d}, J=8.6 \mathrm{~Hz}, 1 \mathrm{H})$, 7.25 (dd, $J=11.9$ and $8.3 \mathrm{~Hz}, 1 \mathrm{H}), 7.14(\mathrm{~s}, 1 \mathrm{H}), 6.87(\mathrm{~d}, J=8.6 \mathrm{~Hz}, 1 \mathrm{H}), 5.54(\mathrm{~d}, J=7.9 \mathrm{~Hz}, 1$ H), 2.43 (s, $3 \mathrm{H}), 2.24$ (s, $3 \mathrm{H}) ;{ }^{13} \mathrm{C}$ NMR (150 MHz) $\delta 198.8(+), 147.2(+), 138.6(-), 137.2(+)$, $133.7(+), 126.6(-), 122.6(-), 115.3(-), 102.1(-), 29.9(-), 21.9(-)$; IR (neat) 1654, 1595, 1500, $1334,1195,1168 \mathrm{~cm}^{-1}$. 


\section{1,2-Dihydro-2,2,7-trimethylquinoxaline (98) and 3,4-dihydro-3,3,6-trimethyl-2- quinoxalinone $^{63}(99)$.}

The same procedure as described for 57 was repeated except that a mixture of 4-methyl2-nitro- $N$-[(2-methyl)-1-propenyl]benzenamine (60) (102 mg, $0.49 \mathrm{mmol}), \mathrm{Pd}(\mathrm{dba})_{2}(18 \mathrm{mg}$, $0.031 \mathrm{mmol})$, dppp (14 mg, $0.034 \mathrm{mmol}), 1,10$-phenanthroline monohydrate (phen) (12 mg, $0.067 \mathrm{mmol})$ and DMF $(5 \mathrm{~mL})$ was reacted at $70{ }^{\circ} \mathrm{C}$ under $\mathrm{CO}(6 \mathrm{~atm})$ for $2 \mathrm{~h}$. The reaction mixture was diluted with $\mathrm{CH}_{2} \mathrm{Cl}_{2}(40 \mathrm{~mL})$ and washed with brine $(3 \mathrm{X} 30 \mathrm{~mL})$. The combined aqueous phases were extracted with $\mathrm{CH}_{2} \mathrm{Cl}_{2}(1 \mathrm{X} 30 \mathrm{~mL})$. The combined organic phases were dried $\left(\mathrm{MgSO}_{4}\right)$, filtered and concentrated. Purification by flash chromatography (hexanes/EtOAc, 7:3) gave 98 (43 mg, $0.25 \mathrm{mmol}, 50 \%)$ and 99 (42 $\mathrm{mg}, 0.22 \mathrm{mmol}, 45 \%)$ as off-white solids: $98 \mathrm{mp} 112-115^{\circ} \mathrm{C} ;{ }^{1} \mathrm{H}$ NMR $\delta 7.23(\mathrm{~s}, 1 \mathrm{H}), 7.13(\mathrm{~d}, J=7.7 \mathrm{~Hz}, 1 \mathrm{H}), 6.53(\mathrm{~d}$, $J=7.7 \mathrm{~Hz}, 1 \mathrm{H}), 6.31(\mathrm{~s}, 1 \mathrm{H}), 3.87(\mathrm{~d}, J=4.2 \mathrm{~Hz}, 1 \mathrm{H}), 2.42(\mathrm{~s}, 3 \mathrm{H}), 1.30(\mathrm{~s}, 6 \mathrm{H}) ;{ }^{13} \mathrm{C} \mathrm{NMR} \delta$ $159.5(-), 139.0(+), 136.4(+), 129.2(+), 127.4(-), 119.2(-), 114.1(-), 50.3(+), 27.1(-), 21.4$ (-); IR (neat) 3240, 2964, 1610, 1482, 1453, 1322, $1246 \mathrm{~cm}^{-1}$; HRMS (EI) calc. for $\mathrm{C}_{11} \mathrm{H}_{14} \mathrm{~N}_{2}$ 174.1157, found 174.1163; $99{ }^{1} \mathrm{H}$ NMR $\delta 8.46$ (br s, $\left.1 \mathrm{H}\right), 6.64(\mathrm{~d}, J=7.9 \mathrm{~Hz}, 1 \mathrm{H}), 6.57(\mathrm{~d}, J=$ $8.6 \mathrm{~Hz}, 1 \mathrm{H}), 6.49$ (s, $1 \mathrm{H}), 3.87$ (br s, $1 \mathrm{H}), 2.24$ (s, $3 \mathrm{H}), 1.40(\mathrm{~s}, 6 \mathrm{H}) ;{ }^{13} \mathrm{C} \mathrm{NMR}(150 \mathrm{MHz}) \delta$ $171.5,133.4,132.7,123.2,119.9,115.0,114.9,55.4,25.5,21.0$.

\section{1,2-Dihydro-2,2-dimethyl-7-methoxyquinoxaline (100) and 3,4-dihydro-3,3-dimethyl-6- methoxy-2-quinoxalinone $^{68}$ (101).}

The same procedure as described for 57 was repeated except that a mixture of 4methoxy-2-nitro- $N$-[(2-methyl)-1-propenyl]benzenamine (62) (200 mg, $0.90 \mathrm{mmol}), \operatorname{Pd}(\mathrm{dba})_{2}$ (31 mg, $0.05 \mathrm{mmol})$, dppp (22 mg, $0.05 \mathrm{mmol})$, phen (19 mg, $0.10 \mathrm{mmol}$ ) and DMF (3 mL) was 
reacted at $70{ }^{\circ} \mathrm{C}$ under $\mathrm{CO}(6 \mathrm{~atm})$ for $18 \mathrm{~h}$. The reaction mixture was diluted with $\mathrm{CH}_{2} \mathrm{Cl}_{2}(40$ $\mathrm{mL}$ ) and washed with brine ( $3 \mathrm{X} 40 \mathrm{~mL}$ ). The combined aqueous phases were extracted with $\mathrm{CH}_{2} \mathrm{Cl}_{2}(1 \mathrm{X} 40 \mathrm{~mL})$. The combined organic phases were dried $\left(\mathrm{MgSO}_{4}\right)$, filtered and concentrated. Purification by flash chromatography (hexanes/EtOAc, 8:2 and 6:4) gave 100 (130 $\mathrm{mg}, 0.68 \mathrm{mmol}, 76 \%)$ and $101(20 \mathrm{mg}, 0.10 \mathrm{mmol}, 11 \%)$ as off-white solids: $100 \mathrm{mp} 65-66^{\circ} \mathrm{C}$; ${ }^{1} \mathrm{H}$ NMR $\delta$ 7.20-7.10 (m, $\left.2 \mathrm{H}\right), 6.26(\mathrm{dd}, J=8.6$ and $2.5 \mathrm{~Hz}, 1 \mathrm{H}), 6.02(\mathrm{~d}, J=2.5 \mathrm{~Hz}, 1 \mathrm{H}), 3.85$ (s, $1 \mathrm{H}), 3.74(\mathrm{~s}, 3 \mathrm{H}), 1.30(\mathrm{~s}, 6 \mathrm{H}) ;{ }^{13} \mathrm{C}$ NMR $\delta 160.1(+), 157.7(-), 137.8(+), 128.6(-), 125.7$ (+), $103.4(-), 98.9(-), 55.2(-), 50.1(+), 27.1$ (-); IR (neat) 3362, 3260, 2963, 1619, 1583, 1454, 1249, 1209, 1166, $1035 \mathrm{~cm}^{-1}$; HRMS (EI) calc. for $\mathrm{C}_{11} \mathrm{H}_{14} \mathrm{~N}_{2} \mathrm{O}$ 190.1106, found 190.1103; 101 ${ }^{1} \mathrm{H}$ NMR $\delta 7.81(\mathrm{br} \mathrm{s}, 1 \mathrm{H}), 6.62(\mathrm{~d}, J=8.4 \mathrm{~Hz}, 1 \mathrm{H}), 6.32(\mathrm{dd}, J=8.4$ and $2.5 \mathrm{~Hz}, 1 \mathrm{H}), 6.26(\mathrm{~d}$, $J=2.5 \mathrm{~Hz}, 1 \mathrm{H}), 3.75(\mathrm{~s}, 3 \mathrm{H}), 3.67(\mathrm{br} \mathrm{s}, 1 \mathrm{H}), 1.41(\mathrm{~s}, 6 \mathrm{H}) ;{ }^{13} \mathrm{C} \mathrm{NMR}(150 \mathrm{MHz}) \delta 170.6$, $156.5,134.0,119.4,115.4,104.1,100.8,55.5,55.4,25.5$.

\section{7-Chloro-1,2-dihydro-2,2-dimethylquinoxaline (102) and 6-chloro-3,4-dihydro-3,3- dimethyl-2-quinoxalinone ${ }^{68}(103)$.}

The same procedure as described for $\mathbf{5 7}$ was repeated except that a mixture of 4-chloro-2nitro- $N$-[(2-methyl)-1-propenyl]benzenamine (64) (100 mg, $0.44 \mathrm{mmol}), \mathrm{Pd}(\mathrm{dba})_{2}(17 \mathrm{mg}, 0.029$ mmol), dppp (12 mg, $0.029 \mathrm{mmol})$, phen (12 $\mathrm{mg}, 0.067 \mathrm{mmol})$ and DMF (5 mL) was reacted at $70{ }^{\circ} \mathrm{C}$ under $\mathrm{CO}(6 \mathrm{~atm})$ for $2 \mathrm{~h}$. The reaction mixture was diluted with $\mathrm{CH}_{2} \mathrm{Cl}_{2}(30 \mathrm{~mL})$ and washed with brine $(3 \times 30 \mathrm{~mL})$. The combined aqueous phases were extracted with $\mathrm{CH}_{2} \mathrm{Cl}_{2}(1 \mathrm{X}$ $40 \mathrm{~mL})$. The combined organic phases were dried $\left(\mathrm{MgSO}_{4}\right)$, filtered and concentrated. Purification by flash chromatography (hexanes/EtOAc, 7:3) gave 102 (48 mg, $0.25 \mathrm{mmol}, 56 \%$ )

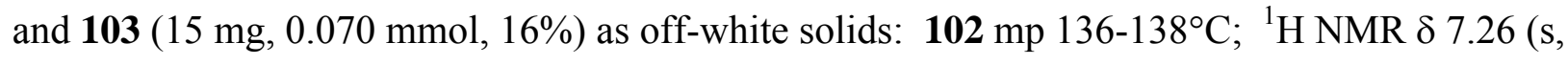


$1 \mathrm{H}), 7.14(\mathrm{~d}, J=8.2 \mathrm{~Hz}, 1 \mathrm{H}), 6.67(\mathrm{dd}, J=8.4$ and $2.2 \mathrm{~Hz}, 1 \mathrm{H}), 6.48(\mathrm{~d}, J=2.2 \mathrm{~Hz}, 1 \mathrm{H}), 3.75$ (s, $1 \mathrm{H}), 1.33$ (s, $6 \mathrm{H}) ;{ }^{13} \mathrm{C}$ NMR $\delta 160.3(-), 137.6(+), 133.8(+), 129.9(+), 128.7(-), 118.2(-)$, 113.3 (-), 50.3 (-), 27.2 (-); IR (neat) 3229, 2972, 1600, 1480, 1451, $1238 \mathrm{~cm}^{-1}$; HRMS (EI) calc. for $\mathrm{C}_{10} \mathrm{H}_{11} \mathrm{ClN}_{2}$ 194.0611, found 194.0611; $103{ }^{1} \mathrm{H}$ NMR $\delta 7.48$ (br s, $1 \mathrm{H}$ ), 6.73 (dd, $J=$ 8.4 and $2.2 \mathrm{~Hz}, 1 \mathrm{H}), 6.67$ (d, $J=2.2 \mathrm{~Hz}, 1 \mathrm{H}), 6.60$ (d, $J=8.2 \mathrm{~Hz}, 1 \mathrm{H}), 3.76$ (br s, $1 \mathrm{H}), 1.41$ (s, $6 \mathrm{H}) ;{ }^{13} \mathrm{C}$ NMR (150 MHz) $\delta 170.9,133.9,128.6,124.2,119.1,115.8,114.1,55.5,25.6$.

\section{6-Chloro-1,2-dihydro-2,2-dimethylquinoxaline (104) and 7-chloro-3,4-dihydro-3,3- dimethyl-2-quinoxalinone ${ }^{68}(105)$.}

The same procedure as described for $\mathbf{5 7}$ was repeated except that a mixture of 5-chloro-2nitro- $N$-[(2-methyl)-1-propenyl]benzenamine (66) (200 mg, $0.88 \mathrm{mmol}), \operatorname{Pd}(\mathrm{dba})_{2}(30 \mathrm{mg}, 0.052$ mmol), dppp (23 mg, $0.056 \mathrm{mmol})$, phen $(21 \mathrm{mg}, 0.117 \mathrm{mmol})$ and DMF $(10 \mathrm{~mL})$ was reacted at $70{ }^{\circ} \mathrm{C}$ under $\mathrm{CO}(6 \mathrm{~atm})$ for $5.5 \mathrm{~h}$. The reaction mixture was diluted with $\mathrm{CH}_{2} \mathrm{Cl}_{2}(20 \mathrm{~mL})$ and washed with brine $(3 \mathrm{X} 30 \mathrm{~mL})$. The combined aqueous phases were extracted with $\mathrm{CH}_{2} \mathrm{Cl}_{2}(1 \mathrm{X}$ $40 \mathrm{~mL})$. The combined organic phases were dried $\left(\mathrm{MgSO}_{4}\right)$, filtered and concentrated.

Purification by flash chromatography (hexanes/EtOAc, 8:2) gave 104 (50 mg, $0.26 \mathrm{mmol}, 29 \%$ ) and 105 (84 mg, $0.40 \mathrm{mmol}, 45 \%)$ as off-white solids: $104 \mathrm{mp} 112-114^{\circ} \mathrm{C} ;{ }^{1} \mathrm{H}$ NMR $\delta 7.29$ (d, $J=1.7 \mathrm{~Hz}, 1 \mathrm{H}), 7.23(\mathrm{~d}, J=2.5 \mathrm{~Hz}, 1 \mathrm{H}), 6.96(\mathrm{dd}, J=8.4$ and $2.2 \mathrm{~Hz}, 1 \mathrm{H}), 6.42(\mathrm{~d}, J=8.4$ Hz, 1 H), 3.78 (br s, 1 H), 1.31 (s, 6 H); ${ }^{13} \mathrm{C}$ NMR $\delta 161.5(-), 135.3(+), 132.1$ (+), $128.4(-)$, $127.3(-), 122.5(+), 114.5(-), 50.4(+), 27.0(-)$; IR (neat) 3249, 2970, 1600, 1485, $1455 \mathrm{~cm}^{-1}$; HRMS (EI) calc. for $\mathrm{C}_{10} \mathrm{H}_{11} \mathrm{ClN}_{2}$ 194.0611, found 194.0619; $105{ }^{1} \mathrm{H}$ NMR $\delta 8.59$ (br s, $1 \mathrm{H}$ ), $6.85(\mathrm{dd}, J=8.4$ and $2.2 \mathrm{~Hz}, 1 \mathrm{H}), 6.76(\mathrm{~d}, J=2.0 \mathrm{~Hz}, 1 \mathrm{H}), 6.59(\mathrm{~d}, J=8.4 \mathrm{~Hz}, 1 \mathrm{H}), 3.72(\mathrm{br} \mathrm{s}$, 
$1 \mathrm{H}), 1.41(\mathrm{~s}, 6 \mathrm{H}) ;{ }^{13} \mathrm{C} \mathrm{NMR}(150 \mathrm{MHz}) \delta 171.3,131.5,126.6,124.1,123.4,115.1,115.0,55.5$, 25.5.

\section{1,2-Dihydro-2,2,5-trimethylquinoxaline (106) and 3,4-dihydro-3,3,8-trimethyl-2- quinoxalinone $^{68}(107)$.}

The same procedure as described for 57 was repeated except that a mixture of 6-methyl2-nitro- $N$-[(2-methyl)-1-propenyl]benzenamine (68) (43 mg, $0.21 \mathrm{mmol}), \operatorname{Pd}(\mathrm{dba})_{2}(7 \mathrm{mg}, 0.012$ mmol), dppp (7 mg, $0.017 \mathrm{mmol})$, phen ( $7 \mathrm{mg}, 0.039 \mathrm{mmol})$ and DMF ( $5 \mathrm{~mL}$ ) was reacted at 70 ${ }^{\circ} \mathrm{C}$ under $\mathrm{CO}(6 \mathrm{~atm})$ for $2 \mathrm{~h}$. The reaction mixture was diluted with $\mathrm{CH}_{2} \mathrm{Cl}_{2}(30 \mathrm{~mL})$ and washed with brine ( 3 X $30 \mathrm{~mL})$. The combined aqueous phases were extracted with $\mathrm{CH}_{2} \mathrm{Cl}_{2}(1 \mathrm{X}$ $30 \mathrm{~mL})$. The combined organic phases were dried $\left(\mathrm{MgSO}_{4}\right)$, filtered and concentrated.

Purification by flash chromatography (hexanes/EtOAc, 8:2) gave 106 (10 mg, $0.057 \mathrm{mmol}, 27 \%$ ) and 107 (17 mg, $0.089 \mathrm{mmol}, 42 \%$ ) as off-white solids: $106 \mathrm{mp} 79-81^{\circ} \mathrm{C} ;{ }^{1} \mathrm{H}$ NMR $\delta 7.29$ (s, 1 H), $6.91(\mathrm{t}, J=7.7 \mathrm{~Hz}, 1 \mathrm{H}), 6.58(\mathrm{~d}, J=7.7 \mathrm{~Hz}, 1 \mathrm{H}), 6.35(\mathrm{~d}, J=7.7 \mathrm{~Hz}, 1 \mathrm{H}), 3.65$ (br s, $1 \mathrm{H})$, $2.41(\mathrm{~s}, 3 \mathrm{H}), 1.31(\mathrm{~s}, 6 \mathrm{H}) ;{ }^{13} \mathrm{C} \mathrm{NMR}(150 \mathrm{MHz}) \delta 158.8(-), 136.5(+), 135.6(+), 129.8(+)$, $128.1(-), 119.9(-), 111.6(-), 49.5(+), 26.7$ (-), $17.2(-)$; IR (neat) 3275, 2960, 1590, 1464, $1289,1160 \mathrm{~cm}^{-1} ; \mathbf{1 0 7}^{1} \mathrm{H}$ NMR $\delta 7.51(\mathrm{br} \mathrm{s}, 1 \mathrm{H}), 6.81(\mathrm{t}, J=7.6 \mathrm{~Hz}, 1 \mathrm{H}), 6.63(\mathrm{~d}, J=6.9 \mathrm{~Hz}, 1$ H), $6.55(\mathrm{~d}, J=7.9 \mathrm{~Hz}, 1 \mathrm{H}), 3.68(\mathrm{br} \mathrm{s}, 1 \mathrm{H}), 2.22(\mathrm{~s}, 3 \mathrm{H}), 1.40(\mathrm{~s}, 6 \mathrm{H}) ;{ }^{13} \mathrm{C} \mathrm{NMR}(150 \mathrm{MHz})$ $\delta 171.0,132.7,123.8,123.2,122.6,121.2,112.5,55.3,25.4,16.4$.

Alternate procedure for 2-methyl-6-nitroaminobenzene ${ }^{69}(67), 1,2-$ dihydro-2,2,5trimethylquinoxaline (106) and 2-isopropyl-4-methylbenzimidazole ${ }^{70}$ (136). To a solution of 2-azido-3-nitrotoluene (135) (1.00 g, $5.6 \mathrm{mmol}$ ) dissolved in diethyl ether (anhydrous, $40 \mathrm{~mL}$ ) was added triphenylphosphine $(1.5 \mathrm{~g}, 5.7 \mathrm{mmol})$. The mixture stirred under argon atmosphere at 
ambient temperature for $1 \mathrm{~h}$. The reaction was then concentrated. To the resulting solid was added $\mathrm{CHCl}_{3}(40 \mathrm{~mL})$ and 2-methylpropanal $(55)(7.0 \mathrm{~mL}, 77.0 \mathrm{mmol})$. The reaction mixture stirred at reflux under argon atmosphere for 6 days. The red color of the reaction, as well as TLC, indicated that the desired enamine had been formed. The reaction was concentrated and the crude solid was used without further purification.

To a solution of the crude enamine dissolved in DMF $(8 \mathrm{~mL})$ in a threaded pressure tube fitted with a pressure head was added $\operatorname{Pd}(\mathrm{dba})_{2}(190 \mathrm{mg}, 0.3 \mathrm{mmol}), \mathrm{dppp}(140 \mathrm{mg}, 0.3 \mathrm{mmol})$ and phen $(120 \mathrm{mg}, 0.7 \mathrm{mmol})$. The tube was flushed 3 times with CO. The reaction was heated and stirred at $70{ }^{\circ} \mathrm{C}$ under $\mathrm{CO}(6 \mathrm{~atm})$ for $21 \mathrm{~h}$. The reaction mixture was concentrated and the product was purified by flash chromatography (hexanes/EtOAc, 9:1, 8:2, 1:1, 3:7 and EtOAc) to give $67(71 \mathrm{mg}, 0.47 \mathrm{mmol}, 8 \%)$ as a yellow solid, $106(106 \mathrm{mg}, 0.6 \mathrm{mmol}, 11 \%)$ as a pale yellow solid and 136 (603 $\mathrm{mg}, 3.46 \mathrm{mmol}, 62 \%)$ as a tan solid.

\section{1,2-Dihydro-2,2,8-trimethylquinoxaline (108) and 3,4-dihydro-3,3,5-trimethyl-2- quinoxalinone $^{68}(109)$.}

The same procedure as described for $\mathbf{5 7}$ was repeated except that a mixture of 3-methyl2-nitro- $N$-[(2-methyl)-1-propenyl]benzenamine (72) (228 mg, $1.1 \mathrm{mmol}), \operatorname{Pd}(\mathrm{dba})_{2}(38 \mathrm{mg}$, $0.067 \mathrm{mmol})$, dppp (27 mg, $0.065 \mathrm{mmol})$, phen ( $24 \mathrm{mg}, 0.13 \mathrm{mmol})$ and DMF (3 mL) was reacted at $70{ }^{\circ} \mathrm{C}$ under $\mathrm{CO}(6 \mathrm{~atm})$ for $14 \mathrm{~h}$. The solvent was removed under high vacuum. Purification by flash chromatography (hexanes/EtOAc, 9:1, 8:2, 7:3 and 1:1) gave 108 (120 mg, $0.69 \mathrm{mmol}, 63 \%)$ and $109(26 \mathrm{mg}, 0.14 \mathrm{mmol}, 12 \%)$ as off-white solids: $108 \mathrm{mp} 95-97^{\circ} \mathrm{C} ;{ }^{1} \mathrm{H}$ NMR $\delta 7.28(\mathrm{~d}, J=2.0 \mathrm{~Hz}, 1 \mathrm{H}), 7.14(\mathrm{~d}, J=7.9 \mathrm{~Hz}, 1 \mathrm{H}), 6.93(\mathrm{~d}, J=7.4 \mathrm{~Hz}, 1 \mathrm{H}), 6.65$ (t, $J=$ $7.7 \mathrm{~Hz}, 1 \mathrm{H}), 3.53$ (br s, $1 \mathrm{H}), 2.10$ (s, $3 \mathrm{H}), 1.34$ (s, $6 \mathrm{H}) ;{ }^{13} \mathrm{C}$ NMR $\delta 159.7$ (-), $134.5(+), 130.7$ 
(+), $129.8(-), 125.5(-), 120.8(+), 117.3(-), 50.2(+), 27.3(-), 16.0(-)$; IR (neat) 2964, 1624, 1600, 1497, 1280, $1082 \mathrm{~cm}^{-1} ; 109 \mathrm{mp} 182-184{ }^{\circ} \mathrm{C} ;{ }^{1} \mathrm{H}$ NMR $\delta 8.82$ (br s, $\left.1 \mathrm{H}\right), 6.79$ (dd, $J=6.7$ and $2.0 \mathrm{~Hz}, 1 \mathrm{H}), 6.73-6.63(\mathrm{~m}, 2 \mathrm{H}), 3.58(\mathrm{br} \mathrm{s}, 1 \mathrm{H}), 2.17$ (s, $3 \mathrm{H}), 1.43(\mathrm{~s}, 6 \mathrm{H}) ;{ }^{13} \mathrm{C} \mathrm{NMR}$ $(150 \mathrm{MHz}) \delta 171.4,130.9,125.2,125.1,122.1,118.8,113.2,55.4,25.8,16.6$.

\section{(3,4-Dihydro-3,3-dimethylquinoxalin-6-yl)phenylmethanone (110).}

The same procedure as described for $\mathbf{5 7}$ was repeated except that a mixture of [4-(2methylpropenylamino)-3-nitrophenyl]phenylmethanone (74) (120 mg, $0.40 \mathrm{mmol}), \mathrm{Pd}(\mathrm{dba})_{2}(14$ $\mathrm{mg}, 0.024 \mathrm{mmol})$, dppp (10 mg, $0.024 \mathrm{mmol})$, phen $(9 \mathrm{mg}, 0.048 \mathrm{mmol})$ and DMF ( $5 \mathrm{~mL})$ was reacted at $70{ }^{\circ} \mathrm{C}$ under $\mathrm{CO}(6 \mathrm{~atm})$ for $18 \mathrm{~h}$. The reaction mixture was filtered through Celite with EtOAc and the filtrate was concentrated. After numerous attempts to purify the product by flash chromatography, the yellow solid that was isolated was tentatively determined to be $\mathbf{1 1 0}$ $(<56 \mathrm{mg},<0.2 \mathrm{mmol},<52 \%):{ }^{1} \mathrm{H}$ NMR $\delta 7.79$ (dd, $J=8.4$ and $\left.1.5 \mathrm{~Hz}, 2 \mathrm{H}\right), 7.57$ (t, $J=7.4 \mathrm{~Hz}$, $1 \mathrm{H}), 7.46$ (t, $J=7.6 \mathrm{~Hz}, 2 \mathrm{H}), 7.39$ (d, $J=1.7 \mathrm{~Hz}, 1 \mathrm{H}), 7.30$ (d, $J=7.9 \mathrm{~Hz}, 1 \mathrm{H}), 7.08$ (dd, $J=$ 7.9 and $1.8 \mathrm{~Hz}, 1 \mathrm{H}), 7.03$ (d, $J=1.7 \mathrm{~Hz}, 1 \mathrm{H}), 4.08$ (br s, $1 \mathrm{H}), 1.34(\mathrm{~s}, 6 \mathrm{H}) ;{ }^{13} \mathrm{C}$ NMR $\delta 196.4$ $(+), 163.0(-), 137.6(+), 137.5(+), 136.8(+), 134.3(+), 132.2(-), 129.9(-), 128.1(-), 127.1(-)$, $120.8(-), 115.0(-), 50.5(+), 27.1(-)$.

\section{Methyl 3,4-dihydro-3,3-dimethylquinoxaline-6-carboxylate (111) and methyl 1,2,3,4- tetrahydro-3,3-dimethyl-2-oxoquinoxaline-6-carboxylate (112).}

The same procedure as described for $\mathbf{5 7}$ was repeated except that a mixture of methyl 4(2-methylpropenylamino)-3-nitrobenzoate (76) (250 mg, $1.0 \mathrm{mmol}), \mathrm{Pd}(\mathrm{dba})_{2}$ (35 mg, 0.061 mmol), dppp (25 mg, $0.061 \mathrm{mmol})$, phen $(22 \mathrm{mg}, 0.12 \mathrm{mmol})$ and DMF $(5 \mathrm{~mL})$ was reacted at 70 
${ }^{\circ} \mathrm{C}$ under $\mathrm{CO}(6 \mathrm{~atm})$ for $17 \mathrm{~h}$. The reaction mixture was then concentrated. Purification by flash chromatography (hexanes/EtOAc, 8:2 and 6:4) gave an inseparable mixture of 111 (6 mg, 0.03

mmol, 3\%) and 112 (5 mg, $0.02 \mathrm{mmol}, 2 \%$ ) as a tan solid ${ }^{71}$ : data for the mixture ${ }^{1} \mathrm{H}$ NMR $\delta 8.93$ (s, $1 \mathrm{H}), 8.53(\mathrm{~s}, 1 \mathrm{H}), 7.97(\mathrm{~d}, J=8.2 \mathrm{~Hz}, 1 \mathrm{H}), 7.56(\mathrm{dd}, J=8.2$ and $1.5 \mathrm{~Hz}, 1 \mathrm{H}), 7.49$ (dd, $J=$ 8.2 and $1.5 \mathrm{~Hz}, 1 \mathrm{H}), 7.29(\mathrm{~d}, J=1.2 \mathrm{~Hz}, 1 \mathrm{H}), 6.98(\mathrm{~d}, J=8.2 \mathrm{~Hz}, 1 \mathrm{H}), 4.08$ (br s, $1 \mathrm{H}), 3.94$ (br s, $1 \mathrm{H}), 3.88(\mathrm{~s}, 6 \mathrm{H}), 1.81(\mathrm{~s}, 6 \mathrm{H}), 1.71(\mathrm{~s}, 6 \mathrm{H})$ (Note: One proton signal is missing. It is most likely masked by the solvent residual peak at $7.27 \mathrm{ppm}$ ).

7'-Methoxy-spiro[cyclohexane-1,2'(1'H)quinoxaline] (113) and 1',4'-dihydro-7'-methoxyspiro[cyclohexane-1,2'(3’H)quinoxalin]3'-one (114).

The same procedure as described for $\mathbf{5 7}$ was repeated except that a mixture of 4methoxy-2-nitro- $N$-(cyclohexylmethylene)benzenamine (78) (201 mg, $0.77 \mathrm{mmol}), \mathrm{Pd}(\mathrm{dba})_{2}(27$ mg, $0.047 \mathrm{mmol})$, dppp (19 mg, $0.046 \mathrm{mmol})$, phen (19 mg, $0.105 \mathrm{mmol})$ and DMF (10 mL) was reacted at $70{ }^{\circ} \mathrm{C}$ under $\mathrm{CO}(6 \mathrm{~atm})$ for $4.5 \mathrm{~h}$. The reaction mixture was diluted with $\mathrm{CH}_{2} \mathrm{Cl}_{2}(40$ $\mathrm{mL})$ and washed with brine ( $4 \mathrm{X} 50 \mathrm{~mL})$. The combined aqueous phases were extracted with $\mathrm{CH}_{2} \mathrm{Cl}_{2}(1 \mathrm{X} 50 \mathrm{~mL})$. The combined organic phases were dried $\left(\mathrm{MgSO}_{4}\right)$, filtered and concentrated. Purification by flash chromatography (hexanes/EtOAc, 7:3) gave 113 (123 mg, $0.534 \mathrm{mmol}, 70 \%)$ and $114(24 \mathrm{mg}, 0.097 \mathrm{mmol}, 13 \%)$ as off-white solids: $113 \mathrm{mp} 141-142^{\circ} \mathrm{C}$;

${ }^{1} \mathrm{H}$ NMR $\delta 7.23$ (s, $\left.1 \mathrm{H}\right), 7.15(\mathrm{~d}, J=8.4 \mathrm{~Hz}, 1 \mathrm{H}), 6.27(\mathrm{dd}, J=8.4$ and $2.5 \mathrm{~Hz}, 1 \mathrm{H}), 6.08$ (d, $J$ $=2.7 \mathrm{~Hz}, 1 \mathrm{H}), 4.06(\mathrm{br} \mathrm{s}, 1 \mathrm{H}), 3.76(\mathrm{~s}, 3 \mathrm{H}), 1.80-1.30(\mathrm{~m}, 10 \mathrm{H}) ;{ }^{13} \mathrm{C}$ NMR $\delta 160.0(+), 157.7$ $(-), 137.7(+), 128.5(-), 126.5(+), 103.4(-), 99.0(-), 55.1(-), 51.4(+), 34.7(+), 25.1(+), 20.3$ (+); IR (neat) 3243, 2927, 1612, 1582, 1466, 1308, 1257, $1102 \mathrm{~cm}^{-1}$; HRMS (EI) calc. for

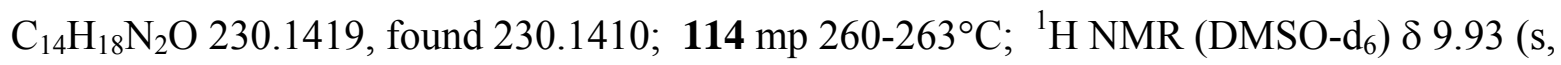


1H), $6.59(\mathrm{~d}, J=8.4 \mathrm{~Hz}, 1 \mathrm{H}), 6.52(\mathrm{~d}, J=2.5 \mathrm{~Hz}, 1 \mathrm{H}), 6.17(\mathrm{dd}, J=8.6$ and $2.5 \mathrm{~Hz}, 1 \mathrm{H}), 5.96$

(s, $1 \mathrm{H}), 3.63(\mathrm{~s}, 3 \mathrm{H}), 1.7-1.4(\mathrm{~m}, 10 \mathrm{H}) ;{ }^{13} \mathrm{C}$ NMR $\left(\right.$ DMSO-d $\left._{6}\right) \delta 169.5(+), 155.3(+), 134.4$ $(+), 120.0(+), 116.6(-), 102.8(-), 100.3(-), 55.6(+), 54.9(-), 31.4(+), 25.0(+), 19.9(+)$; IR (neat) $3368,2929,1672,1518,1259,1015 \mathrm{~cm}^{-1}$; HRMS (EI) calc for $\mathrm{C}_{14} \mathrm{H}_{18} \mathrm{~N}_{2} \mathrm{O}_{2} 246.1368$, found 246.1371 .

\section{1,2-Dihydro-2,2-diphenyl-7-methoxyquinoxaline (115).}

The same procedure as described for $\mathbf{5 7}$ was repeated except that a mixture of 4methoxy-2-nitro- $N$-(2,2-diphenylethenyl)benzenamine (80) (96 mg, $0.28 \mathrm{mmol}), \operatorname{Pd}(\mathrm{dba})_{2}(10$ $\mathrm{mg}, 0.017 \mathrm{mmol})$, dppp (7 mg, $0.017 \mathrm{mmol})$, phen ( $7 \mathrm{mg}, 0.039 \mathrm{mmol})$ and DMF (4 mL) was reacted at $70{ }^{\circ} \mathrm{C}$ under $\mathrm{CO}(6 \mathrm{~atm})$ for $18 \mathrm{~h}$. The solvent was removed under high vacuum. Purification by flash chromatography (hexanes/EtOAc, 8:2) gave 115 (60 mg, 0.19 mmol, 69\%) as a tan solid: $\mathrm{mp} 164-166^{\circ} \mathrm{C} ;{ }^{1} \mathrm{H} \mathrm{NMR} \delta 7.59(\mathrm{~d}, J=2.5 \mathrm{~Hz}, 1 \mathrm{H}), 7.40-7.25(\mathrm{~m}, 10 \mathrm{H}), 7.19$ $(\mathrm{d}, J=8.7 \mathrm{~Hz}, 1 \mathrm{H}), 6.27(\mathrm{dd}, J=8.4$ and $2.5 \mathrm{~Hz}, 1 \mathrm{H}), 6.09(\mathrm{~d}, J=2.5 \mathrm{~Hz}, 1 \mathrm{H}), 4.43(\mathrm{br} \mathrm{s}, 1 \mathrm{H})$, $3.75(\mathrm{~s}, 3 \mathrm{H}) ;{ }^{13} \mathrm{C}$ NMR $\delta 160.5(+), 153.3(-), 144.1(+), 136.5(+), 129.1(-), 128.6(-), 127.6$ (-), $127.4(-), 124.7(+), 103.8(-), 98.4(-), 62.5(+), 55.2(-)$; IR (neat) 3232, 2998, 2930, 1594, 1486, 1293, 1224, 1174, $1033 \mathrm{~cm}^{-1}$; HRMS (EI) calc. for $\mathrm{C}_{21} \mathrm{H}_{18} \mathrm{~N}_{2} \mathrm{O} 314.1419$, found 314.1409.

\section{7-Chloro-2-phenylquinoxaline ${ }^{19}$ (116) and 6-chloro-3-phenyl-2-quinoxalinol ${ }^{72}(117)$.}

The same procedure as described for $\mathbf{5 7}$ was repeated except that a mixture of $(E)$ and (Z)-4-chloro-2-nitro- $N$-(2-phenylethylene)benzenamine (82) (106 mg, $0.39 \mathrm{mmol}), \mathrm{Pd}(\mathrm{dba})_{2}$ (13 mg, $0.023 \mathrm{mmol})$, dppp (10 mg, $0.024 \mathrm{mmol})$, phen $(10 \mathrm{mg}, 0.055 \mathrm{mmol})$ and DMF (10 mL) was reacted at $70{ }^{\circ} \mathrm{C}$ under $\mathrm{CO}(6 \mathrm{~atm})$ for $48 \mathrm{~h}$. The reaction mixture was diluted with $\mathrm{CH}_{2} \mathrm{Cl}_{2}(20$ 
$\mathrm{mL})$ and washed with brine $(3 \times 30 \mathrm{~mL})$. The combined aqueous phases were extracted with $\mathrm{CH}_{2} \mathrm{Cl}_{2}(1 \mathrm{X} 30 \mathrm{~mL})$. The combined organic phases were dried $\left(\mathrm{MgSO}_{4}\right)$, filtered and concentrated. Purification by flash chromatography (hexanes/EtOAc, 9:1) gave 116 (23 mg, $0.096 \mathrm{mmol}, 25 \%$ ) and 117 (14 mg, $0.055 \mathrm{mmol}, 14 \%$ ) as off-white solids: $116{ }^{1} \mathrm{H}$ NMR $\delta 8.91$ (s, $1 \mathrm{H}), 8.69(\mathrm{~d}, J=2.2 \mathrm{~Hz}, 1 \mathrm{H}), 8.08(\mathrm{~d}, J=8.9 \mathrm{~Hz}, 1 \mathrm{H}), 8.00-7.95(\mathrm{~m}, 2 \mathrm{H}), 7.76(\mathrm{dd}, J=8.9$ and $2.2 \mathrm{~Hz}, 1 \mathrm{H}), 7.62-7.51(\mathrm{~m}, 3 \mathrm{H}) ;{ }^{13} \mathrm{C} \mathrm{NMR}(150 \mathrm{MHz}) \delta 147.5(-) .143 .0(+), 139.8,137.8$, $137.0(+), 132.2(-), 131.4(-), 130.6(-), 129.5(+), 129.4(-), 128.8(-), 119.0(-) ; 117{ }^{1} \mathrm{H}$ NMR $\delta$ $9.32(\mathrm{~s}, 1 \mathrm{H}), 8.22-8.18$ (m, $2 \mathrm{H}), 8.16(\mathrm{~d}, J=2.2 \mathrm{~Hz}, 1 \mathrm{H}), 8.06(\mathrm{~d}, J=8.9 \mathrm{~Hz}, 1 \mathrm{H}), 7.69$ (dd, $J$ $=8.9$ and $2.2 \mathrm{~Hz}, 1 \mathrm{H}), 7.60-7.56(\mathrm{~m}, 3 \mathrm{H}) ;{ }^{13} \mathrm{C} \mathrm{NMR}(150 \mathrm{MHz}) \delta 152.6,143.4,142.7,140.1$, $136.3,136.1,130.6,130.5,130.4,129.2,128.5,127.6$.

\section{1,2-Dihydro-2,2-dimethylpyrido[2,3-b]pyrazine (118) and 1,2-dihydro-2,2- dimethylpyrido[2,3-b]pyrazin-3-one (119).}

The same procedure as described for 57 was repeated except that a mixture of 3-nitro- $N$ [(2-methyl)-1-propenyl]-2-pyridinamine (87) (100 mg, $0.52 \mathrm{mmol}), \mathrm{Pd}(\mathrm{dba})_{2}(18 \mathrm{mg}, 0.031$ mmol), dppp (14 mg, $0.034 \mathrm{mmol})$, phen (13 mg, $0.072 \mathrm{mmol}$ ) and DMF (5 mL) was reacted at $70{ }^{\circ} \mathrm{C}$ under $\mathrm{CO}(6 \mathrm{~atm})$ for $6 \mathrm{~h}$. The reaction mixture was diluted with EtOAc $(30 \mathrm{~mL})$ and washed with brine $(3 \mathrm{X} 30 \mathrm{~mL})$. The combined aqueous phases were extracted with EtOAc (1 X $30 \mathrm{~mL})$. The combined organic phases were dried $\left(\mathrm{MgSO}_{4}\right)$, filtered and concentrated.

Purification by flash chromatography (hexanes/EtOAc, 7:3) gave 118 (28 mg, 0.17 mmol, 34\%) and 119 (5 mg, $0.028 \mathrm{mmol}, 6 \%)$ as off-white solids: $118{ }^{1} \mathrm{H}$ NMR $\delta 9.28(\mathrm{~s}, 1 \mathrm{H}), 7.57(\mathrm{dd}, J=$ 4.7 and 1.5 Hz, $1 \mathrm{H}), 6.85-6.70(\mathrm{~m}, 2 \mathrm{H}), 4.03$ (br s, $1 \mathrm{H}), 1.81(\mathrm{~s}, 6 \mathrm{H}) ;{ }^{13} \mathrm{C} \mathrm{NMR} \delta 157.5(-)$, $146.2(+), 137.5(-), 131.9(+), 119.6(-), 115.2(-), 80.0(+), 27.5(-) ;$ IR (neat) 2976, 1674, 
$1609,1444,1343,1245 \mathrm{~cm}^{-1} ; 119 \mathrm{mp} 202-205^{\circ} \mathrm{C} ;{ }^{1} \mathrm{H}$ NMR $\delta 9.24$ (br s, $\left.1 \mathrm{H}\right), 7.83(\mathrm{dd}, J=4.9$ and $1.5 \mathrm{~Hz}, 1 \mathrm{H}), 6.94(\mathrm{dd}, J=7.9$ and $1.5 \mathrm{~Hz}, 1 \mathrm{H}), 6.84(\mathrm{dd}, J=7.7$ and $4.9 \mathrm{~Hz}, 1 \mathrm{H}), 3.72$ (br s, $1 \mathrm{H}), 1.45(\mathrm{~s}, 6 \mathrm{~h}) ;{ }^{13} \mathrm{C}$ NMR $\delta 171.0(+), 140.3(+), 137.9(-), 128.5(+), 120.2(-), 119.1(-)$, $56.0(+), 26.1(-)$; IR (neat) 3310, 1683, 1558, 1458, $1289 \mathrm{~cm}^{-1} ;$ HRMS (EI) calc. for $\mathrm{C}_{9} \mathrm{H}_{11} \mathrm{~N}_{3} \mathrm{O}$ 177.0902, found 177.0899.

1-Hydroxyphenazine ${ }^{69}(120)$, 1,2,3,4-tetrahydrophenazine ${ }^{73}(121)$ and 3,4-dihydrophenazin1(2H)-one ${ }^{74}$ (122).

The same procedure as described for 57 was repeated except that a mixture of 2-(2nitrophenylamino)-2-cyclohexen-1-one (90) (100 mg, $0.4 \mathrm{mmol}), \mathrm{Pd}(\mathrm{dba})_{2}(15 \mathrm{mg}, 0.026 \mathrm{mmol})$, dppp (11 mg, $0.027 \mathrm{mmol})$, phen $(10 \mathrm{mg}, 0.061 \mathrm{mmol})$ and DMF $(2 \mathrm{~mL})$ was reacted at $70{ }^{\circ} \mathrm{C}$ under CO (6 atm) for $22 \mathrm{~h}$. The solvent was removed under high vacuum. Purification by flash chromatography (hexanes/EtOAc, 9:1, 8:2, 7:3, 1:1 and 3:7) gave 120 (5 mg, 0.025 mmol, 6\%), 121 (6 mg, $0.033 \mathrm{mmol}, 8 \%)$ and 122 (13 mg, $0.066 \mathrm{mmol}, 15 \%)$ as brown solids: $122{ }^{1} \mathrm{H}$ NMR $\delta 8.33(\mathrm{dd}, J=8.4$ and $1.5 \mathrm{~Hz}, 1 \mathrm{H}), 8.07(\mathrm{dd}, J=8.2$ and $1.5 \mathrm{~Hz}, 1 \mathrm{H}), 7.88(\mathrm{dt}, J=6.9$ and 1.5 $\mathrm{Hz}, 1 \mathrm{H}), 7.81(\mathrm{dt}, J=6.9$ and $1.5 \mathrm{~Hz}, 1 \mathrm{H}), 3.43(\mathrm{t}, J=6.2 \mathrm{~Hz}, 2 \mathrm{H}), 3.01(\mathrm{t}, J=6.2 \mathrm{~Hz}, 2 \mathrm{H})$, 2.37 (pentet, $J=6.4 \mathrm{~Hz}, 2 \mathrm{H}$ ).

Alternate procedure A for 120. Compound $122(25 \mathrm{mg}, 0.13 \mathrm{mmol}), 10 \% \mathrm{Pd} / \mathrm{C}(20$ $\mathrm{mg}, 0.02 \mathrm{mmol} \mathrm{Pd})$, 1,2,4-trimethylbenzene $(0.15 \mathrm{~mL}, 1.1 \mathrm{mmol})$ and diphenyl ether $(1.0 \mathrm{~mL})$ were combined in a threaded pressure tube fitted with a Teflon cap. The reaction was heated and stirred at $230{ }^{\circ} \mathrm{C}$ for $20 \mathrm{~h}$. The mixture was then filtered through silica gel and washed with EtOAc. The filtrate was then concentrated. The remaining diphenyl ether was removed by bulbto-bulb distillation to give 120 ( $5 \mathrm{mg}, 0.025 \mathrm{mmol}, 20 \%)$ as a brown solid. 
Alternate procedure B for 120. The same procedure as described for $\mathbf{5 7}$ was repeated except that a mixture of 3-(2-nitrophenylamino)-2-cyclohexen-1-one (92) (302 mg, $1.3 \mathrm{mmol}$ ), $\operatorname{Pd}(\mathrm{dba})_{2}(45 \mathrm{mg}, 0.08 \mathrm{mmol})$, dppp (33 mg, $\left.0.08 \mathrm{mmol}\right)$, phen (30 mg, $\left.0.17 \mathrm{mmol}\right)$ and DMF (4 $\mathrm{mL})$ was reacted at $120{ }^{\circ} \mathrm{C}$ under $\mathrm{CO}(6 \mathrm{~atm})$ for $22 \mathrm{~h}$. The mixture was then filtered through Celite and the filtrate was concentrated under high vacuum. Purification by flash chromatography (hexanes/EtOAc, 8:2, 7:3, 1:1 and EtOAc) gave 120 (67 mg, $0.34 \mathrm{mmol}, 26 \%$ ) as a brown solid.

\section{2-Acetylquinoxaline (123).}

The same procedure as described for $\mathbf{5 7}$ was repeated except that a mixture of (Z)-4-(2nitrophenylamino)-3-buten-2-one (95) (200 mg, $1.0 \mathrm{mmol}$ ), $\mathrm{Pd}(\mathrm{dba})_{2}$ (33 mg, $0.06 \mathrm{mmol}$ ), dppp (24 mg, $0.06 \mathrm{mmol})$, phen $(23 \mathrm{mg}, 0.13 \mathrm{mmol})$ and $\mathrm{DMF}(10 \mathrm{~mL})$ was reacted at $90{ }^{\circ} \mathrm{C}$ under $\mathrm{CO}(6 \mathrm{~atm})$ for $44 \mathrm{~h}$. The mixture was diluted with $\mathrm{CH}_{2} \mathrm{Cl}_{2}(30 \mathrm{~mL})$ and washed with $\mathrm{H}_{2} \mathrm{O}(3 \mathrm{X}$ $30 \mathrm{~mL})$. The combined aqueous phases were extracted with $\mathrm{CH}_{2} \mathrm{Cl}_{2}(30 \mathrm{~mL})$. The combined organic phases were dried $\left(\mathrm{MgSO}_{4}\right)$, filtered and concentrated. Purification by flash chromatography (hexanes/EtOAc, 8:2, 7:3, 1:1) gave $123(10 \mathrm{mg}, 0.06 \mathrm{mmol}, 6 \%)$ as a brown solid: ${ }^{1} \mathrm{H}$ NMR $\delta 9.51(\mathrm{~s}, 1 \mathrm{H}), 8.23-8.17$ (m, $\left.2 \mathrm{H}\right), 7.94-7.84(\mathrm{~m}, 2 \mathrm{H}), 2.87(\mathrm{~s}, 3 \mathrm{H}) ;{ }^{13} \mathrm{C}$ NMR (150 MHz) $\delta 199.8,146.6,143.9,143.1(-), 141.1,132.2(-), 130.7(-), 130.5(-), 129.4(-), 25.5$.

\section{2-Acetyl-6-methylquinoxaline (124) and 2-acetyl-7-methylquinoxaline (125).}

The same procedure as described for 57 was repeated except that a mixture of (Z)-4-(4methyl-2-nitrophenylamino)-3-buten-2-one (96) (100 mg, 0.45 mmol), $\mathrm{Pd}(\mathrm{dba})_{2}$ (16 mg, 0.03 mmol), dppp (11 mg, $0.03 \mathrm{mmol})$, phen $(10 \mathrm{mg}, 0.06 \mathrm{mmol})$ and DMF $(2 \mathrm{~mL})$ was reacted at 70 
${ }^{\circ} \mathrm{C}$ under $\mathrm{CO}(6 \mathrm{~atm})$ for $21 \mathrm{~h}$. The solvents were removed under reduced pressure. Purification by flash chromatography (hexanes/EtOAc, 9:1, 8:2, 7:3, 1:1, 3:7 and EtOAc) gave an inseparable mixture of 124 and $\mathbf{1 2 5}(11 \mathrm{mg}, 0.06 \mathrm{mmol}, 13 \%)$ as a pale yellow solid: data for the mixture ${ }^{1} \mathrm{H}$ NMR $\delta 9.46$ (s, $1 \mathrm{H}), 9.43(\mathrm{~s}, 1 \mathrm{H}), 8.08(\mathrm{~d}, J=8.6 \mathrm{~Hz}, 1 \mathrm{H}), 8.06(\mathrm{~d}, J=8.7 \mathrm{~Hz}, 1 \mathrm{H}), 7.98$ (s, 1 H), $7.94(\mathrm{~s}, 1 \mathrm{H}), 7.71$ (apparent dt, $J=9.1$ and $2.0 \mathrm{~Hz}, 2 \mathrm{H}), 2.85(\mathrm{~s}, 6 \mathrm{H}), 2.65(\mathrm{~s}, 6 \mathrm{H}) ;{ }^{13} \mathrm{C}$ NMR (150 MHz) $\delta 199.9,199.8,146.6,146.0,144.0,143.1,142.4,142.2,141.4,141.2,139.5$, 134.6, 133.1, 130.0, 129.2, 128.9, 128.4, 128.3, 25.5, 25.5, 22.1, 21.8 .

Alternate procedure A for $\mathbf{1 2 4}$ and 125. The same procedure as described for $\mathbf{5 7}$ was repeated except that a mixture of (Z)-4-(5-methyl-2-nitrophenylamino)-3-buten-2-one (97) (500 mg, $2.3 \mathrm{mmol}$ ), Pd(dba) 2 (78 mg, $0.14 \mathrm{mmol})$, dppp (56 mg, $0.14 \mathrm{mmol})$, phen (49 mg, 0.27 $\mathrm{mmol})$ and $\operatorname{DMF}(2 \mathrm{~mL})$ was reacted at $70{ }^{\circ} \mathrm{C}$ under $\mathrm{CO}(6 \mathrm{~atm})$ for $20 \mathrm{~h}$. The solvents were removed under reduced pressure. Purification by flash chromatography (hexanes/EtOAc, 9:1, 8:2, 7:3, 1:1, 3:7 and EtOAc) gave an inseparable mixture of 124 and 125 (15 $\mathrm{mg}, 0.08 \mathrm{mmol}$, $4 \%)$ as a pale yellow solid.

Alternate procedure B for 124 and 125. Compound 153 (205 mg, $0.95 \mathrm{mmol}), p$ toluenesulfonic acid $(10 \mathrm{mg})$ and ethanol $(50 \mathrm{~mL})$ were combined and heated to reflux for $27 \mathrm{~h}$. The reaction mixture was then concentrated. Purification by flash chromatography (hexanes/EtOAc, 9:1, 8:2, 7:3, 6:4 and 1:1) gave an inseparable mixture of 124 and 125 (11 mg, $0.06 \mathrm{mmol}, 6 \%$ ) as a pale yellow solid.

\section{2-Azido-1-nitrobenzene ${ }^{75}$ (131).}

To a solution of 2-nitroaminobenzene (52) (5.00 g, $36.2 \mathrm{mmol}$ ) dissolved in $\mathrm{H}_{2} \mathrm{O}$ (300 $\mathrm{mL}$ ) at $0{ }^{\circ} \mathrm{C}$ was added $\mathrm{HCl}$ (concentrated, $75 \mathrm{~mL}$ ). Small amounts of ice were added 
periodically to keep the solution at $0{ }^{\circ} \mathrm{C}$. The solution of amine hydrochloride stirred for 5 minutes. $\mathrm{NaNO}_{2}\left(3.00 \mathrm{~g}, 43.5 \mathrm{mmol}\right.$ in $\left.10 \mathrm{~mL} \mathrm{H}_{2} \mathrm{O}\right)$ was added to the cold solution and the reaction stirred for $3 \mathrm{~h}$. The remaining insoluble solid was removed by filtration. To the filtrate was added $\mathrm{NaN}_{3}\left(2.90 \mathrm{~g}, 44.6 \mathrm{mmol}\right.$ in $\left.10 \mathrm{~mL} \mathrm{H}_{2} \mathrm{O}\right)$. Small amounts of diethyl ether were used to stop the foaming that resulted. The solution was stirred for $2 \mathrm{~h}$. The resulting solid was removed by filtration and washed with cold diethyl ether to give 131 (4.75 g, $29.0 \mathrm{mmol}, 80 \%)$ as an off-white solid: ${ }^{1} \mathrm{H}$ NMR $\delta 7.95(\mathrm{dd}, J=8.2$ and $1.2 \mathrm{~Hz}, 1 \mathrm{H}), 7.63(\mathrm{dt}, J=7.8$ and $1.5 \mathrm{~Hz}$, $1 \mathrm{H}), 7.35(\mathrm{dd}, J=8.2$ and $1.0 \mathrm{~Hz}, 1 \mathrm{H}), 7.27(\mathrm{dt}, J=7.8$ and $1.0 \mathrm{~Hz}, 1 \mathrm{H}) ;{ }^{13} \mathrm{C} \mathrm{NMR}(150 \mathrm{MHz})$ $\delta 140.8(+), 134.7(+), 134.0(-), 126.0(-), 124.9(-), 120.7(-)$.

\section{2-Pentylquinoxaline (132), 2-pentylquinoxaline-1-oxide (133) and 2-hexylbenzimidazole ${ }^{76}$ (134).}

To a solution of 2-azidonitrobenzene (131) $(500 \mathrm{mg}, 3.1 \mathrm{mmol})$ dissolved in diethyl ether (anhydrous, $20 \mathrm{~mL}$ ) was added triphenylphosphine $(800 \mathrm{mg}, 3.1 \mathrm{mmol})$. The mixture stirred under argon atmosphere at ambient temperature for $1 \mathrm{~h}$. The reaction was then concentrated. To the resulting solid was added $\mathrm{CHCl}_{3}(25 \mathrm{~mL})$ and heptanal $(\mathbf{8 3})(4.0 \mathrm{~mL}, 29.8 \mathrm{mmol})$. The reaction mixture stirred at reflux under argon atmosphere for 7 days. The red color of the reaction, as well as TLC, indicated that the desired enamine had been formed. The reaction was concentrated and the crude solid was used without further purification.

To a solution of the crude enamine dissolved in DMF $(10 \mathrm{~mL})$ in a threaded pressure tube fitted with a pressure head was added $\operatorname{Pd}(\mathrm{dba})_{2}(110 \mathrm{mg}, 0.2 \mathrm{mmol})$, dppp (80 $\left.\mathrm{mg}, 0.2 \mathrm{mmol}\right)$ and phen $(70 \mathrm{mg}, 0.4 \mathrm{mmol})$. The tube was flushed 3 times with $\mathrm{CO}$. The reaction was heated and stirred at $70{ }^{\circ} \mathrm{C}$ under $\mathrm{CO}(6 \mathrm{~atm})$ for $72 \mathrm{~h}$. The reaction mixture was concentrated and the 
product was purified by flash chromatography (hexanes/EtOAc, 8:2, 7:3, 6:4, 1:1 and 3:7) to give 132 (153 mg, $0.76 \mathrm{mmol}, 25 \%$ ) as a yellow oil, 133 (54 $\mathrm{mg}, 0.25 \mathrm{mmol}, 8 \%$ ) as an off-white solid and 134 (84 mg, $0.42 \mathrm{mmol}, 14 \%$ ) as a tan solid: $132{ }^{1} \mathrm{H}$ NMR $\delta 8.75(\mathrm{~s}, 1 \mathrm{H}), 8.06$ (apparent triplet with further fine splitting, $J=9.4 \mathrm{~Hz}, 2 \mathrm{H}), 7.76(\mathrm{dt}, J=6.7$ and $1.7 \mathrm{~Hz}, 1 \mathrm{H}$ ) partially overlapping $7.71(\mathrm{dt}, J=6.9$ and $1.7 \mathrm{~Hz}, 1 \mathrm{H}), 3.02(\mathrm{t}, J=7.7 \mathrm{~Hz}, 2 \mathrm{H}), 1.86$ (pentet, $J$ $=7.6 \mathrm{~Hz}, 2 \mathrm{H}), 1.47-1.32(\mathrm{~m}, 4 \mathrm{H}), 0.91(\mathrm{t}, J=7.0 \mathrm{~Hz}, 3 \mathrm{H}) ;{ }^{13} \mathrm{C} \mathrm{NMR}(150 \mathrm{MHz}) \delta 157.6(+)$, $145.7(-), 142.1(+), 141.1(+), 129.8(-), 129.1(-), 128.8(-), 128.7(-), 36.4(+), 31.5(+), 29.1$ (+), $22.4(+), 13.9$ (-); IR (neat) 2957, 2927, 2857, 1561, 1492, 1126, $761 \mathrm{~cm}^{-1} ; 133 \mathrm{mp} 32-34$ ${ }^{\circ} \mathrm{C} ;{ }^{1} \mathrm{H}$ NMR $\delta 8.69(\mathrm{~s}, 1 \mathrm{H}), 8.61$ (apparent doublet with further fine splitting, $J=10.1 \mathrm{~Hz}, 1$ H), 8.10 (apparent doublet with further fine splitting, $J=9.7 \mathrm{~Hz}, 1 \mathrm{H}), 7.81-7.71(\mathrm{~m}, 2 \mathrm{H}), 3.08$ (t, $J=7.7 \mathrm{~Hz}, 2 \mathrm{H}), 1.84$ (pentet, $J=7.4 \mathrm{~Hz}, 2 \mathrm{H}), 1.48-1.38$ (m, $4 \mathrm{H}), 0.93$ (t, $J=6.9 \mathrm{~Hz}, 3 \mathrm{H}$ ); ${ }^{13} \mathrm{C}$ NMR (150 MHz) $\delta 146.8(-), 144.4(+), 143.0(+), 137.0(+), 130.5(-), 130.0(-), 129.9(-)$, $118.7(-), 31.7(+), 28.7(+), 25.2(+), 22.3(+), 13.9(-)$; IR (neat) 2957, 2927, 2860, 1579, 1494, $1359,1302,766 \mathrm{~cm}^{-1}$.

\section{2-Azido-3-nitrotoluene ${ }^{77}$ (135).}

The same procedure as described for $\mathbf{1 3 1}$ was repeated except that a mixture of 2-methyl6-nitroaminobenzene (67) $(3.00 \mathrm{~g}, 19.7 \mathrm{mmol}), \mathrm{H}_{2} \mathrm{O}(100 \mathrm{~mL}), \mathrm{HCl}$ (concentrated, $\left.100 \mathrm{~mL}\right)$, $\mathrm{NaNO}_{2}(1.70 \mathrm{~g}, 24.6 \mathrm{mmol})$ and $\mathrm{NaN}_{3}(2.50 \mathrm{~g}, 38.5 \mathrm{mmol})$ gave $135(2.62 \mathrm{~g}, 14.7 \mathrm{mmol}, 75 \%)$ as a pale yellow solid: ${ }^{1} \mathrm{H}$ NMR $\delta 7.80(\mathrm{~d}, J=8.2 \mathrm{~Hz}, 1 \mathrm{H}), 7.45(\mathrm{~d}, J=7.4 \mathrm{~Hz}, 1 \mathrm{H}), 7.21(\mathrm{t}, J=$ $7.9 \mathrm{~Hz}, 1 \mathrm{H}), 2.43(\mathrm{~s}, 3 \mathrm{H}) ;{ }^{13} \mathrm{C} \mathrm{NMR}(150 \mathrm{MHz}) \delta 143.8(+), 135.5(-), 135.3(+), 132.1(+)$, $125.4(-), 123.4(-), 18.1(-)$. 
2-Azido-4-chloroaminobenzene ${ }^{78}(150)$.

To a solution of $\mathbf{1 8 5}(5.50 \mathrm{~g}, 18.2 \mathrm{mmol})$ dissolved in methanol $(35 \mathrm{~mL})$ was added hydrazine hydrate $(85 \%$ aqueous solution, $1.1 \mathrm{~mL})$. The reaction proceeded at ambient temperature with occasional stirring for 30 minutes. The resulting paste was added to an aqueous $\mathrm{NaOH}$ solution $(0.25 \mathrm{M}, 330 \mathrm{~mL})$. The insoluble solid was removed by filtration and added to ethanol $(150 \mathrm{~mL})$ with stirring. The insoluble solid was removed by filtration and the filtrate was added to $\mathrm{H}_{2} \mathrm{O}(500 \mathrm{~mL})$. The resulting solid was removed by filtration to give $\mathbf{1 5 0}$ $(1.90 \mathrm{~g}, 11.3 \mathrm{mmol}, 62 \%)$ as an off-white solid.

\section{5-Chloro-2-isopropylbenzimidazole ${ }^{79}$ (151).}

To a refluxing solution of 2-azido-5-chloroaminobenzene (186) (300 mg, $1.8 \mathrm{mmol})$ dissolved in ethanol (absolute, $50 \mathrm{~mL}$ ) was added dropwise a solution of 2-methylpropanal (55) $(0.195 \mathrm{~mL}, 2.2 \mathrm{mmol})$ dissolved in ethanol (absolute, $20 \mathrm{~mL}$ ). The reaction was stirred at reflux for $24 \mathrm{~h}$, then concentrated. The crude solid was purified by column chromatography (hexanes/EtOAc, 8:2, 7:3, 1:1 and 3:7) to give 151 (262 $\mathrm{mg}, 1.4 \mathrm{mmol}, 76 \%$ ) as a brown solid: ${ }^{1} \mathrm{H}$ NMR $\delta 7.51(\mathrm{~d}, J=1.7 \mathrm{~Hz}, 1 \mathrm{H}), 7.43(\mathrm{~d}, J=8.7 \mathrm{~Hz}, 1 \mathrm{H}), 7.18(\mathrm{dd}, J=8.7$ and $2.0 \mathrm{~Hz}, 1 \mathrm{H})$, 3.28 (septet, $J=6.9 \mathrm{~Hz}, 1 \mathrm{H}), 1.46(\mathrm{~d}, J=6.9 \mathrm{~Hz}, 6 \mathrm{H}) ;{ }^{13} \mathrm{C}$ NMR $\delta 161.2,127.8,122.7,114.5$ (broad signal), 29.1, 21.5 (Note: three carbons were not observed due to the slow exchange of the $\mathrm{N}-\mathrm{H}$ proton, which causes these signals to be broadened).

Alternate procedure A for compound 151. Compound 151 was also prepared according to the method above except that a mixture of 2-azido-4-chloroaminobenzene (150) (174 mg, $1.0 \mathrm{mmol})$, ethanol (absolute, $70 \mathrm{~mL}$ total) and 2-methylpropanal (55) $(0.115 \mathrm{~mL}, 1.3$ 
mmol) after $24 \mathrm{~h}$ and chromatography (hexanes/EtOAc, 9:1, 8:2, 7:3, 1:1 and 3:7) gave 151 (132 $\mathrm{mg}, 0.68 \mathrm{mmol}, 66 \%$ ) as a brown solid.

Alternate procedure B for compound 151. 2-azido-4-chloroaminobenzene (150) (405 mg, $2.4 \mathrm{mmol})$, ethanol (absolute, $20 \mathrm{~mL}$ total) and 2-methylpropanal (55) (0.600 mL, $6.6 \mathrm{mmol})$ were reacted as described above with the following change: Glacial acetic acid $(0.5 \mathrm{~mL})$ was added to the azide solution before heating to reflux. After $24 \mathrm{~h}$ and chromatography (hexanes/EtOAc, 9:1, 8:2, 7:3, 1:1 and 3:7), 151 (287 mg, $1.5 \mathrm{mmol}, 61 \%$ ) was isolated as a brown solid.

\section{2-Azido-4-methylaminobenzene ${ }^{78}$ (152).}

To a solution of $194(9.50 \mathrm{~g}, 34.1 \mathrm{mmol})$ dissolved in THF (200 mL) and ethanol (35 $\mathrm{mL})$ was added hydrazine hydrate $(85 \%$ aqueous solution, $14 \mathrm{~mL})$. The reaction stirred at ambient temperature for $20 \mathrm{~h}$. The insoluble solid was removed by filtration and washed with cold ethanol. The filtrate was added to $\mathrm{H}_{2} \mathrm{O}\left(0^{\circ} \mathrm{C}, 700 \mathrm{~mL}\right)$ and extracted with diethyl ether $(6 \mathrm{X}$ $150 \mathrm{~mL})$. The organic phase was dried $\left(\mathrm{MgSO}_{4}\right)$, filtered and concentrated to give 152 (4.90 g, $33.3 \mathrm{mmol}, 98 \%$ ) as an off-white solid.

\section{(Z)-4-(2-Azido-4-methylphenylamino)-3-buten-2-one (153).}

The same procedure as described for 95 was repeated except that a mixture of 2-azido-4methylaminobenzene (152) (600 mg, $4.1 \mathrm{mmol}),(E)-4$-methoxy-3-buten-2-one ${ }^{26}$ (94) (0.5 mL, $4.9 \mathrm{mmol})$, p-toluenesulfonic acid $(10 \mathrm{mg})$ and $\mathrm{CH}_{2} \mathrm{Cl}_{2}$ (anhydrous, $25 \mathrm{~mL}$ ) reacted at ambient temperature for $72 \mathrm{~h}$. Purification by flash chromatography (hexanes/EtOAc, 9:1) gave 153 (684 mg, $3.2 \mathrm{mmol}, 78 \%$ ) as an orange solid: $\mathrm{mp} 66-68{ }^{\circ} \mathrm{C} ;{ }^{1} \mathrm{H}$ NMR $(600 \mathrm{MHz}) \delta 11.65(\mathrm{~d}, J=11.4$ 
$\mathrm{Hz}, 1 \mathrm{H}), 7.15$ (dd, $J=12.6$ and $7.8 \mathrm{~Hz}, 1 \mathrm{H}), 6.98(\mathrm{~d}, J=8.4 \mathrm{~Hz}, 1 \mathrm{H}), 6.91(\mathrm{~s}, 1 \mathrm{H}), 6.89$ (d, $J=$ $8.4 \mathrm{~Hz}, 1 \mathrm{H}), 5.31(\mathrm{~d}, J=7.2 \mathrm{~Hz}, 1 \mathrm{H}), 2.31(\mathrm{~s}, 3 \mathrm{H}), 2.16(\mathrm{~s}, 3 \mathrm{H}) ;{ }^{13} \mathrm{C} \mathrm{NMR}(150 \mathrm{MHz}) \delta 198.7$ (+), $141.6(-), 133.4(+), 129.4(+), 127.6(+), 126.2(-), 119.1(-), 113.4(-), 97.8(-), 29.4(-)$, 20.7 (-); IR (neat) 2115, 1641, 1601, 1559, 1471, $1280 \mathrm{~cm}^{-1}$.

\section{2-Acetyl-1,4-dihydro-7-methylquinoxaline (154).}

Compound 153 (200 mg, $0.9 \mathrm{mmol}$ ), Pd(dba) 2 (32 mg, $0.06 \mathrm{mmol}$ ), dppp (46 mg, 0.1 $\mathrm{mmol})$ and DMF ( $5 \mathrm{~mL}$ ) were combined and reacted at ambient temperature for 3 days. The reaction mixture was then concentrated under high vacuum. Purification by flash chromatography (hexanes/EtOAc, 9:1, 8:2, 7:3, 1:1 and 3:7) gave 154 (31 mg, $0.16 \mathrm{mmol}, 18 \%$ ) as an off-white solid: ${ }^{1} \mathrm{H}$ NMR $\delta 8.34(\mathrm{~s}, 1 \mathrm{H}), 7.10(\mathrm{~d}, J=7.9 \mathrm{~Hz}, 1 \mathrm{H}), 7.02(\mathrm{~s}, 1 \mathrm{H}), 6.83(\mathrm{~d}, J$ $=8.2 \mathrm{~Hz}, 1 \mathrm{H}), 4.38(\mathrm{br} \mathrm{s}, 2 \mathrm{H}), 2.76(\mathrm{~s}, 3 \mathrm{H}), 2.30(\mathrm{~s}, 3 \mathrm{H}) ;{ }^{13} \mathrm{C} \mathrm{NMR}(150 \mathrm{MHz}) \delta 192.6(+)$, $147.7(+), 138.2(+), 131.5(-), 128.3(+), 125.9(-), 124.6(-), 122.3(+), 118.0(-), 27.2(-), 20.1$ (-); IR (neat) 1687, 1632, 1519, 1242, $1030 \mathrm{~cm}^{-1}$.

\section{2-Isopropylbenzimidazole ${ }^{69}$ (158).}

To a solution of 2-nitrosoaminobenzene ${ }^{38}$ (157) (100 mg, $0.8 \mathrm{mmol}$ ) dissolved in DMF (5 $\mathrm{mL})$ in a threaded pressure tube fitted with a Teflon cap was added 2-methylpropanal (55) (0.15 $\mathrm{mL}, 1.7 \mathrm{mmol}$ ). The reaction stirred at $80{ }^{\circ} \mathrm{C}$ for $72 \mathrm{~h}$ and the solvent was removed under high vacuum. Purification by flash chromatography (hexanes/EtOAc, 9:1, 8:2, 1:1, 3:7 and EtOAc) gave 158 (21 mg, $0.131 \mathrm{mmol}, 16 \%)$. 
4-Chloro-2-phthalamidonitrobenzene ${ }^{80}$ (180).

The method of Hall et $a l^{54}$ was employed to transform 5-chloro-2-nitroaminobenzene (65) (17.50 g, $101.6 \mathrm{mmol})$ and phthalic anhydride (179) (15.10 g, $101.8 \mathrm{mmol})$ into 180 (10.00 g, $33.1 \mathrm{mmol}, 33 \%$ ) as a yellow solid: ${ }^{1} \mathrm{H}$ NMR $\delta 8.17(\mathrm{~d}, J=8.6 \mathrm{~Hz}, 1 \mathrm{H}), 8.02-7.95(\mathrm{~m}, 2 \mathrm{H})$, 7.88-7.81 (m, $2 \mathrm{H}), 7.60(\mathrm{dd}, J=8.9$ and $2.5 \mathrm{~Hz}, 1 \mathrm{H}), 7.55(\mathrm{~d}, J=2.2 \mathrm{~Hz}, 1 \mathrm{H}) ;{ }^{13} \mathrm{C}$ NMR $(150$ $\mathrm{MHz}) \delta 165.9(+), 143.9,140.2(+), 134.9(-), 131.6(+), 130.9(-), 129.7(-), 126.9(-), 126.8(+)$, $124.3(-)$

\section{5-Chloro-2-phthalamidonitrobenzene ${ }^{80}$ (181).}

The same procedure as described for $\mathbf{1 8 0}$ was repeated except that a mixture of 4-chloro2-nitroaminobenzene (63) (17.50 g, $101.4 \mathrm{mmol})$ and phthalic anhydride (179) (14.90 g, 100.6 mmol) gave 181 (9.27 g, $30.6 \mathrm{mmol}, 30 \%)$ as a yellow solid: ${ }^{1} \mathrm{H}$ NMR $\delta 8.19(\mathrm{~d}, J=2.5 \mathrm{~Hz}, 1$ H), 8.02-7.94 (m, $2 \mathrm{H}), 7.88-7.81(\mathrm{~m}, 2 \mathrm{H}), 7.76(\mathrm{dd}, J=8.4$ and $2.5 \mathrm{~Hz}, 1 \mathrm{H}), 7.50(\mathrm{~d}, J=8.6$ $\mathrm{Hz}, 1 \mathrm{H}) ;{ }^{13} \mathrm{C}$ NMR $(150 \mathrm{MHz}) \delta 166.0,145.8,135.5,134.9,134.1,131.8,131.7,126.0,124.3$, 124.1.

\section{4-Chloro-2-phthalamidoaminobenzene ${ }^{80}$ (182).}

The reduction of $\mathbf{1 8 0}$ was performed according to the method of Hall et al. ${ }^{54}$ The mixture of 180 (7.60 g, $25.1 \mathrm{mmol})$, iron powder (18.00 g, $322.5 \mathrm{mmol})$, acetone (200 mL) and acetic $\mathrm{acid} / \mathrm{H}_{2} \mathrm{O}(1: 1,40 \mathrm{~mL})$ reacting at reflux with stirring for $2.5 \mathrm{~h}$ gave $182(6.28 \mathrm{~g}, 23.0 \mathrm{mmol}$, 92\%) as a yellow solid: ${ }^{1} \mathrm{H}$ NMR $\delta$ 7.98-7.95 (m, $\left.2 \mathrm{H}\right), 7.83-7.79(\mathrm{~m}, 2 \mathrm{H}), 7.22(\mathrm{dd}, J=8.6$ and $2.2 \mathrm{~Hz}, 1 \mathrm{H}), 7.14(\mathrm{~d}, J=2.5 \mathrm{~Hz}, 1 \mathrm{H}), 6.83(\mathrm{~d}, J=8.4 \mathrm{~Hz}, 1 \mathrm{H}), 3.76(\mathrm{br} \mathrm{s}, 2 \mathrm{H}) ;{ }^{13} \mathrm{C} \mathrm{NMR}(150$ 
MHz) $\delta 166.9,142.1,134.6,131.8,130.1,129.0,124.0,123.5,118.7$ (Note: one carbon is not seen, possibly due to two overlapping signals).

\section{5-Chloro-2-phthalamidoaminobenzene ${ }^{80}$ (183).}

The same procedure as described for $\mathbf{1 8 2}$ was repeated except that a mixture of $\mathbf{1 8 1}(9.00$ g, $29.7 \mathrm{mmol})$, iron powder $(21.00 \mathrm{~g}, 376 \mathrm{mmol})$, acetone $(250 \mathrm{~mL})$ and acetic acid/ $\mathrm{H}_{2} \mathrm{O}(1: 1,50$ $\mathrm{mL})$ after $15 \mathrm{~h}$ gave $183(6.75 \mathrm{~g}, 24.8 \mathrm{mmol}, 83 \%)$ as a yellow solid: ${ }^{1} \mathrm{H} \mathrm{NMR}(600 \mathrm{MHz}) \delta$ 7.96-7.94 (m, 2 H), 7.81-7.79 (m, 2 H), 7.03 (d, $J=7.8 \mathrm{~Hz}, 1 \mathrm{H}), 6.88$ (s, $1 \mathrm{H}), 6.86(\mathrm{~d}, J=8.4$ $\mathrm{Hz}, 1 \mathrm{H}), 3.83($ br s, $2 \mathrm{H}) ;{ }^{13} \mathrm{C}$ NMR (150 MHz) $\delta 167.1(+), 144.4(+), 135.7(+), 134.6(-)$, $131.9(+), 130.3(-), 123.9(-), 119.3(-), 117.4(-), 116.4(+)$.

\section{4-Chloro-2-phthalamidophenylazide ${ }^{80}$ (184).}

The same procedure as described for $\mathbf{1 3 1}$ was repeated except that a mixture of $\mathbf{1 8 2}$ (6.25 g, $22.9 \mathrm{mmol}), \mathrm{H}_{2} \mathrm{O}(150 \mathrm{~mL}), \mathrm{HCl}$ (concentrated, $\left.25 \mathrm{~mL}\right), \mathrm{NaNO}_{2}(1.60 \mathrm{~g}, 23.2 \mathrm{mmol})$ and $\mathrm{NaN}_{3}$ (1.50 g, $23.1 \mathrm{mmol})$ gave $184(5.10 \mathrm{~g}, 17.2 \mathrm{mmol}, 75 \%)$ as an off-white solid: ${ }^{1} \mathrm{H}$ NMR $\delta 8.00$ $7.93(\mathrm{~m}, 2 \mathrm{H}), 7.85-7.78$ (m, $2 \mathrm{H}), 7.49$ (dd, $J=8.7$ and $2.5 \mathrm{~Hz}, 1 \mathrm{H}), 7.32(\mathrm{~d}, J=2.2 \mathrm{~Hz}, 1 \mathrm{H})$, $7.25(\mathrm{~d}, J=8.7 \mathrm{~Hz}, 1 \mathrm{H})$.

\section{5-Chloro-2-phthalamidophenylazide ${ }^{80}$ (185).}

The same procedure as described for $\mathbf{1 3 1}$ was repeated except that a mixture of $\mathbf{1 8 3}$ (6.75 g, $24.8 \mathrm{mmol}), \mathrm{H}_{2} \mathrm{O}(100 \mathrm{~mL}), \mathrm{HCl}$ (concentrated, $\left.25 \mathrm{~mL}\right), \mathrm{NaNO}_{2}(1.80 \mathrm{~g}, 26.1 \mathrm{mmol})$ and $\mathrm{NaN}_{3}(1.70 \mathrm{~g}, 26.3 \mathrm{mmol})$ gave 185 (4.40 g, $\left.14.6 \mathrm{mmol}, 59 \%\right)$ as an off-white solid: ${ }^{1} \mathrm{H}$ NMR $\delta$ 
7.99-7.92 (m, $2 \mathrm{H}), 7.84-7.77$ (m, $2 \mathrm{H}), 7.30(\mathrm{~d}, J=2.0 \mathrm{~Hz}, 1 \mathrm{H}), 7.26-7.23(\mathrm{~m}, 2 \mathrm{H}) ;{ }^{13} \mathrm{C} \mathrm{NMR}$ (150 MHz) $\delta 166.6,139.1,136.3,134.5,131.8,131.5,125.6,123.9,121.2,119.6$.

\section{2-Azido-5-chloroaminobenzene ${ }^{80}$ (186).}

The same procedure as described for $\mathbf{1 5 0}$ was repeated except that a mixture of $\mathbf{1 8 4}$ (5.10 g, $16.9 \mathrm{mmol})$, methanol $(35 \mathrm{~mL})$, hydrazine hydrate $(85 \%$ aqueous solution, $1.2 \mathrm{~mL})$ and $\mathrm{NaOH}$ $(0.25 \mathrm{M}, 220 \mathrm{~mL})$ gave $186(1.50 \mathrm{~g}, 9.1 \mathrm{mmol}, 54 \%)$ as an off-white solid: ${ }^{1} \mathrm{H}$ NMR $\delta 6.93(\mathrm{~d}, J$ $=8.4 \mathrm{~Hz}, 1 \mathrm{H}), 6.74(\mathrm{dd}, J=8.4$ and $2.2 \mathrm{~Hz}, 1 \mathrm{H}), 6.67(\mathrm{~d}, J=2.2 \mathrm{~Hz}, 1 \mathrm{H}), 3.88(\mathrm{br} \mathrm{s}, 2 \mathrm{H}) ;{ }^{13} \mathrm{C}$ NMR (150 MHz) $\delta 139.1,130.7,123.8,119.2,118.7,115.4$.

\section{5-Methyl-2-phthalamidonitrobenzene ${ }^{81}$ (188).}

To a refluxing solution of phthaloyl chloride (187) $(15 \mathrm{~mL}, 104 \mathrm{mmol})$ dissolved in toluene $(100 \mathrm{~mL})$ was added dropwise a solution of 4-methyl-2-nitroaminobenzene (59) (15.00 g, $98.6 \mathrm{mmol})$, pyridine $(20.0 \mathrm{~mL}, 247 \mathrm{mmol})$ and toluene $(100 \mathrm{~mL})$. The reaction was stirred at reflux for $20 \mathrm{~h}$. The solution was filtered while hot through an oven-heated fritted funnel and the filtrate was concentrated. The product was purified by recrystallization from acetic acid to give $188(26.60 \mathrm{~g}, 94.2 \mathrm{mmol}, 96 \%)$ as a yellow solid: ${ }^{1} \mathrm{H}$ NMR $\delta 8.02(\mathrm{~d}, J=1.2 \mathrm{~Hz}, 1 \mathrm{H}), 8.00-$ $7.78(\mathrm{~m}, 2 \mathrm{H}), 7.85-7.78(\mathrm{~m}, 2 \mathrm{H}), 7.59(\mathrm{dd}, J=8.2$ and $1.2 \mathrm{~Hz}, 1 \mathrm{H}), 7.40(\mathrm{~d}, J=8.2 \mathrm{~Hz}, 1 \mathrm{H})$; ${ }^{13} \mathrm{C}$ NMR (150 MHz) $\delta 166.4(+), 145.2(+), 140.6(+), 134.7(-), 134.6(-), 131.7(+), 130.5(-)$, $126.0(-), 123.9(-), 122.8(+), 21.0(-)$. 
3-Methyl-2-phthalamidonitrobenzene ${ }^{82}$ (189).

The same procedure as described for 188 was repeated except that a mixture of phthaloyl chloride (187) (1.5 mL, $10.4 \mathrm{mmol}), 6$-methyl-2-nitroaminobenzene (67) (1.50 g, 9.9 mmol), pyridine $(2.0 \mathrm{~mL}, 24.7 \mathrm{mmol})$ and toluene $(100 \mathrm{~mL}$ total $)$ was reacted for $40 \mathrm{~h}$. Recrystallization from acetic acid gave $189(2.45 \mathrm{~g}, 8.7 \mathrm{mmol}, 88 \%)$ as a yellow solid.

\section{3-Nitro-2-phthalamidopyridine (190).}

The same procedure as described for $\mathbf{1 8 8}$ was repeated except that a mixture of phthaloyl chloride (187) (4.0 mL, 27.7 mmol), 2-amino-3-nitropyridine (86) (3.00 g, 21.6 mmol), pyridine $(6.0 \mathrm{~mL}, 74.2 \mathrm{mmol})$ and toluene $(100 \mathrm{~mL}$ total) was reacted for $42 \mathrm{~h}$. Recrystallization from acetic acid gave 190 (5.56 g, $20.7 \mathrm{mmol}, 96 \%)$ as a yellow solid: $\mathrm{mp} 171-173^{\circ} \mathrm{C} ;{ }^{1} \mathrm{H}$ NMR $\delta$ $8.94(\mathrm{dd}, J=4.9$ and $1.7 \mathrm{~Hz}, 1 \mathrm{H}), 8.56(\mathrm{dd}, J=8.2$ and $1.5 \mathrm{~Hz}, 1 \mathrm{H}), 8.03-7.98(\mathrm{~m}, 2 \mathrm{H})$, 7.90$7.80(\mathrm{~m}, 2 \mathrm{H}), 7.65(\mathrm{dd}, J=8.2$ and $4.7 \mathrm{~Hz}, 1 \mathrm{H}) ;{ }^{13} \mathrm{C}$ NMR $\delta 165.5(+), 153.3(-), 142.5(+)$, $139.1(+), 134.9(-), 134.5(-), 131.7(+), 124.6(-), 124.3(-)$; IR (neat) 1786, 1735, 1592, 1541, $1355 \mathrm{~cm}^{-1}$.

\section{5-Methyl-2-phthalamidoaminobenzene ${ }^{83}$ (191).}

Compound 188 (26.30 g, $93.2 \mathrm{mmol}), 10 \% \mathrm{Pd} / \mathrm{C}$ (4.60 g, $4.3 \mathrm{mmol} \mathrm{Pd}$ ) and ethanol (absolute, $225 \mathrm{~mL}$ ) were combined in a threaded pressure tube fitted with a teflon cap attached to a hydrogenation apparatus. The tube was flushed 3 times with $\mathrm{H}_{2}$. The reaction was stirred at ambient temperature under $\mathrm{H}_{2}$ (4 atm) for $15 \mathrm{~h}$. After releasing the pressure, the open flask was heated gently to dissolve the solid product. The hot solution was filtered through an oven-heated fritted funnel packed with Celite and washed with boiling ethyl acetate. The filtrate was 
concentrated and the product was purified by recrystallization from ethanol to give 191 (20.60 g, $81.7 \mathrm{mmol}, 88 \%$ ) as a yellow solid: ${ }^{1} \mathrm{H}$ NMR $\delta$ 7.97-7.91 (m, $\left.2 \mathrm{H}\right), 7.82-7.75(\mathrm{~m}, 2 \mathrm{H}), 7.00(\mathrm{~d}$, $J=8.6 \mathrm{~Hz}, 1 \mathrm{H}), 6.74-6.71$ (m, $2 \mathrm{H}), 3.67$ (br s, $2 \mathrm{H}), 2.32$ (s, $3 \mathrm{H}) ;{ }^{13} \mathrm{C}$ NMR (150 MHZ) $\delta$ 167.4, 143.0, 140.3, 134.3, 132.0, 128.8, 123.7, 120.2, 118.3, 115.3, 21.2.

\section{3-Methyl-2-phthalamidoaminobenzene ${ }^{82}$ (192).}

The same procedure as described for $\mathbf{1 9 1}$ was repeated except that a mixture of $\mathbf{1 8 9}$ ( 2.30 g, $8.2 \mathrm{mmol}), 10 \% \mathrm{Pd} / \mathrm{C}(500 \mathrm{mg}, 0.47 \mathrm{mmol} \mathrm{Pd}$ ), ethanol (absolute, $100 \mathrm{~mL})$ and $\mathrm{H}_{2}(3 \mathrm{~atm})$ after $44 \mathrm{~h}$ at $60^{\circ} \mathrm{C}$ gave $192(1.50 \mathrm{~g}, 6.1 \mathrm{mmol}, 75 \%)$ as a yellow solid.

\section{3-Amino-2-phthalamidopyridine (193).}

The same procedure as described for $\mathbf{1 9 1}$ was repeated except that a mixture of 190 (3.50 g, $12.9 \mathrm{mmol}), 10 \% \mathrm{Pd} / \mathrm{C}(700 \mathrm{mg}, 0.66 \mathrm{mmol} \mathrm{Pd})$, ethanol (absolute, $50 \mathrm{~mL})$ and $\mathrm{H}_{2}(4 \mathrm{~atm})$ after $25 \mathrm{~h}$ at $60{ }^{\circ} \mathrm{C}$ gave $193(1.50 \mathrm{~g}, 6.4 \mathrm{mmol}, 50 \%)$ as a yellow solid: $\mathrm{mp} 204-206{ }^{\circ} \mathrm{C} ;{ }^{1} \mathrm{H}$ NMR $\delta 8.10(\mathrm{t}, J=3.0 \mathrm{~Hz}, 1 \mathrm{H}), 8.00-7.93(\mathrm{~m}, 2 \mathrm{H}), 7.83-7.77(\mathrm{~m}, 2 \mathrm{H}), 7.23(\mathrm{~d}, J=3.2 \mathrm{~Hz}, 2$ H), 3.85 (br s, 2 H); ${ }^{13} \mathrm{C}$ NMR $\delta 166.9(+), 140.0(+), 139.8(-), 134.5(-), 132.8(+), 132.1(+)$, 125.5 (-), 125.3 (-), 124.0 (-); IR (neat) 3434, 1716, 1469, $1377 \mathrm{~cm}^{-1}$; HRMS (EI) calc. for $\mathrm{C}_{13} \mathrm{H}_{9} \mathrm{~N}_{3} \mathrm{O}_{2} 239.0695$, found 239.0703.

\section{5-Methyl-2-phthalamidophenylazide (194).}

The same procedure as described for $\mathbf{1 3 1}$ was repeated except that a mixture of $\mathbf{1 9 1}$ (10.00 g, $39.7 \mathrm{mmol}), \mathrm{H}_{2} \mathrm{O}(300 \mathrm{~mL}), \mathrm{HCl}$ (concentrated, $\left.75 \mathrm{~mL}\right), \mathrm{NaNO}_{2}(3.30 \mathrm{~g}, 47.8 \mathrm{mmol})$ and $\mathrm{NaN}_{3}(3.10 \mathrm{~g}, 47.7 \mathrm{mmol})$ gave $194(9.90 \mathrm{~g}, 35.5 \mathrm{mmol}, 90 \%)$ as an off-white solid: $\mathrm{mp}$ 


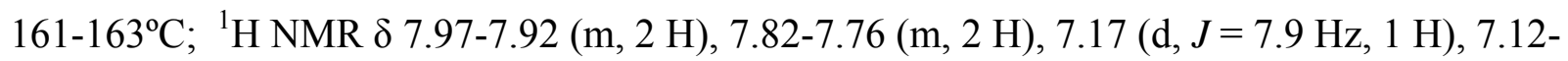
7.07 (m, $2 \mathrm{H}), 2.44(\mathrm{~s}, 3 \mathrm{H}) ;{ }^{13} \mathrm{C}$ NMR $\delta 166.9(+), 141.1(+), 137.1(+), 134.1(-), 131.8(+)$, $130.0(-), 126.1(-), 123.6(-), 119.8(+), 119.6(-), 21.2(-)$; IR (neat) 2110, 1734, 1714, 1514, $1383 \mathrm{~cm}^{-1}$.

\section{3-Methyl-2-phthalamidophenylazide (195).}

The same procedure as described for $\mathbf{1 3 1}$ was repeated except that a mixture of $\mathbf{1 9 2}$ (1.37 g, $5.4 \mathrm{mmol}), \mathrm{H}_{2} \mathrm{O}(100 \mathrm{~mL}), \mathrm{HCl}$ (concentrated, $\left.25 \mathrm{~mL}\right), \mathrm{NaNO}_{2}(450 \mathrm{mg}, 6.5 \mathrm{mmol})$ and $\mathrm{NaN}_{3}$

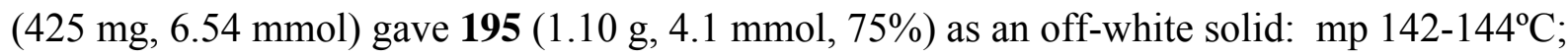
${ }^{1} \mathrm{H}$ NMR $\delta$ 7.99-7.94 (m, 2 H), 7.83-7.78 (m, $\left.2 \mathrm{H}\right), 7.41$ (t, $\left.J=7.4 \mathrm{~Hz}, 1 \mathrm{H}\right), 7.16-7.13$ (m, $\left.2 \mathrm{H}\right)$, $2.21(\mathrm{~s}, 3 \mathrm{H}) ;{ }^{13} \mathrm{C}$ NMR $\delta 166.9(+), 139.4(+), 138.2(+), 134.3(-), 132.0(+), 130.4(-), 126.9$ (-), $123.8(-), 121.7(+), 116.6(-), 17.9(-)$; IR (neat) 2361, 2124, 1742, 1717, 1469, $1374 \mathrm{~cm}^{-1}$; HRMS (EI) calc. for $\mathrm{C}_{15} \mathrm{H}_{10} \mathrm{~N}_{4} \mathrm{O}_{2} 278.0804$, found 278.0801.

\section{3-Azido-2-phthalamidopyridine (196).}

The same procedure as described for $\mathbf{1 3 1}$ was repeated except that a mixture of $\mathbf{1 9 3}$ (1.50 g, $6.1 \mathrm{mmol}), \mathrm{H}_{2} \mathrm{O}(60 \mathrm{~mL}), \mathrm{HCl}$ (concentrated, $\left.15 \mathrm{~mL}\right), \mathrm{NaNO}_{2}(500 \mathrm{mg}, 7.3 \mathrm{mmol})$ and $\mathrm{NaN}_{3}$ (485 mg, $7.5 \mathrm{mmol}$ ) gave 196 (970 mg, $3.7 \mathrm{mmol}, 60 \%$ ) as an off-white solid: $\mathrm{mp} 167-169^{\circ} \mathrm{C}$; ${ }^{1} \mathrm{H}$ NMR $\delta 8.47$ (dd, $J=1.5$ and $\left.4.7 \mathrm{~Hz}, 1 \mathrm{H}\right), 8.00-7.94$ (m, $\left.2 \mathrm{H}\right), 7.85-7.78$ (m, $\left.2 \mathrm{H}\right), 7.68$ (dd, $J$ $=8.2$ and $1.5 \mathrm{~Hz}, 1 \mathrm{H}), 7.50(\mathrm{dd}, J=8.2$ and $4.7 \mathrm{~Hz}, 1 \mathrm{H}) ;{ }^{13} \mathrm{C} \mathrm{NMR} \delta 166.3,145.6(-), 137.2$, 135.3, $134.5(-), 132.0(+), 127.9(-), 125.6(-), 124.0(-)$; IR (neat) 2126, 1723, 1455, $1374 \mathrm{~cm}^{-1}$. 
2-Azido-6-methylaminobenzene ${ }^{84}$ (197).

The same procedure as described for 152 was repeated except that a mixture of $195(1.10$ g, $3.9 \mathrm{mmol})$, THF (50 mL), ethanol $(10 \mathrm{~mL})$ and hydrazine hydrate (85\% aqueous solution, 1.5 $\mathrm{mL}$ ) was reacted at ambient temperature for $48 \mathrm{~h}$. The product was purified by column chromatography (hexanes/EtOAc, 8:2) to give 197 (343 mg, $2.3 \mathrm{mmol}, 60 \%$ ) as an off-white solid: ${ }^{1} \mathrm{H}$ NMR $\delta 6.93(\mathrm{~d}, J=8.7 \mathrm{~Hz}, 1 \mathrm{H}), 6.86(\mathrm{~d}, J=7.6 \mathrm{~Hz}, 1 \mathrm{H}), 6.72(\mathrm{t}, J=7.7 \mathrm{~Hz}, 1 \mathrm{H})$, 3.76 (br s, $2 \mathrm{H}), 2.16$ (s, $3 \mathrm{H}) ;{ }^{13} \mathrm{C}$ NMR $(150 \mathrm{MHz}) \delta 136.3,126.7,124.8,123.4,118.4,115.9$, 17.3.

\section{2-Amino-3-azidopyridine (198).}

The same procedure as described for 152 was repeated except that a mixture of 196 (840 $\mathrm{mg}, 3.2 \mathrm{mmol})$, THF (20 mL), ethanol ( $5 \mathrm{~mL})$ and hydrazine hydrate ( $85 \%$ aqueous solution, 1.5 $\mathrm{mL}$ ) was reacted at ambient temperature for $26 \mathrm{~h}$. The insoluble solid was removed by filtration and the filtrate was condensed. The resulting solid was added to $\mathrm{HCl}(10 \%, 100 \mathrm{~mL})$ and the insoluble solid was removed by filtration. The filtrate was washed with diethyl ether ( 3 X 50 $\mathrm{mL}$ ). The aqueous layer was made basic with $\mathrm{NaOH}(3 \mathrm{M})$ and was then extracted with diethyl ether (4 X $50 \mathrm{~mL})$. The combined organic phase was dried $\left(\mathrm{MgSO}_{4}\right)$, filtered and concentrated to give 198 (412 mg, $3.1 \mathrm{mmol}, 96 \%$ ) as a brown solid: $\mathrm{mp} 71-73^{\circ} \mathrm{C} ;{ }^{1} \mathrm{H}$ NMR $\delta 7.86(\mathrm{dd}, J=$ 4.9 and $1.5 \mathrm{~Hz}, 1 \mathrm{H}), 7.23(\mathrm{dd}, J=7.7$ and $1.5 \mathrm{~Hz}, 1 \mathrm{H}), 6.70(\mathrm{dd}, J=7.7$ and $4.9 \mathrm{~Hz}, 1 \mathrm{H}), 4.74$

(br s, 2 H); ${ }^{13}$ C NMR $\delta 150.9(+), 143.4(-), 124.5(-), 120.3(+), 113.4(-)$; IR (neat) 3453, 2120, 1629, 1487, $1257 \mathrm{~cm}^{-1}$; HRMS (EI) calc. for $\mathrm{C}_{5} \mathrm{H}_{5} \mathrm{~N}_{5}$ 135.0545, found 135.0542 . 


\section{5-Chloro-2-hexylbenzimidazole (199).}

The same procedure as described for $\mathbf{1 5 1}$ was repeated except that a mixture of 2-azido5-chloroaminobenzene (186) (302 mg, $1.8 \mathrm{mmol}$ ), ethanol (absolute, $70 \mathrm{~mL}$ total) and heptanal (83) $(0.290 \mathrm{~mL}, 2.2 \mathrm{mmol})$ after $24 \mathrm{~h}$ and chromatography (hexanes/EtOAc, 9:1, 8:2 and 7:3) gave 199 (266 mg, $1.1 \mathrm{mmol}, 63 \%$ ) as a brown solid: $\mathrm{mp} 120-122{ }^{\circ} \mathrm{C} ;{ }^{1} \mathrm{H}$ NMR $\delta 12.01$ (br s, 1 H), $7.53(\mathrm{~d}, J=2.0 \mathrm{~Hz}, 1 \mathrm{H}), 7.45(\mathrm{~d}, J=8.4 \mathrm{~Hz}, 1 \mathrm{H}), 7.19(\mathrm{dd}, J=8.6$ and $2.0 \mathrm{~Hz}, 1 \mathrm{H}), 2.97$ (t, $J=7.6 \mathrm{~Hz}, 2 \mathrm{H}), 1.85$ (pentet, $J=7.4 \mathrm{~Hz}, 2 \mathrm{H}), 1.40-1.10$ (m, $6 \mathrm{H}), 0.79$ (t, $J=6.9 \mathrm{~Hz}, 3 \mathrm{H}$ );

${ }^{13} \mathrm{C}$ NMR $\delta 157.3(+), 139.3(+), 137.0(+), 127.7(+), 122.6(-), 115.1(-), 114.4(-), 31.3(+)$, $29.3(+), 28.9(+), 28.4(+), 22.3(+), 13.8(-)$; IR (neat) 2921, 2360, 1450, $1024 \mathrm{~cm}^{-1}$; HRMS (EI) calc. for $\mathrm{C}_{13} \mathrm{H}_{17} \mathrm{C} 1 \mathrm{~N}_{2} 236.1080$, found 236.1071.

\section{2-Isopropyl-5-methylbenzimidazole ${ }^{85}(200)$.}

The same procedure as described for $\mathbf{1 5 1}$ was repeated except that a mixture of 2-azido4-methylaminobenzene (152) (300 mg, $2.0 \mathrm{mmol}$ ), ethanol (absolute, $70 \mathrm{~mL}$ total) and 2methylpropanal (55) (0.220 mL, $2.4 \mathrm{mmol})$ after $24 \mathrm{~h}$ and chromatography (hexanes/EtOAc, 9:1, 8:2, 7:3, 1:1, 3:7 and EtOAc) gave 200 (249 $\mathrm{mg}, 1.4 \mathrm{mmol}, 71 \%)$ as a brown solid: ${ }^{1} \mathrm{H}$ NMR $\delta$ $7.44(\mathrm{~d}, J=8.2 \mathrm{~Hz}, 1 \mathrm{H}), 7.35(\mathrm{~s}, 1 \mathrm{H}), 7.02(\mathrm{dd}, J=8.2$ and $1.2 \mathrm{~Hz}, 1 \mathrm{H}), 3.33$ (septet, $J=6.9$ $\mathrm{Hz}, 1 \mathrm{H}), 2.43$ (s, $3 \mathrm{H}), 1.48$ (d, $J=6.9 \mathrm{~Hz}, 6 \mathrm{H}) ;{ }^{13} \mathrm{C}$ NMR $\delta 160.0,138.5$ (broad signal), 137.0 (broad signal), 131.8, 123.4, 114.5 (broad signal), 114.0 (broad signal), 29.1, 21.7, 21.6.

\section{2-Hexyl-5-methylbenzimidazole ${ }^{86}(201)$.}

The same procedure as described for $\mathbf{1 5 1}$ was repeated except that a mixture of 2-azido4-methylaminobenzene (152) (305 $\mathrm{mg}, 2.1 \mathrm{mmol}$ ), ethanol (absolute, $70 \mathrm{~mL}$ total) and heptanal 
(83) $(0.330 \mathrm{~mL}, 2.5 \mathrm{mmol})$ after $24 \mathrm{~h}$ and chromatography (hexanes/EtOAc, 8:2, 7:3, 1:1, 3:7 and EtOAc) gave 201 (334 mg, $1.5 \mathrm{mmol}, 75 \%$ ) as a brown solid: ${ }^{1} \mathrm{H}$ NMR $\delta 12.03$ (br s, $1 \mathrm{H}$ ), $7.47(\mathrm{~d}, J=8.2 \mathrm{~Hz}, 1 \mathrm{H}), 7.38(\mathrm{~s}, 1 \mathrm{H}), 7.04(\mathrm{dd}, J=8.2$ and $1.2 \mathrm{~Hz}, 1 \mathrm{H}), 2.99$ (t, $J=7.7 \mathrm{~Hz}, 2$ H), 2.45 (s, $3 \mathrm{H}), 1.87$ (pentet, $J=7.4 \mathrm{~Hz}, 2 \mathrm{H}), 1.38-1.15(\mathrm{~m}, 6 \mathrm{H}), 0.79$ (t, $J=6.7 \mathrm{~Hz}, 3 \mathrm{H})$; ${ }^{13} \mathrm{C}$ NMR $\delta 155.0,131.8,123.5,114.5$ (broad signal), 31.4, 29.3, 29.0, 28.3, 22.5, 21.6, 14.0 (Note: three carbons were not observed due to the slow exchange of the N-H proton, which causes these signals to be broadened).

\section{2-Benzyl-5-methylbenzimidazole ${ }^{87}$ (202) and 5-methylbenzimidazole ${ }^{69}$ (203).}

The same procedure as described for $\mathbf{1 5 1}$ was repeated except that a mixture of 2-azido4-methylaminobenzene (152) (300 mg, $2.0 \mathrm{mmol}$ ), ethanol (absolute, $70 \mathrm{~mL}$ total) and phenylacetaldehyde (81) $(0.280 \mathrm{~mL}, 2.4 \mathrm{mmol})$ after $24 \mathrm{~h}$ and chromatography (hexanes/EtOAc, 8:2, 7:3, 1:1, 3:7 and EtOAc) gave $202(47 \mathrm{mg}, 0.21 \mathrm{mmol}, 10 \%)$ as a brown solid and 203 (107 $\mathrm{mg}, 0.81 \mathrm{mmol}, 40 \%$ ) as an off-white solid.

Alternate procedure for 202 and 203. 2-azido-4-methylaminobenzene (152) (300 mg, $2.0 \mathrm{mmol})$, ethanol (absolute, $70 \mathrm{~mL}$ total) and phenylacetaldehyde $(\mathbf{8 1})(0.300 \mathrm{~mL}, 2.6 \mathrm{mmol})$ were reacted as described for $\mathbf{1 5 1}$ with the following change: Glacial acetic acid $(25 \mu \mathrm{L})$ was added to the azide solution before heating to reflux. After $24 \mathrm{~h}$ and chromatography (hexanes/EtOAc, 9:1, 8:2, 7:3, 1:1, 3:7 and EtOAc), 202 (87 mg, $0.39 \mathrm{mmol}, 19 \%)$ was isolated as a brown solid and 203 (79 $\mathrm{mg}, 0.60 \mathrm{mmol}, 30 \%)$ as an off-white solid.

Alternate procedure for 203. The same procedure as described for 151 was repeated except that a mixture of 2-azido-4-methylaminobenzene (152) (306 mg, $2.1 \mathrm{mmol}$ ), ethanol (absolute, $70 \mathrm{~mL}$ total) and paraformaldehyde $(78 \mathrm{mg}, 2.6 \mathrm{mmol}$ ) after $24 \mathrm{~h}$ and chromatography 
(hexanes/EtOAc, 6:4, 1:1, 3:7 and EtOAc) gave 203 (49 mg, $0.37 \mathrm{mmol}, 18 \%$ ) as an off-white solid.

\section{5-Methyl-2-tert-butylbenzimidazole ${ }^{88}$ (206).}

The same procedure as described for $\mathbf{1 5 1}$ was repeated except that a mixture of 2-azido4-methylaminobenzene (152) (300 mg, $2.0 \mathrm{mmol})$, ethanol (absolute, $70 \mathrm{~mL}$ total) and trimethylacetaldeyde (205) $(0.270 \mathrm{~mL}, 2.5 \mathrm{mmol})$ after $24 \mathrm{~h}$ and chromatography (hexanes/EtOAc, 9:1, 8:2, 7:3, 1:1, 3:7 and EtOAc) gave 206 (94 mg, $0.5 \mathrm{mmol}, 25 \%)$ as a brown solid.

\section{2,5-Dimethylbenzimidazole ${ }^{69}$ (208).}

The same procedure as described for 151 was repeated except that a mixture of 2-azido4-methylaminobenzene (152) (302 mg, $2.0 \mathrm{mmol}$ ), ethanol (absolute, $70 \mathrm{~mL}$ total) and acetaldehyde (207) (0.140 mL, $2.5 \mathrm{mmol})$ after $24 \mathrm{~h}$ and chromatography (hexanes/EtOAc, 9:1, 8:2, 7:3, 1:1, 3:7 and EtOAc) gave $208(99 \mathrm{mg}, 0.7 \mathrm{mmol}, 33 \%)$ as a brown solid.

\section{(E)-5-Methyl-2-(1-propenyl)benzimidazole ${ }^{89}$ (210).}

The same procedure as described for $\mathbf{1 5 1}$ was repeated except that a mixture of 2-azido4-methylaminobenzene (152) (308 mg, $2.1 \mathrm{mmol})$, ethanol (absolute, $70 \mathrm{~mL}$ total) and crotonaldeyde (209) (0.20 mL, $2.4 \mathrm{mmol})$ after $24 \mathrm{~h}$ and chromatography (hexanes/EtOAc, 95:5, 9:1, 8:2, 7:3, 1:1, 3:7 and EtOAc) gave 210 (50 mg, $0.29 \mathrm{mmol}, 14 \%$ ). 
2-Isopropy1-4-methylbenzimidazole ${ }^{70}(136)$ and 4-methylbenzimidazole ${ }^{90}$ (211).

The same procedure as described for 151 was repeated except that a mixture of 2-azido6-methylaminobenzene (197) (280 mg, $1.9 \mathrm{mmol})$, ethanol (absolute, $70 \mathrm{~mL}$ total) and 2methylpropanal (55) $(0.210 \mathrm{~mL}, 2.3 \mathrm{mmol})$ after $24 \mathrm{~h}$ and chromatography (hexanes/EtOAc, 9:1, 8:2, 7:3, 1:1, 3:7 and EtOAc) gave $136(226 \mathrm{mg}, 1.3 \mathrm{mmol}, 69 \%)$ as a brown solid and 211 (21 mg, $0.16 \mathrm{mmol}, 8 \%$ ) as an off-white solid: $211{ }^{1} \mathrm{H}$ NMR $\delta 8.60$ (br s, $\left.1 \mathrm{H}\right), 8.12(\mathrm{~s}, 1 \mathrm{H}), 7.49$ (d, $J=7.9 \mathrm{~Hz}, 1 \mathrm{H}), 7.20(\mathrm{t}, J=7.4 \mathrm{~Hz}, 1 \mathrm{H}), 7.93(\mathrm{~d}, J=7.4 \mathrm{~Hz}, 1 \mathrm{H}), 2.62(\mathrm{~s}, 3 \mathrm{H})$.

Alternate procedure for 136. See page 90.

\section{2-Isopropylimidazo[b]pyridine ${ }^{91}$ (212) and 2,3-diaminopyridine ${ }^{69}$ (213).}

The same procedure as described for 151 was repeated except that a mixture of 2-amino3-azidopyridine (198) (302 mg, $2.2 \mathrm{mmol}$ ), ethanol (absolute, $70 \mathrm{~mL}$ total) and 2-methylpropanal (55) $(0.250 \mathrm{~mL}, 2.8 \mathrm{mmol})$ after $24 \mathrm{~h}$ and chromatography (hexanes/EtOAc, 9:1, 8:2, 7:3, 1:1, 3:7 and EtOAc) gave 212 (27 mg, $0.17 \mathrm{mmol}, 7 \%)$ and $213(81 \mathrm{mg}, 0.74 \mathrm{mmol}, 33 \%)$ as brown solids: $212 \mathrm{mp} 140-142{ }^{\circ} \mathrm{C} ;{ }^{1} \mathrm{H}$ NMR $\delta 8.36(\mathrm{dd}, J=4.9$ and $1.5 \mathrm{~Hz}, 1 \mathrm{H}), 8.07(\mathrm{~d}, J=7.9 \mathrm{~Hz}, 1$ H), $7.25(\mathrm{dd}, J=7.9$ and $4.9 \mathrm{~Hz}, 1 \mathrm{H}), 3.40$ (septet, $J=7.2 \mathrm{~Hz}, 1 \mathrm{H}), 1.58(\mathrm{~d}, J=7.2 \mathrm{~Hz}, 6 \mathrm{H})$; ${ }^{13} \mathrm{C}$ NMR $\delta 162.4(+), 149.2(+), 141.6(-), 136.0(+), 127.1(-), 117.7(-), 29.7(-), 21.3(-) ;$ IR (neat) $2971,2750,1609,1410,1271 \mathrm{~cm}^{-1}$.

\section{2-Cyclopropylmethyl-5-methylbenzimidazole (217).}

A mixture of 2-cyclopropylethanol (216) (300 mg, $3.5 \mathrm{mmol})$ and PCC (980 mg, 4.6 mmol) dissolved in $\mathrm{CH}_{2} \mathrm{Cl}_{2}$ (anhydrous, $50 \mathrm{~mL}$ ) stirred at ambient temperature for $7 \mathrm{~h}$. The solution was then filtered through a fritted funnel packed with a thin layer of silica gel. To the 
filtrate (crude aldehyde) in a threaded pressure vessel fitted with a teflon cap was added 2-azido4-methylaminobenzene (152) $(310 \mathrm{mg}, 2.1 \mathrm{mmol})$. The reaction was stirred at $100{ }^{\circ} \mathrm{C}$ for $24 \mathrm{~h}$ and the mixture was then concentrated. Purification by column chromatography (hexanes/EtOAc, 9:1, 8:2, 7:3, 1:1 and 3:7) gave 217 (73 mg, $0.39 \mathrm{mmol}, 11 \%$ ): $\mathrm{mp} 155-157^{\circ} \mathrm{C}$; ${ }^{1} \mathrm{H}$ NMR $\delta 7.45$ (d, $\left.J=8.2 \mathrm{~Hz}, 1 \mathrm{H}\right), 7.34(\mathrm{~s}, 1 \mathrm{H}), 7.03(\mathrm{~d}, J=8.2 \mathrm{~Hz}, 1 \mathrm{H}), 2.87$ (d, $J=7.2 \mathrm{~Hz}$, $2 \mathrm{H}), 2.44$ (s, $3 \mathrm{H}), 1.29-1.13(\mathrm{~m}, 1 \mathrm{H}), 0.58-0.50(\mathrm{~m}, 2 \mathrm{H}), 0.28-0.22(\mathrm{~m}, 2 \mathrm{H}) ;{ }^{13} \mathrm{C}$ NMR $\delta$ $154.8(+), 138.5(+), 137.0(+), 131.6(+), 123.3(-), 114.4(-), 114.1(-), 34.0(+), 21.5(-), 9.5(-)$, 4.8 (+); IR (neat) $3005,2919,2865,1449,1282 \mathrm{~cm}^{-1}$; HRMS (EI) calc. for $\mathrm{C}_{12} \mathrm{H}_{14} \mathrm{~N}_{2}\left(\mathrm{M}-\mathrm{H}^{+}\right)$ 185.1079, found 185.1078 .

\section{6-Chloro-1,3-dimethyluracil ${ }^{69}$ (218).}

To a solution of 1,3-dimethylbarbituric acid (224) (6.50 g, $41.6 \mathrm{mmol})$ and $\mathrm{H}_{2} \mathrm{O}(2 \mathrm{~mL})$ was added dropwise phosphorus oxychloride $(50.0 \mathrm{ml}, 536 \mathrm{mmol})$ (Note: a violent reaction occurred during the addition of the first few $\mathrm{mL}$ ). The reaction was stirred at reflux for 75 minutes and then the phosphorus oxychloride was removed by distillation. To the resulting material was added $\mathrm{H}_{2} \mathrm{O}(300 \mathrm{~mL})$. This solution was extracted with $\mathrm{CHCl}_{3}(4 \mathrm{X} 75 \mathrm{~mL})$. The combined organic phases were dried $\left(\mathrm{MgSO}_{4}\right)$, filtered and concentrated. The product was purified by recrystallization from $\mathrm{H}_{2} \mathrm{O}$ to give $218(5.64 \mathrm{~g}, 32.3 \mathrm{mmol}, 78 \%)$ as a pale yellow solid.

\section{6-Bromo-1,3-dimethyluracil ${ }^{92}$ (219).}

A solution of 1,3-dimethylbarbituric acid (224) $(1.00 \mathrm{~g}, 6.4 \mathrm{mmol})$ and phosphorus tribromide $(5.0 \mathrm{ml}, 53.0 \mathrm{mmol})$ was heated at reflux for 75 minutes. The solution was poured 
onto ice $(100 \mathrm{~mL})$ and extracted with EtOAc $(5 \mathrm{X} 30 \mathrm{~mL})$. The combined organic phases were dried $\left(\mathrm{MgSO}_{4}\right)$, filtered and concentrated. Purification by flash chromatography (hexanes/EtOAc, 8:2, 6:4 and 1:1) gave 219 (458 mg, $2.1 \mathrm{mmol}, 33 \%$ ) as a brown solid: ${ }^{1} \mathrm{H}$ NMR $\delta 6.16(\mathrm{~s}, 1 \mathrm{H}), 3.63$ (s, $3 \mathrm{H}), 3.33(\mathrm{~s}, 3 \mathrm{H}) ;{ }^{13} \mathrm{C} \mathrm{NMR}(150 \mathrm{MHz}) \delta 160.7(+), 150.7(+)$, $136.5(+), 105.9(-), 36.5(-), 28.2(-)$.

\section{6-Iodo-1,3-dimethyluracil ${ }^{93}$ (220).}

To a solution of $\mathrm{NaI}(3.04 \mathrm{~g}, 20.3 \mathrm{mmol})$ dissolved in acetone $(10 \mathrm{~mL})$ in a threaded pressure vessel was added 6-chloro-1,3-dimethyluracil (218) (500 $\mathrm{mg}, 2.9 \mathrm{mmol})$. The reaction vessel was then sealed with a Teflon cap and heated to $130{ }^{\circ} \mathrm{C}$ for $81 \mathrm{~h}$. The mixture was concentrated and $\mathrm{H}_{2} \mathrm{O}(75 \mathrm{~mL}$ ) was added. This solution was extracted with EtOAc (4 X 30 $\mathrm{mL})$. The combined organic phases were dried $\left(\mathrm{MgSO}_{4}\right)$, filtered and concentrated. The product was purified by recrystallization from EtOAc to give 220 (490 $\mathrm{mg}, 1.8 \mathrm{mmol}, 64 \%$ ) as a brown solid.

\section{2,2'-Dinitrobiphenyl ${ }^{69}$ (227) and 6-(2-nitrophenyl)-1,3-dimethyluracil (226).}

To a solution of 6-iodo-1,3-dimethyluracil (220) $(267 \mathrm{mg}, 1.0 \mathrm{mmol})$ and 2-(tri-nbutylstannyl)-1-nitrobenzene ${ }^{60}$ (225) (494 mg, $1.2 \mathrm{mmol}$ ) dissolved in $N$-methylpyrrolidinone (3 $\mathrm{mL}$ ) under argon atmosphere was added $\mathrm{PdCl}_{2}(\mathrm{PhCN})_{2}(23 \mathrm{mg}, 0.06 \mathrm{mmol})$, triphenylarsine (34 $\mathrm{mg}, 0.11 \mathrm{mmol})$ and $\mathrm{CuI}(21 \mathrm{mg}, 0.11 \mathrm{mmol})$. The reaction was stirred at reflux for $20 \mathrm{~h}$. The solution was diluted with EtOAc $(50 \mathrm{~mL})$ and washed with $\mathrm{NH}_{4} \mathrm{OH}(10 \%, 3$ X $20 \mathrm{~mL})$ and $\mathrm{H}_{2} \mathrm{O}$ $(2 \times 20 \mathrm{~mL})$. The combined aqueous layers were extracted with EtOAc $(2 \times 25 \mathrm{~mL})$. The combined organic phases were dried $\left(\mathrm{MgSO}_{4}\right)$, filtered and concentrated. Purification by flash 
chromatography (hexanes/EtOAc, 9:1, 8:2, 6:4, 1:1, 3:7 and EtOAc) gave 227 (53 mg, 0.22 mmol, 36\%) as a brown solid and 226 (126 mg, $0.48 \mathrm{mmol}, 48 \%$ ) as a tan solid: $226{ }^{1} \mathrm{H}$ NMR $\delta$ $8.28(\mathrm{dd}, J=7.9$ and $1.2 \mathrm{~Hz}, 1 \mathrm{H}), 7.86-7.72(\mathrm{~m}, 2 \mathrm{H}), 7.44(\mathrm{dd}, J=7.2$ and $1.7 \mathrm{~Hz}, 1 \mathrm{H}), 5.60(\mathrm{~s}$, $1 \mathrm{H}), 3.43$ (s, $3 \mathrm{H}), 3.13$ (s, $3 \mathrm{H}) ;{ }^{13} \mathrm{C}$ NMR $\delta 162.1,151.3,146.6,134.5,131.5,130.6,128.4$, $125.3,101.4,33.6,28.1$ (Note: one carbon signal is missing).

\section{1,3-Dimethyl-1H-pyrimido[5,4-b]indole-2,4(3H,5H)dione (228).}

The same procedure as described for 57 was repeated except that a mixture of 6-(2nitrophenyl)-1,3-dimethyluracil (226) (120 mg, $0.5 \mathrm{mmol}), \mathrm{Pd}(\mathrm{dba})_{2}$ (16 mg, $\left.0.03 \mathrm{mmol}\right)$, dppp (11 mg, $0.03 \mathrm{mmol})$, phen $(10 \mathrm{mg}, 0.06 \mathrm{mmol})$ and $\mathrm{DMF}(5 \mathrm{~mL})$ was reacted at $70{ }^{\circ} \mathrm{C}$ under $\mathrm{CO}$ (6 atm) for $24 \mathrm{~h}$. The reaction mixture was then concentrated. Purification by flash chromatography (hexanes/EtOAc, 9:1, 7:3, 1:1, 3:7 and EtOAc) gave 228 (9 mg, 0.04 mmol, 9\%) as a tan solid: ${ }^{1} \mathrm{H}$ NMR (600 MHz, DMSO-d $\left.\mathrm{d}_{6}\right) \delta 12.00(\mathrm{~s}, 1 \mathrm{H}), 8.08(\mathrm{~d}, J=7.8 \mathrm{~Hz}, 1 \mathrm{H})$, $7.47(\mathrm{~d}, J=8.4 \mathrm{~Hz}, 1 \mathrm{H}), 7.40(\mathrm{dt}, J=6.6$ and $0.6 \mathrm{~Hz}, 1 \mathrm{H}), 7.15(\mathrm{dt}, J=7.5 \mathrm{and} 0.6 \mathrm{~Hz}, 1 \mathrm{H})$, $3.84(\mathrm{~s}, 3 \mathrm{H}), 3.33(\mathrm{~s}, 3 \mathrm{H}) ;{ }^{13} \mathrm{C}$ NMR (150 MHz, DMSO-d 6 ) $\delta$ 155.9, 151.0, 138.1, 126.8, 126.6, $121.7,119.8,115.3,113.9,113.0,32.5,28.0$. 


\section{References}

1. Pardasani, R.T.; Jain, S.K.; Yadav, S.K.; Sharma, I. Indian Journal of Heterocyclic Chemistry 2002, 12, 179-180.

2. Menciu, C.; Duflos, M.; Fouchard, F.; Le Baut, G.; Emig, P.; Achterrath, U.; Szelenyi, I.; Nickel, B.; Schmidt, J.; Kutscher, B.; Guenther, E. J. Med. Chem. 1999, 42, 638-648.

3. Chaturvedula, V.S.P.; Sprague, S.; Schilling, J.K.; Kingston, D.G.I. J. Nat. Prod. 2003, $66,528-531$.

4. (a) Robinson, B. Chem. Rev. 1969, 69, 227-250. (b) Robinson, B. Chem. Rev. 1963, 63, 373-401.

5. Allen, C.F.H.; Van Allan, J. Org. Synth. 1955, Coll. Vol. 3, 597-599.

6. Bashford, K.E.; Cooper, A.L.; Kane, P.D.; Moody, C.J.; Muthusamy, S.; Swann, E. J. Chem. Soc., Perkin Trans. 1 2002, 14, 1672-1687.

7. $\quad$ Söderberg, B.C.; Shriver, J.A. J. Org. Chem. 1997, 62, 5838-5845.

8. Hegedus, L.S.; Allen, G.F.; Bozell, J.J.; Waterman, E.L. J. Am. Chem. Soc. 1978, 100, 5800-5807.

9. Taylor, E.C.; Katz, A.H.; Salgado-Zamora, H.; McKillop, A. Tetrahedron Lett. 1985, 26, 5963-5966.

10. Ponticello G.S.; Baldwin J.J. J. Org. Chem. 1979, 44, 4003-4005.

11. Romer, D.R.; Aldrich, B.L.; Pews, R.G.; Walter, R.W., Jr. Pesticide Science 1995, 43, 263-266.

12. Ortega, M.A.; Montoya, M.E.; Jaso, A.; Zarranz, B.; Tirapu, I.; Aldana, I.; Monge, A. Pharmazie 2001, 56, 205-207.

13. Zarnowski, T.; Kleinrok, Z.; Turski, W.A.; Czuczwar, S.J. Neuropharmacology 1993, 32, 895-900.

14. Metzner, J.; Lippmann, E.; Weber, F.G.; Westphal, G. Pharmazie 1981, 36, 368-370.

15. (a) Toshima, K.; Kimura, T.; Takano, R.; Ozawa, T.; Ariga, A.; Shima, Y.; Umezawa, K.; Matsumura, S. Tetrahedron 2003, 59, 7057-7066. (b) Vitale, G.; Corona, P.; Loriga, M.; Paglietti, G. Farmaco 1998, 53, 150-159. 
16. Katoh, A.; Yoshida, T.; Ohkanda, J. Heterocycles 2000, 52, 911-920.

17. Ali, M.M.; Ismail, M.M.F.; El-Gaby, M.S.A.; Zahran, M.A.; Ammar, Y.A. Molecules 2000, 5, 864-873.

18. Loriga, M.; Nuvole, A.; Paglietti, G. J. Chem. Res. Synop. 1989, 202-203.

19. Kano, S.; Yuasa, Y. Heterocycles 1981, 16, 1449-1452.

20. McKillop, A.; Chattopadhyay, S.K.; Henderson, A.; Avendano, C. Synthesis 1997, 3, 301-304.

21. (a) Kurasawa, Y.; Takada, A. Heterocycles 1985, 23, 2083-2119. (b) Iwanami, Y. J. Chem. Soc. Japan, Pure Chem. Soc. 1961, 82, 778-780.

22. Makino, K.; Sakata, G.; Morimoto, K. Heterocycles 1985, 23, 1729-1734.

23. Krchňák, V.; Szabo, L.; Vágner, J. Tetrahedron Lett. 2000, 41, 2835-2838.

24. Kobayashi, K.; Matsumoto, T.; Irisawa, S.; Yoneda, K.; Morikawa, O.; Konishi, H. Heterocycles 2001, 55, 973-980.

25. Mukhopadhyay, R.; Kundu, N. Tetrahedron Lett. 2000, 41, 9927-9930.

26. (a) Kozmin, S.A.; Janey, J.M.; Rawal, V.H. J. Org. Chem. 1999, 64, 3039-3047. (b) Lienhard, U.; Fahrni, H.-P.; Neuenschwander, M. Helv. Chim. Acta 1978, 61, 16091621.

27. (a) Chu, J.H.; Murty, B.S.R.; Fedor, L. J. Am. Chem. Soc. 1976, 98, 3632-3635. (b) Dudek, G.O.; Holm, R.H. J. Am. Chem. Soc. 1962, 84, 2691-2696.

28. (a) Molina, P.; Arques, A.; Vinader, M.V. J. Org. Chem. 1988, 53, 4654-4663. (b) Staudinger, H.; Meyer, J. Helv. Chim. Acta 1919, 2, 635-646.

29. Bartoszek, M.; Salzwedel, D.; Stumm, G.; Niclas, H.-J. Organic Mass Spectrometry 1987, 22, 259-268.

30. Söderberg, B.C.G. Curr. Org. Chem. 2000, 4, 727-764.

31. Crotti, C.; Cenini, S.; Bassoli, A.; Rindone, B.; Demartin, F. J. Mol. Catal. 1991, 70, 175-187.

32. Ragaini, F.; Cenini, S.; Tollari, S.; Tummollilo, G.; Beltrami, R. Organometallics 1999, $18,928$.

33. Alajarín, M.; Vidal, A.; Tovar, F.; Conesa, C. Tetrahedron Lett. 1999, 40, 6127-6130. 
34. Krbechek, L.; Takimoto, H. J. Org. Chem. 1964, 29, 3630-3632.

35. Fourquet, J.L.; LeBlanc, M.; Saravanamuthu, A.; Bruce, M.R.M.; Bruce, A.E. Inorg. Chem. 1991, 30, 3241-3243.

36. Massey, S.T.; Mansour, B.; McElwee-White, L. J. Organomet. Chem. 1995, 485, $123-$ 126.

37. Abramovitch, R.A.; Azogu, C.I.; Sutherland, R.G. Tetrahedron Lett. 1971, 20, 16371640.

38. (a) Haddadin, M.J.; Bitar, H.E.; Issidorides, C.H. Heterocycles 1979, 12, 323-327. (b) Nazer, M.Z.; Haddadin, M.J.; Petridou, J.P.; Issidorides, C.H. Heterocycles 1977, 6, 541-545.

39. Pandey, V.K.; Raj, N. Current Science 1986, 55, 848-850.

40. Skibo, E.B. Current Medicinal Chemistry 1996, 3, 47-78.

41. Townsend, L.B.; Wise, D.S. Parisitology Today 1990, 6, 107-112.

42. Langcake, P.; Kuhn, P.J.; Wade, M. Progress in Pesticide Biochemistry and Toxicology 1983, 3, 1-109.

43. Holmes, D.S.; Bethell, R.C.; Cammack, N.; Clemens, I.R.; Kitchin, J.; McMeekin, P.; Mo, C.L.; Orr, D.C.; Patel, B.; Paternoster, I.L.; Storer R. J. Med. Chem. 1993, 36, 3129-3136.

44. Ellingboe, J.W.; Spinelli, W.; Winkley, M.W.; Nguyen, T.T.; Parsons, R.W.; Moubarak, I.F.; Kitzen, J.M.; Von Engen, D.; Bagli, J.F. J. Med. Chem. 1992, 35, 705-716.

45. Navarro-Ocaña, A.; Olguín, L.F.; Luna, H.; Jiménez-Estrada, M.; Bárzana, E. J. Chem. Soc., Perkin Trans. 1 2001, 21, 2754-2756.

46. Grenda, V.J.; Jones, R.E.; Gal, G.; Sletzinger, M. J. Org. Chem. 1965, 30, 259-261.

47. Wang, H.; Partch, R.E.; Li, Y. J. Org. Chem. 1997, 62, 5222-5225.

48. Perry, R.J.; Wilson, B.D. J. Org. Chem. 1993, 58, 7016-7021.

49. Thomas, A.P.; Allott, C.P.; Gibson, K.H.; Major, J.S.; Masek, B.B.; Oldham, A.A.; Ratcliffe, A.H.; Roberts, D.A.; Russell, S.T.; Thomason, D.A. J. Med. Chem. 1992, 35, 877-885.

50. Cohen, V.I.; Pourabass, S. J. Heterocycl. Chem. 1977, 14, 1321-1323. 
51. Crotti, C.; Cenini, S.; Ragaini, F.; Porta, F.; Tollari, S. J. Mol. Catal. 1992, 72, 283-298.

52. Cadogan, J.I.G.; Marshall, R.; Smith, D.M.; Todd, M.J. J. Chem. Soc. (C) 1970, 18, 2441-2443.

53. Hall, J.H.; Kamm, D.R. J. Org. Chem. 1965, 30, 2092-2093.

54. Hall, J.H.; Patterson, E. J. Am. Chem. Soc. 1967, 89, 5856-5861.

55. (a) Song, Y.; Coupar, I.M.; Iskander, M.N. Quantitative Structure-Activity Relationships 2001, 20, 23-30. (b) Shin, H.K.; Shin, Y.W.; Hong, K.W. American Journal of Physiology 2000, 278, H339-H344. (c) Mallesh, K.; Kavitha, T.; Reddy, V.M. Acta Ciencia Indica, Physics 1989, 15, 67-74.

56. Cowden, W.B.; Halladay, P.K.; Cunningham, R.B.; Hunt, N.H.; Clark, I.A. J. Med. Chem. 1991, 34, 1818-1822.

57. Gorvin, J.H. J. Chem. Soc., Perkin Trans. 1 1988, 6, 1331-1335.

58. (a) Wolfe, J.P.; Buchwald, S.L. J. Org. Chem. 2000, 65, 1144-1157. (b) De Riccardis, F.; Bonala, R.R.; Johnson, F. J. Am. Chem. Soc. 1999, 121, 10453-10460.

59. Ishida, A.; Inage, M.; Akatsuka, H.; Inamasu, M.; Mitsui, T. Jpn. Kokai Tokkyo Koho 1994, JP06220059.

60. Kosugi, M.; Ohya, T.; Migita, T. Bull. Chem. Soc. Japan 1983, 56, 3855-3856.

61. Johnston, D.; Smith, D.M. J. Chem. Soc., Perkin Trans. 1 1976, 4, 399-404.

62. Battistini, M.; Erba, E.; Pocar, D. J. Chem. Soc., Perkin Trans. 1 1993, 3, 339-342.

63. Lai, J.T. Synthesis 1982, 1, 71-74.

64. Newman, M.S.; Kannan, R. J. Org. Chem. 1976, 41, 3356-3359.

65. Makosza, M.; Bia-lecki, M. J. Org. Chem. 1998, 63, 4878-4888.

66. Suzuki, K.; Komatsu, T.; Ina, S.; Fujii, K.; Kojima, J.; Yamana, K. Jpn. Kokai Tokkyo Koho 1992, JP04282314.

67. Inouye, G. Nippon Kagaku Zasshi 1954, 75, 732-734.

68. Meichsner, C.; Riess, G.; Kleim, J.P.; Roesner, M.; Paessens, A.; Blunck, M. Eur. Pat. Appl. 1995, 657166.

69. Commercially available. 
70. Roth, T.; Morningstar, M.L.; Boyer, P.L.; Hughes, S.H.; Buckheit, R.W., Jr.; Michejda, C.J. J. Med. Chem. 1997, 40, 4199-4207.

71. Yields were calculated from ${ }^{1} \mathrm{H}$ NMR.

72. Abdulla, R.F. Tetrahedron Lett. 1974, 40, 3559-3562.

73. Petukhov, P.A.; Tkachev, A.V. Tetrahedron 1997, 53, 9761-9768.

74. Glombik, H.; Utz, R.; Lang, H.J.; Geisen, K.; Beyhl, F.E. Eur. Pat. Appl. 1988, EP288898.

75. Capperucci, A.; Degl'Innocenti, A.; Funicello, M.; Mauriello, G.; Scafato, P.; Spagnolo, P. J. Org. Chem. 1995, 60, 2254-2256.

76. Tan, K.L.; Bergman, R.G.; Ellman, J.A. J. Am. Chem. Soc. 2002, 124, 13964-13965.

77. Visentin, S.; Amiel, P.; Fruttero, R.; Boschi, D.; Roussel, C.; Giusta, L.; Carbone, E.; Gasco, A. J. Med. Chem. 1999, 42, 1422-1427.

78. Novak, M.; Kahley, M.J.; Lin, J.; Kennedy, S.A.; James, T.G. J. Org. Chem. 1995, 60, 8294-8304.

79. Benchidmi, M.; El Kihel, A.; Essassi, E.M.; Knouzi, N.; Toupet, L.; Danion-Bougot, R.; Carrie, R. Bulletin des Societes Chimiques Belges 1995, 104, 605-611.

80. Amenta, D.S.; Mallory, F.B. J. Org. Chem. 1980, 45, 5236-5238.

81. Hannout, I.B.; Hassan, E.A.; Islam, A.M.; Ismail, I.M. United Arab Republic Journal of Chemistry 1970, 13, 199-212.

82. Vamecq, J.; Bac, P.; Herrenknecht, C.; Maurois, P.; Delcourt, P.; Stables, J.P. J. Med. Chem. 2000, 43, 1311-1319.

83. Stead, C.V. (Imperial Chemical Industries Ltd.) Brit. Pat. Appl. 1962, GB19590923.

84. Hall, J.; Dolan, F.W. J. Org. Chem. 1978, 43, 4608-4612.

85. Bhangadia, R.; Khadikar, P.V.; Agrawal, J.K. Indian Journal of Chemistry, Section A 1999, 38A, 170-172.

86. Suo, R.; Wang, G.; Pang, Z. Beijing Huagong Daxue Xuebao 1999, 26, 27-30.

87. Chaudhury, S.; Debroy, A.; Mahajan, M.P. Can. J. Chem. 1982, 60, 1122-1126.

88. Russell, G.A.; Wang, L.; Rajaratnam, R. J. Org. Chem. 1996, 61, 8988-8991. 
89. Hasan, M.; Mali, F.; Alvarez, M.C.G.; Yunus, U.; Rashid, N.; Maqbool, Z. J. Chem. Soc. Pak. 1990, 12, 80-83.

90. Mathias, L.J.; Overberger, C.G. J. Org. Chem. 1978, 43, 3526-3530.

91. Dubey, P.K.; Ratnam, C.V. Indian Journal of Chemistry, Section B 1978, 16B, 531-533.

92. Szilagyi, G.; Wamhoff, H. Synthesis 1981, 9, 701-702.

93. Saito, I.; Ikehira, H.; Matsuura, T. J. Org. Chem. 1986, 51, 5148-5153. 


\section{Appendix}




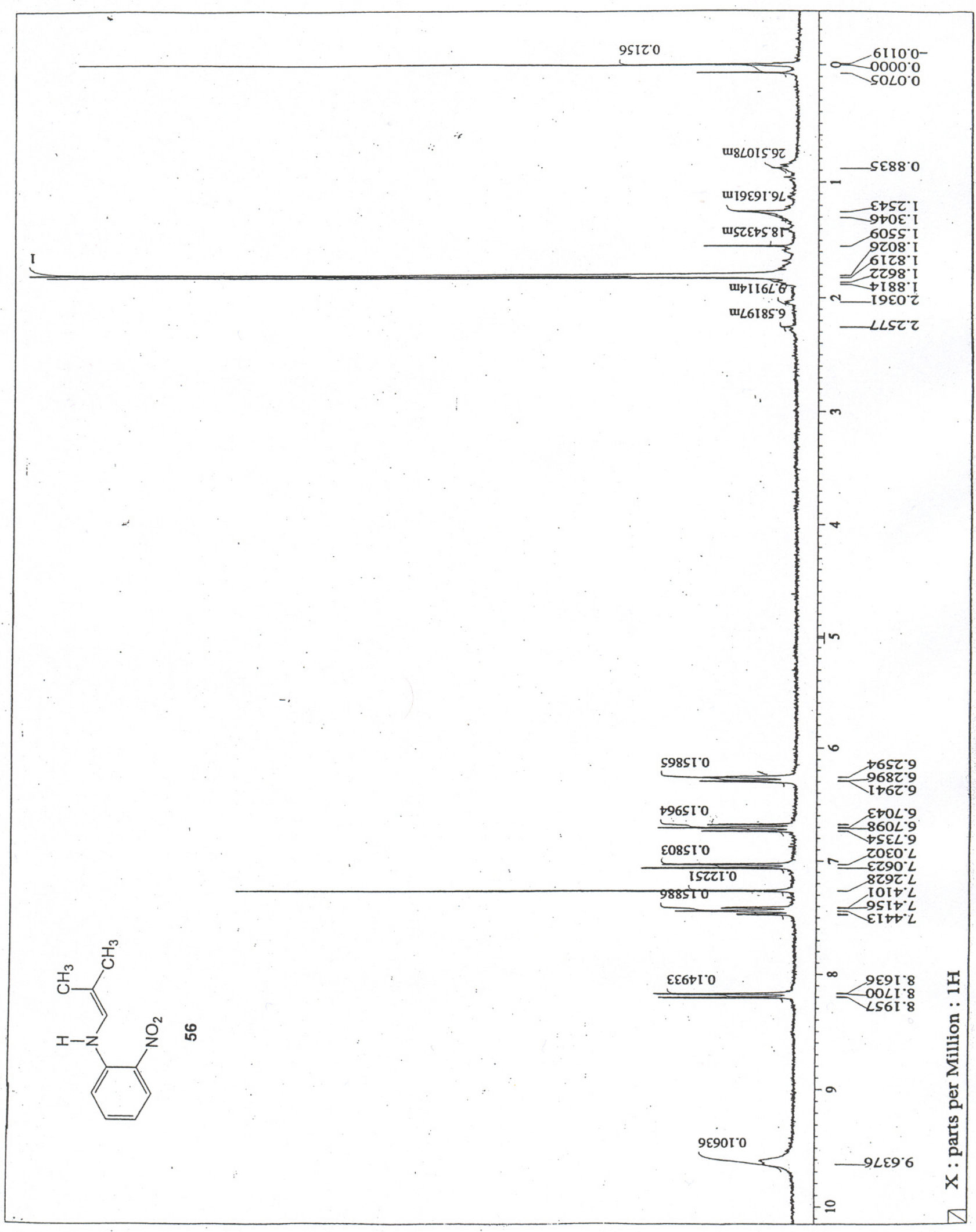

Figure 7: ${ }^{1} \mathrm{H}$ NMR of Compound 56 


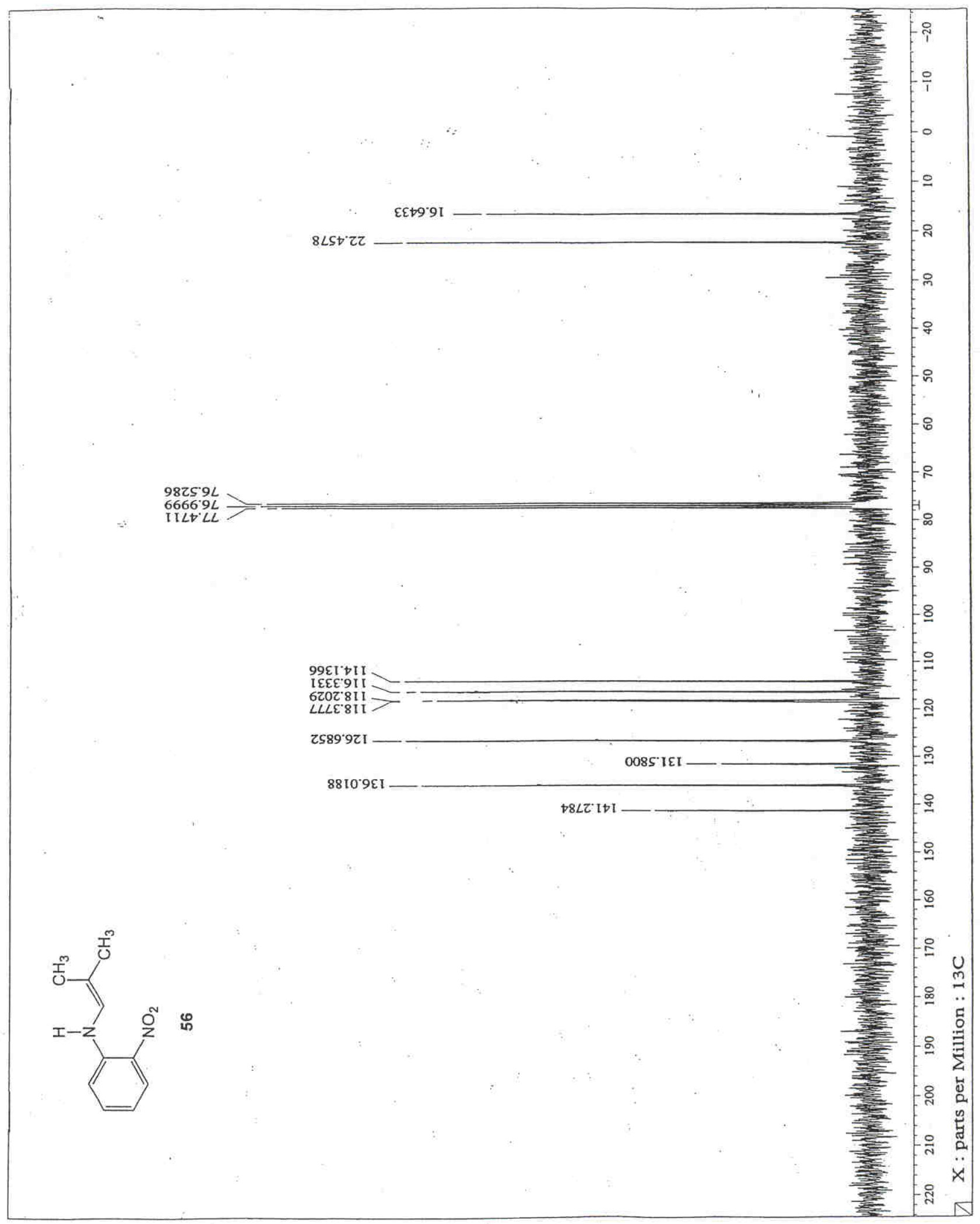

Figure 8: ${ }^{13} \mathrm{C}$ NMR of Compound $\mathbf{5 6}$ 


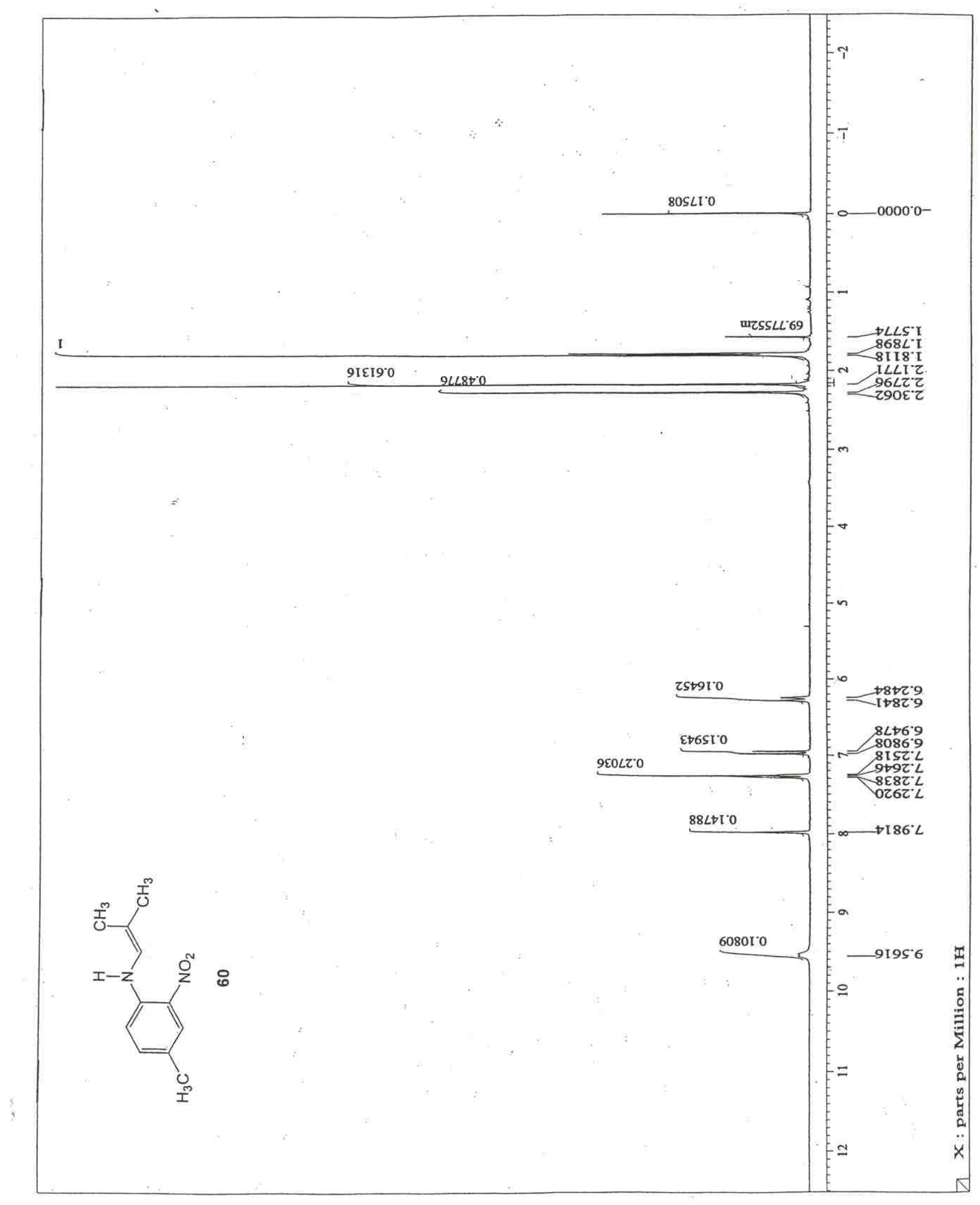

Figure 9: ${ }^{1} \mathrm{H}$ NMR of Compound 60 


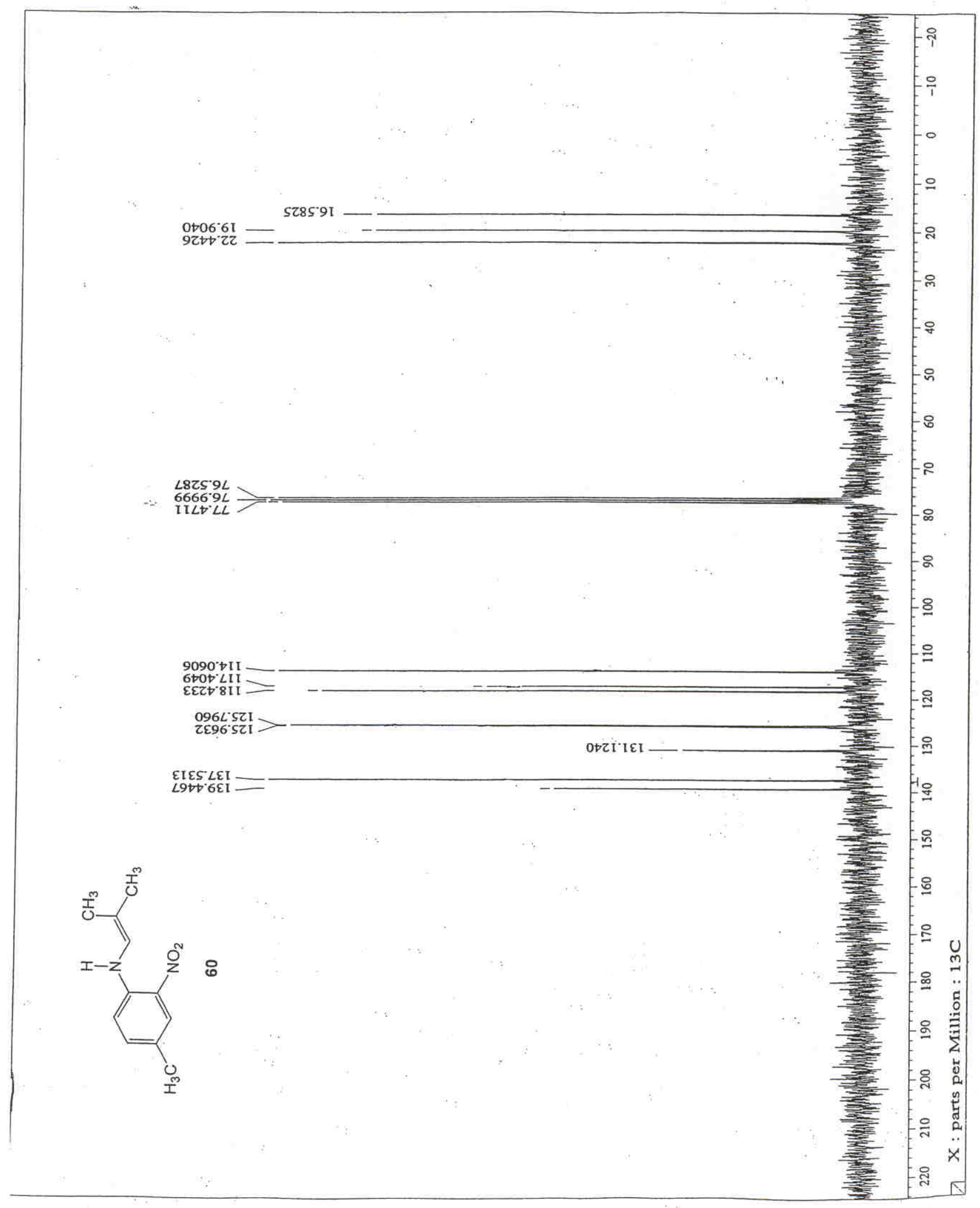

Figure 10: ${ }^{13} \mathrm{C}$ NMR of Compound 60 


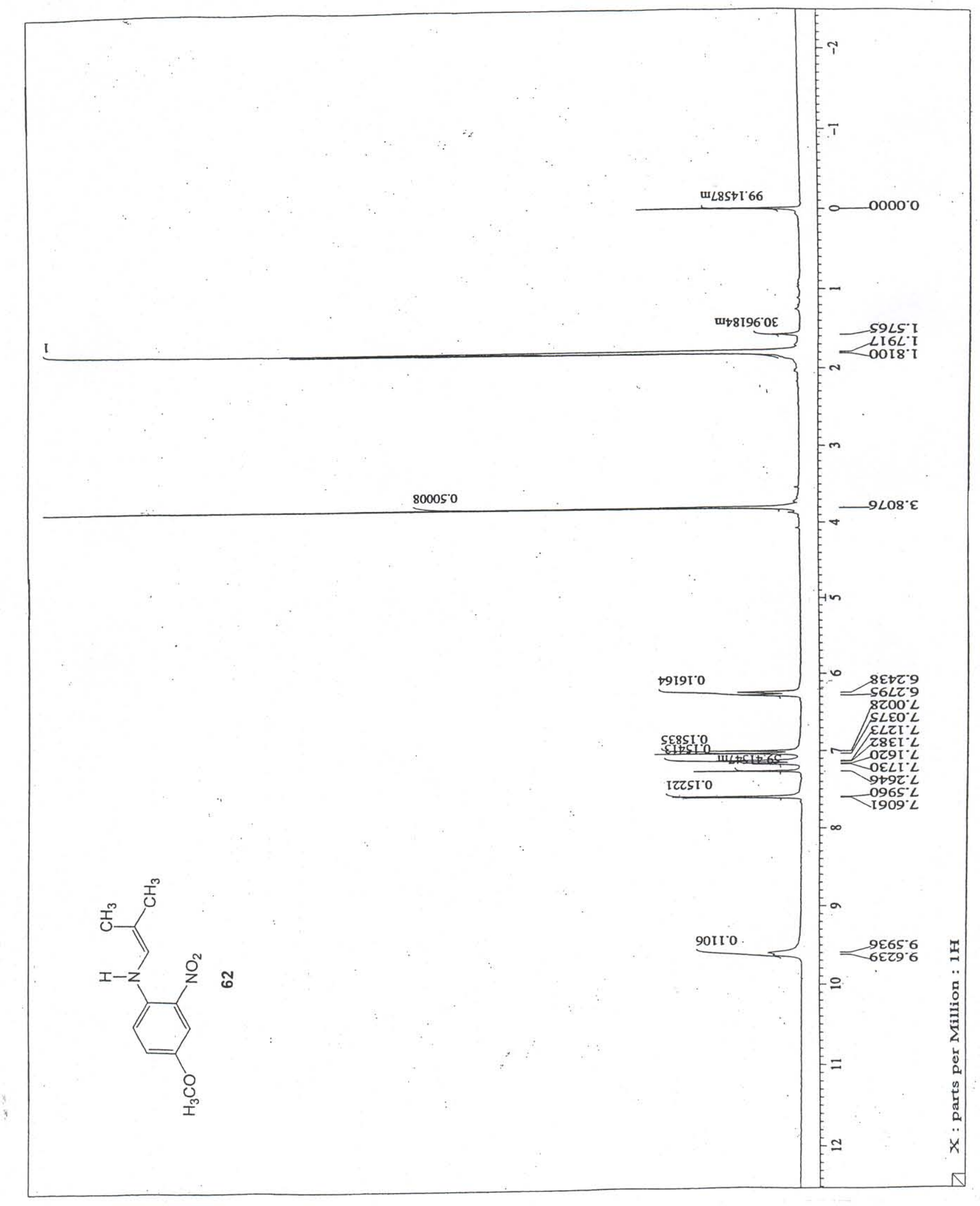

Figure 11: ${ }^{1} \mathrm{H}$ NMR of Compound 62 


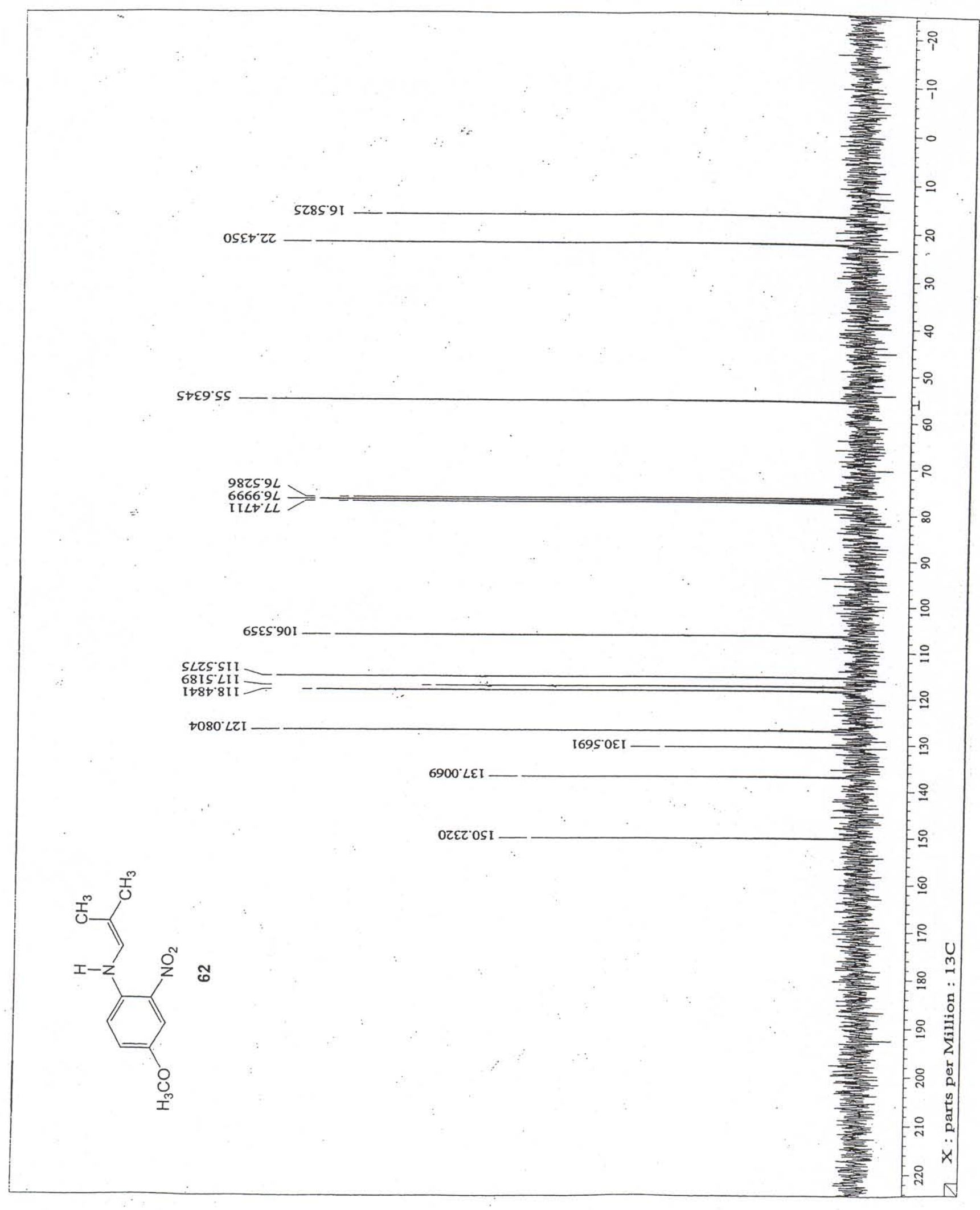

Figure 12: ${ }^{13} \mathrm{C}$ NMR of Compound 62 


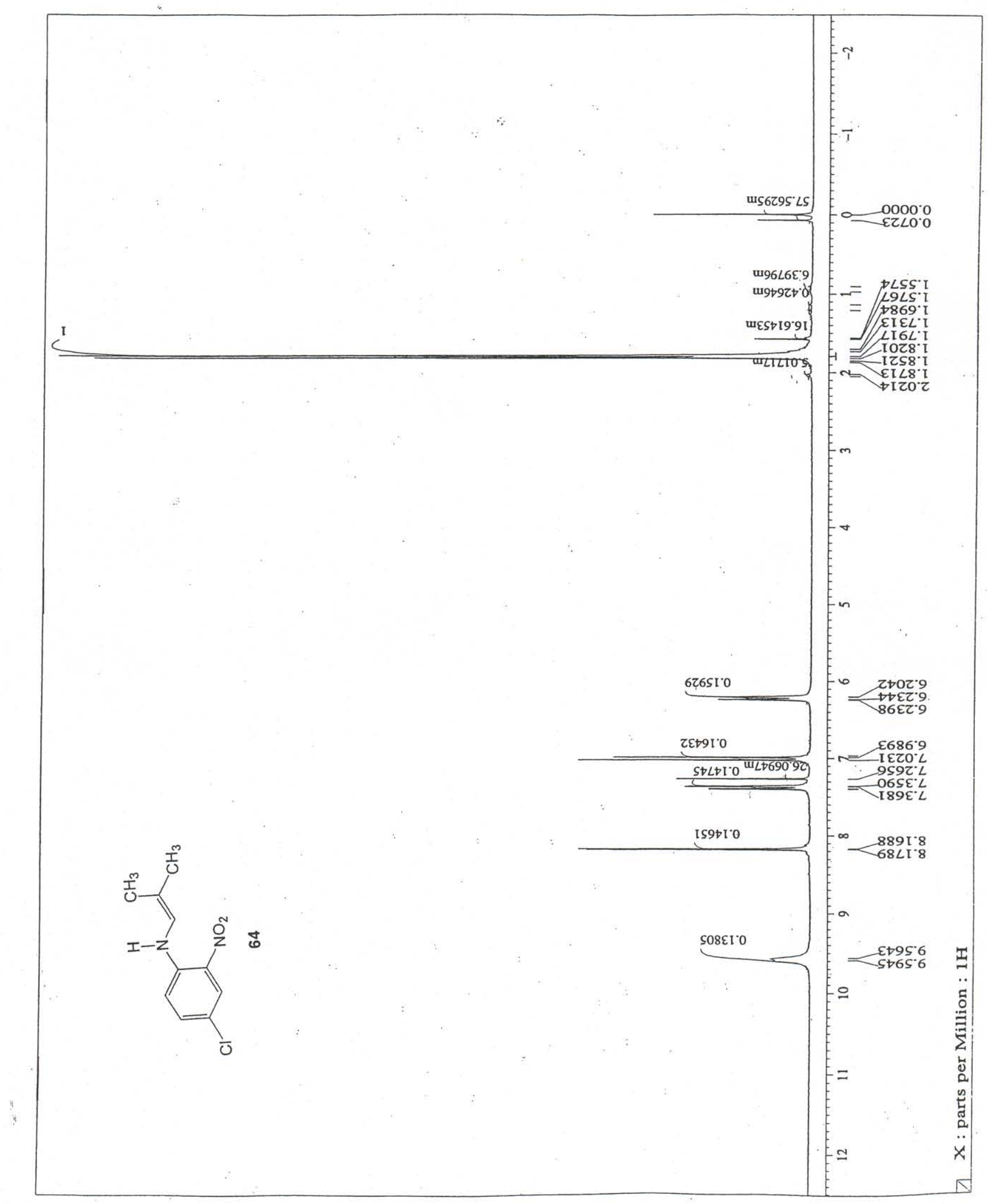

Figure 13: ${ }^{1} \mathrm{H}$ NMR of Compound 64 


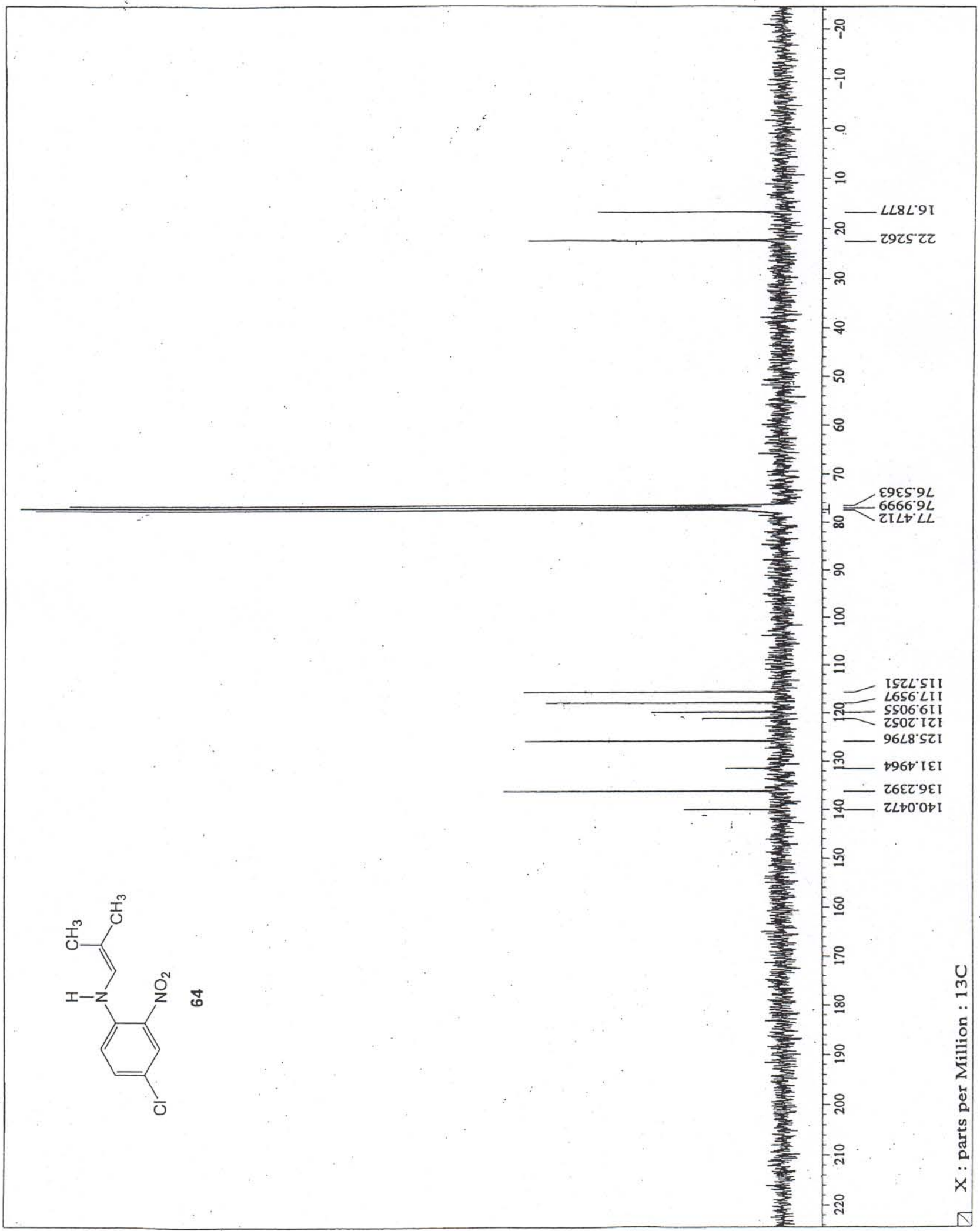

Figure 14: ${ }^{13} \mathrm{C}$ NMR of Compound 64 


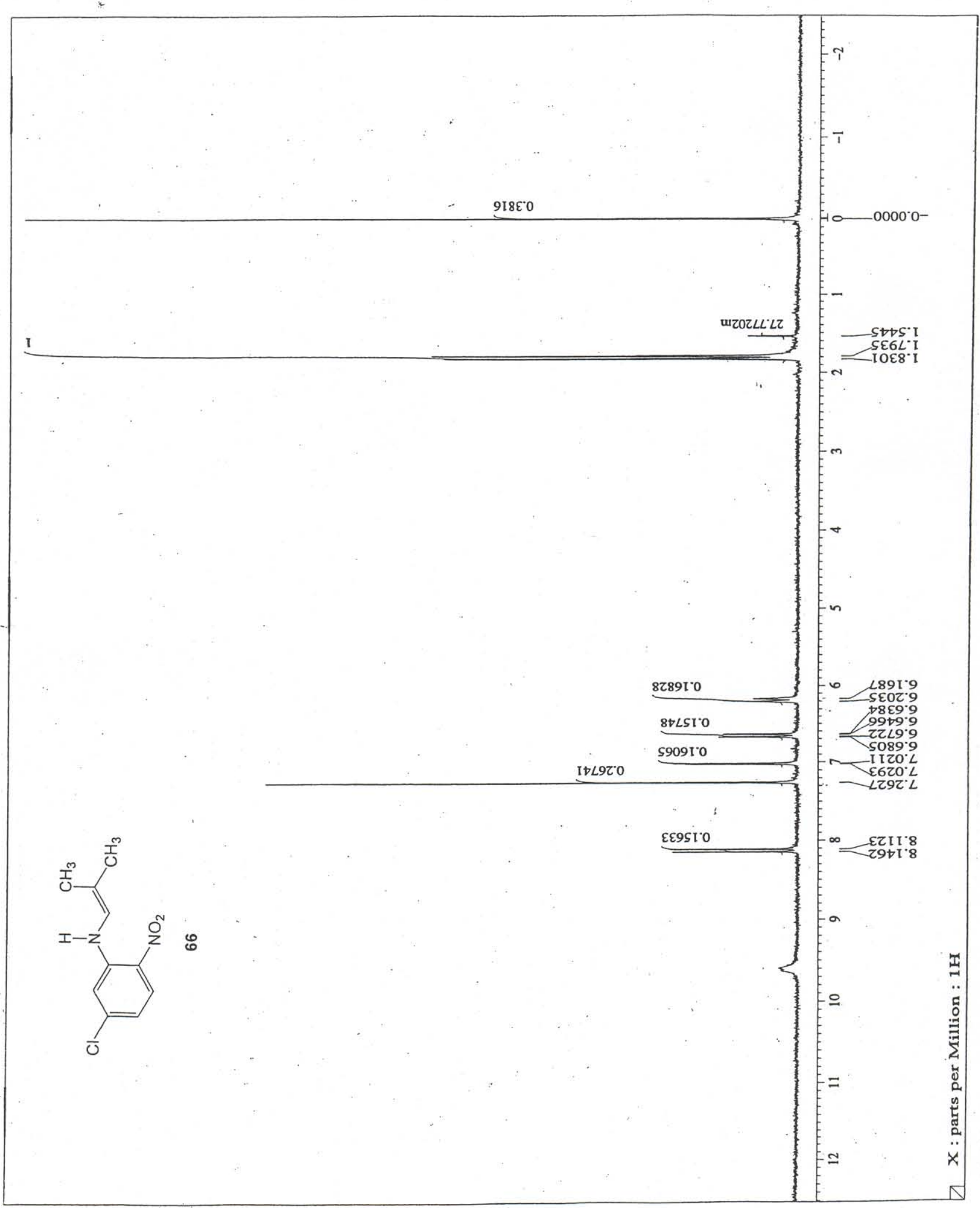

Figure 15: ${ }^{1} \mathrm{H}$ NMR of Compound 66 


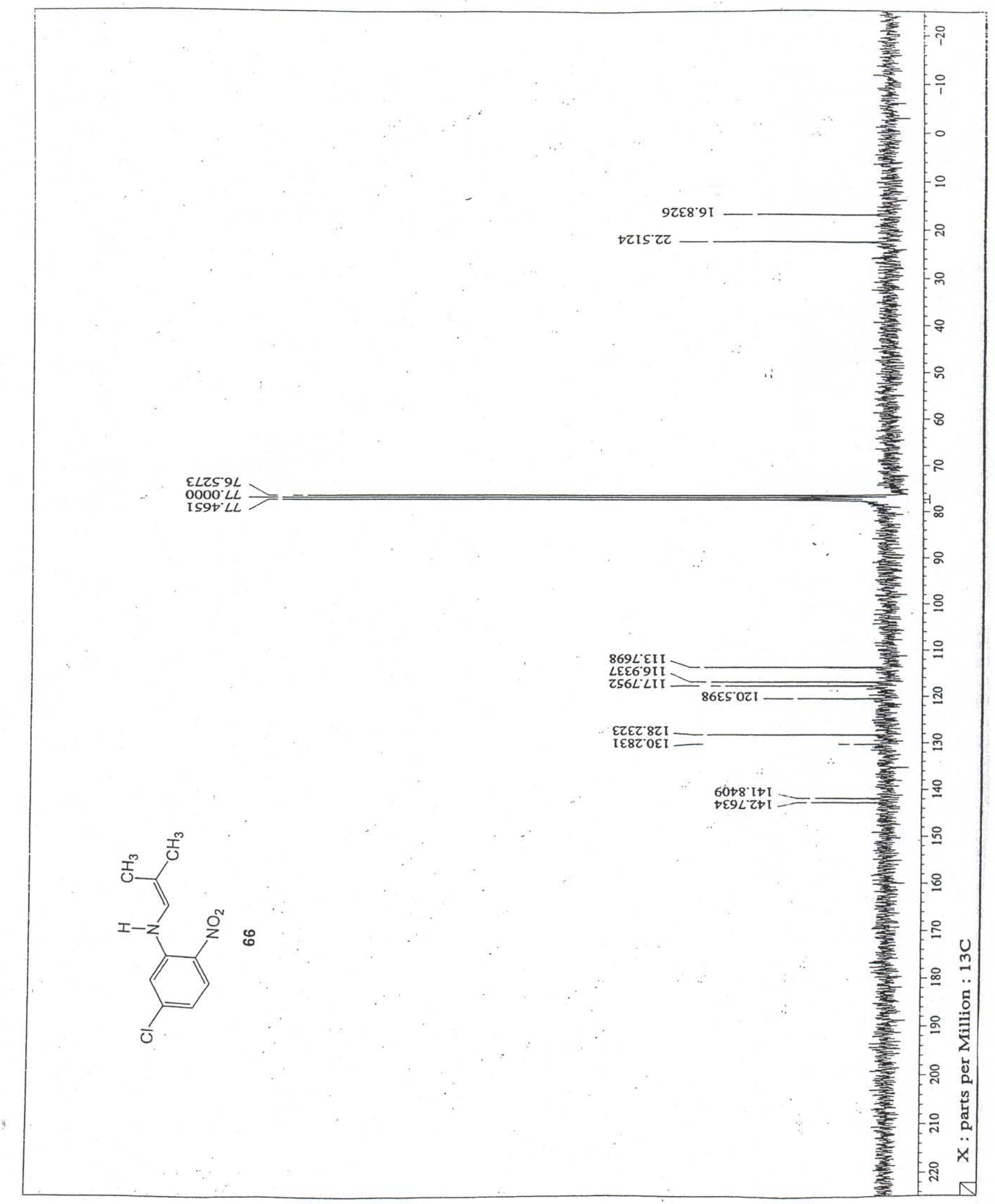

Figure 16: ${ }^{13} \mathrm{C}$ NMR of Compound 66 


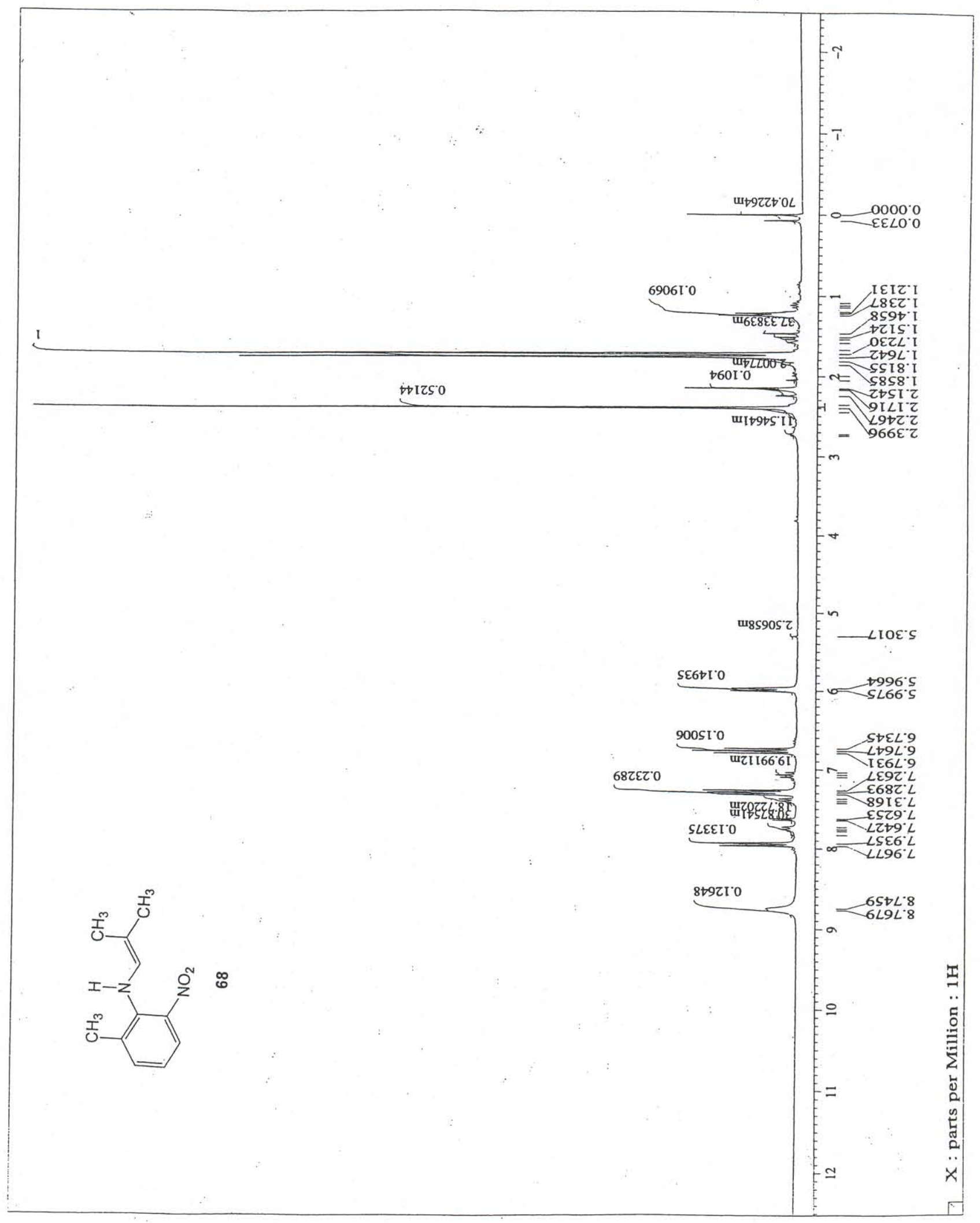

Figure 17: ${ }^{1} \mathrm{H}$ NMR of Compound 68 


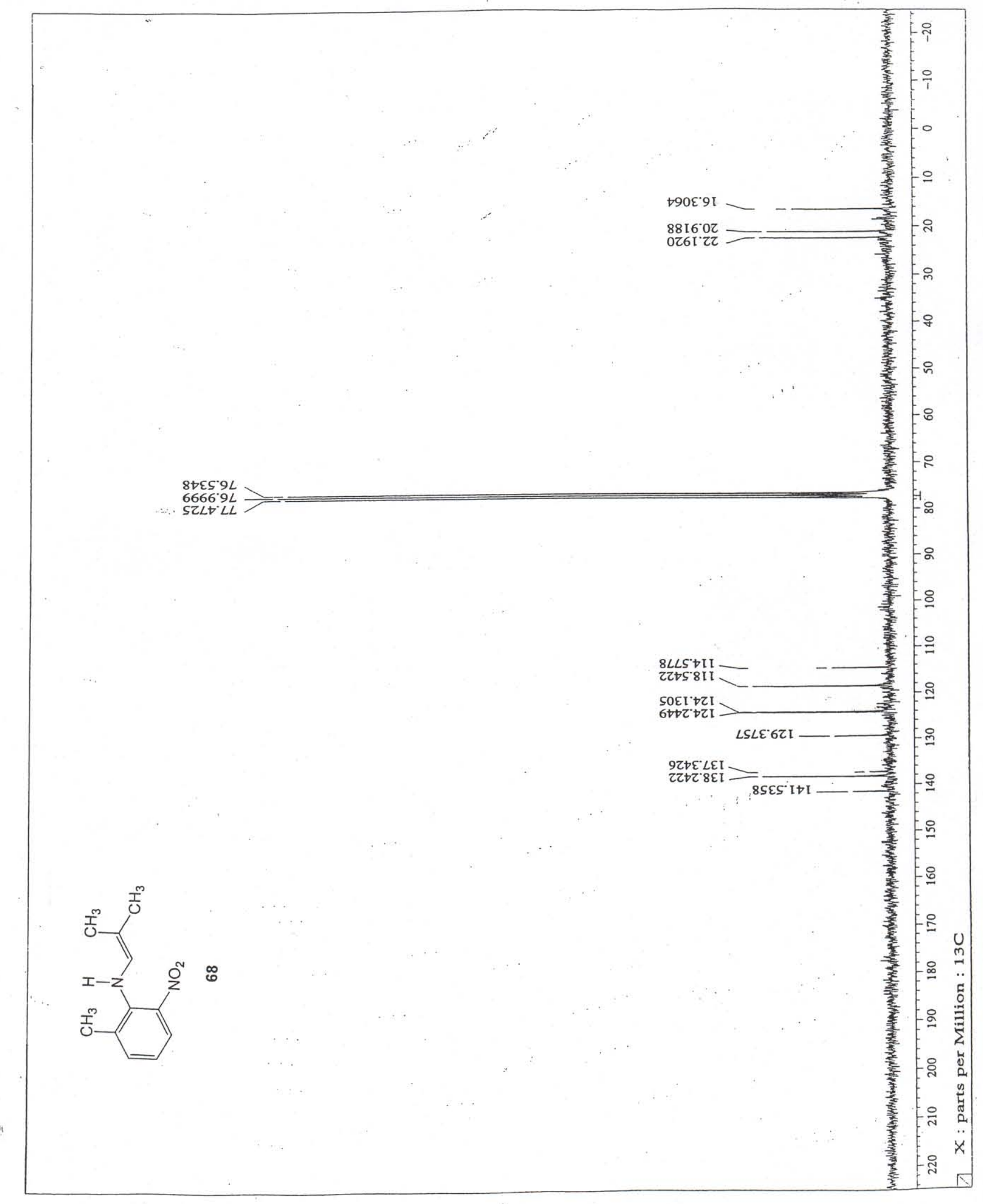

Figure 18: ${ }^{13} \mathrm{C}$ NMR of Compound 68 


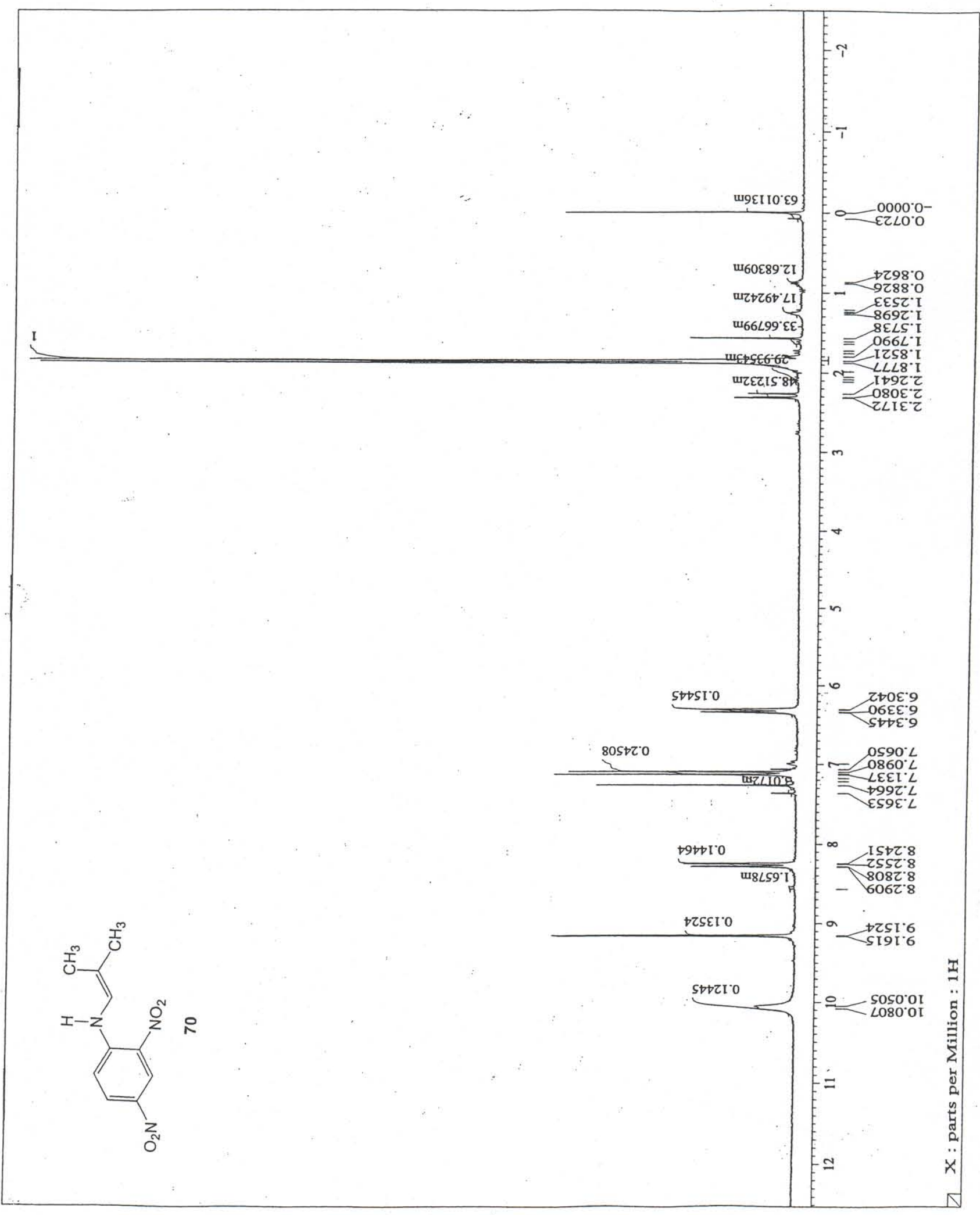

Figure 19: ${ }^{1} \mathrm{H}$ NMR of Compound 70 


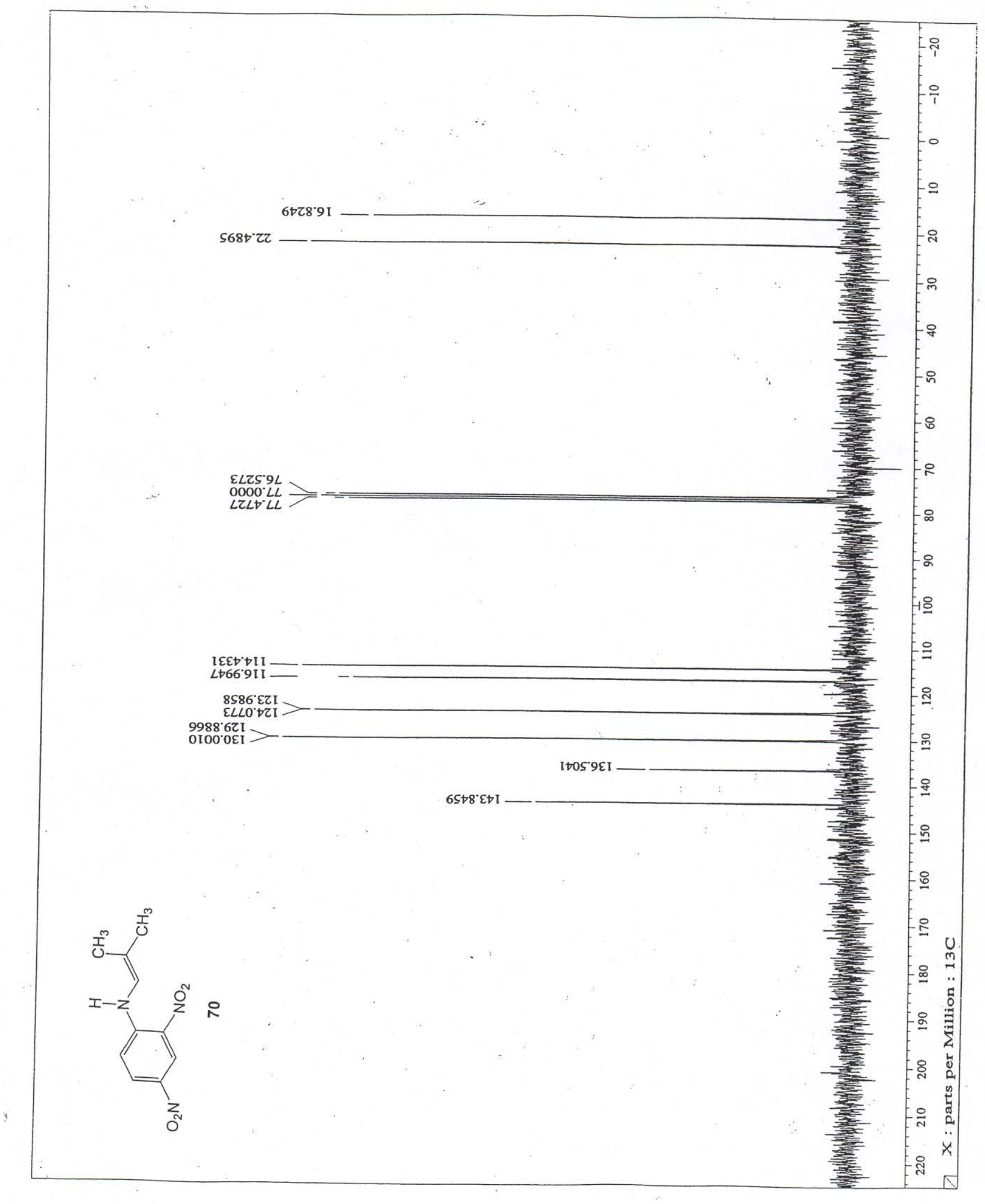

Figure 20: ${ }^{13} \mathrm{C}$ NMR of Compound 70 


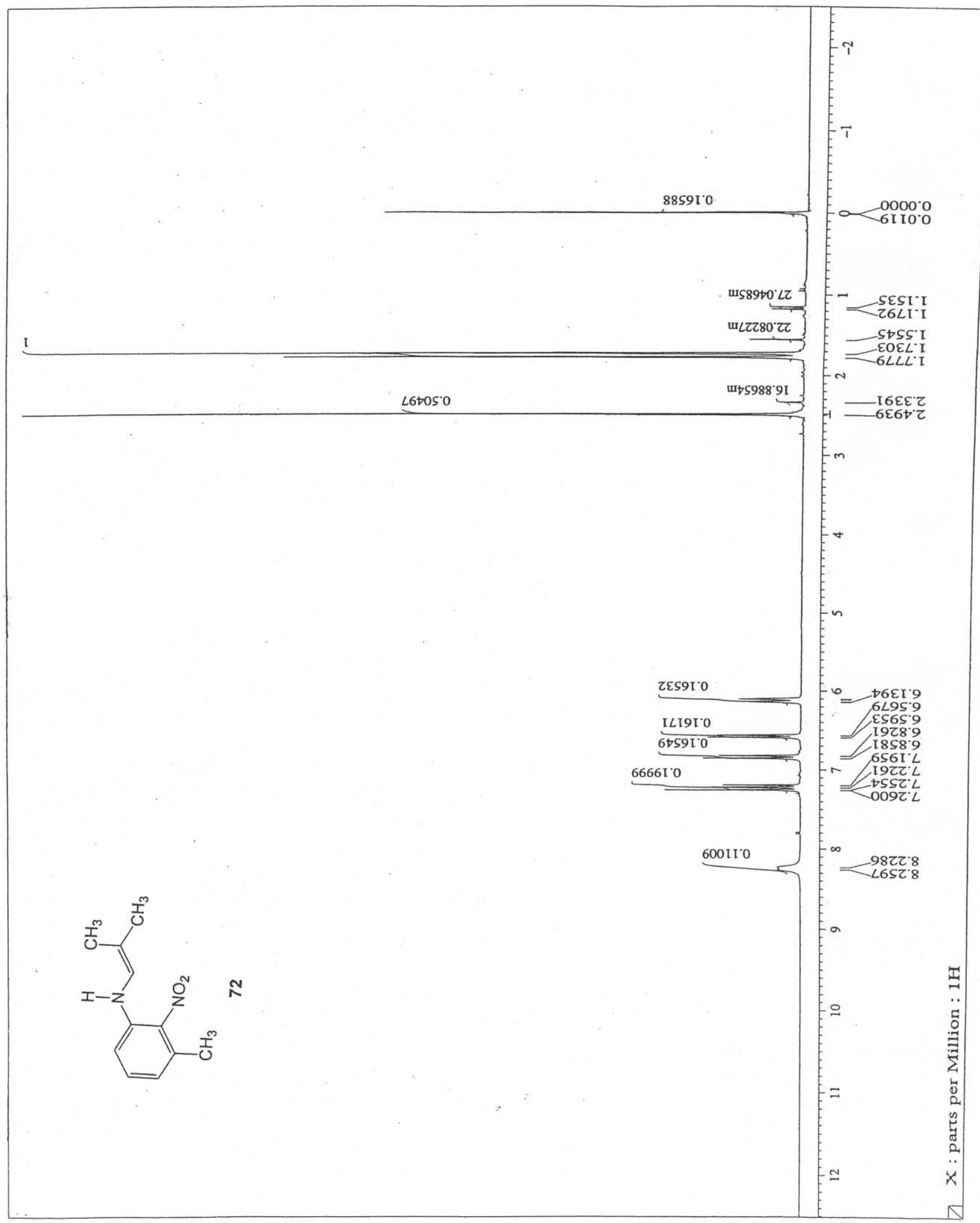

Figure 21: ${ }^{1} \mathrm{H}$ NMR of Compound 72 


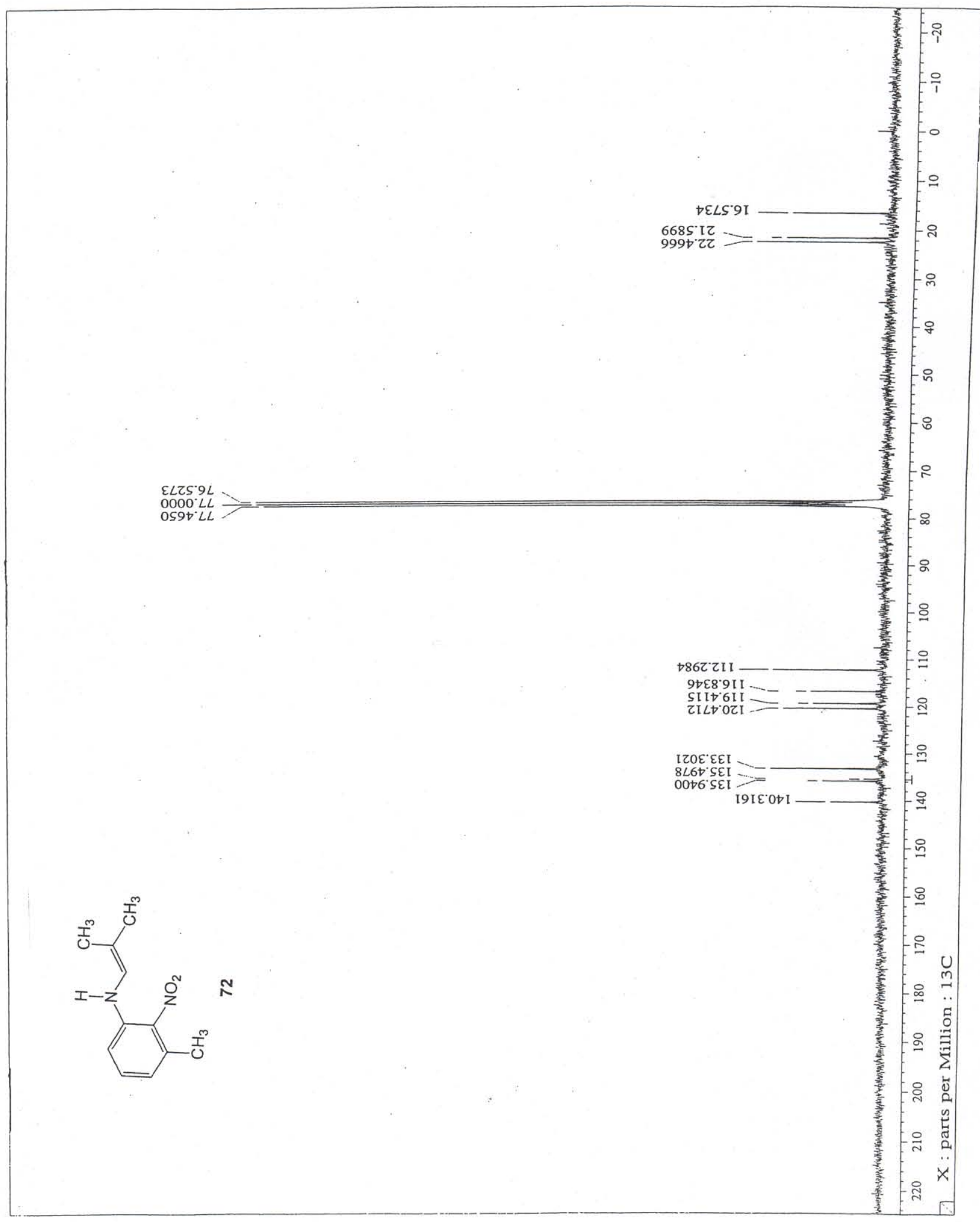

Figure 22: ${ }^{13} \mathrm{C}$ NMR of Compound 72 


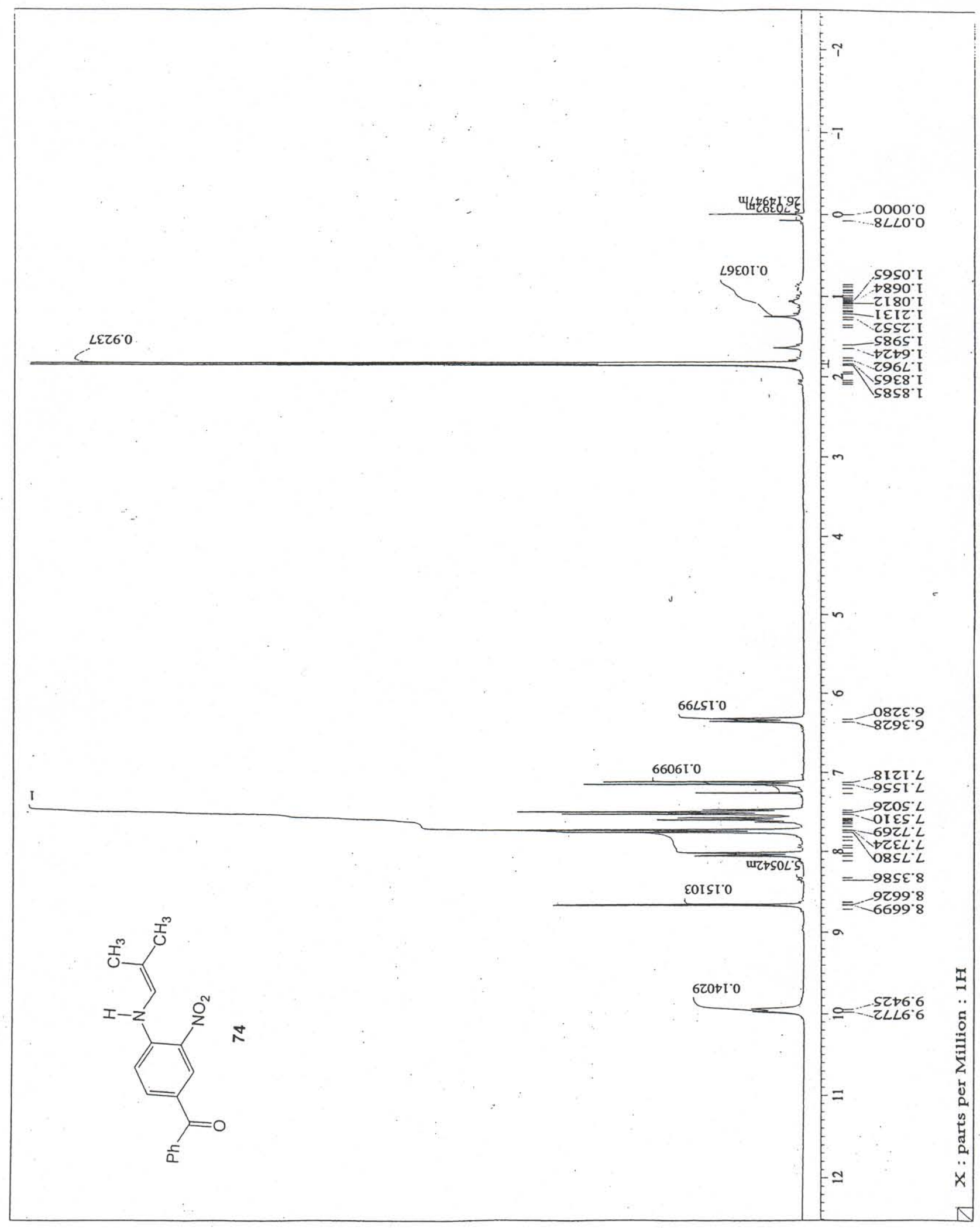

Figure 23: ${ }^{1} \mathrm{H}$ NMR of Compound 74 


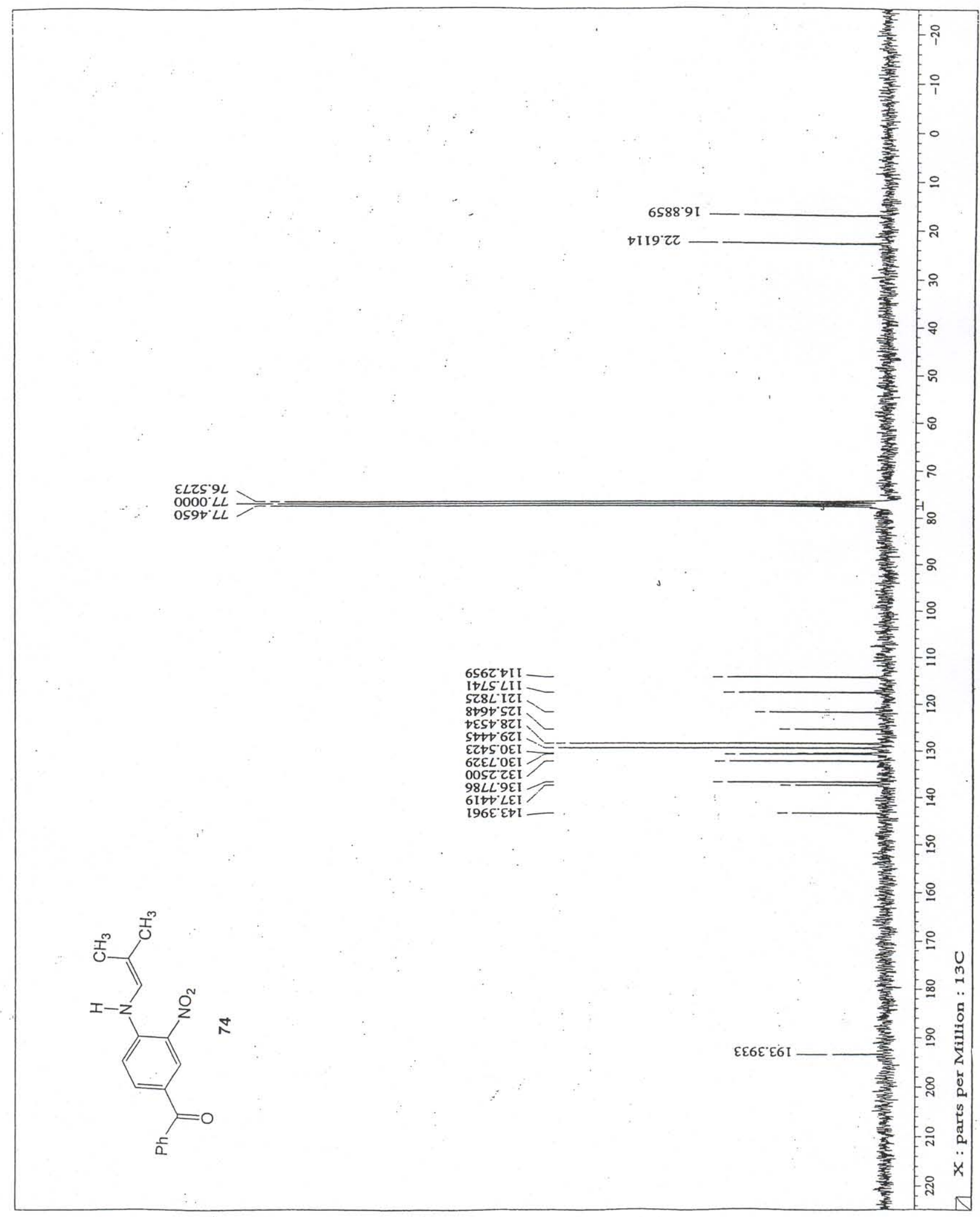

Figure 24: ${ }^{13} \mathrm{C}$ NMR of Compound 74 


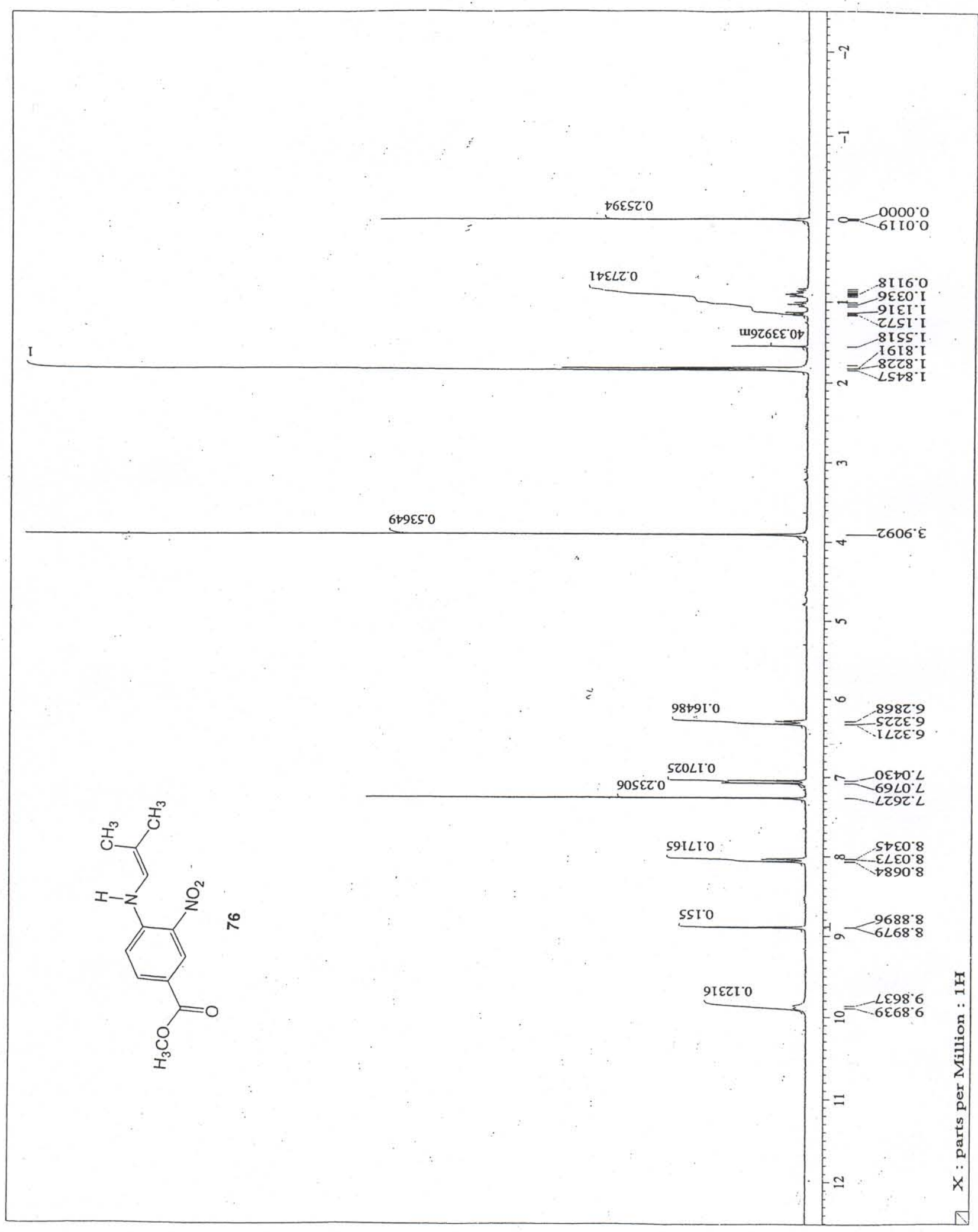

Figure 25: ${ }^{1} \mathrm{H}$ NMR of Compound 76 


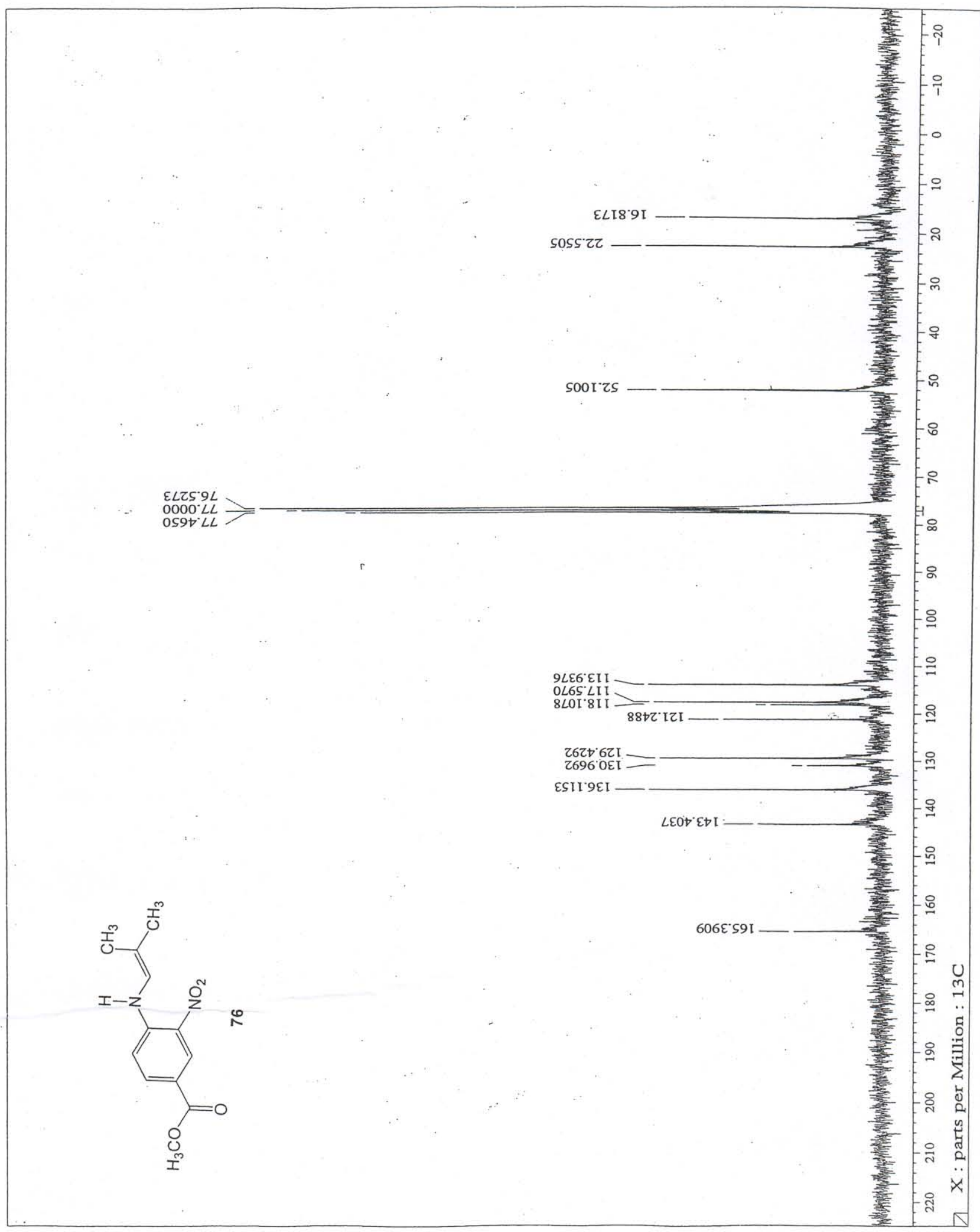

Figure 26: ${ }^{13} \mathrm{C}$ NMR of Compound 76 


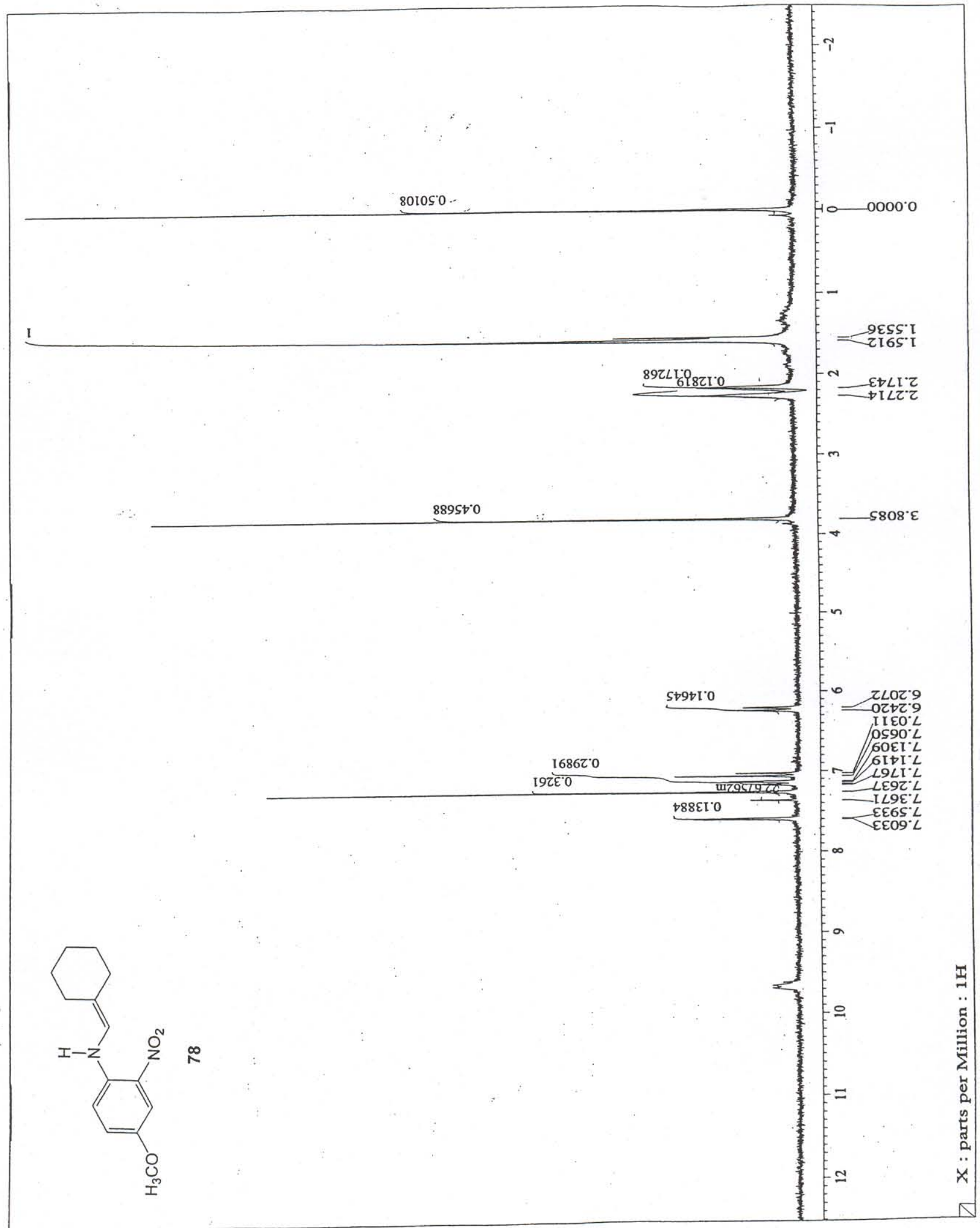

Figure 27: ${ }^{1} \mathrm{H}$ NMR of Compound 78 


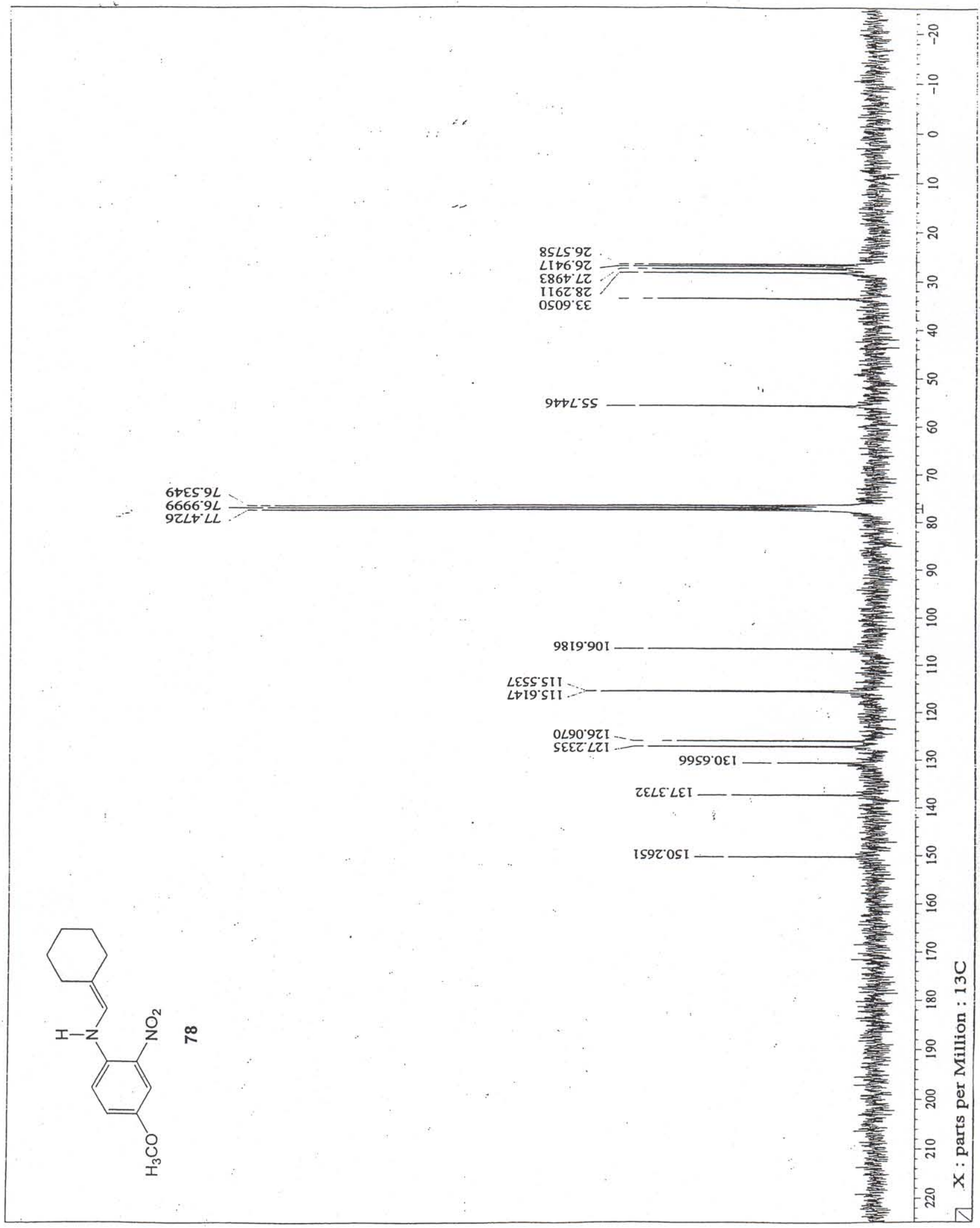

Figure 28: ${ }^{13} \mathrm{C}$ NMR of Compound 78 


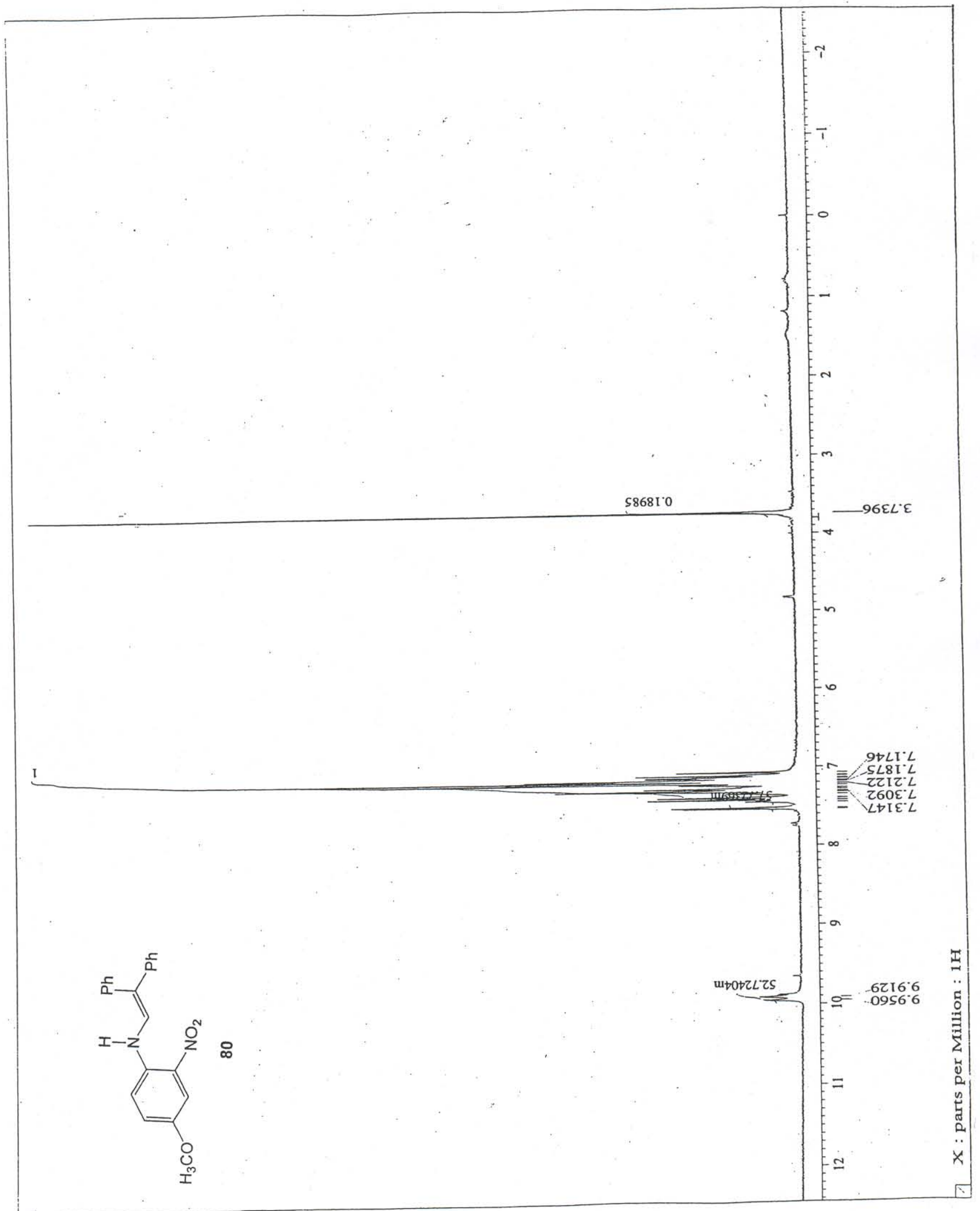

Figure 29: ${ }^{1} \mathrm{H}$ NMR of Compound 80 


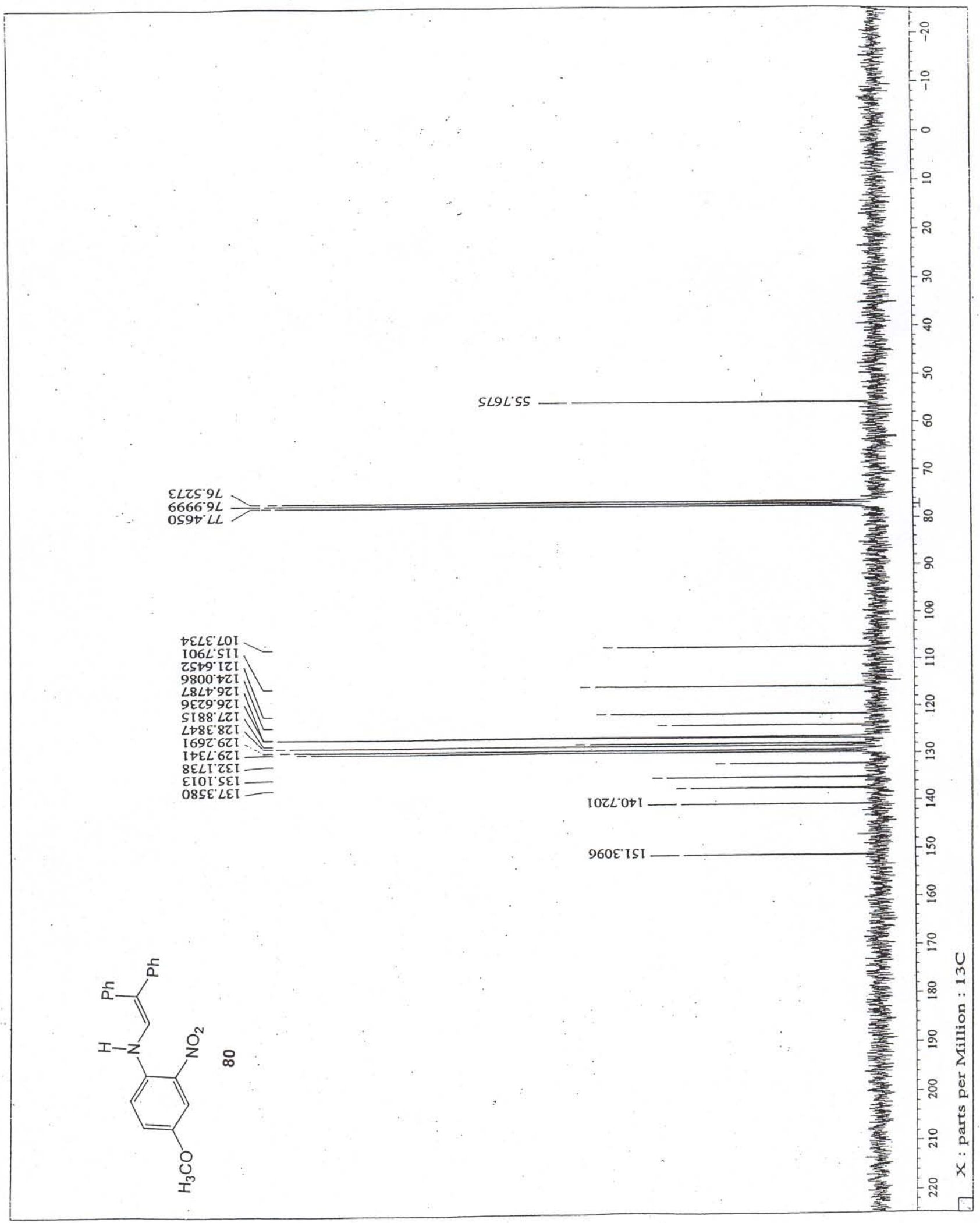

Figure $30:{ }^{13} \mathrm{C}$ NMR of Compound 80 


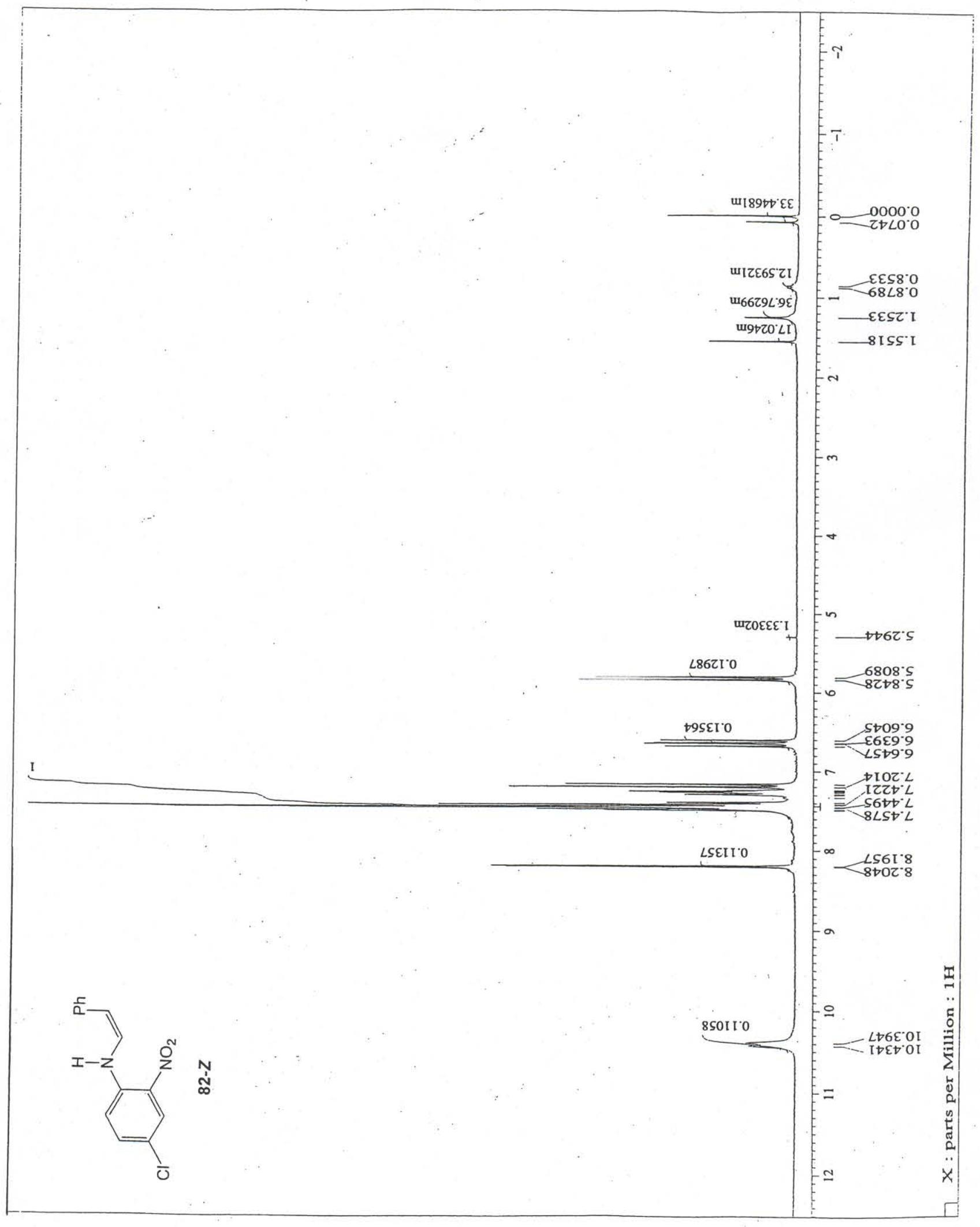

Figure 31: ${ }^{1} \mathrm{H}$ NMR of Compound $\mathbf{8 2 -} \boldsymbol{Z}$ 


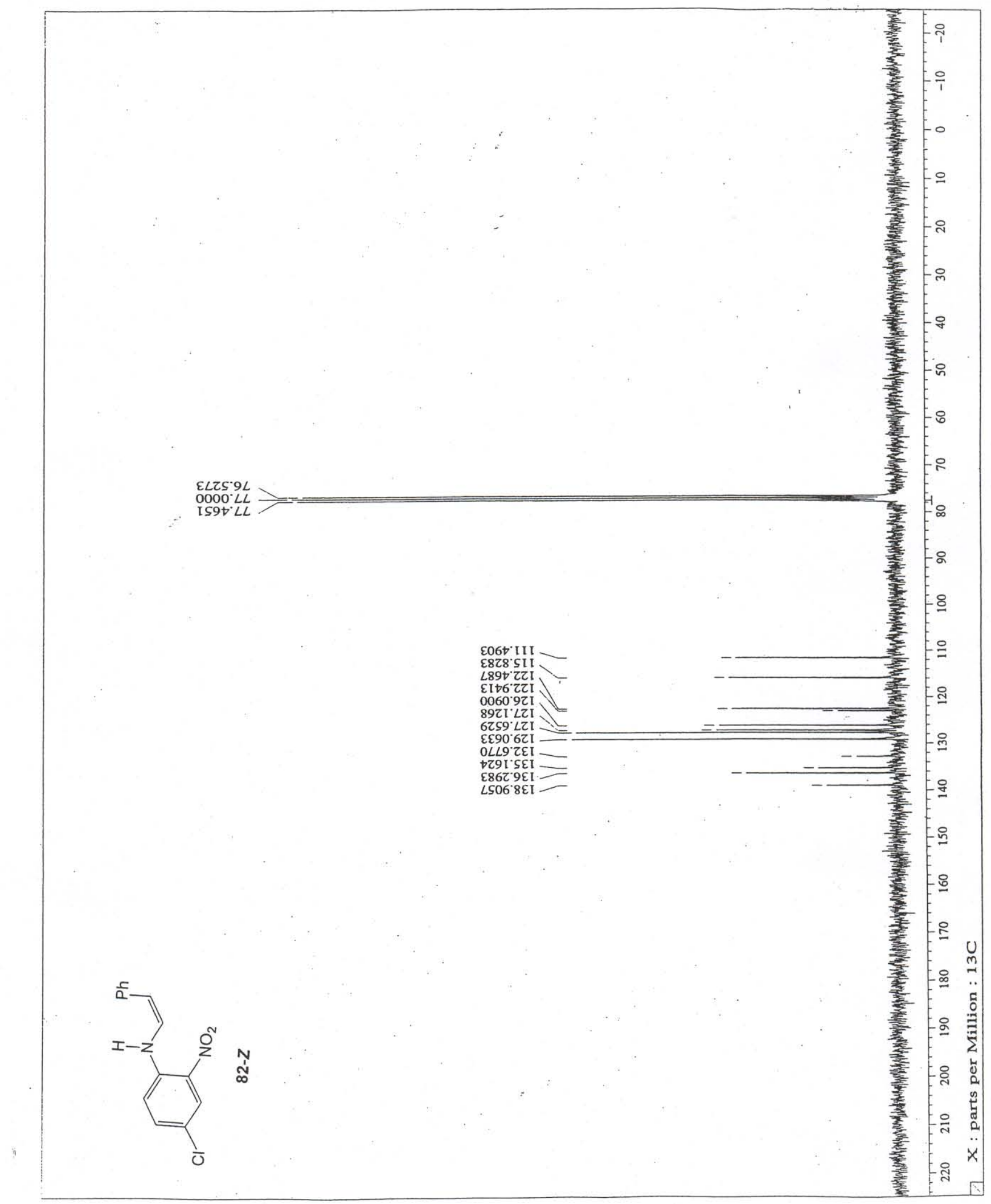

Figure 32: ${ }^{13} \mathrm{C}$ NMR of Compound $82-Z$ 


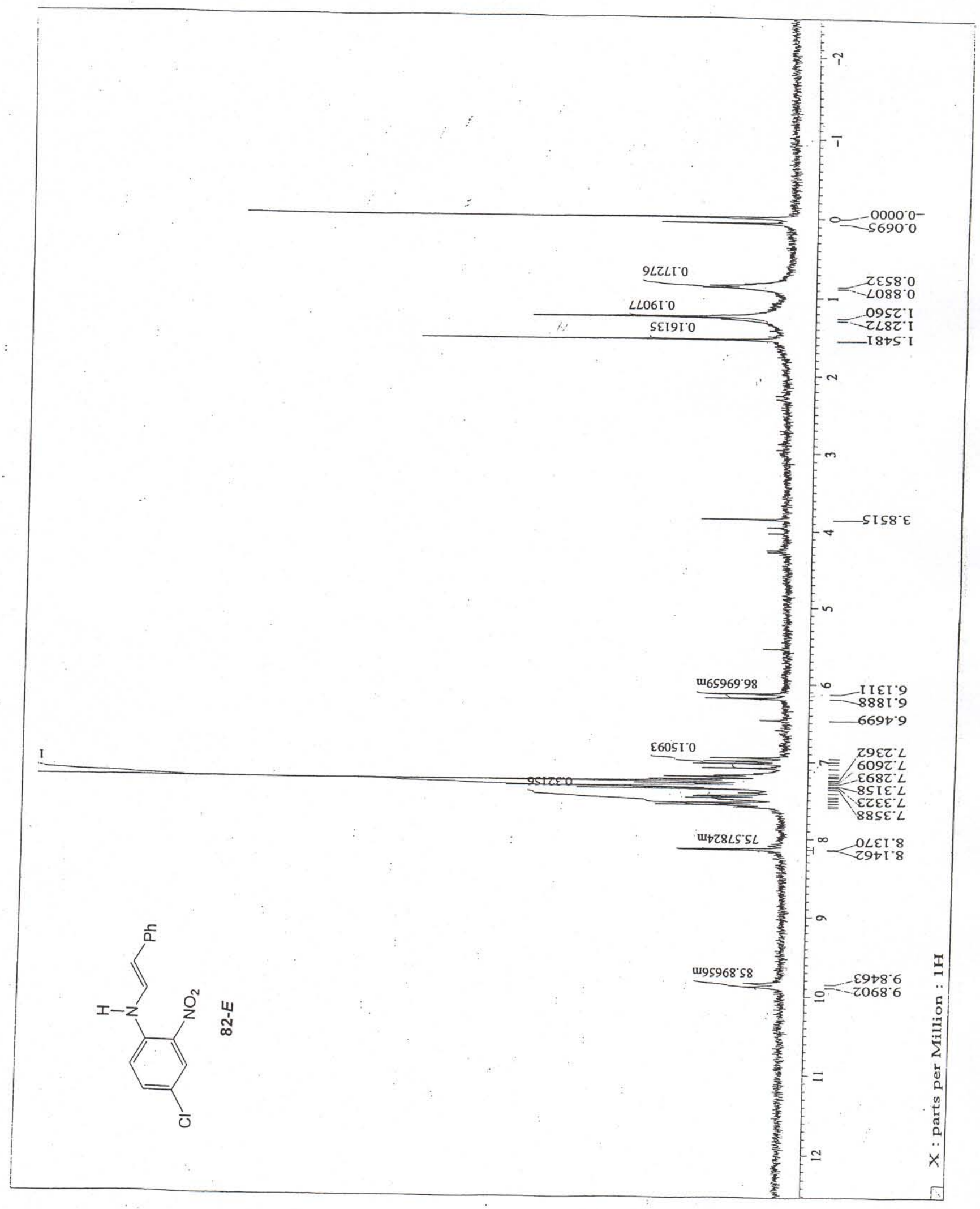

Figure 33: ${ }^{1} \mathrm{H}$ NMR of Compound 82-E 


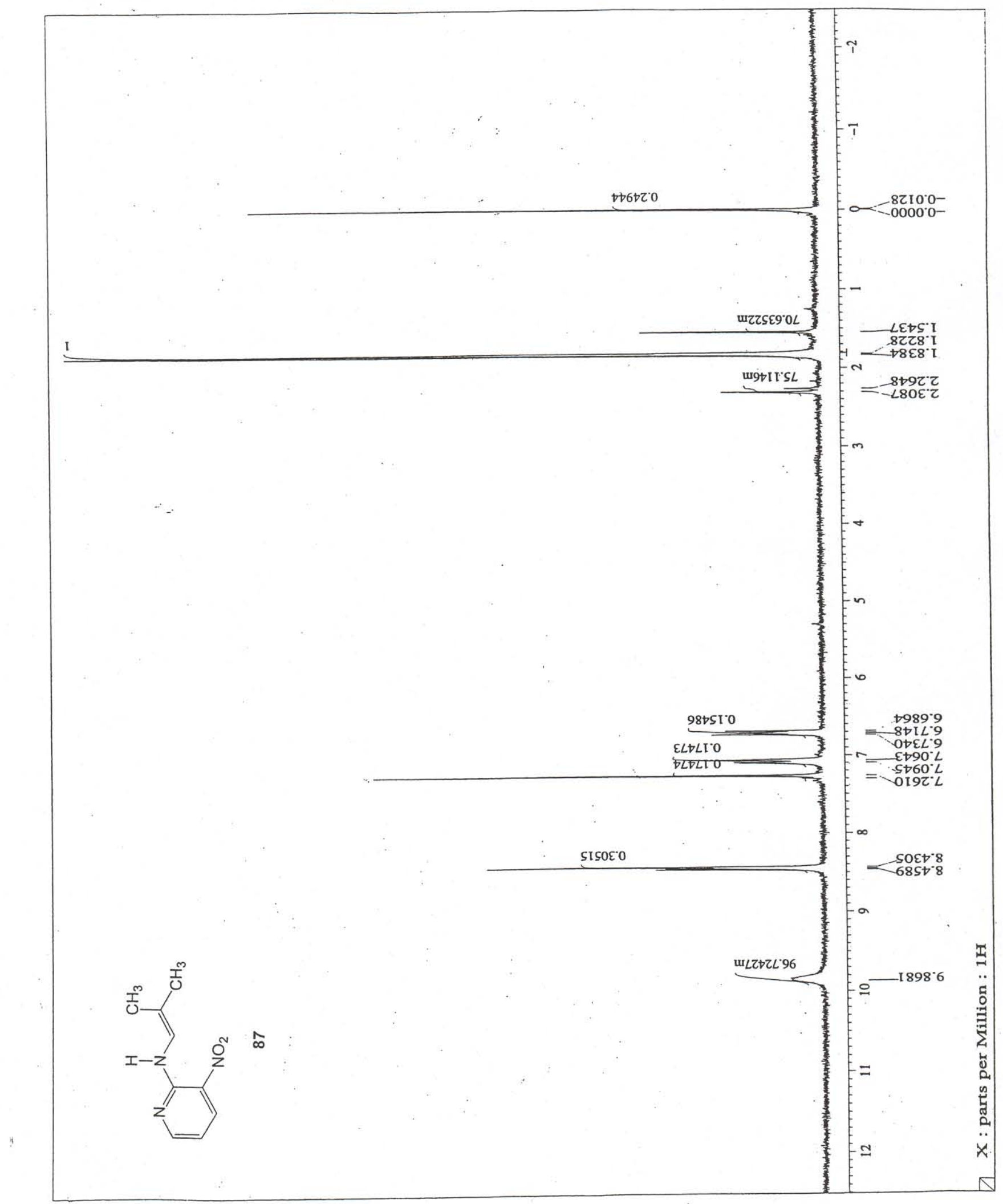

Figure 34: ${ }^{1} \mathrm{H}$ NMR of Compound 87 


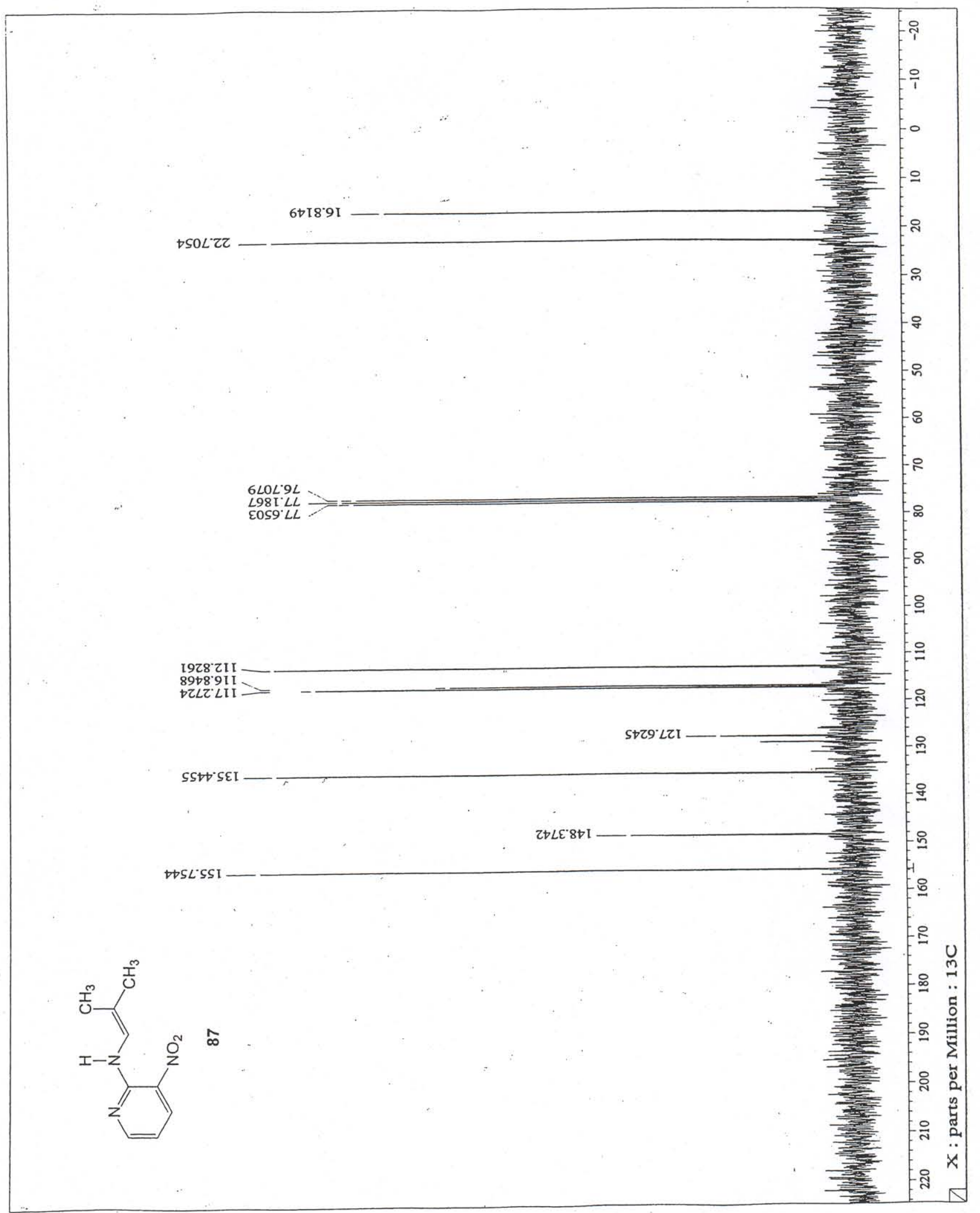

Figure 35: ${ }^{13} \mathrm{C}$ NMR of Compound 87 


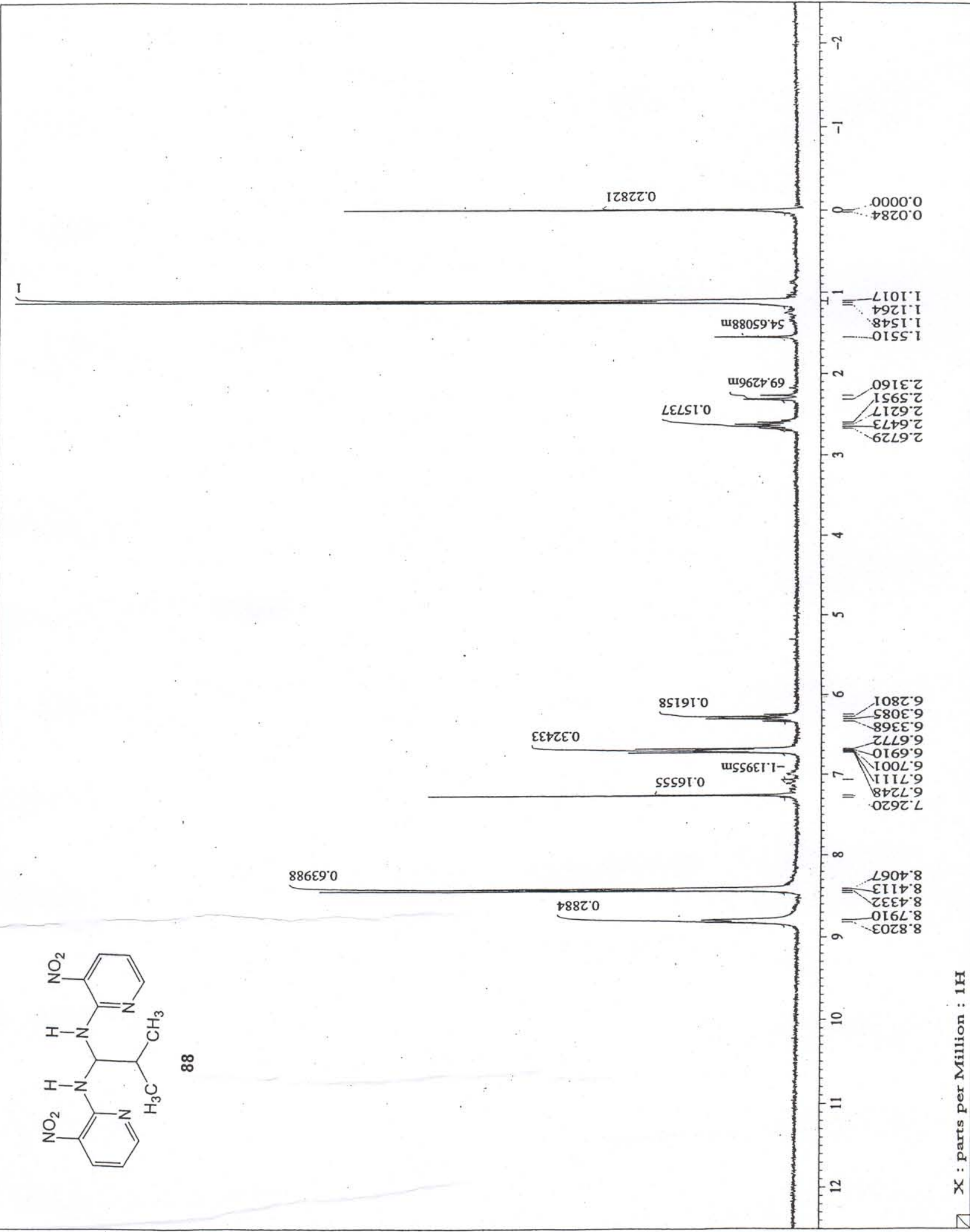

Figure 36: ${ }^{1} \mathrm{H}$ NMR of Compound $\mathbf{8 8}$ 


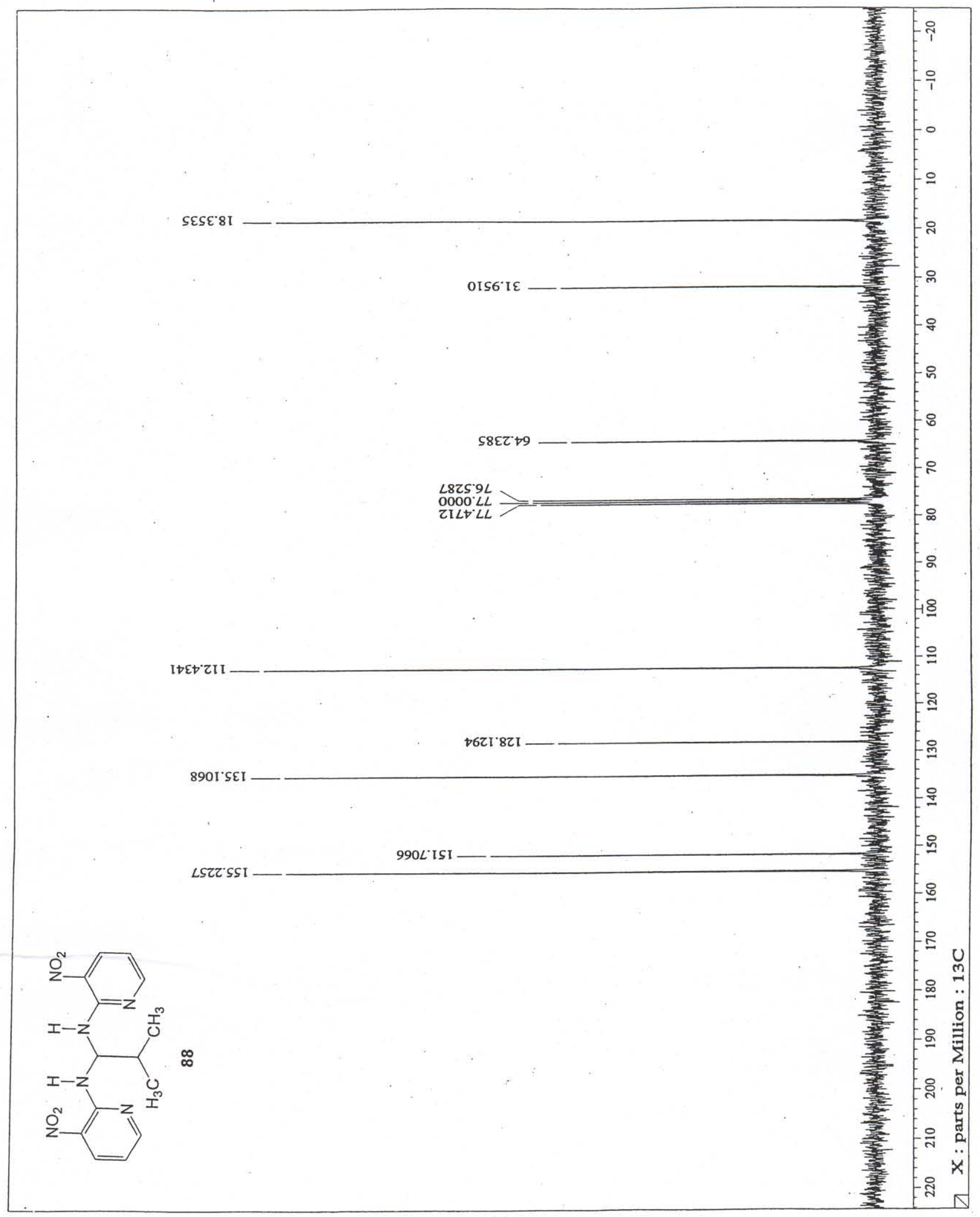

Figure 37: ${ }^{13} \mathrm{C}$ NMR of Compound 88 


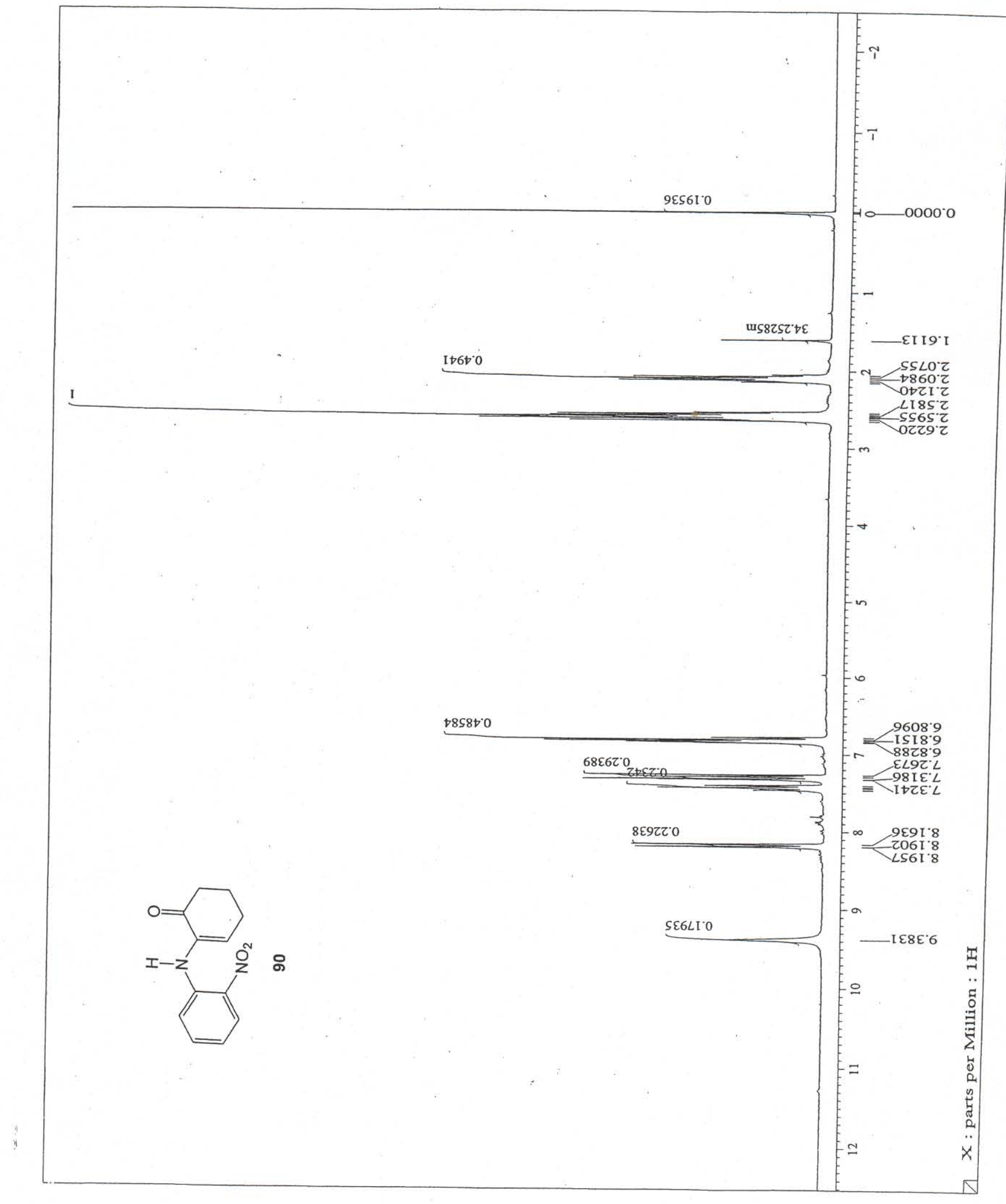

Figure 38: ${ }^{1} \mathrm{H}$ NMR of Compound 90 


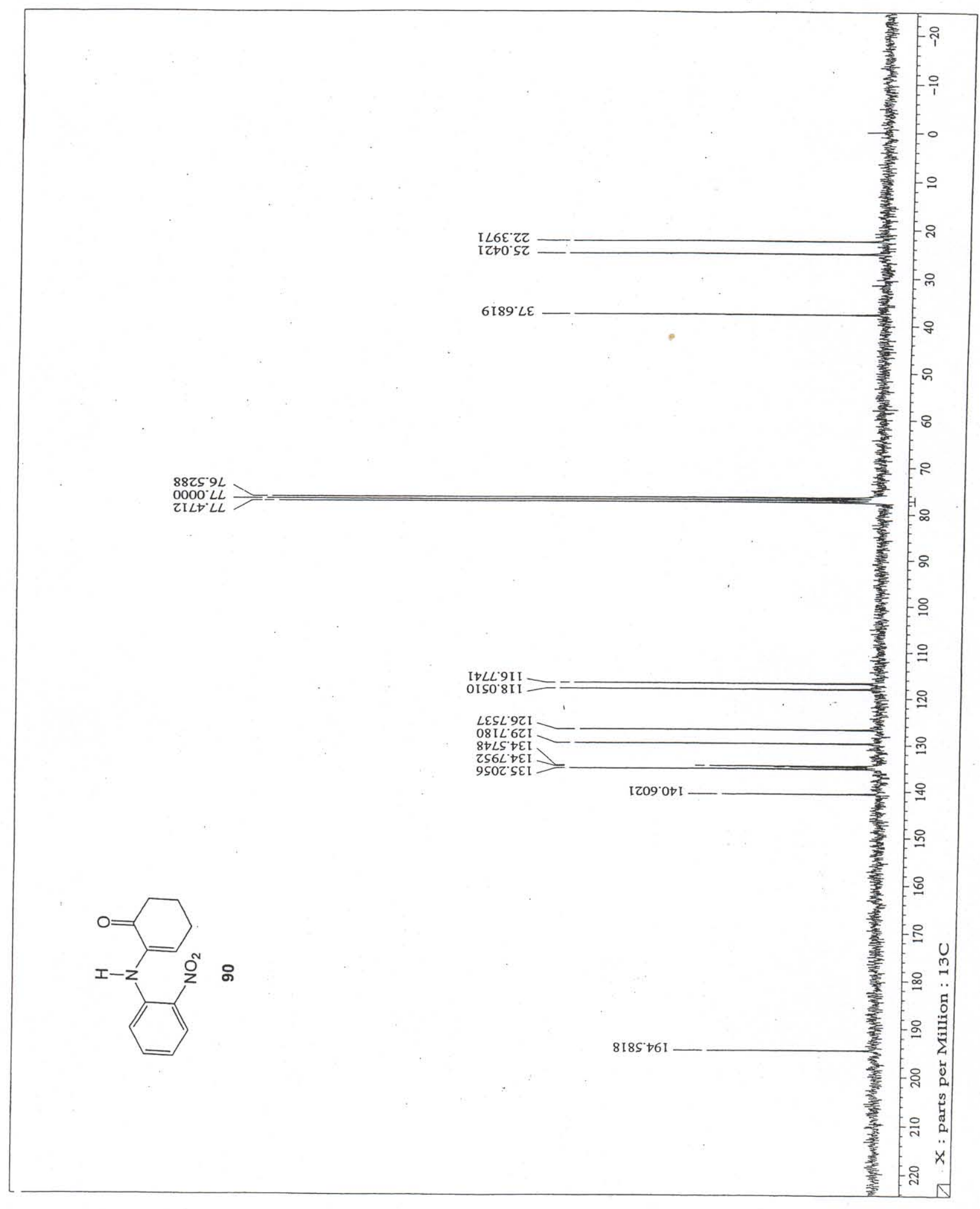

Figure 39: ${ }^{13} \mathrm{C}$ NMR of Compound 90 


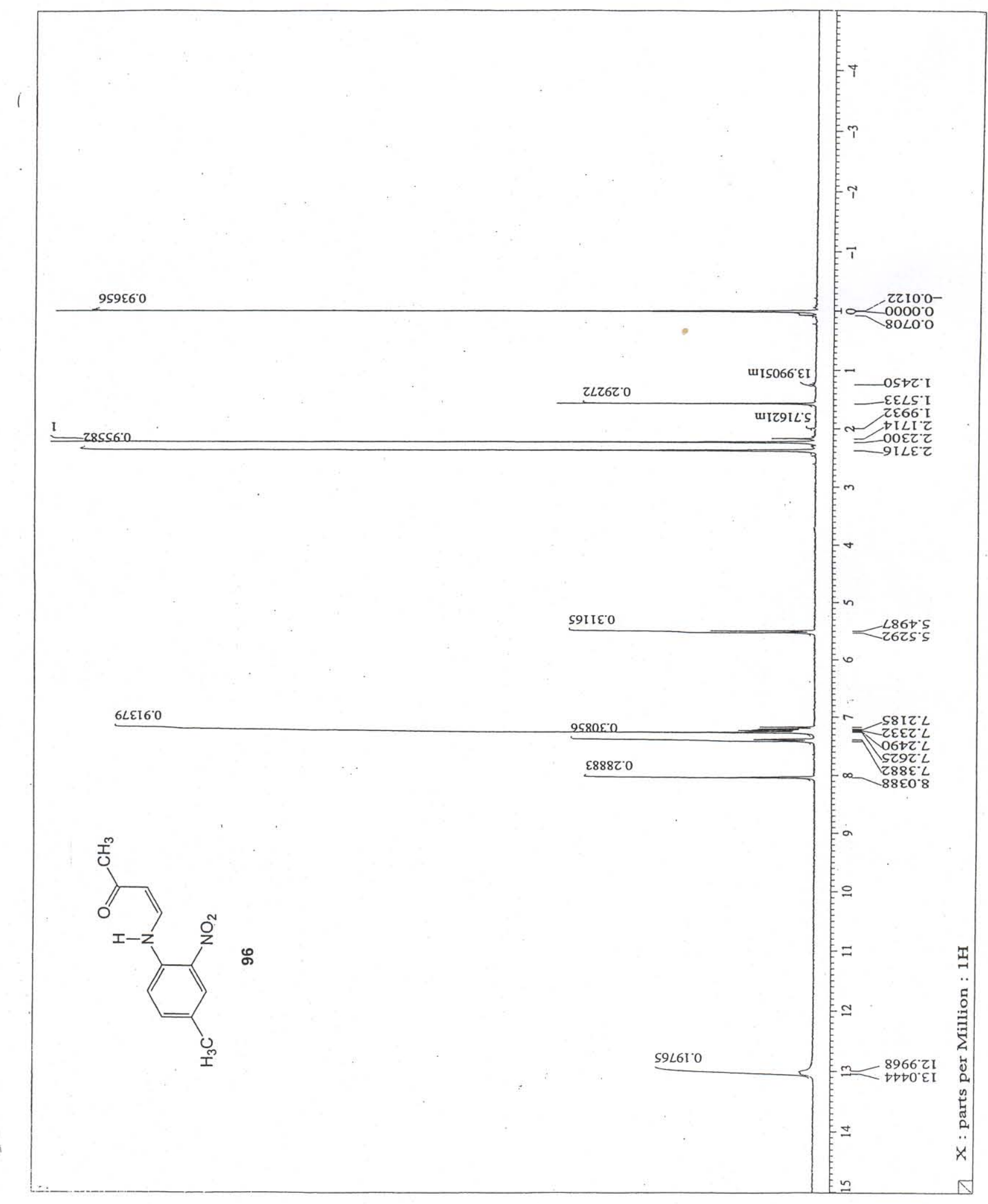

Figure 40: ${ }^{1} \mathrm{H}$ NMR of Compound 96 


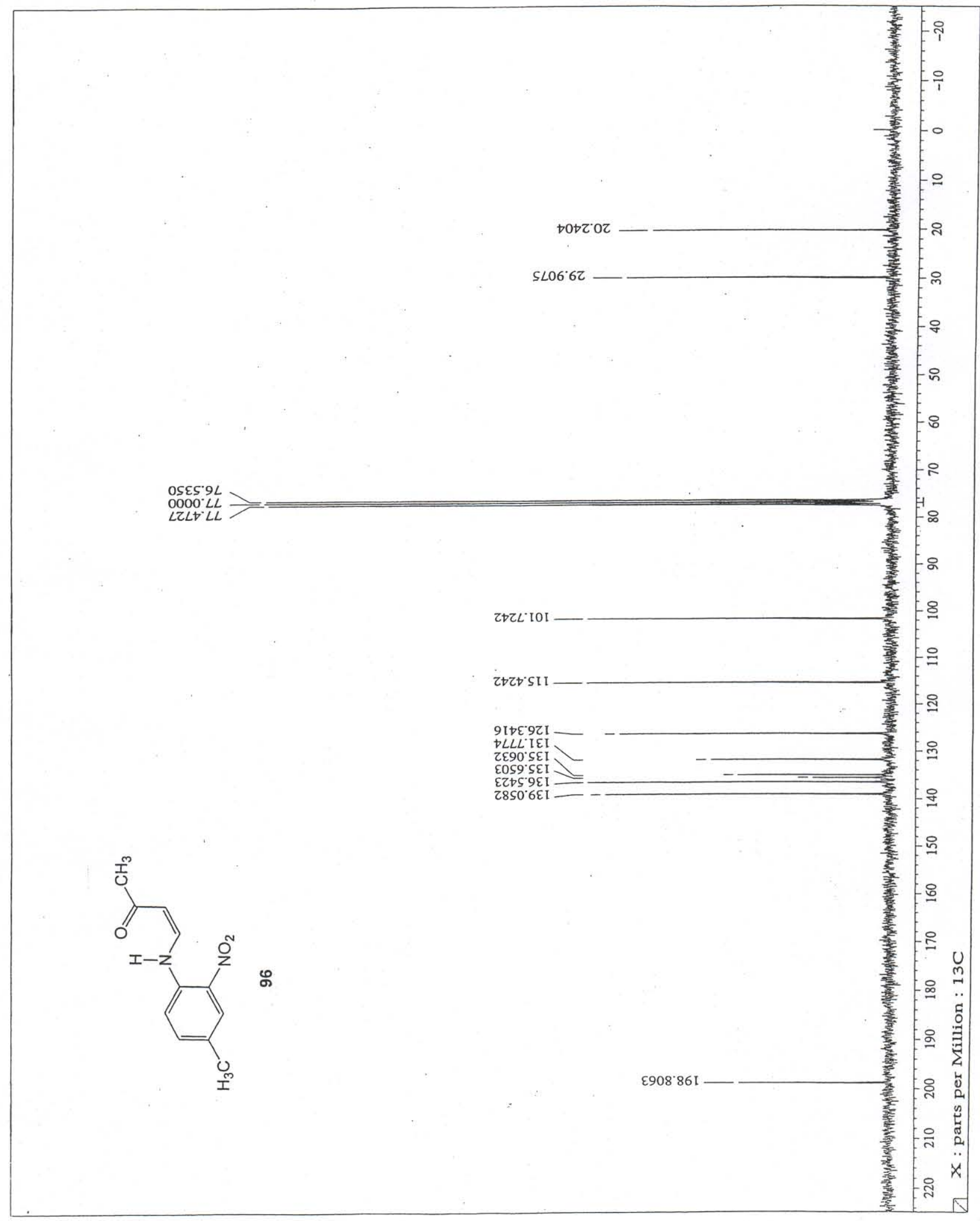

Figure 41: ${ }^{13} \mathrm{C}$ NMR of Compound 96 


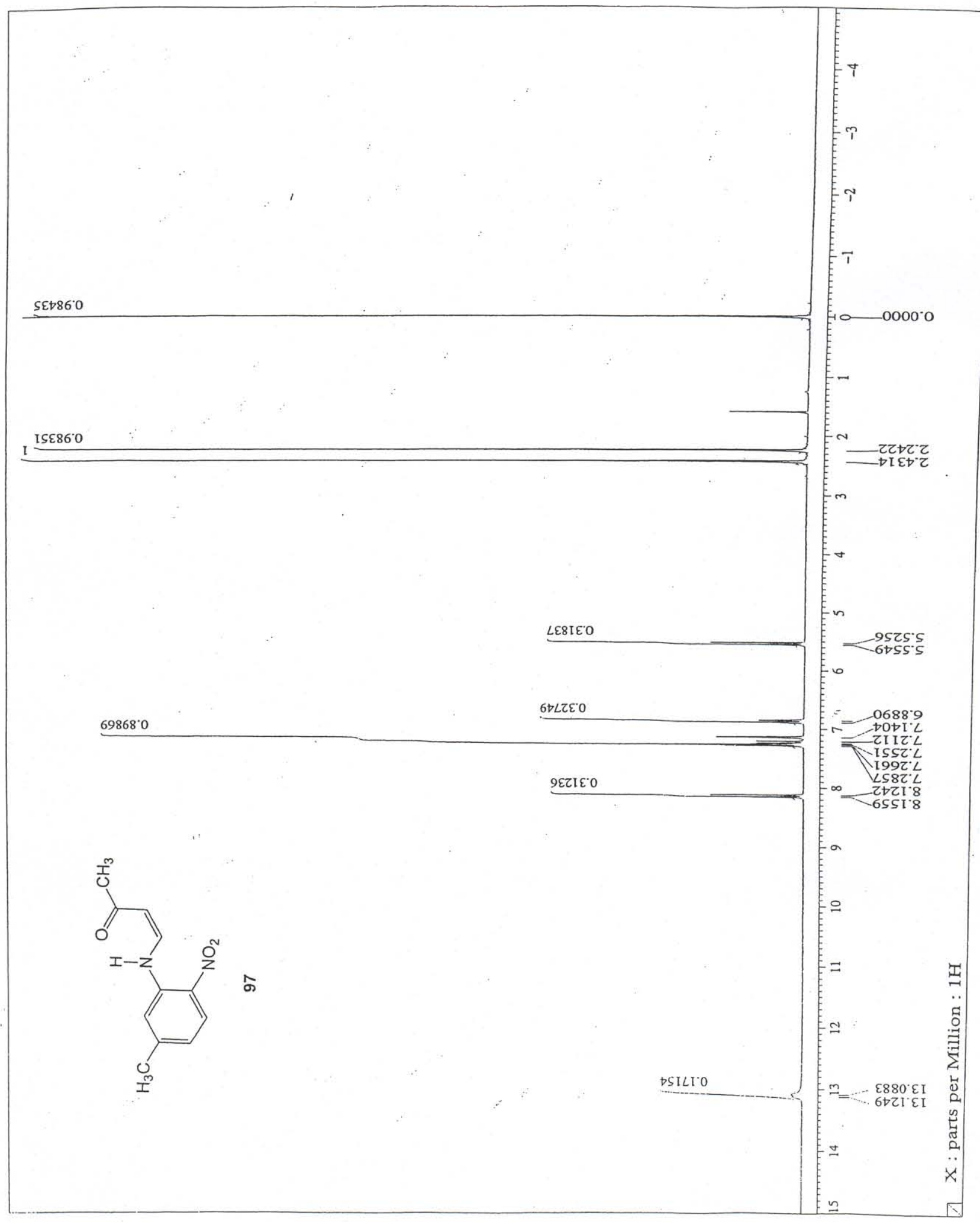

Figure 42: ${ }^{1} \mathrm{H}$ NMR of Compound 97 


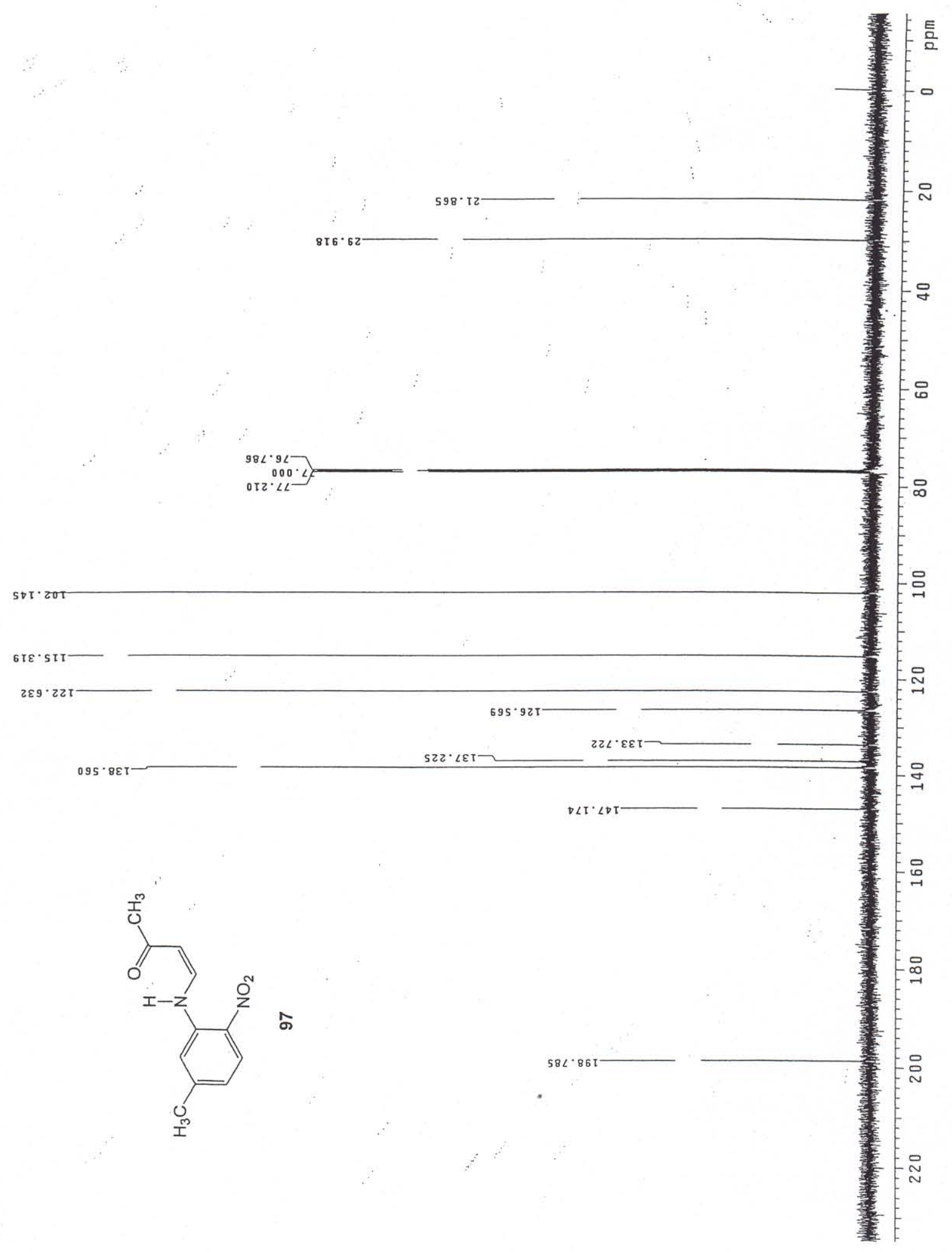

Figure 43: ${ }^{13} \mathrm{C}$ NMR of Compound 97 


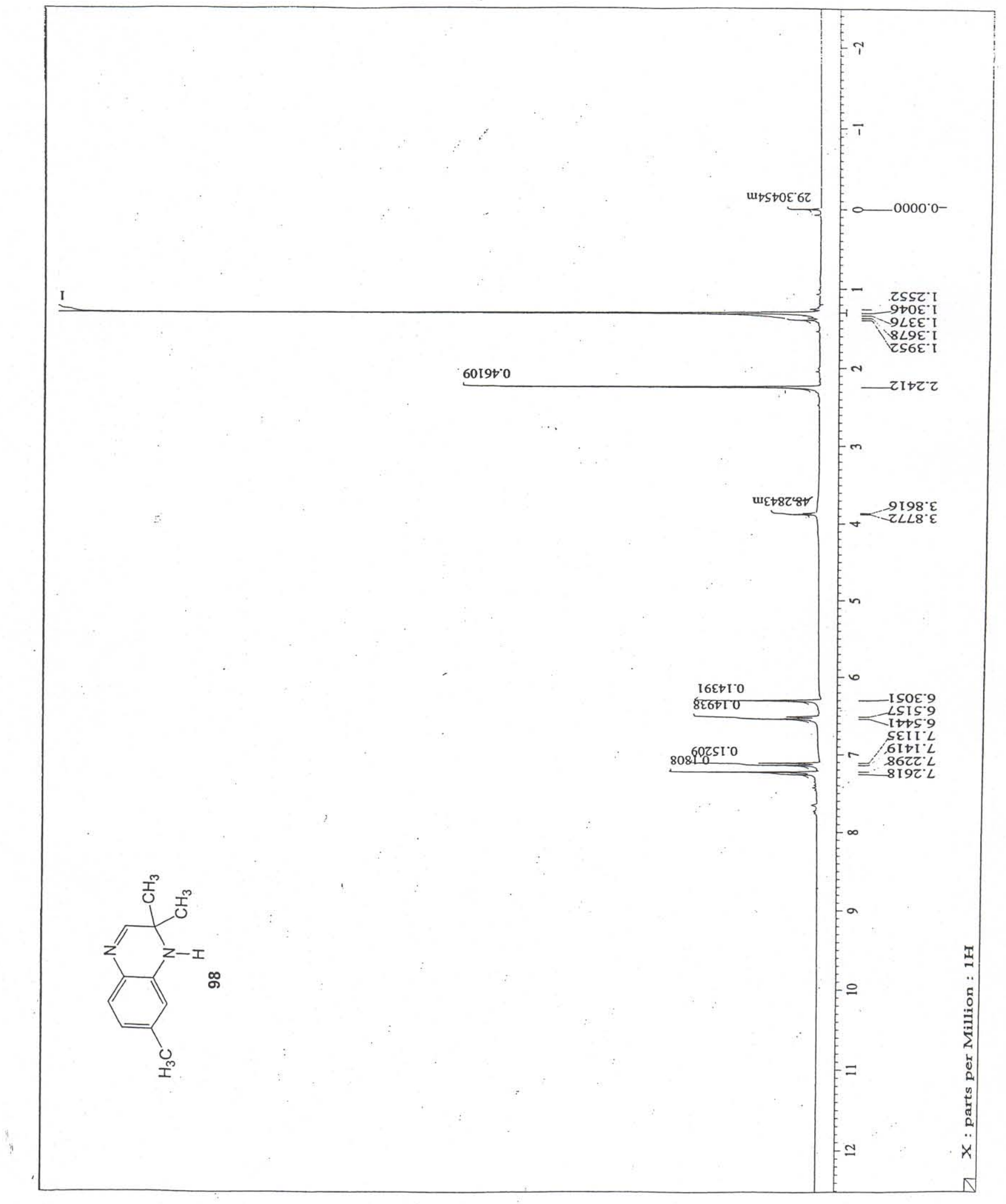

Figure 44: ${ }^{1} \mathrm{H}$ NMR of Compound 98 


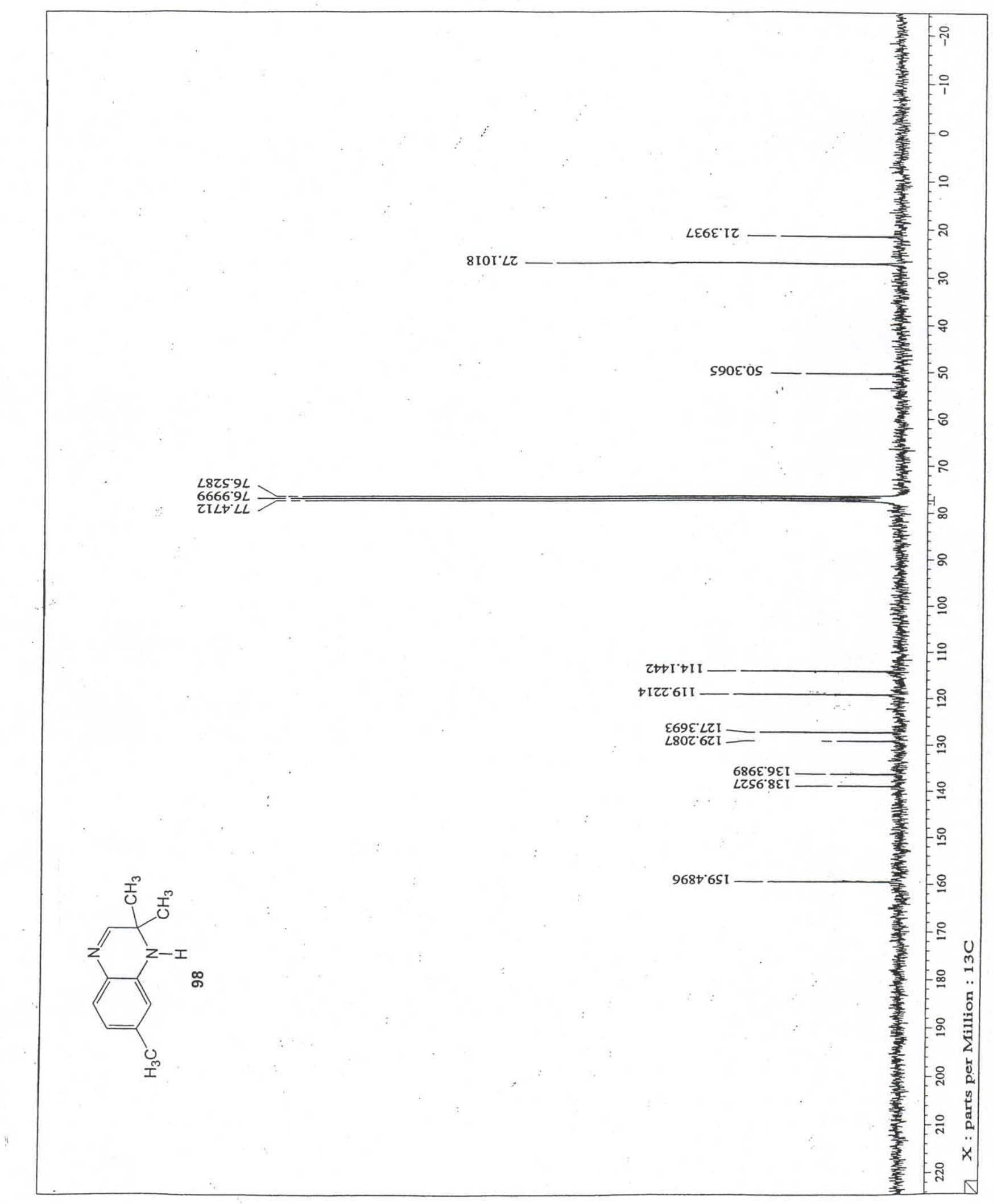

Figure 45: ${ }^{13} \mathrm{C}$ NMR of Compound 98 


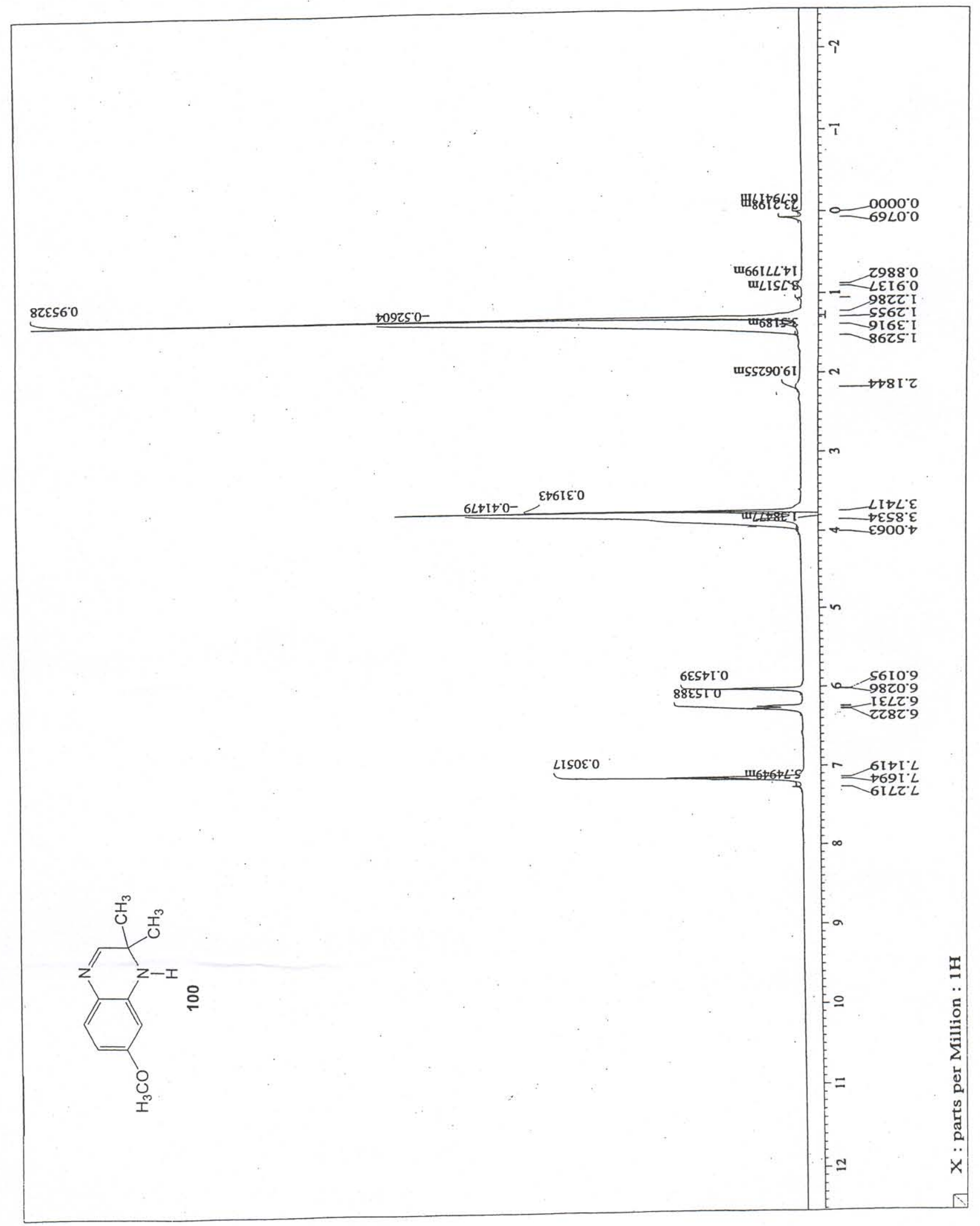

Figure 46: ${ }^{1} \mathrm{H}$ NMR of Compound 100 


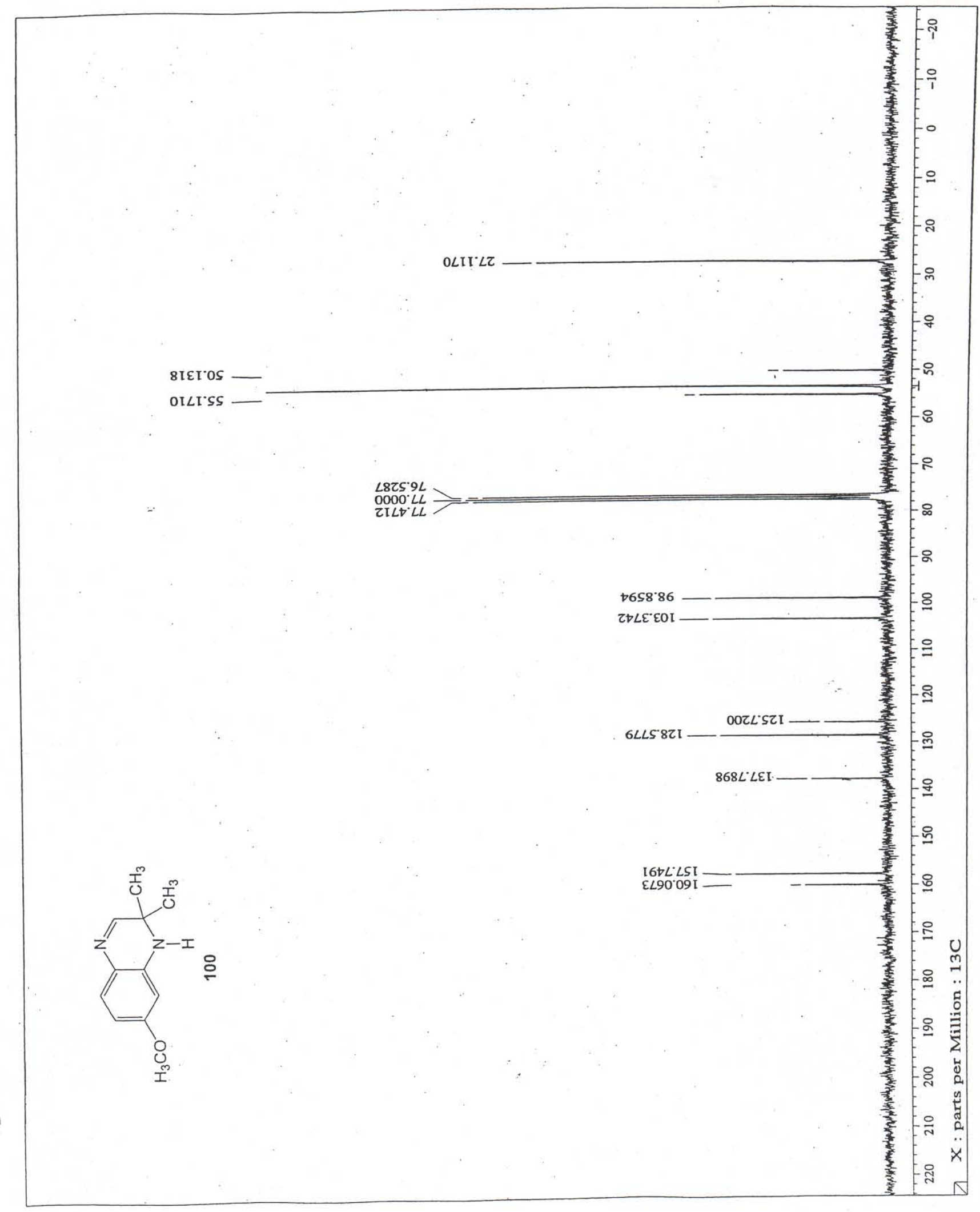

Figure 47: ${ }^{13} \mathrm{C}$ NMR of Compound 100 


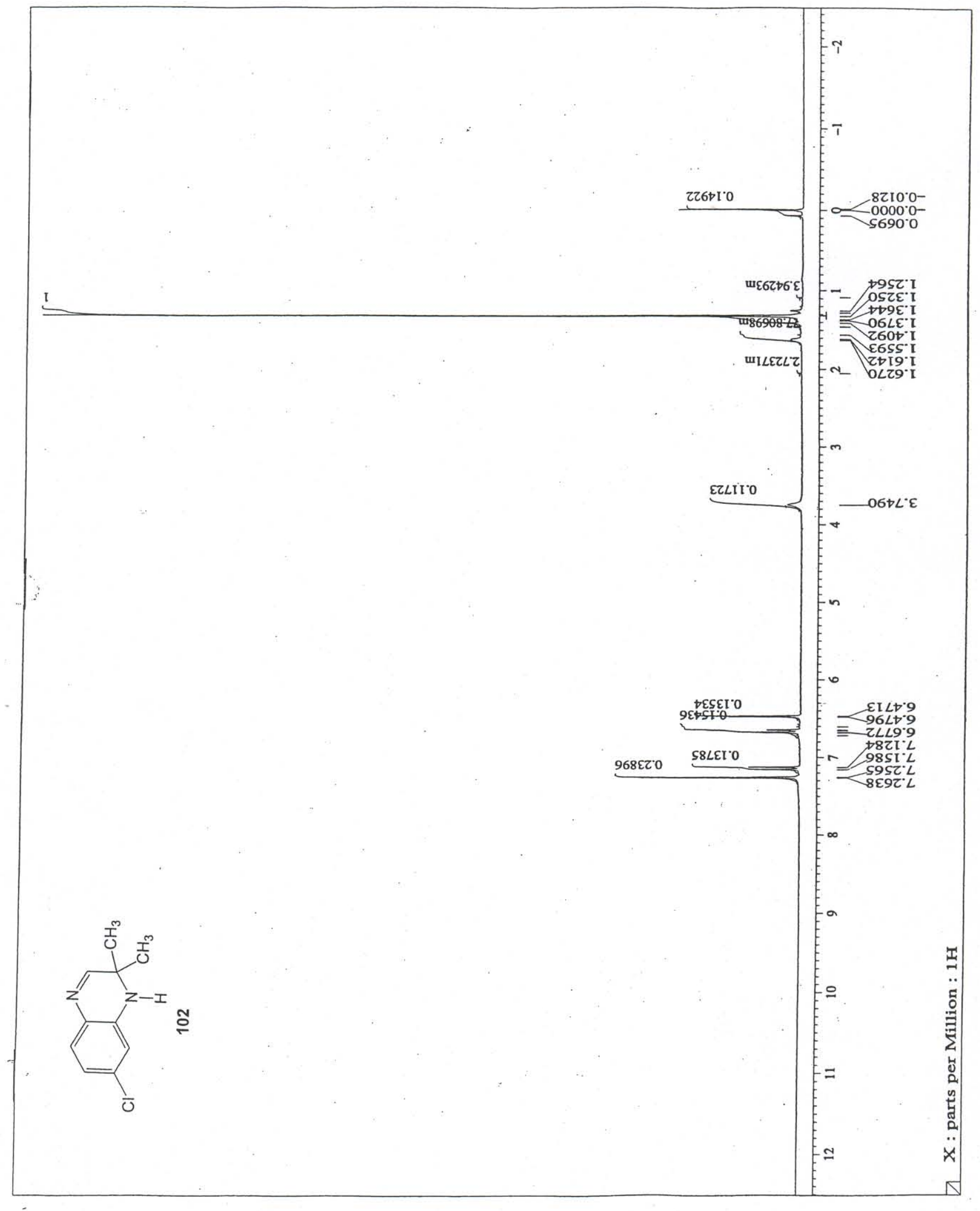

Figure 48: ${ }^{1} \mathrm{H}$ NMR of Compound $\mathbf{1 0 2}$ 


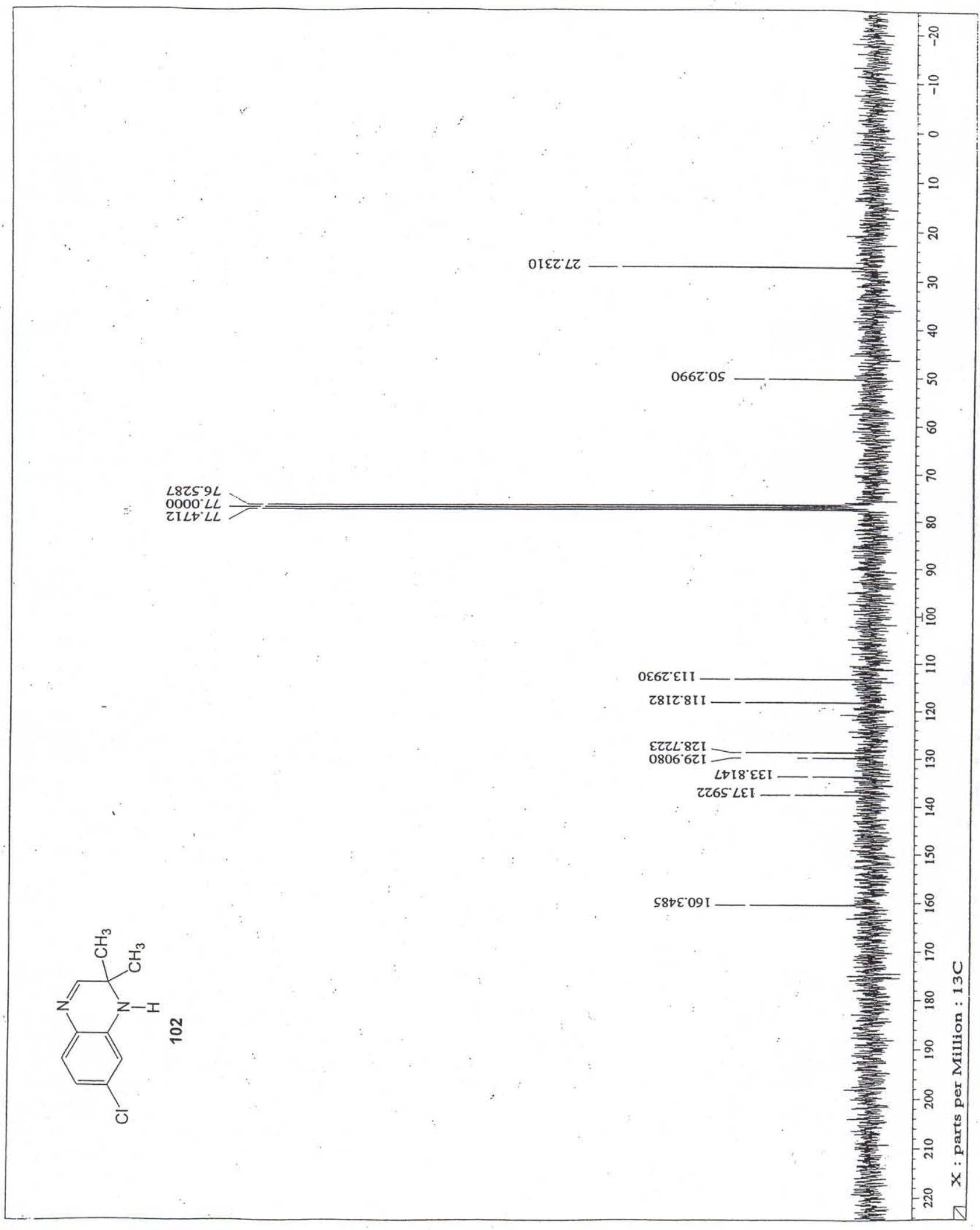

Figure 49: ${ }^{13} \mathrm{C}$ NMR of Compound 102 


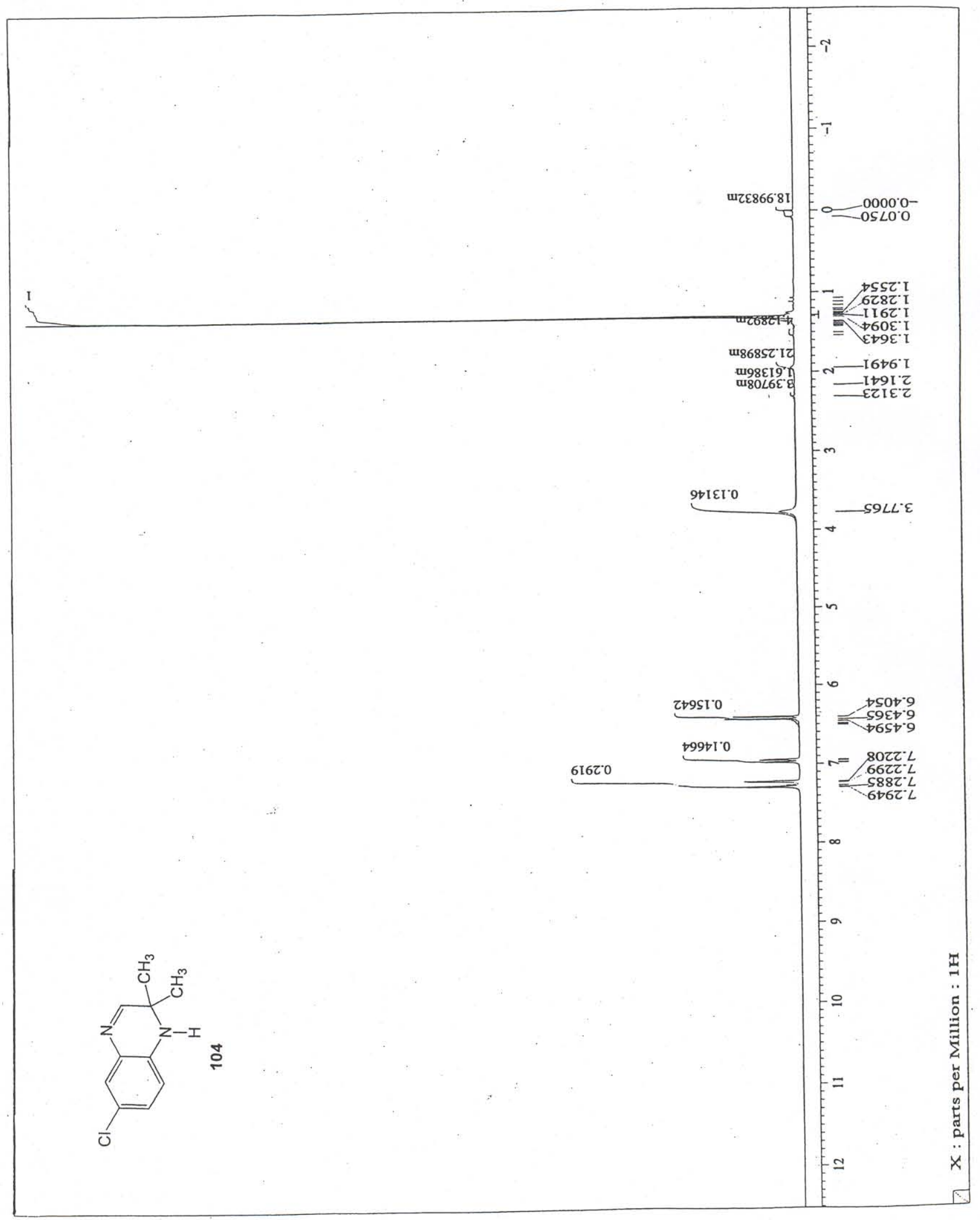

Figure 50: ${ }^{1} \mathrm{H}$ NMR of Compound 104 


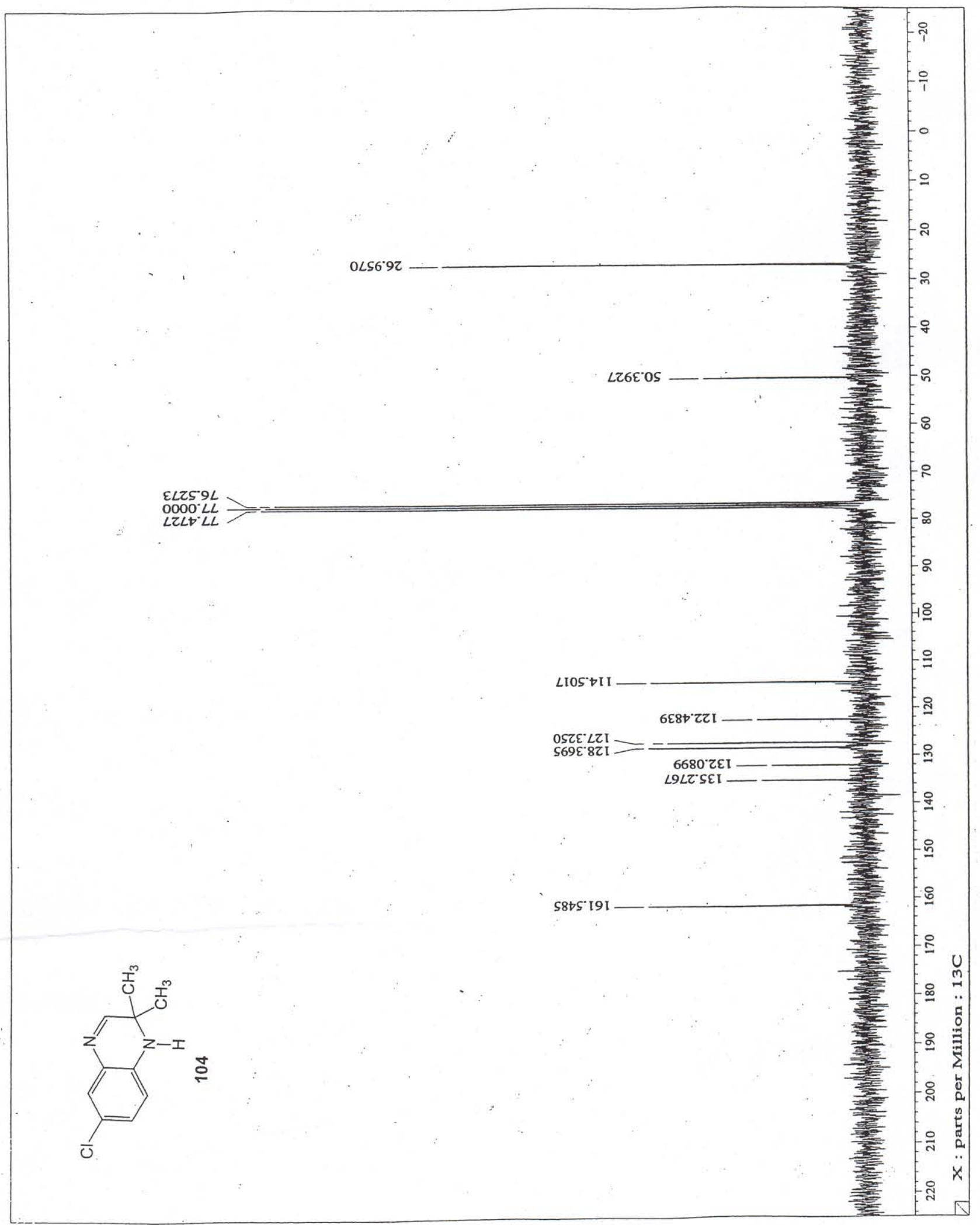

Figure 51: ${ }^{13} \mathrm{C}$ NMR of Compound 104 


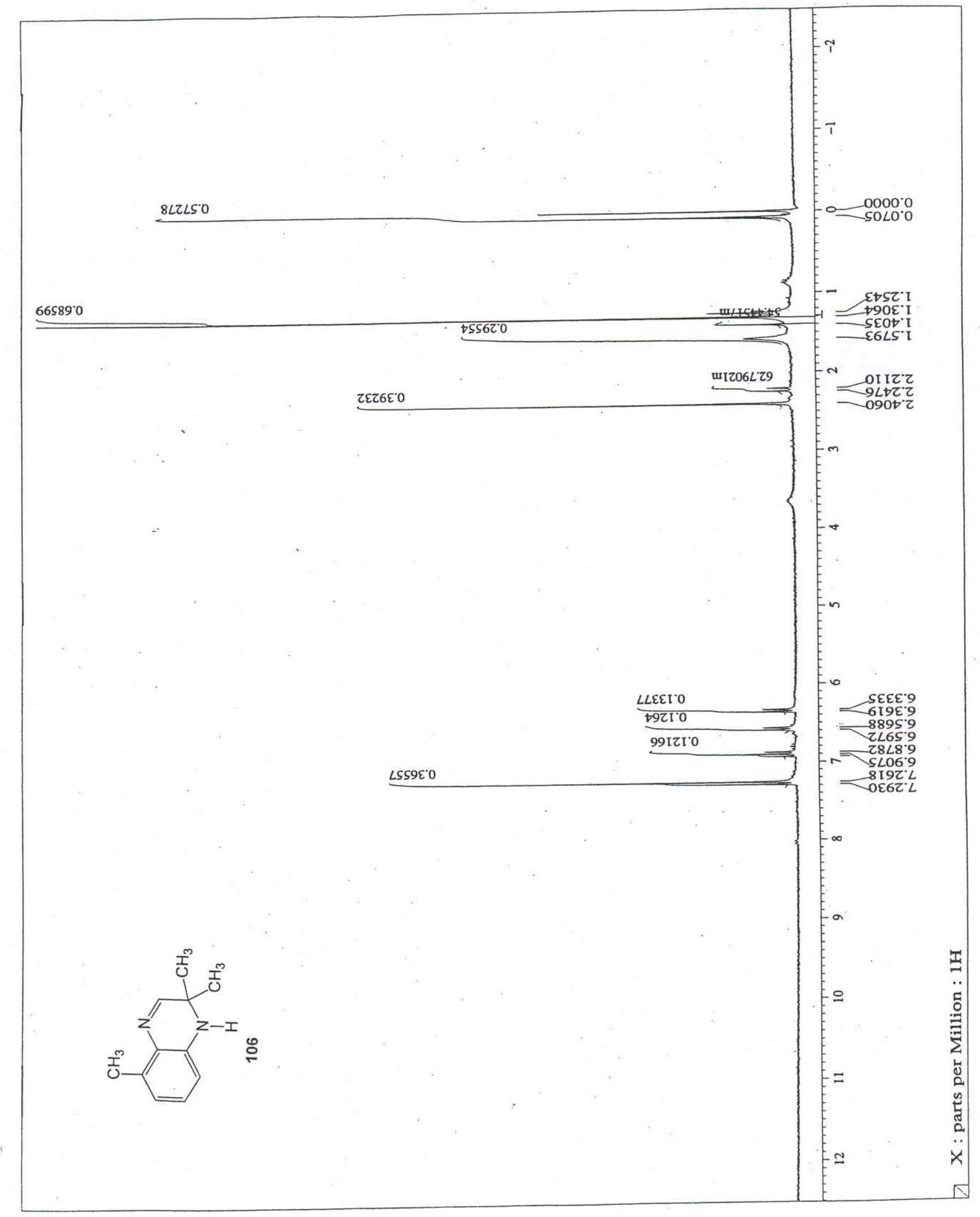

Figure 52: ${ }^{1} \mathrm{H}$ NMR of Compound 106 


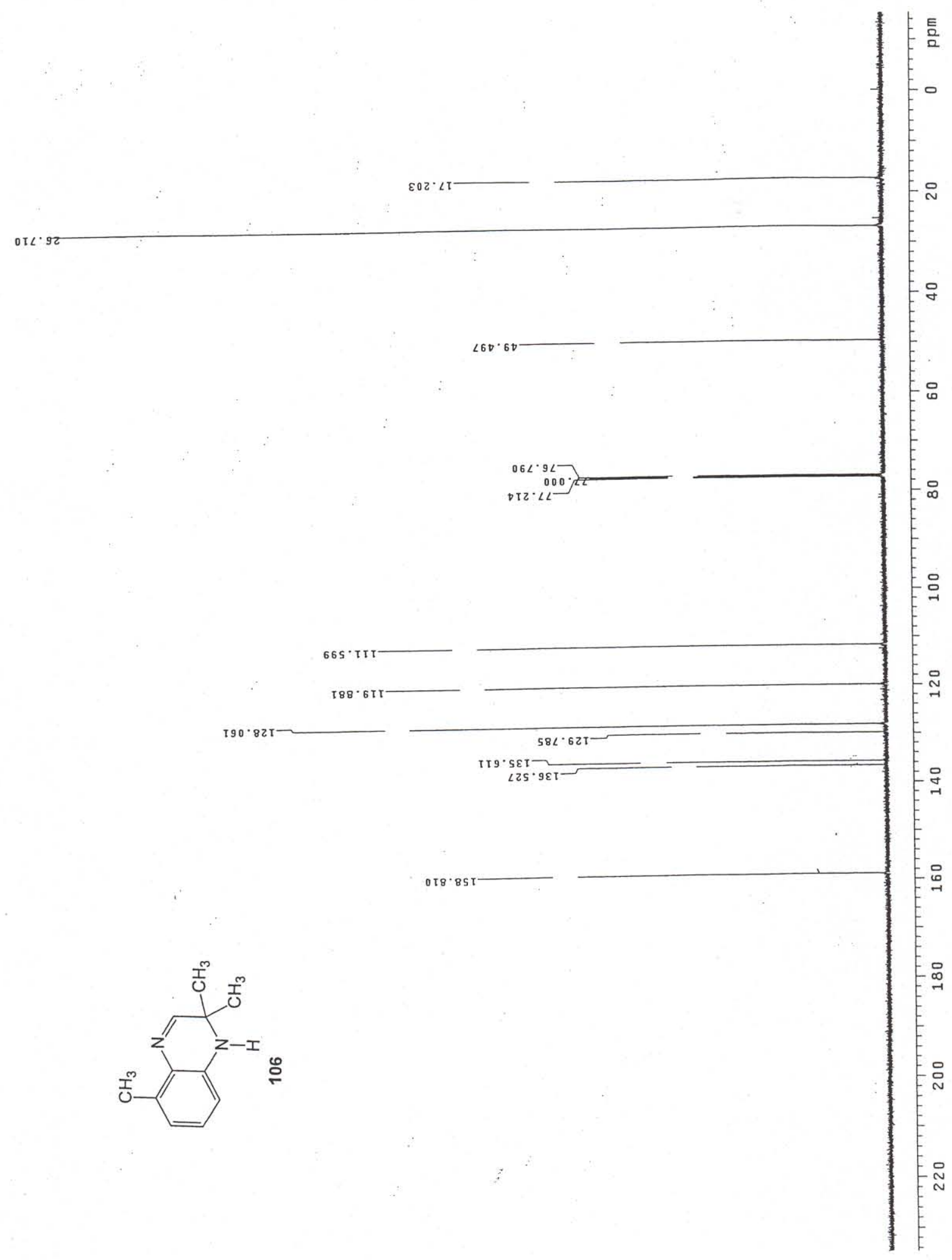

Figure 53: ${ }^{13} \mathrm{C}$ NMR of Compound 106 


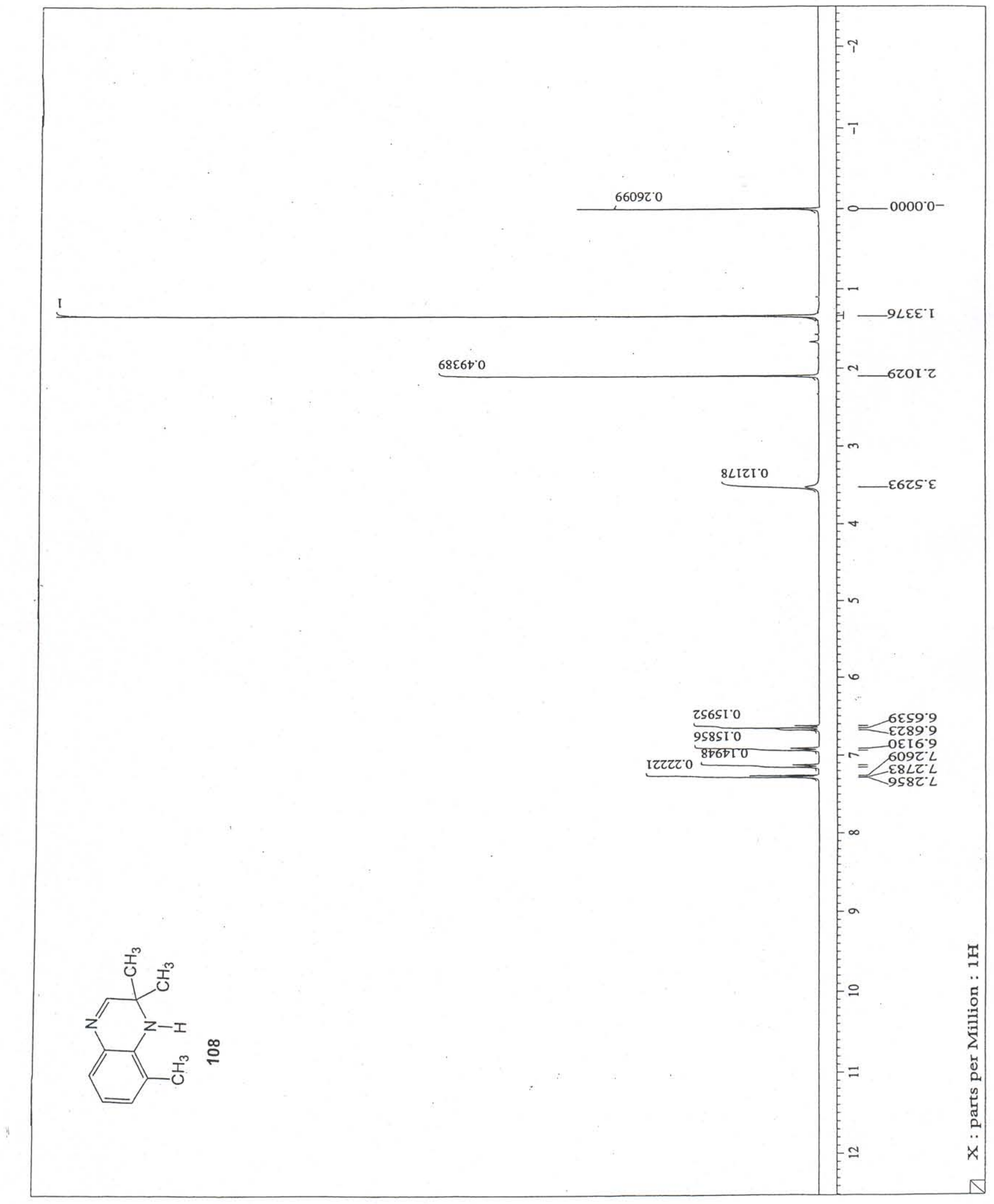

Figure 54: ${ }^{1} \mathrm{H}$ NMR of Compound $\mathbf{1 0 8}$ 


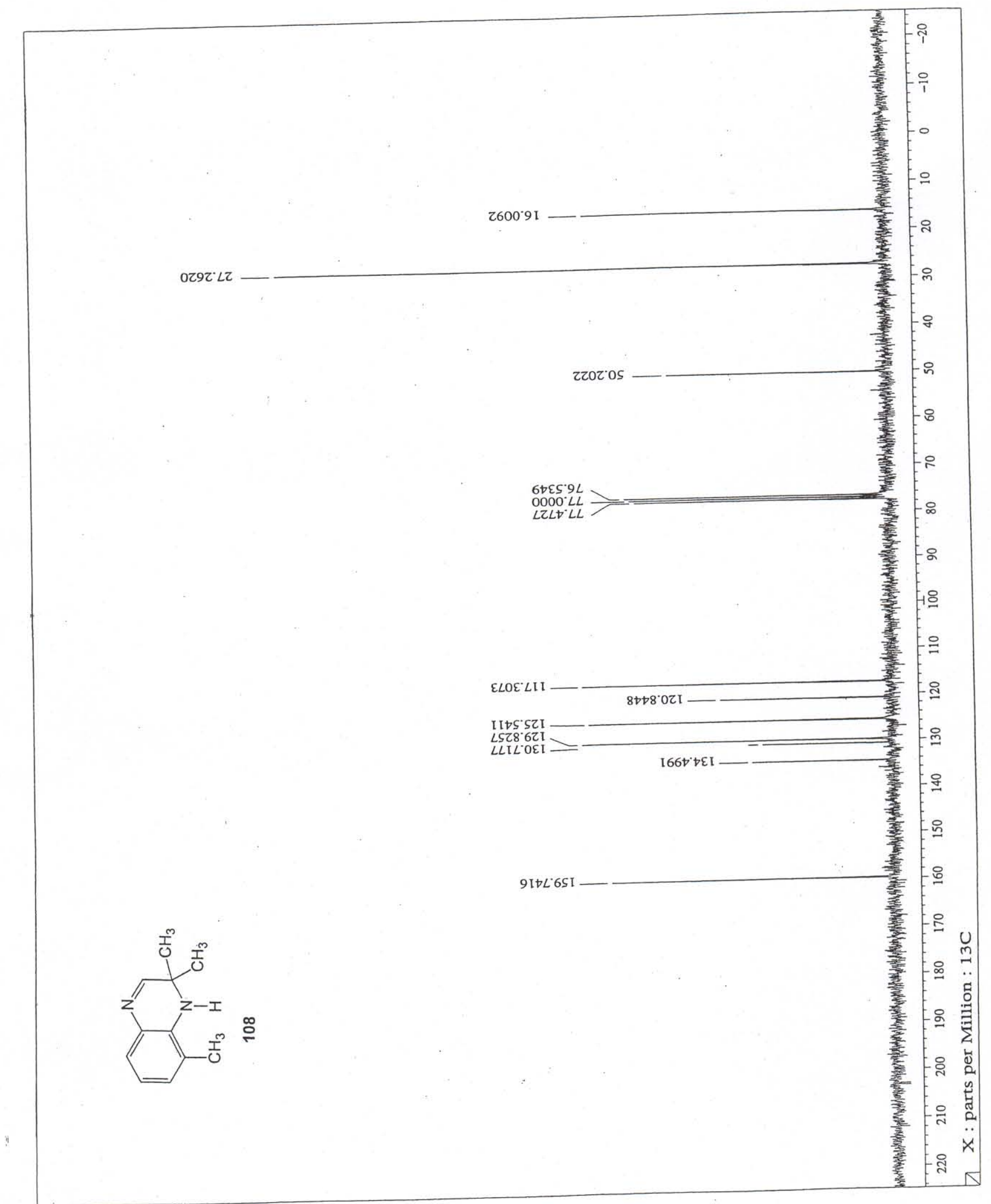

Figure 55: ${ }^{13} \mathrm{C}$ NMR of Compound 108 


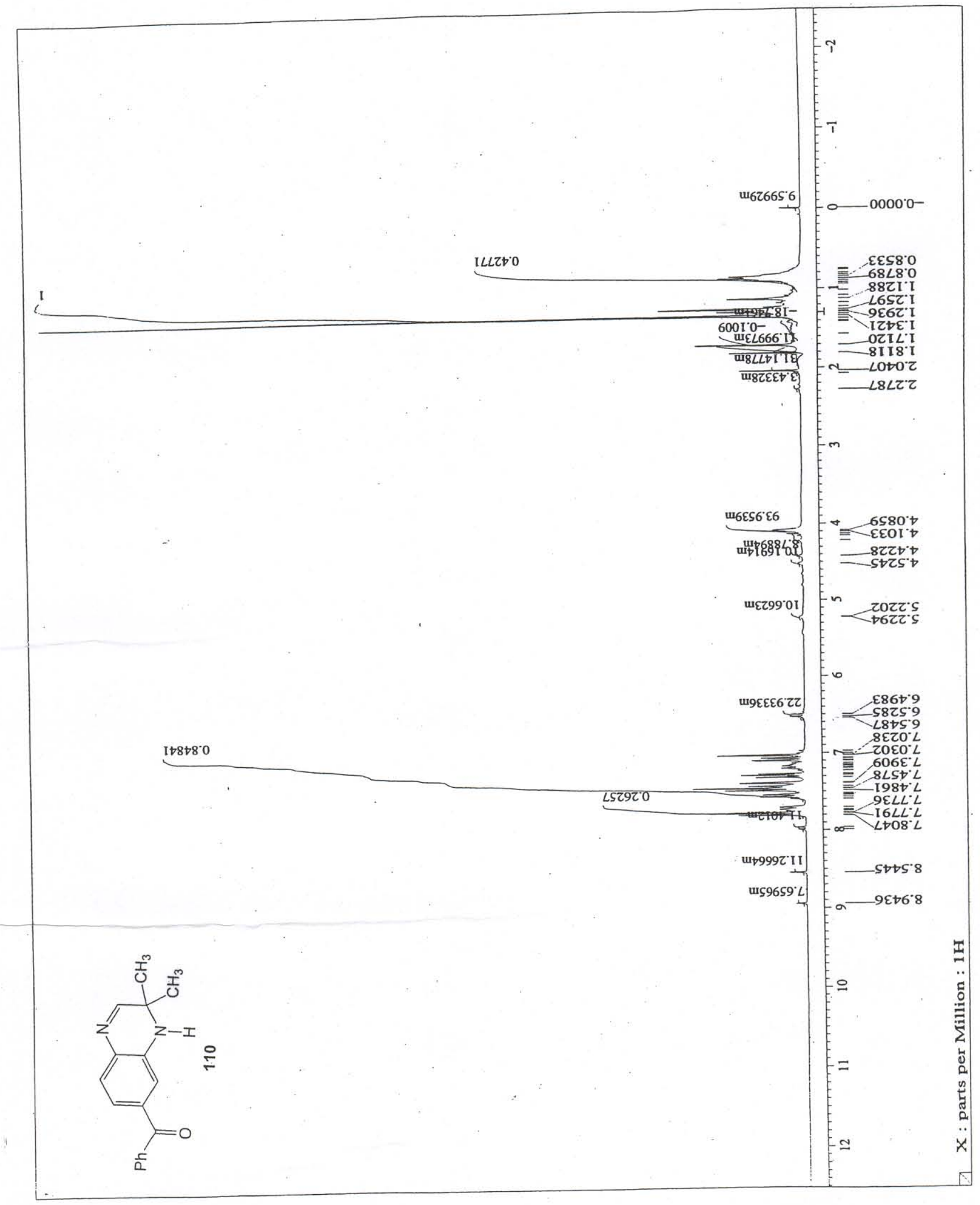

Figure 56: ${ }^{1} \mathrm{H}$ NMR of Compound 110 


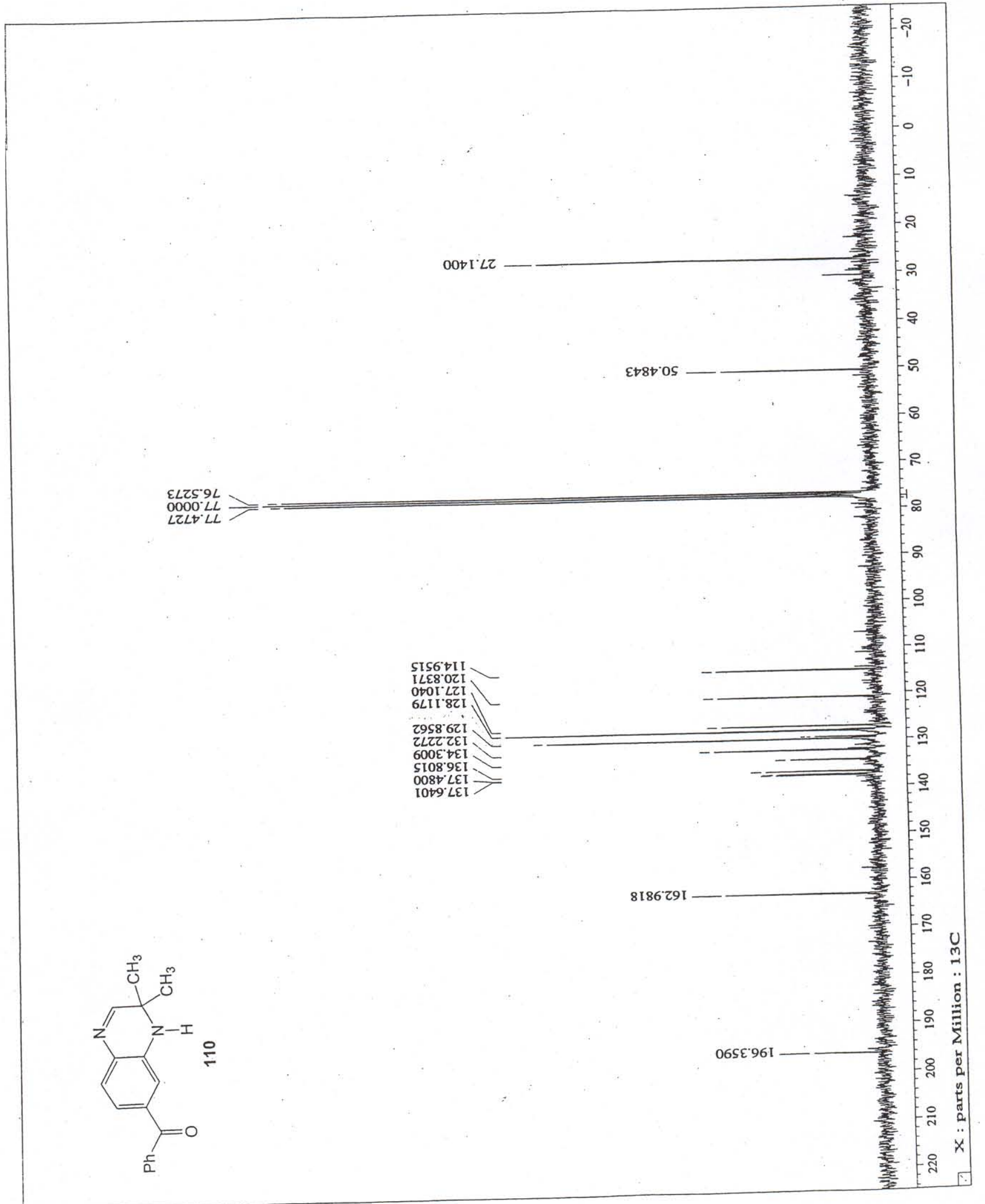

Figure 57: ${ }^{13} \mathrm{C}$ NMR of Compound $\mathbf{1 1 0}$ 


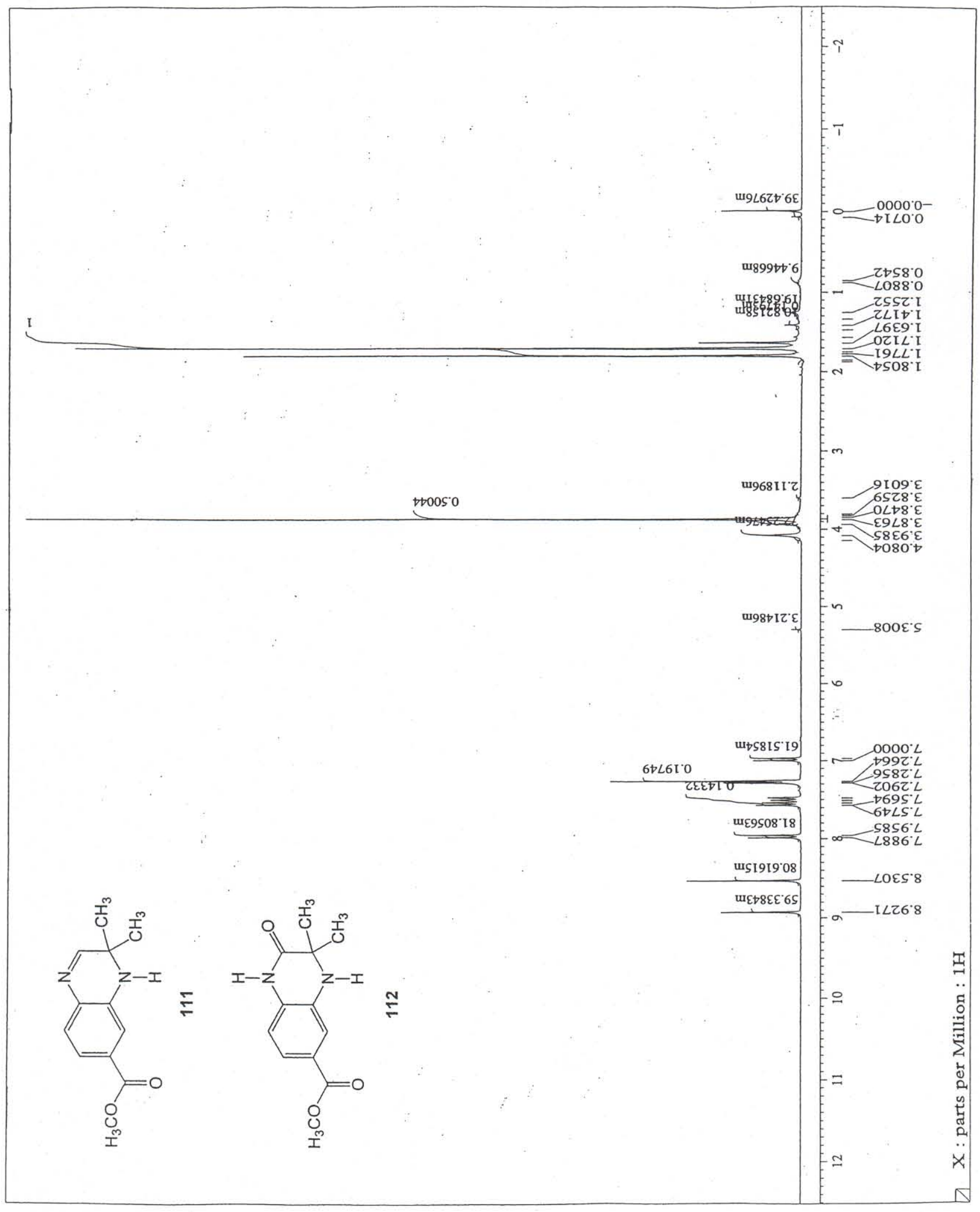

Figure 58: ${ }^{1} \mathrm{H}$ NMR of Compounds 111 and 112 


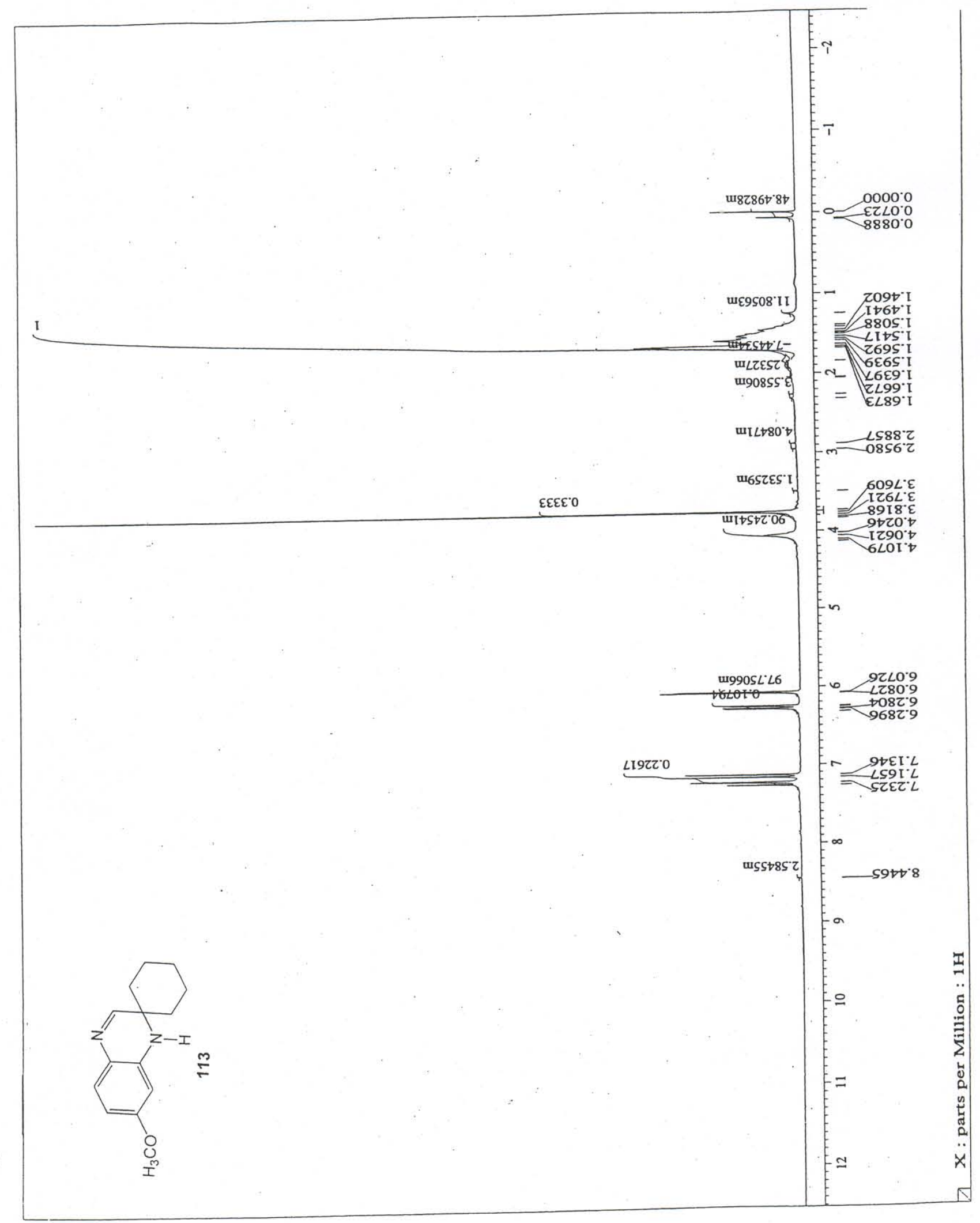

Figure 59: ${ }^{1} \mathrm{H}$ NMR of Compound 113 


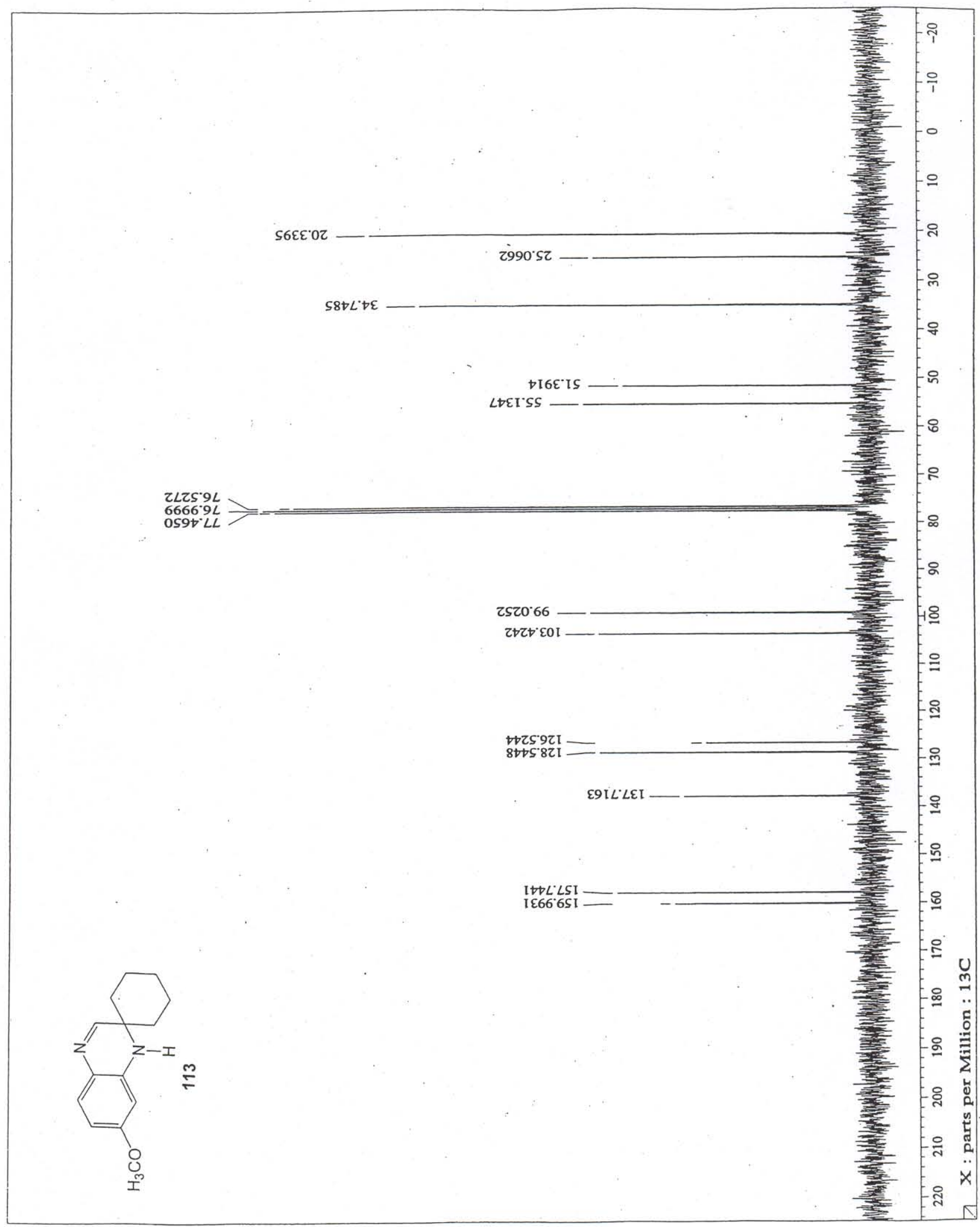

Figure 60: ${ }^{13} \mathrm{C}$ NMR of Compound 113 


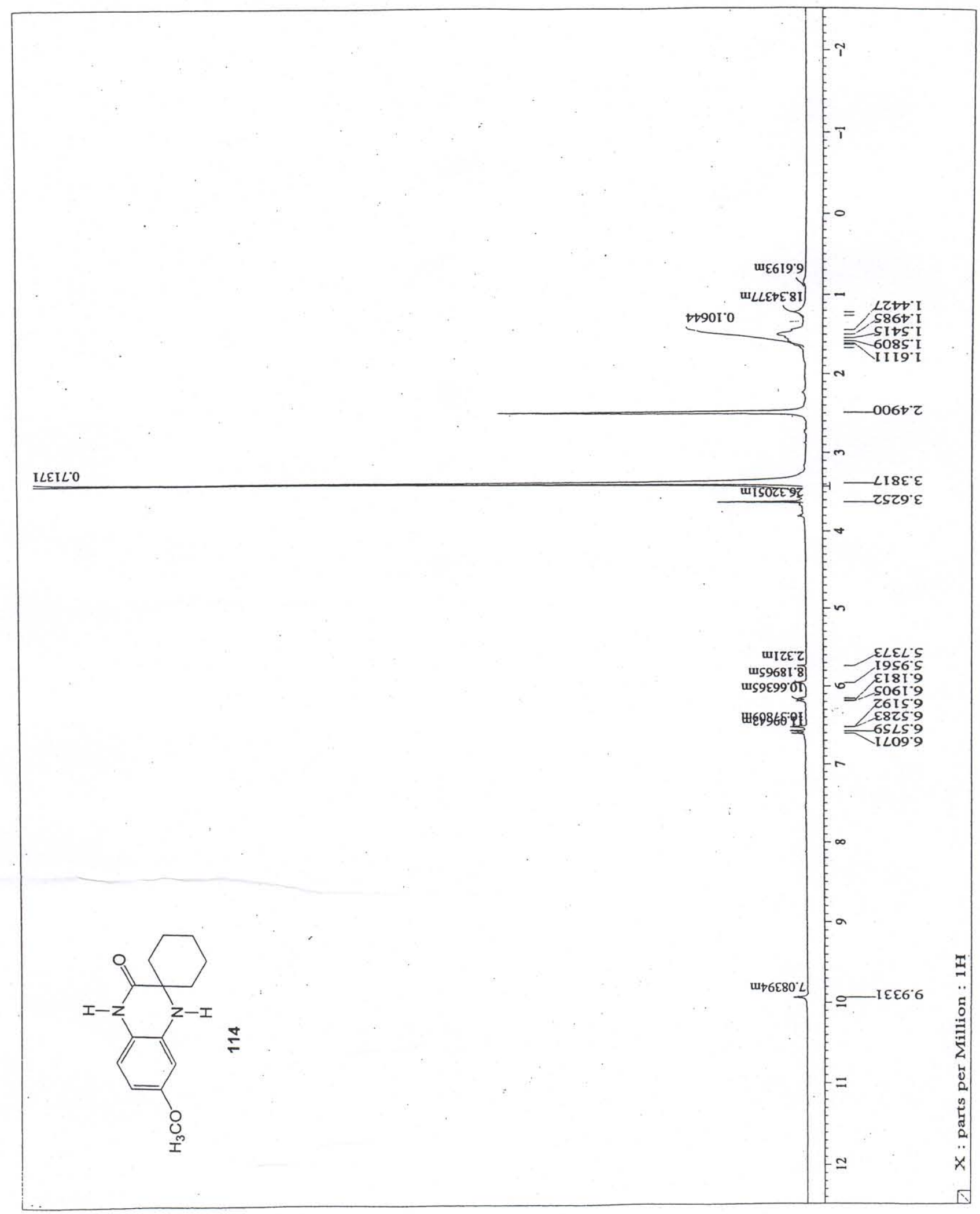

Figure 61: ${ }^{1} \mathrm{H}$ NMR of Compound 114 


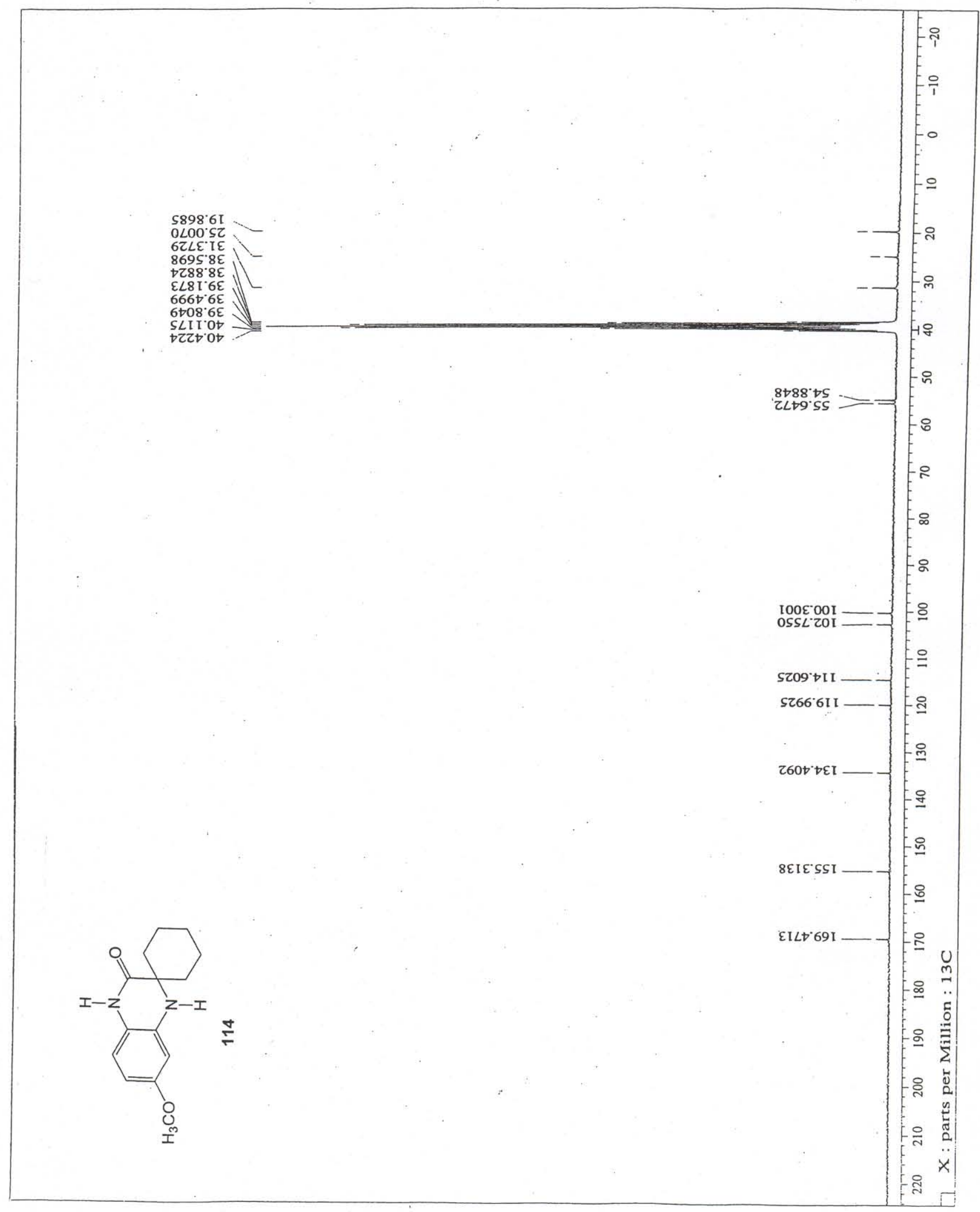

Figure 62: ${ }^{13} \mathrm{C}$ NMR of Compound 114 


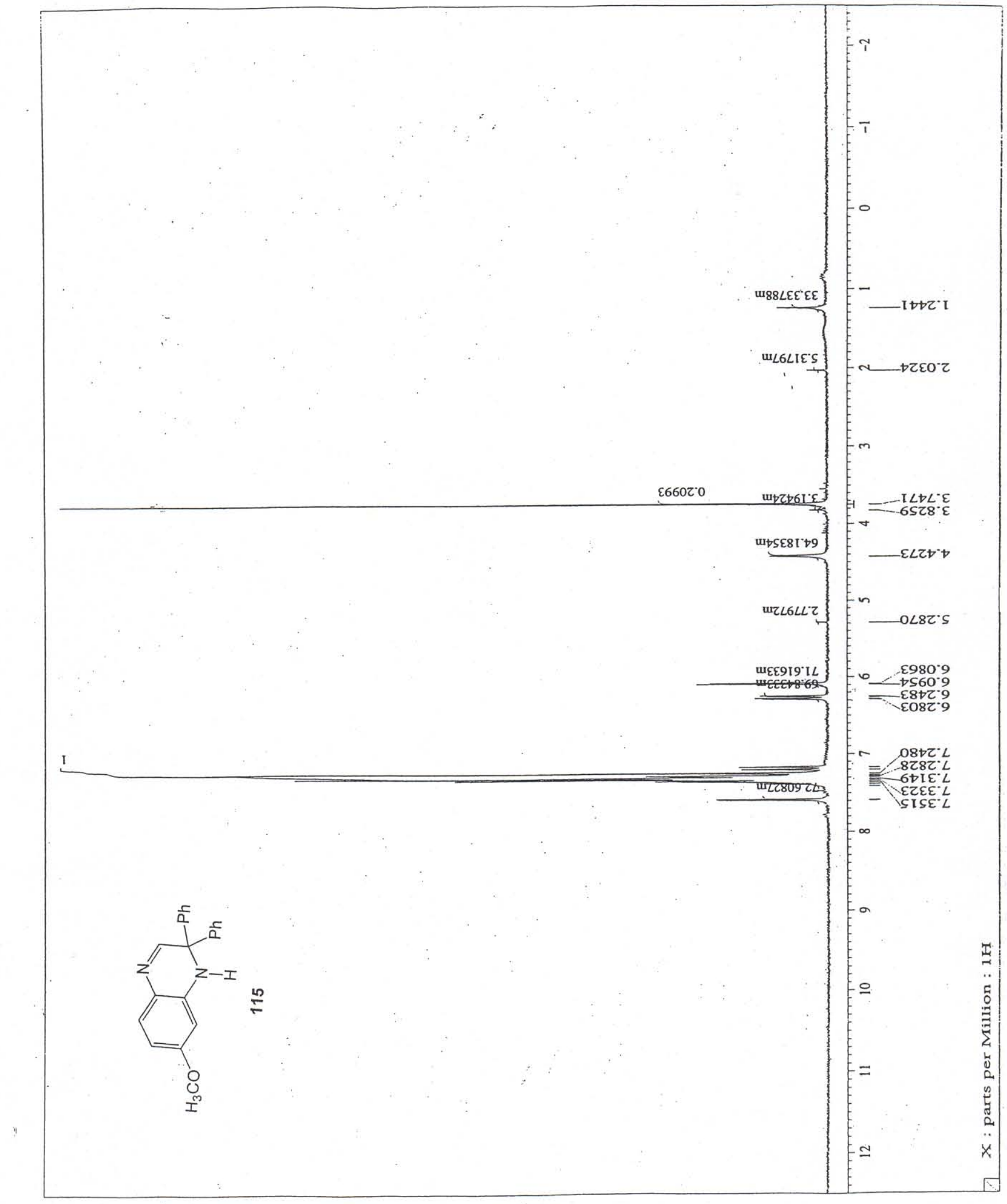

Figure 63: ${ }^{1} \mathrm{H}$ NMR of Compound $\mathbf{1 1 5}$ 


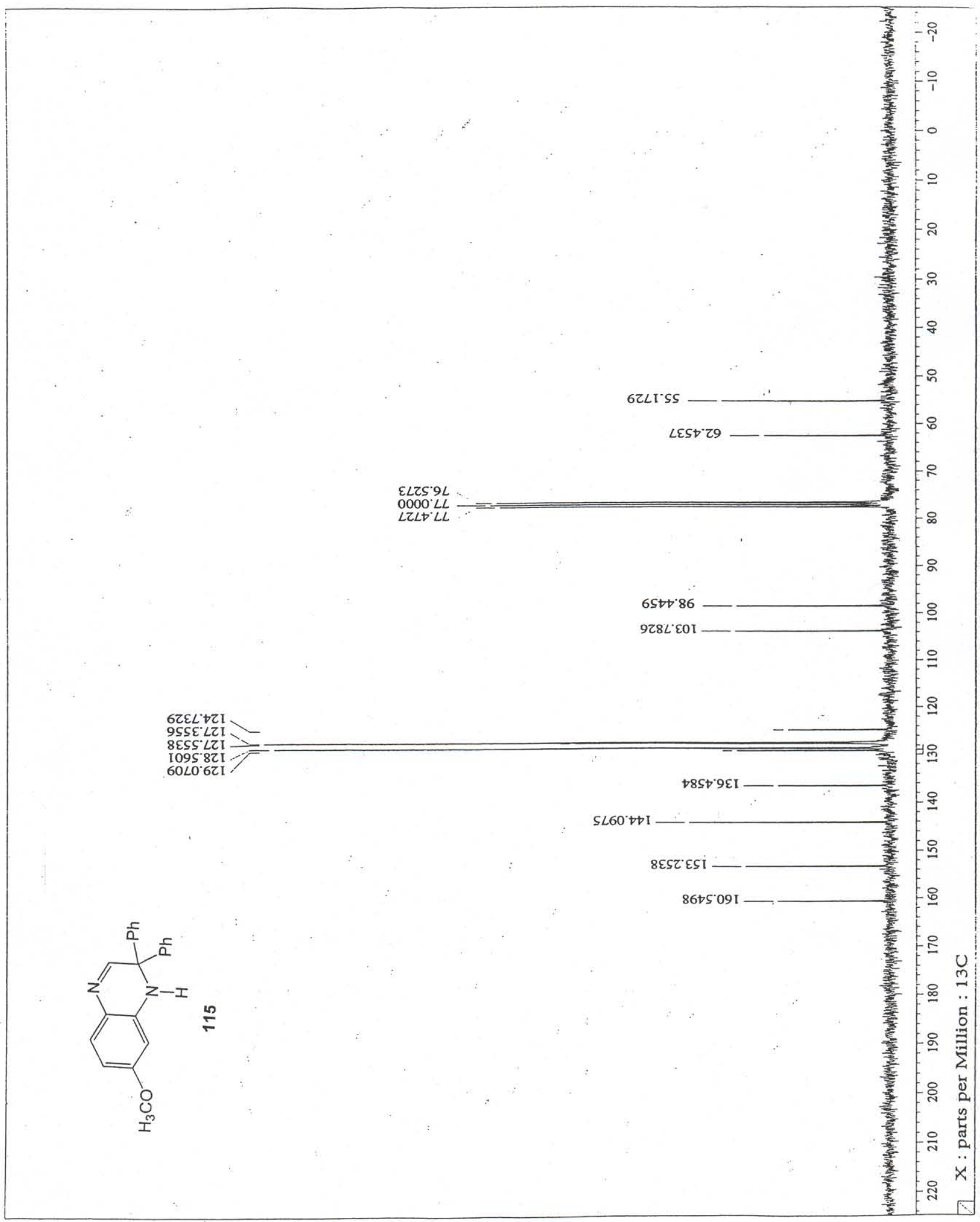

Figure 64: ${ }^{13} \mathrm{C}$ NMR of Compound 115 


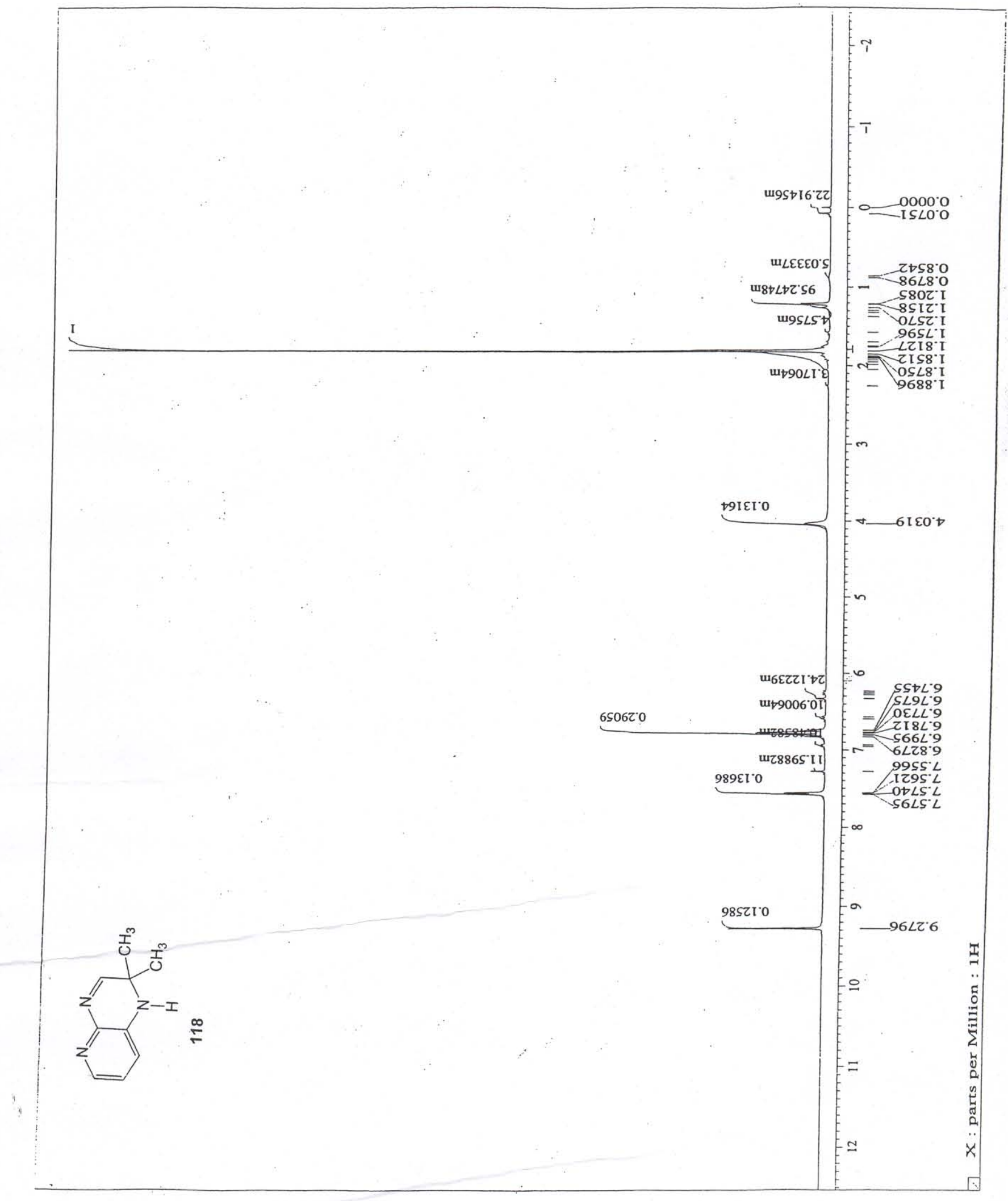

Figure 65: ${ }^{1} \mathrm{H}$ NMR of Compound $\mathbf{1 1 8}$ 


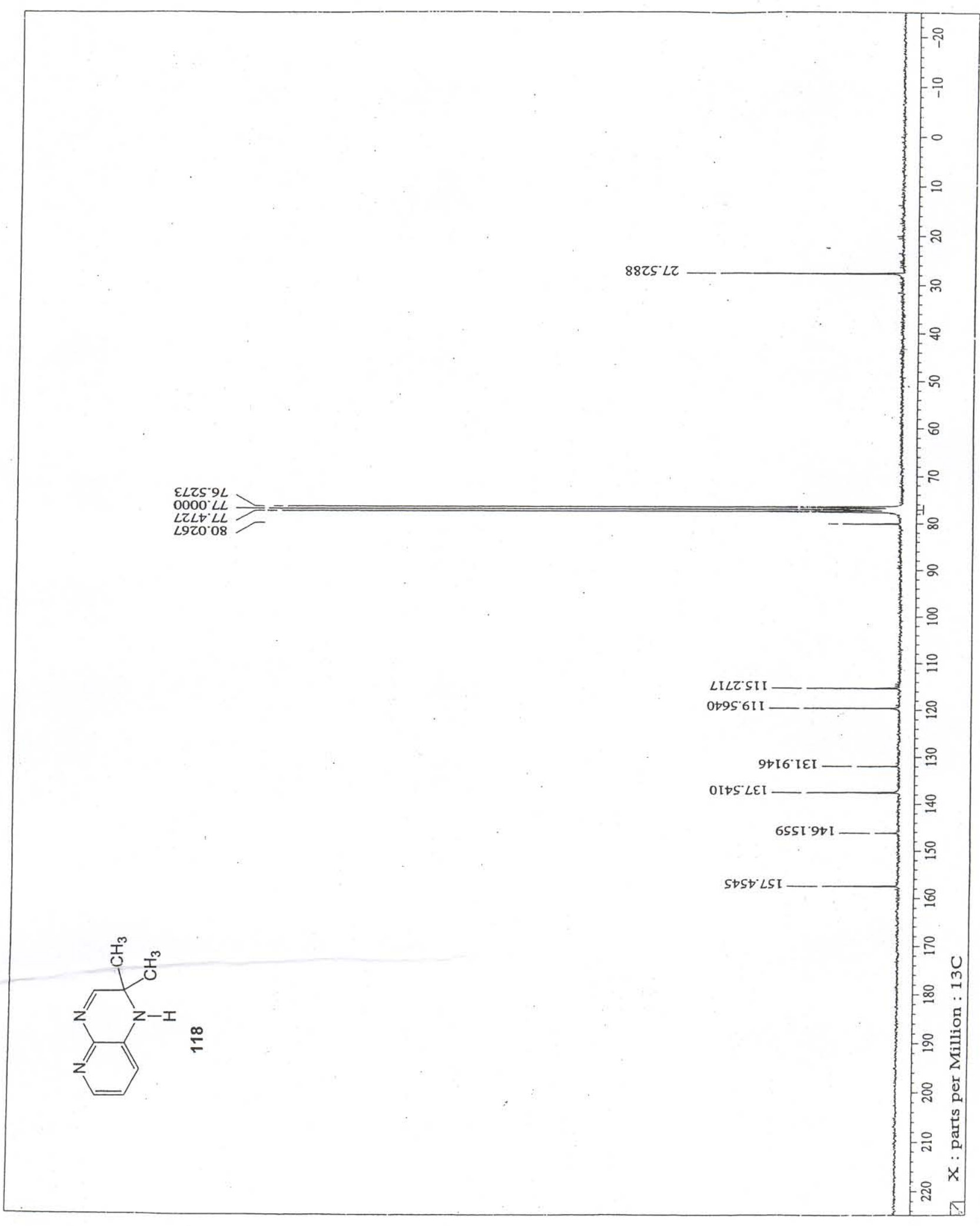

Figure 66: ${ }^{13} \mathrm{C}$ NMR of Compound 118 


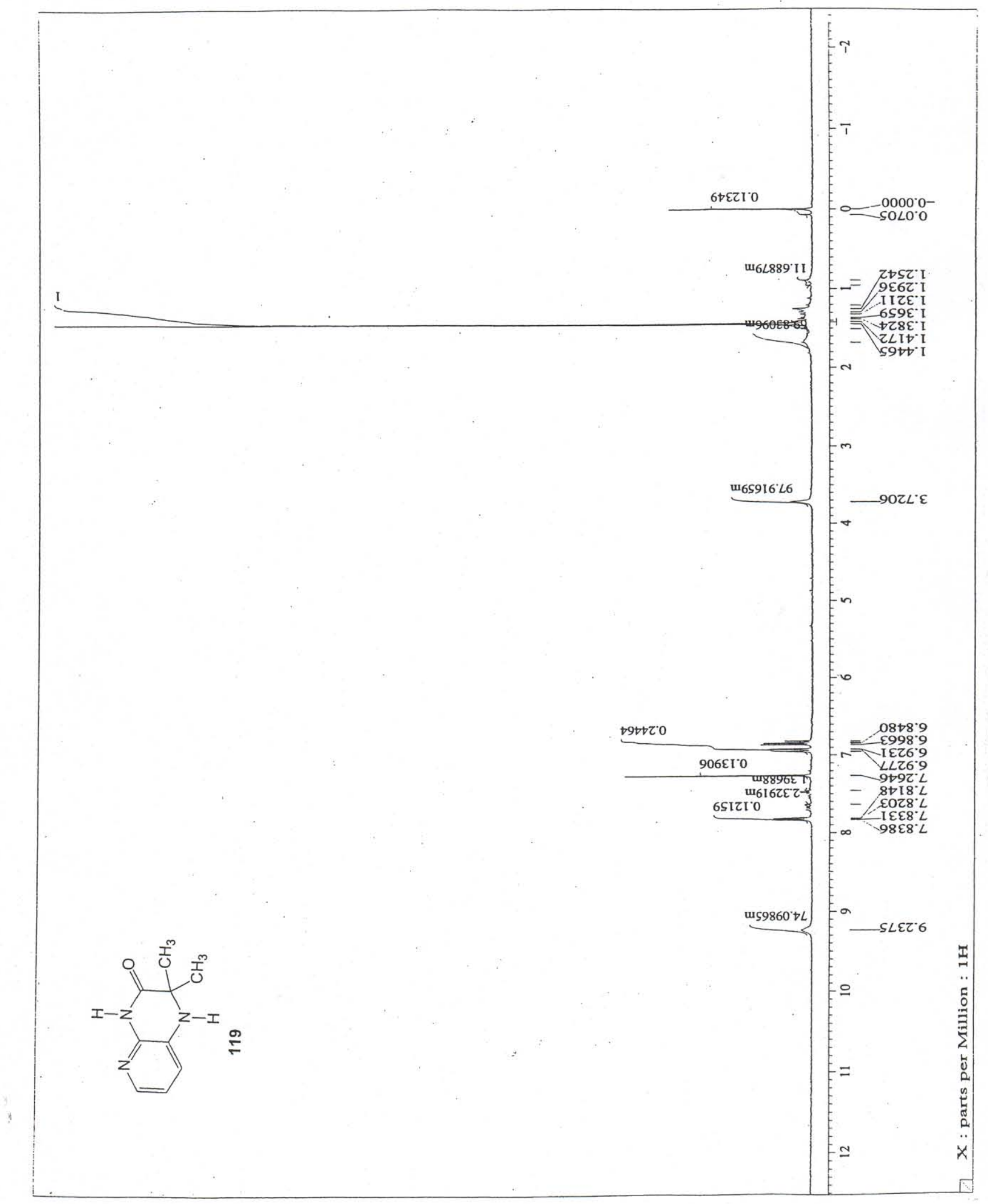

Figure 67: ${ }^{1} \mathrm{H}$ NMR of Compound 119 


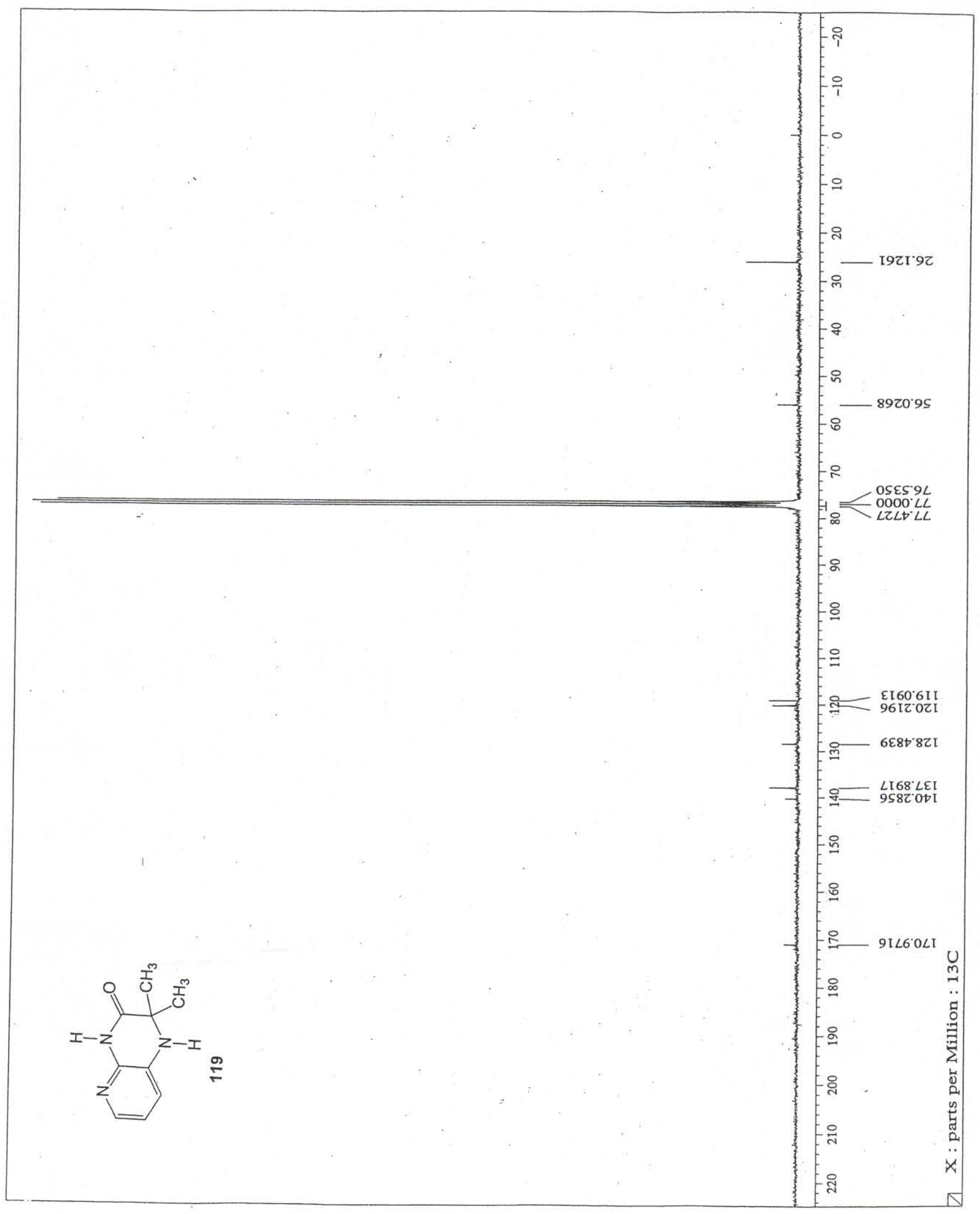

Figure 68: ${ }^{13} \mathrm{C}$ NMR of Compound 119 


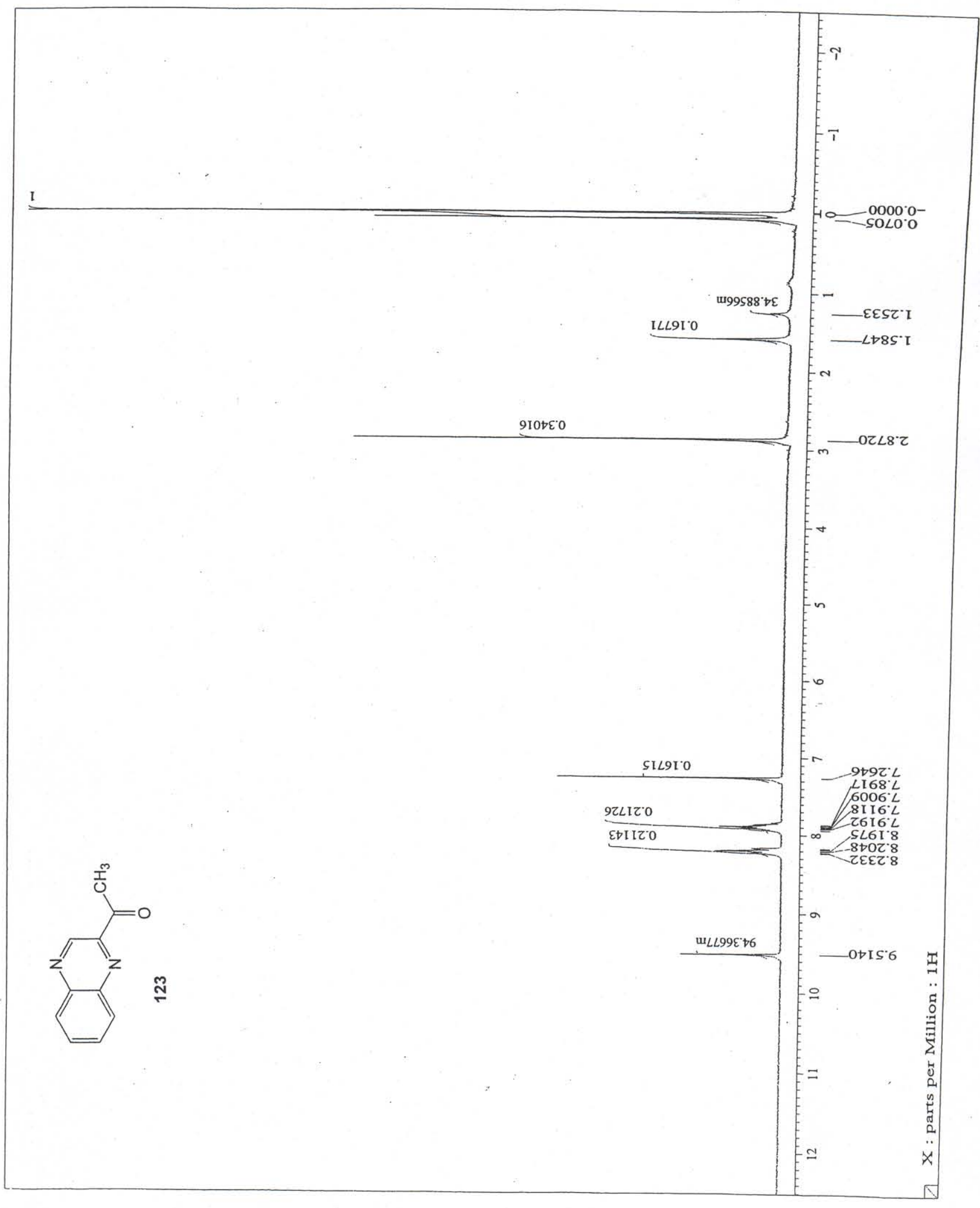

Figure 69: ${ }^{1} \mathrm{H}$ NMR of Compound 123 


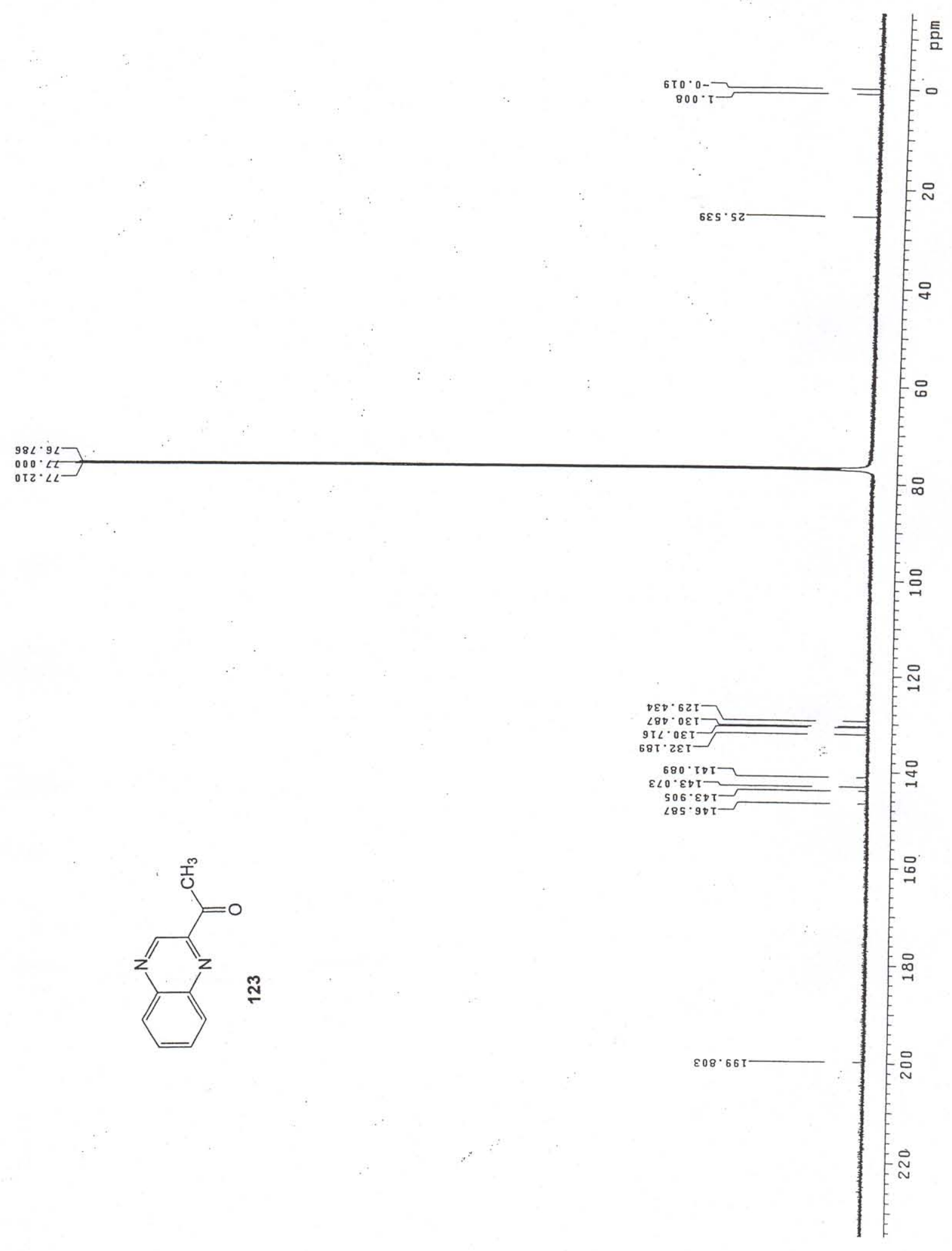

Figure 70: ${ }^{13} \mathrm{C}$ NMR of Compound 123 


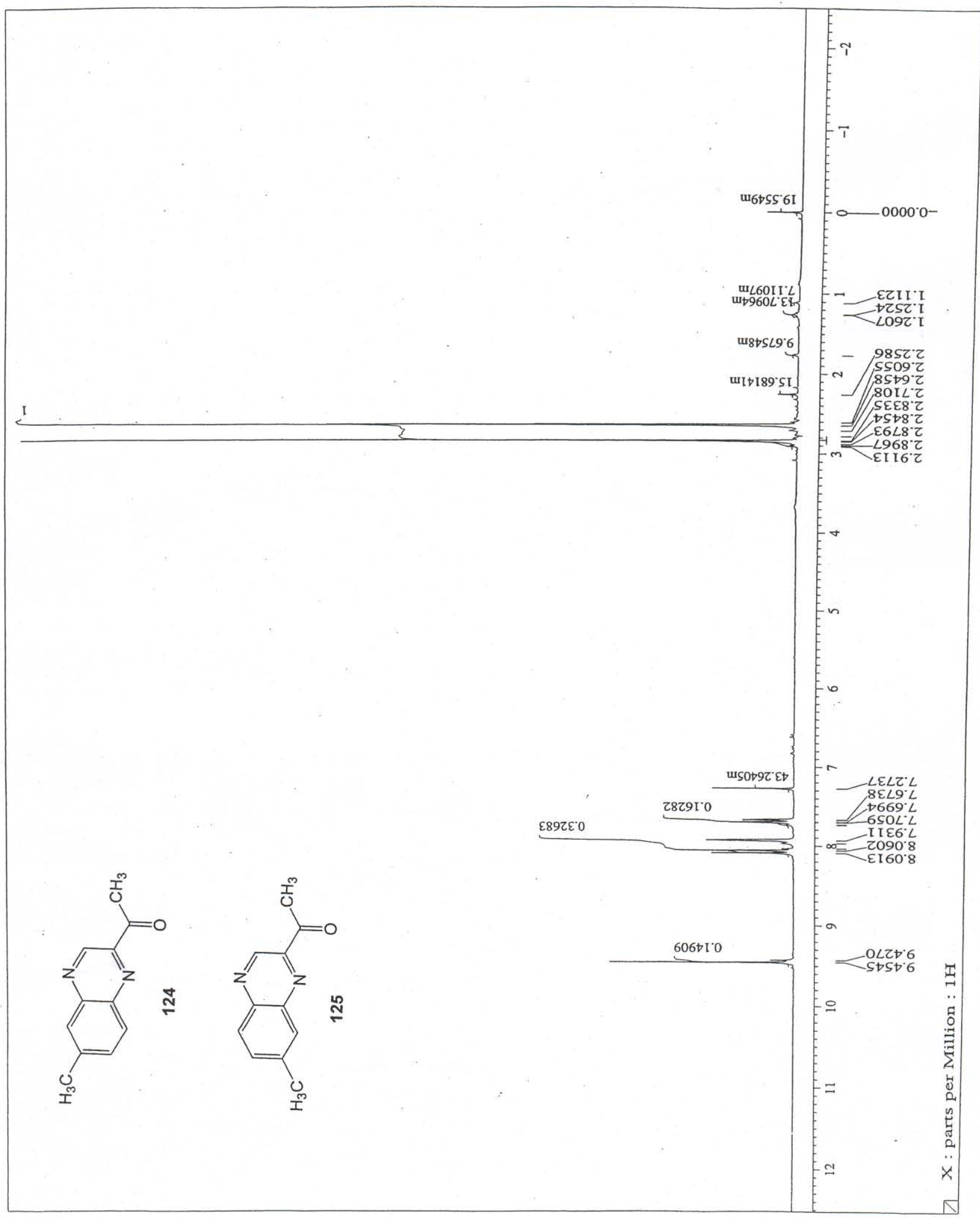

Figure 71: ${ }^{1} \mathrm{H}$ NMR of Compounds 124 and 125 


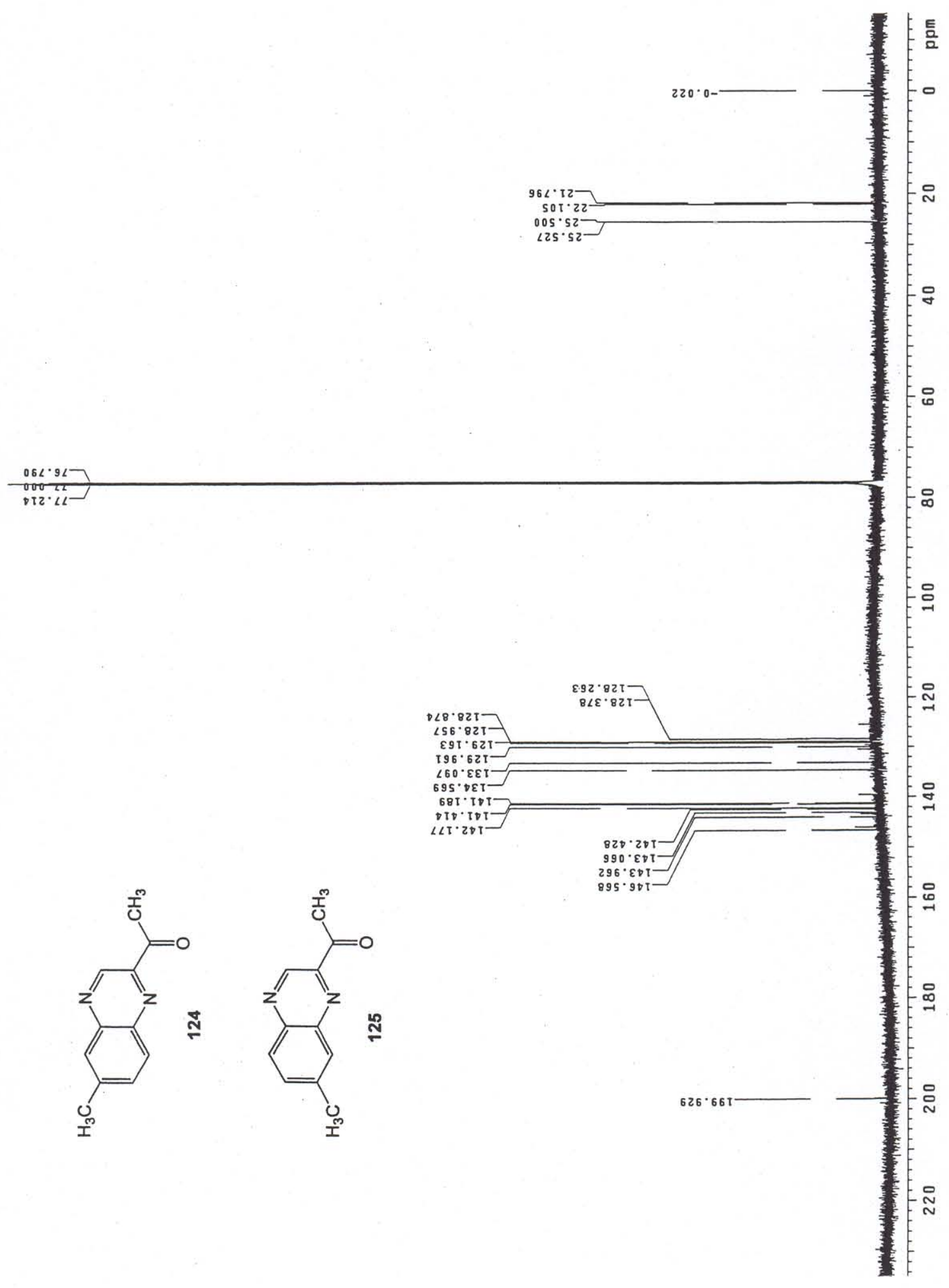

Figure 72: ${ }^{13} \mathrm{C}$ NMR of Compounds 124 and 125 


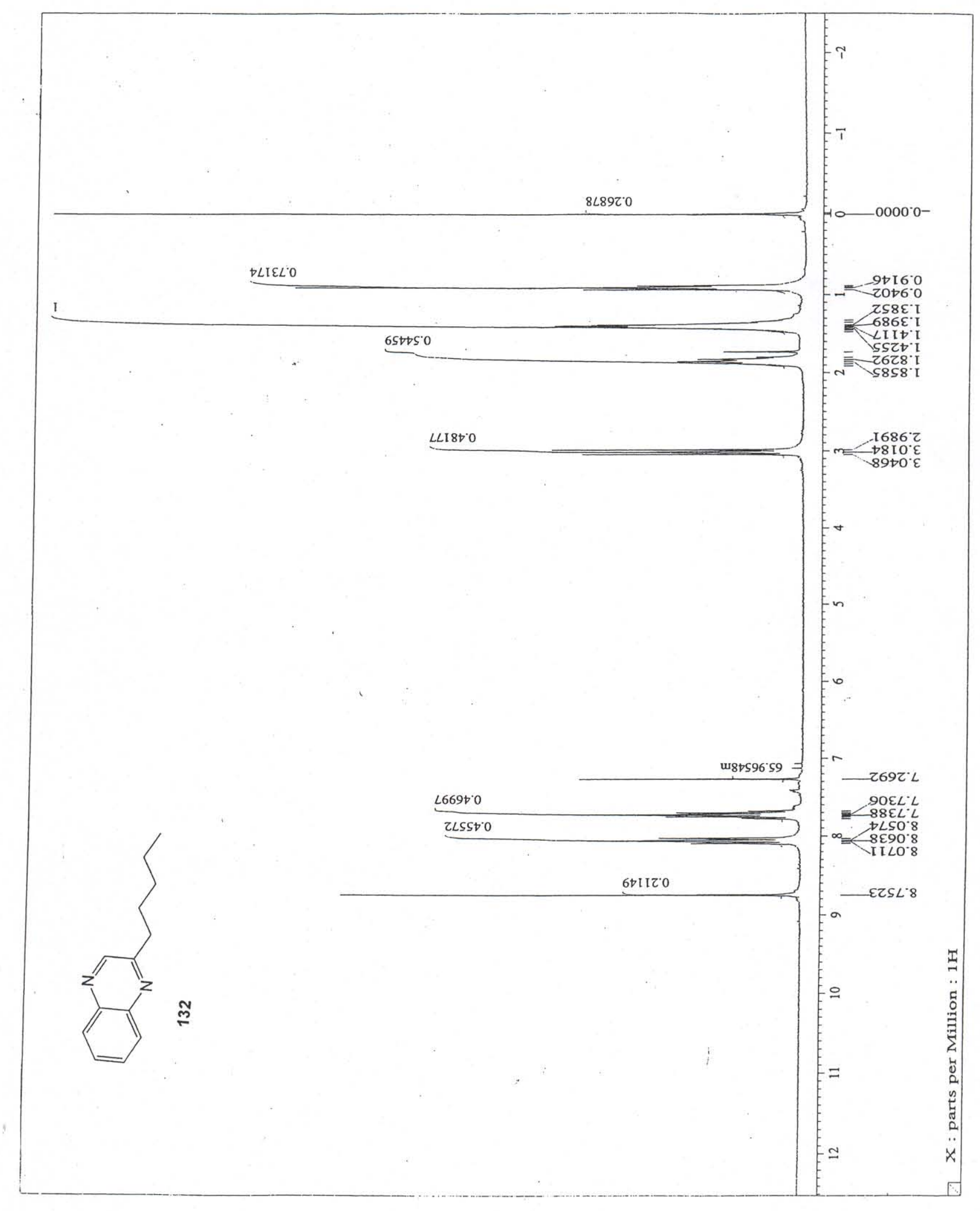

Figure 73: ${ }^{1} \mathrm{H}$ NMR of Compound 132 


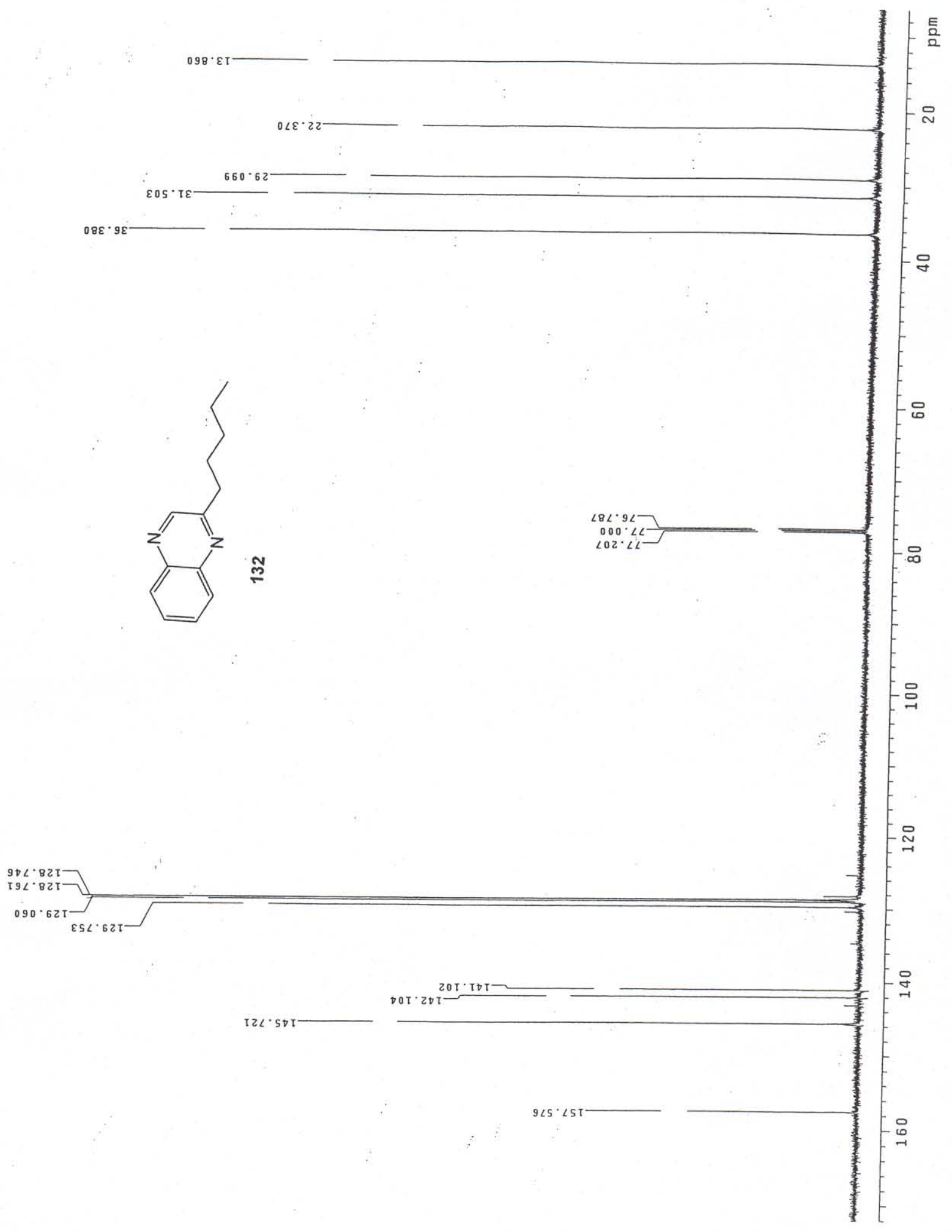

Figure 74: ${ }^{13} \mathrm{C}$ NMR of Compound 132 


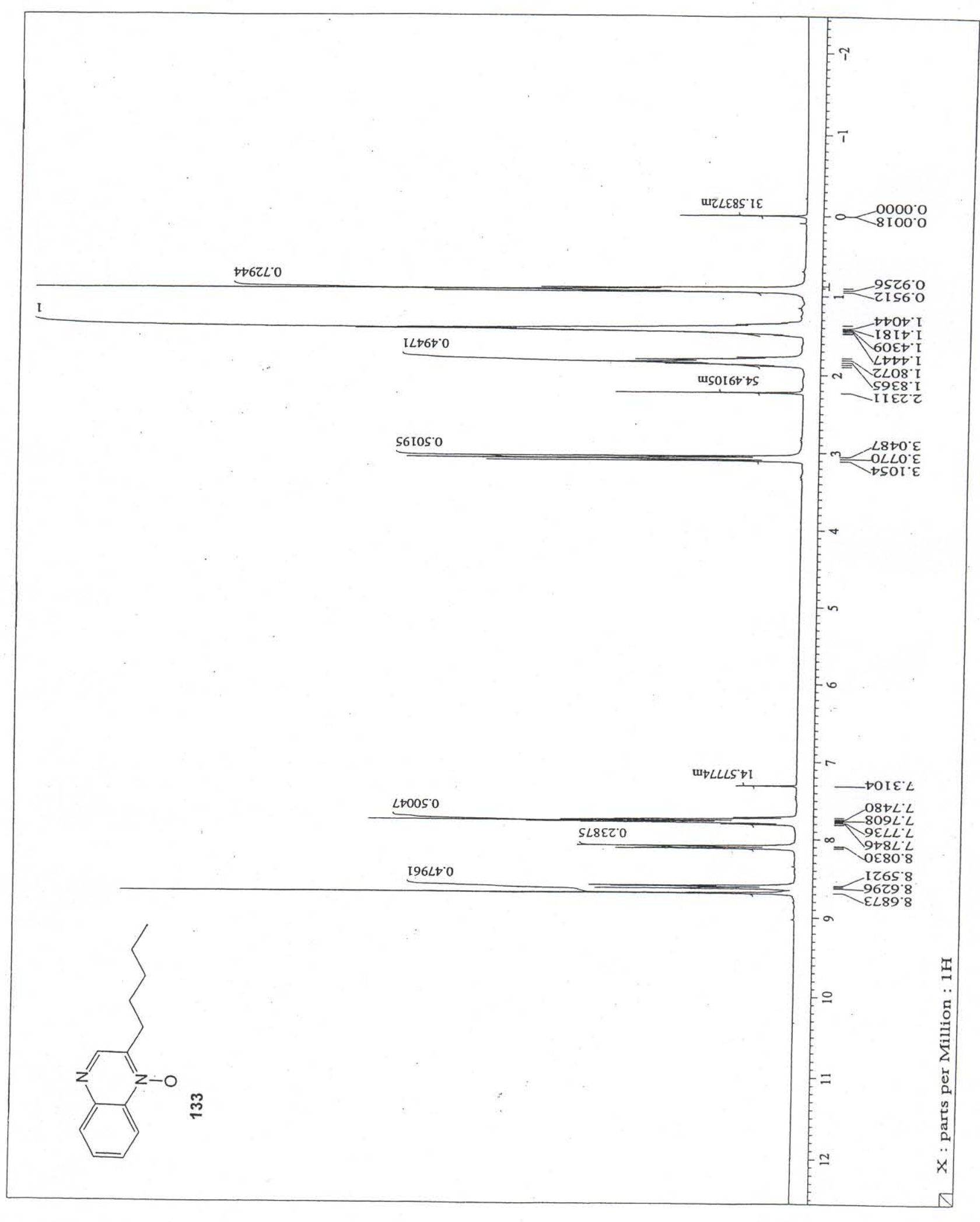

Figure 75: ${ }^{1} \mathrm{H}$ NMR of Compound 133 


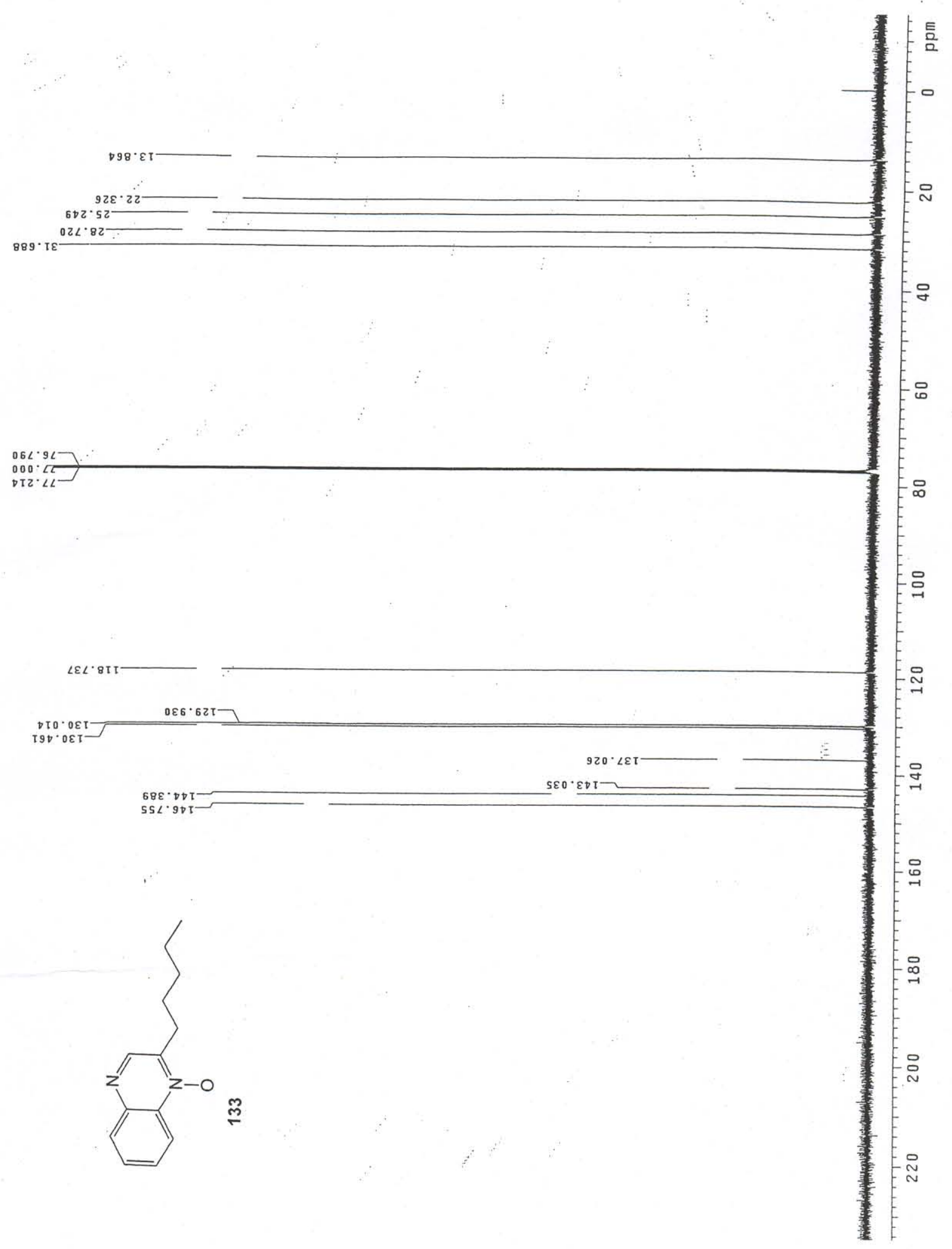

Figure 76: ${ }^{13} \mathrm{C}$ NMR of Compound 133 


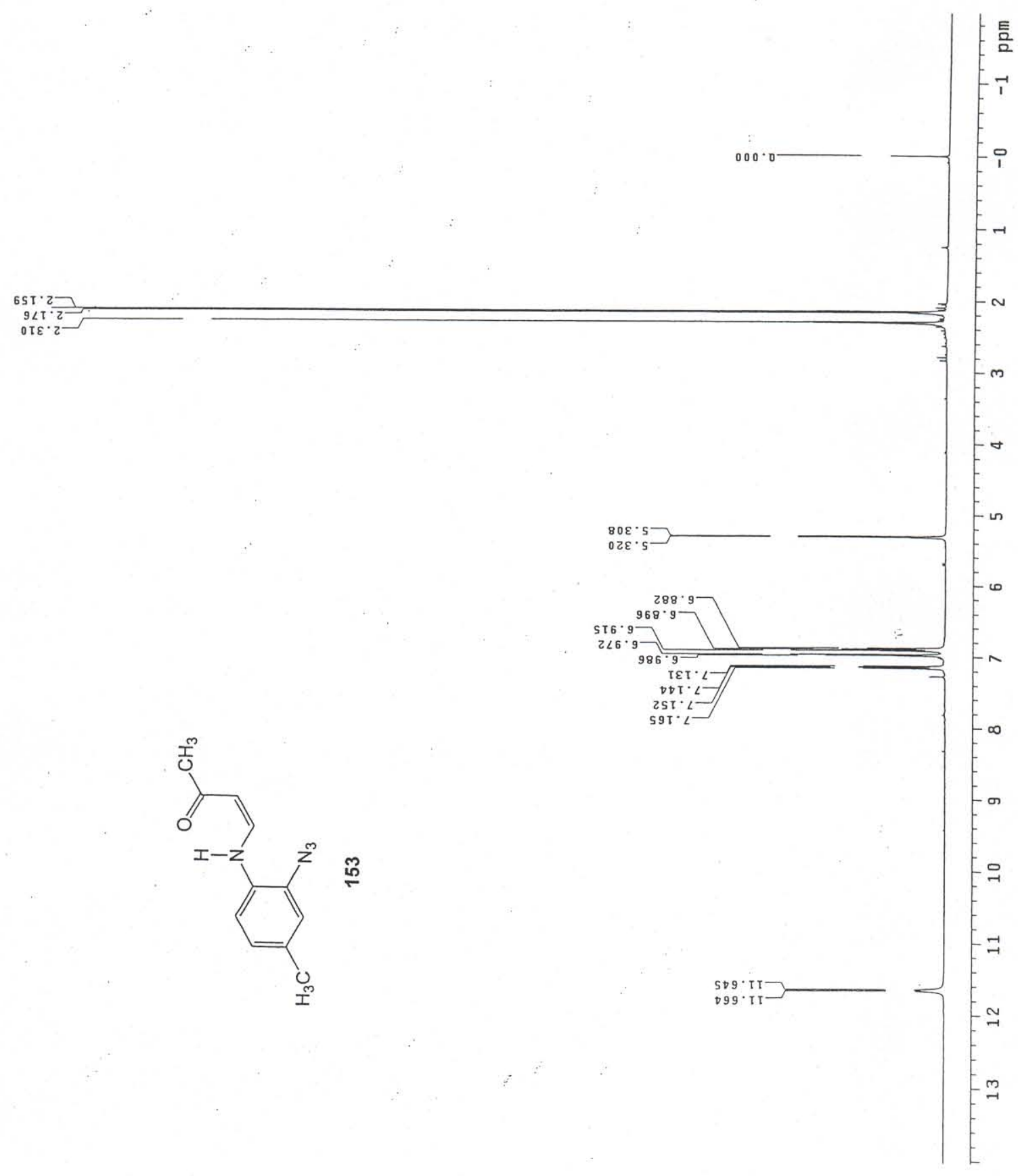

Figure 77: ${ }^{1} \mathrm{H}$ NMR of Compound 153 


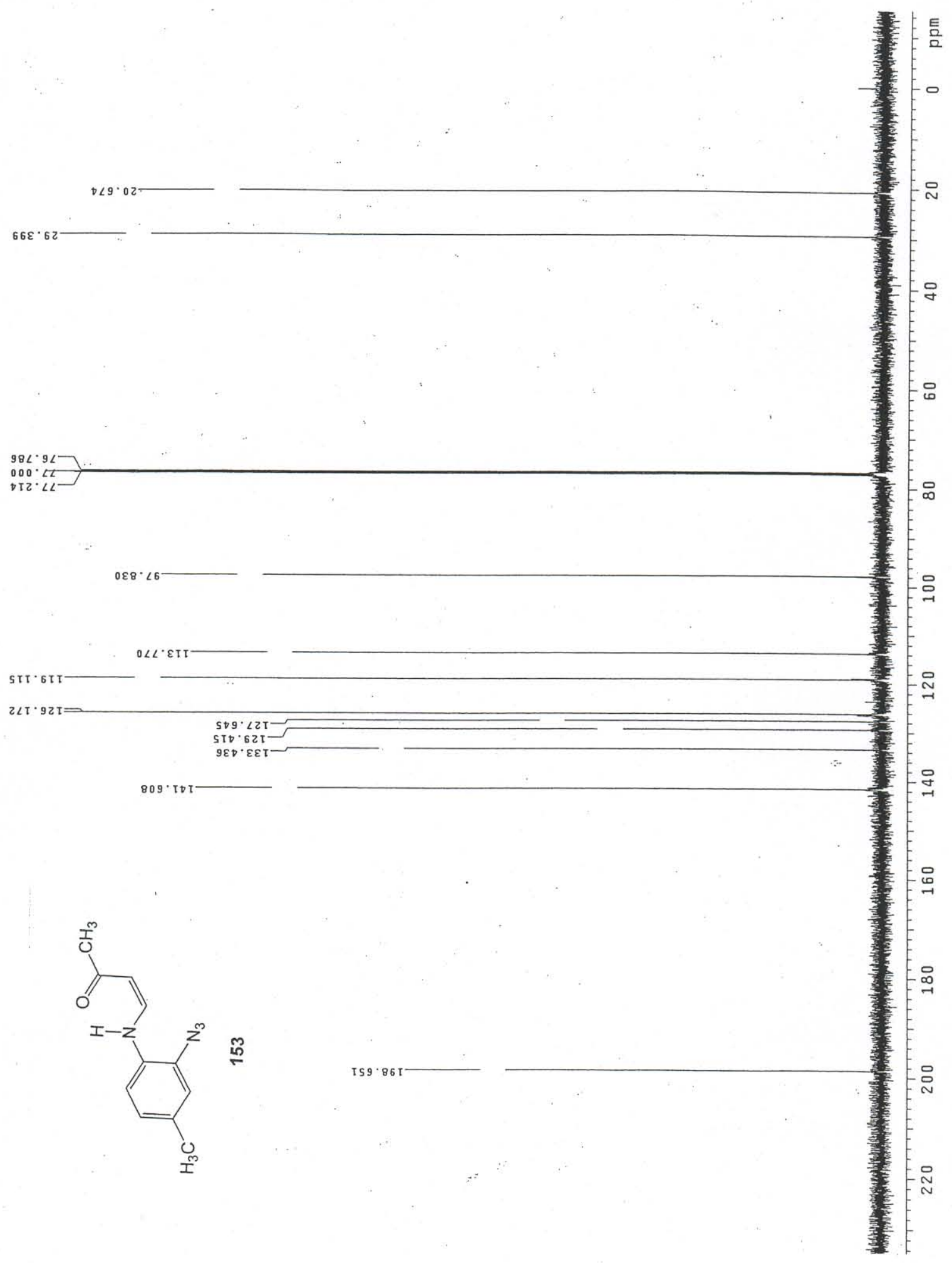

Figure 78: ${ }^{13} \mathrm{C}$ NMR of Compound 153 


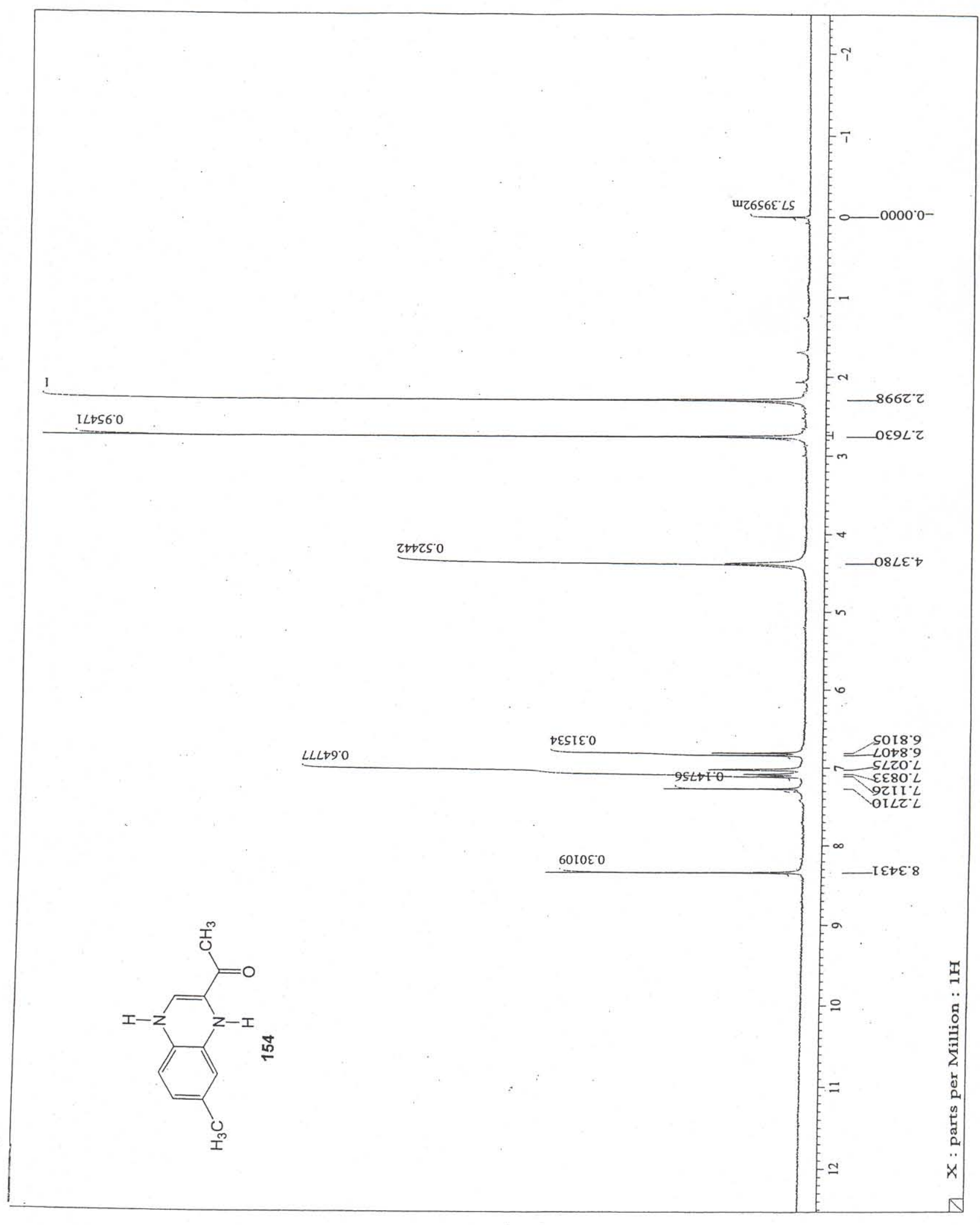

Figure 79: ${ }^{1} \mathrm{H}$ NMR of Compound 154 


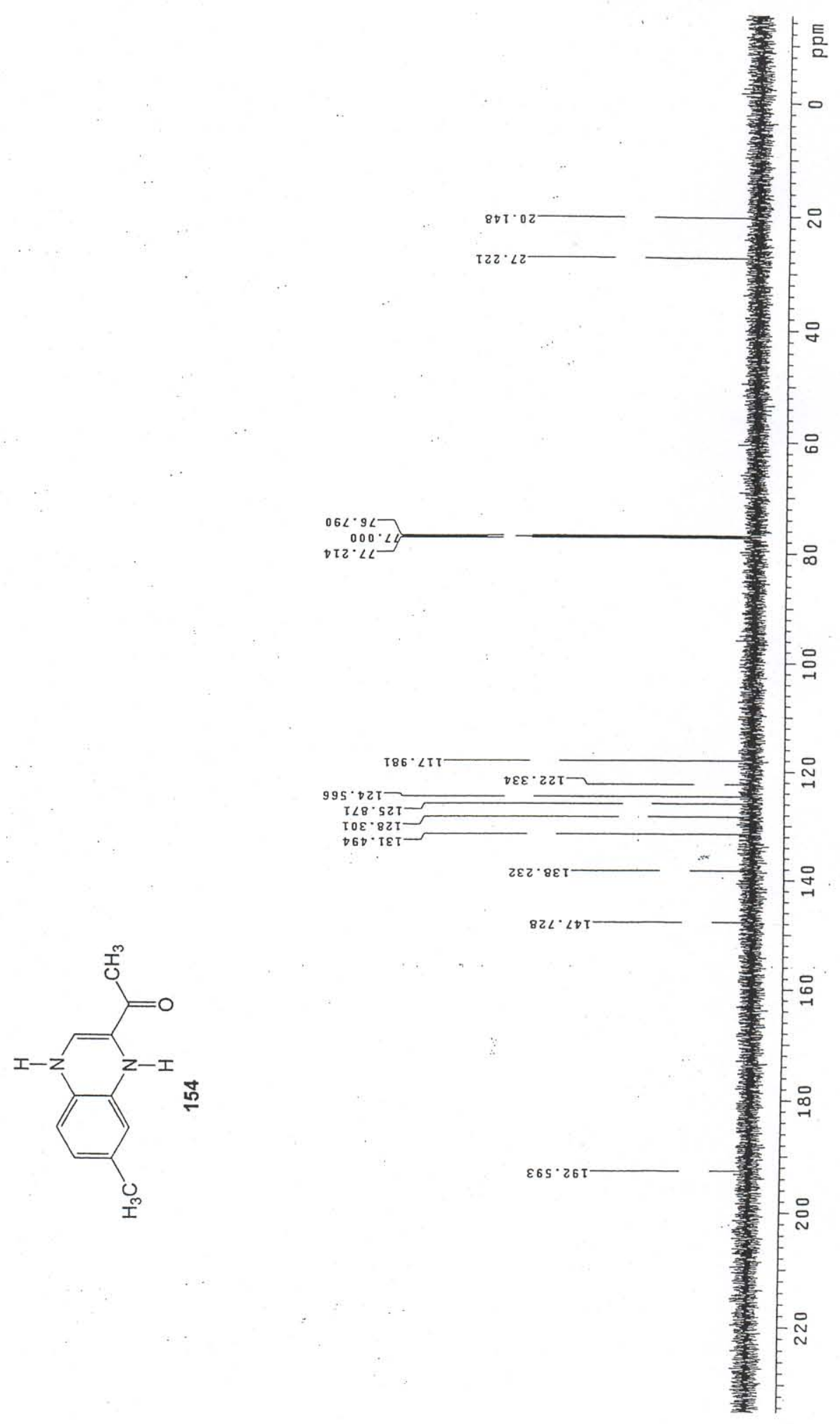

Figure 80: ${ }^{13} \mathrm{C}$ NMR of Compound 154 


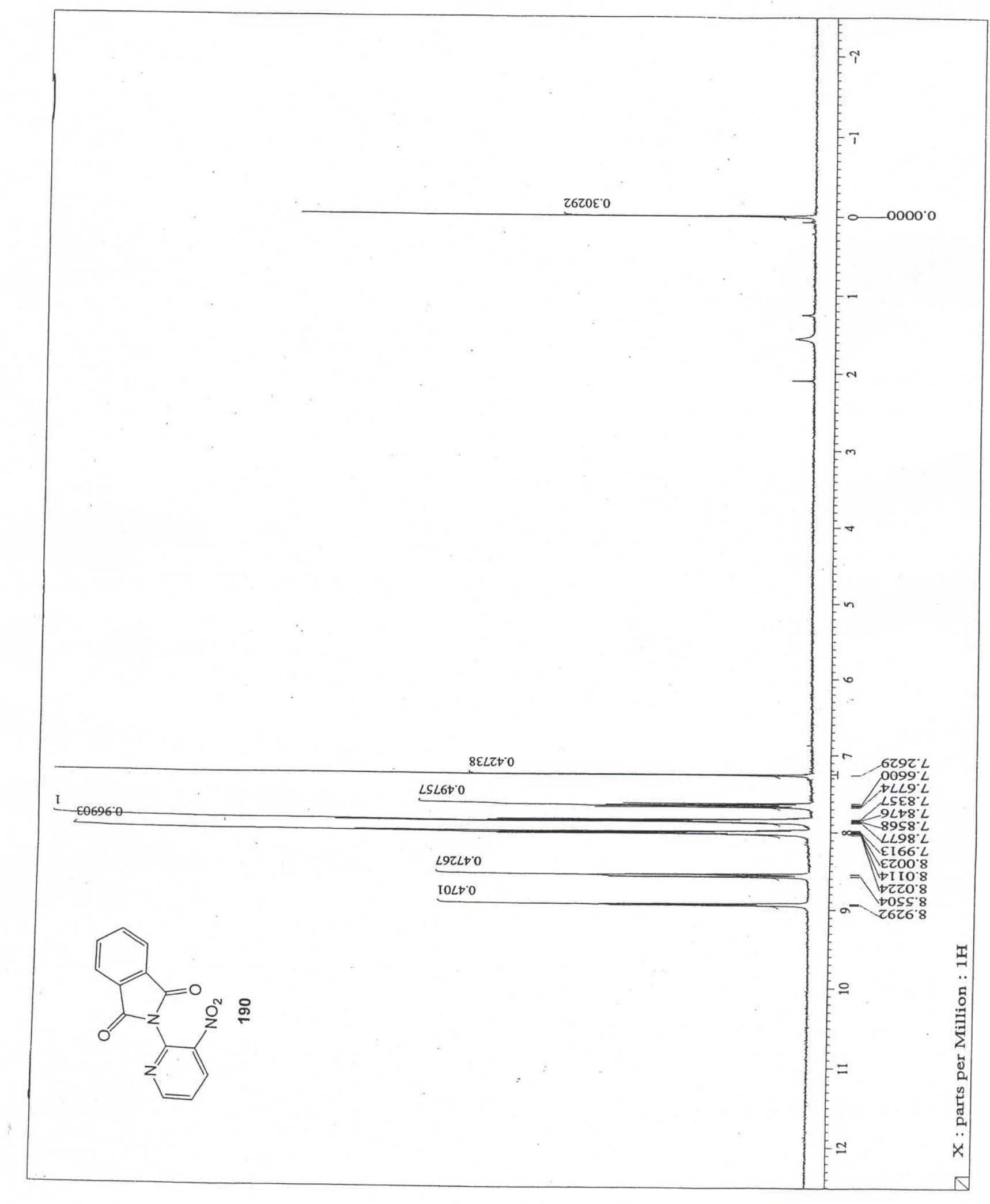

Figure 81: ${ }^{1} \mathrm{H}$ NMR of Compound 190 


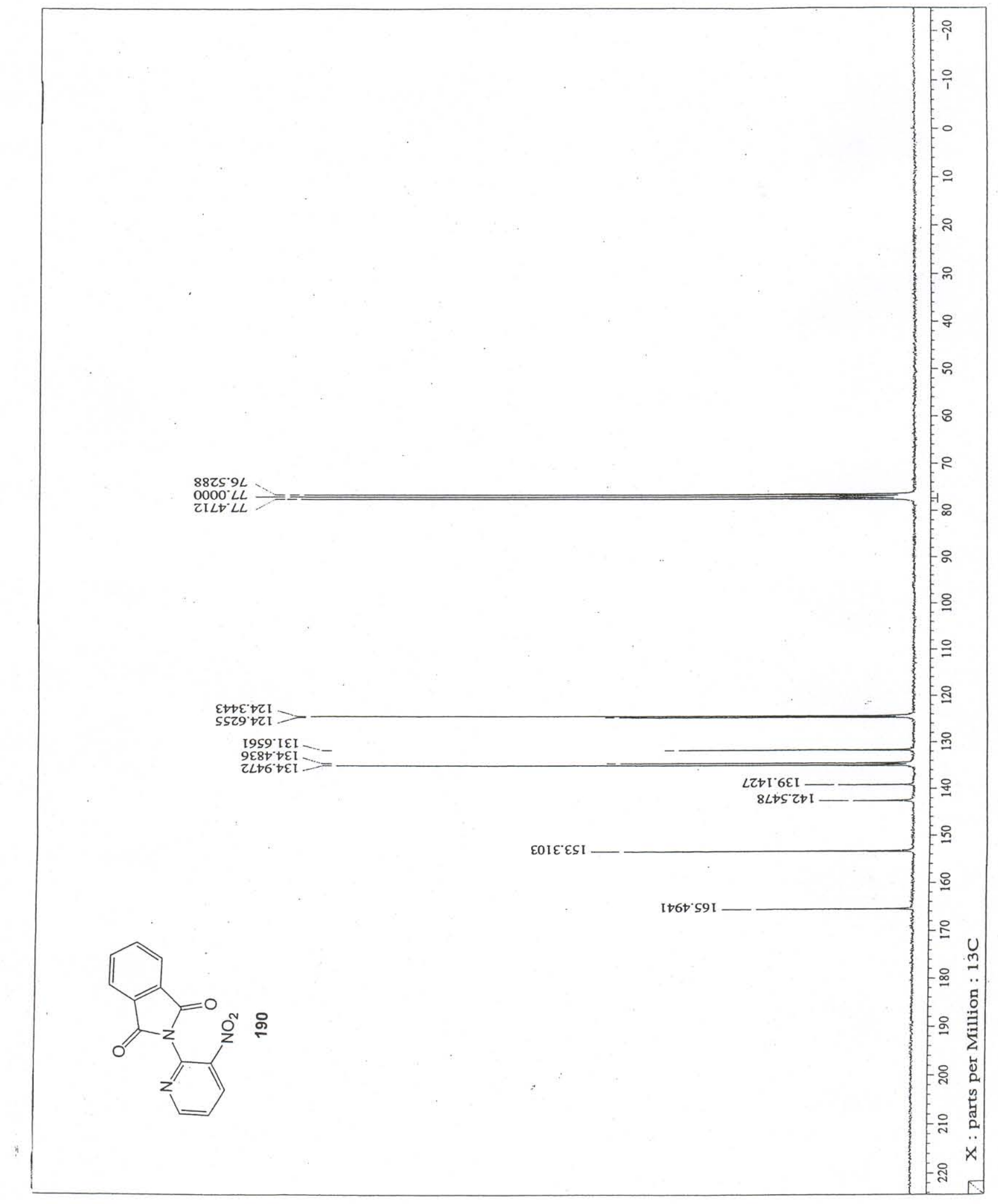

Figure 82: ${ }^{13} \mathrm{C}$ NMR of Compound 190 


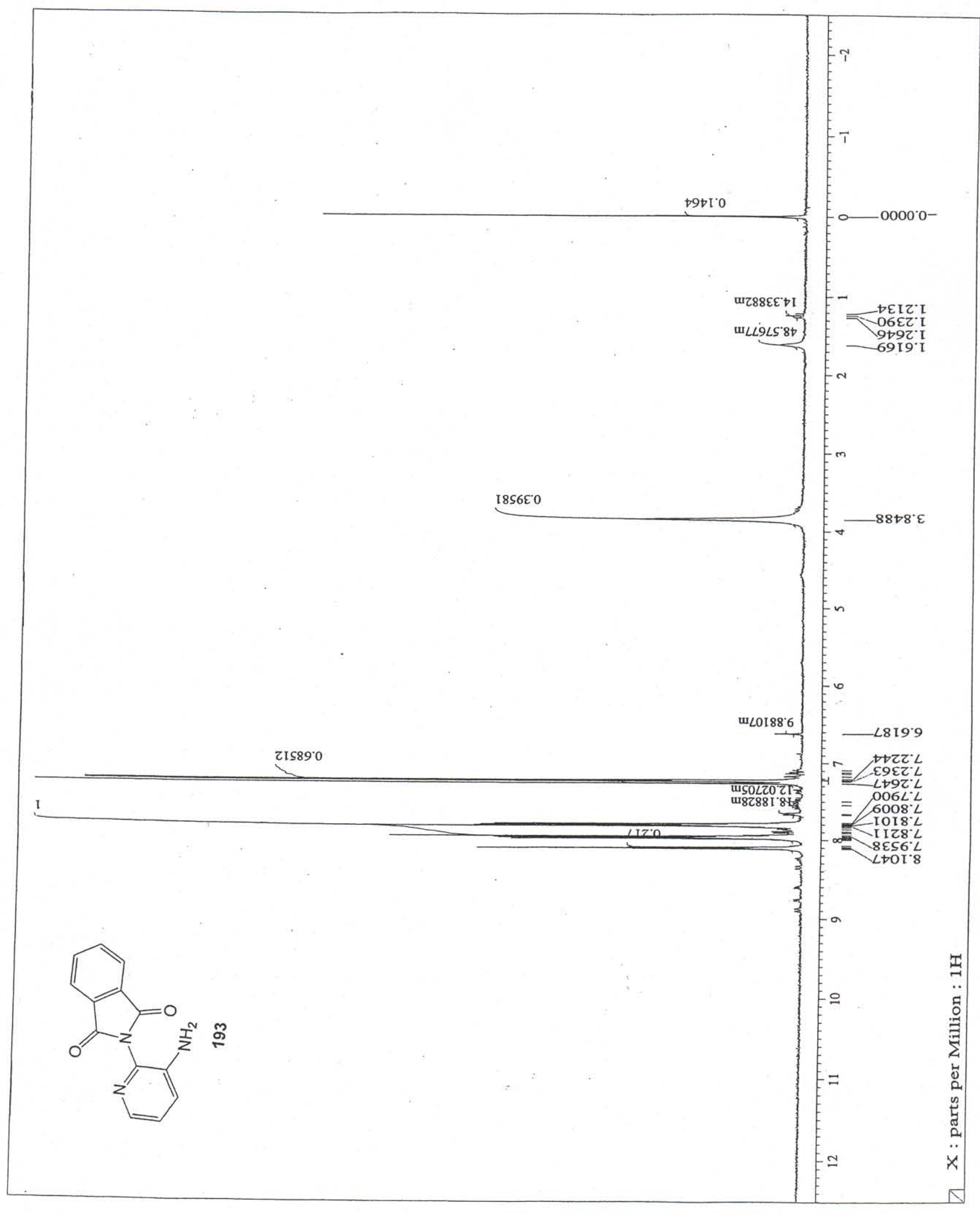

Figure 83: ${ }^{1} \mathrm{H}$ NMR of Compound 193 


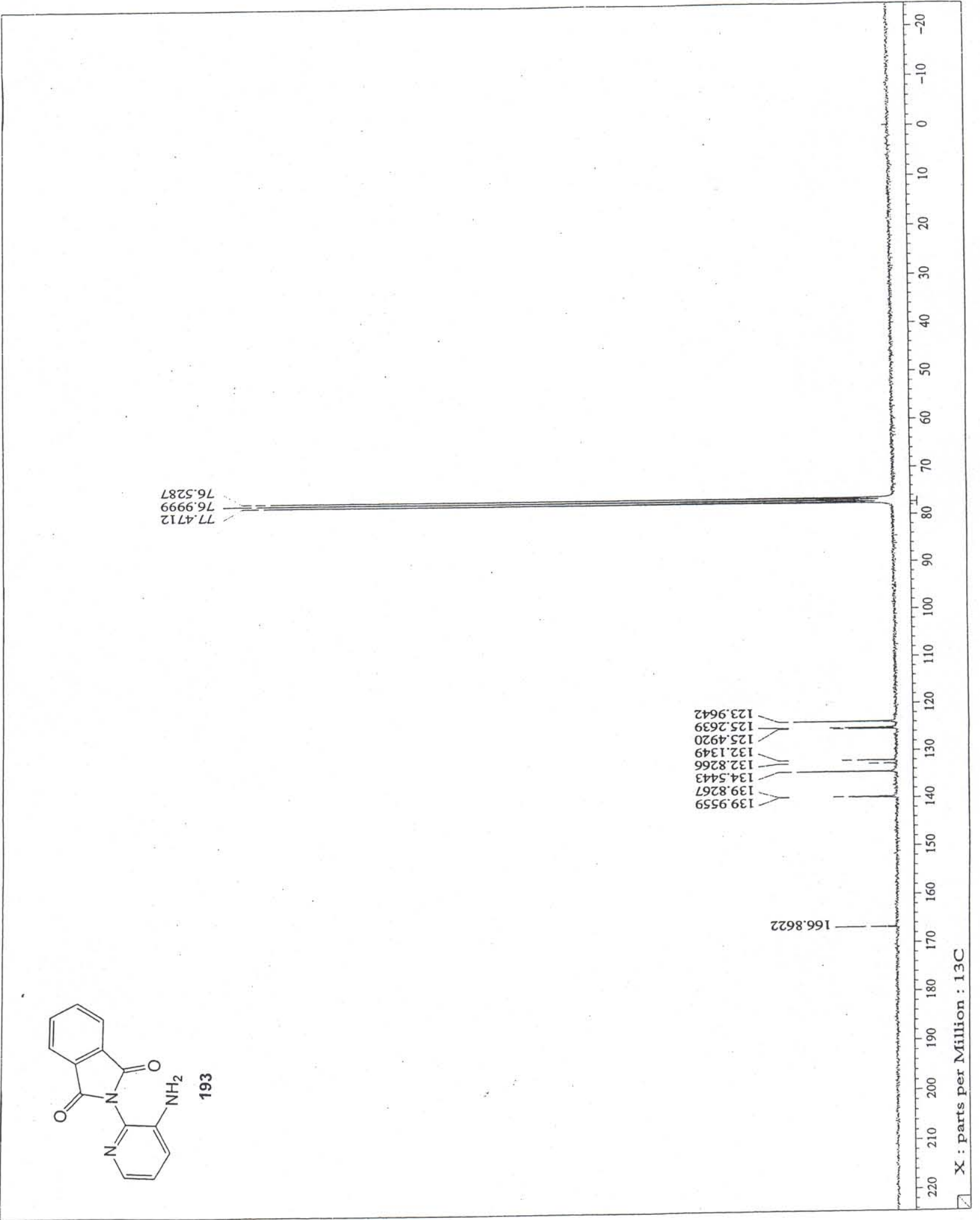

Figure 84: ${ }^{13} \mathrm{C}$ NMR of Compound 193 


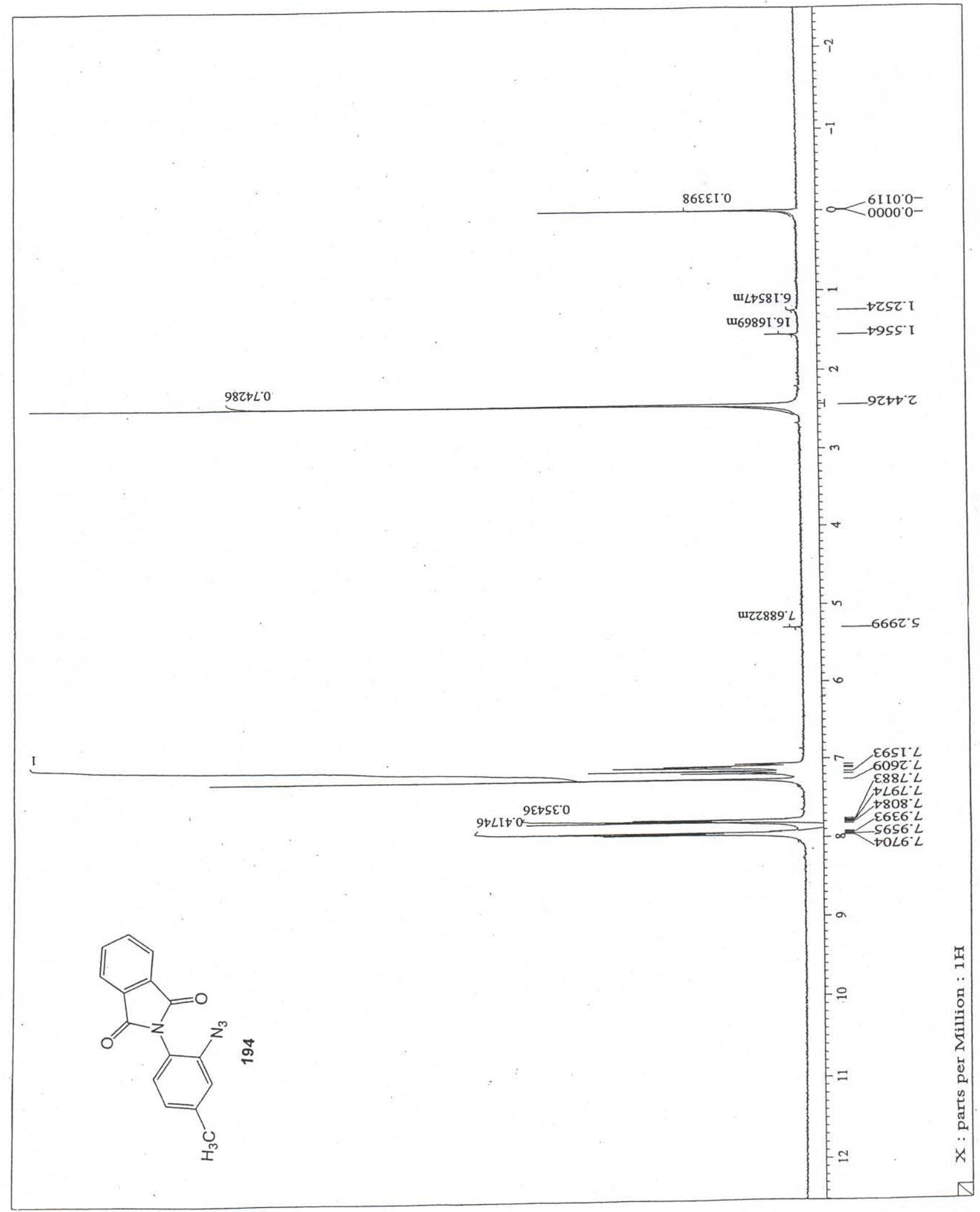

Figure 85: ${ }^{1} \mathrm{H}$ NMR of Compound 194 


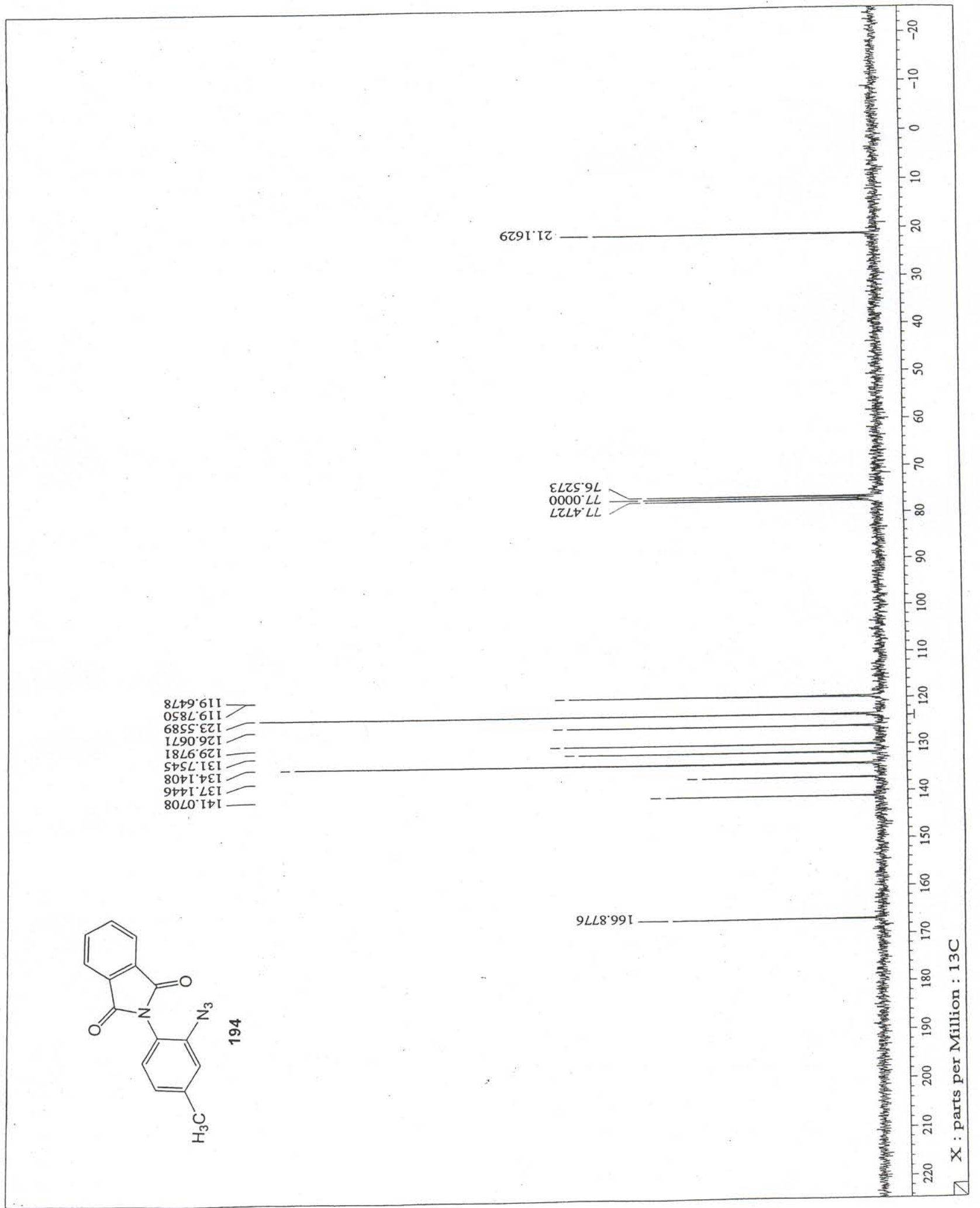

Figure 86: ${ }^{13} \mathrm{C}$ NMR of Compound 194 


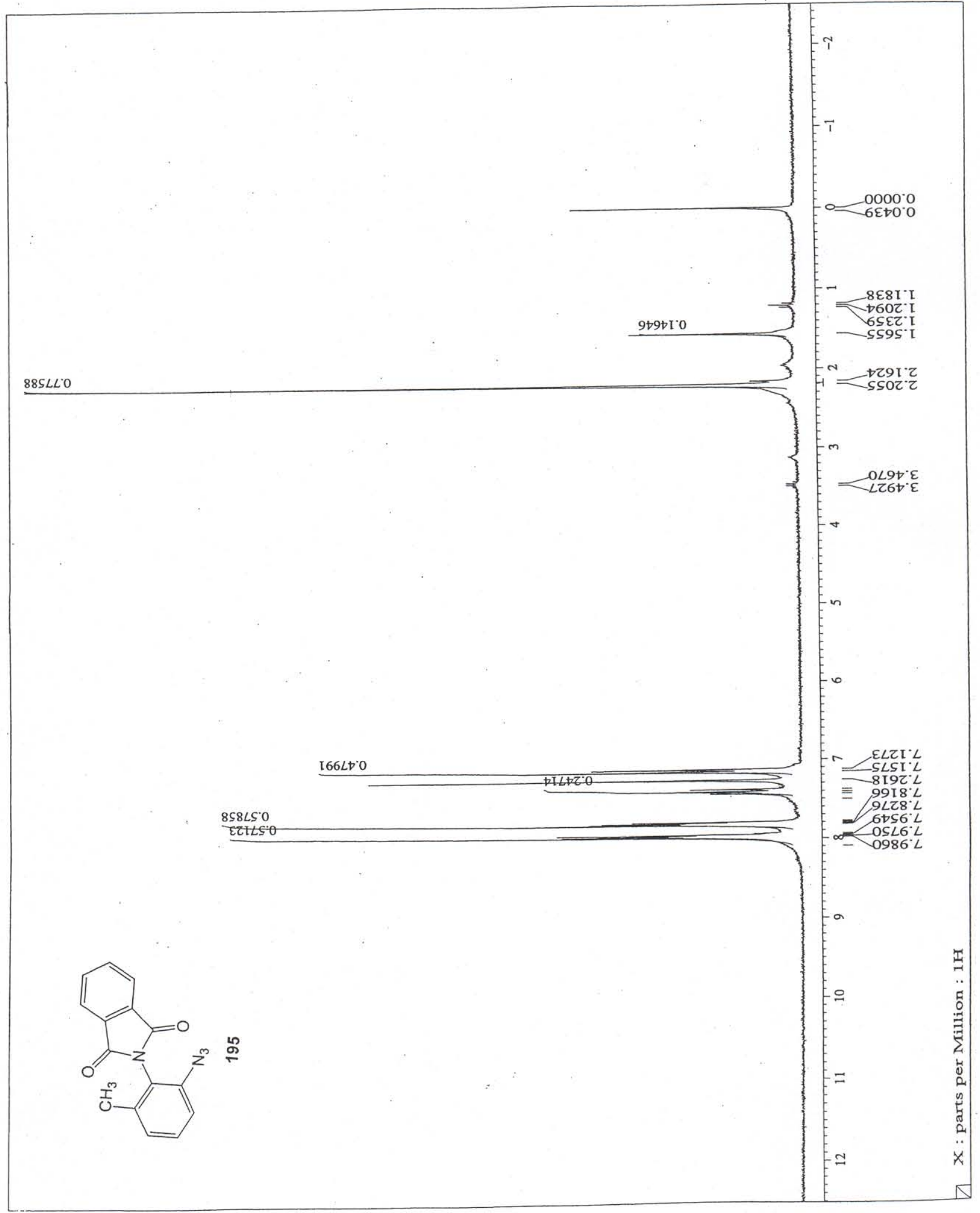

Figure 87: ${ }^{1} \mathrm{H}$ NMR of Compound 195 


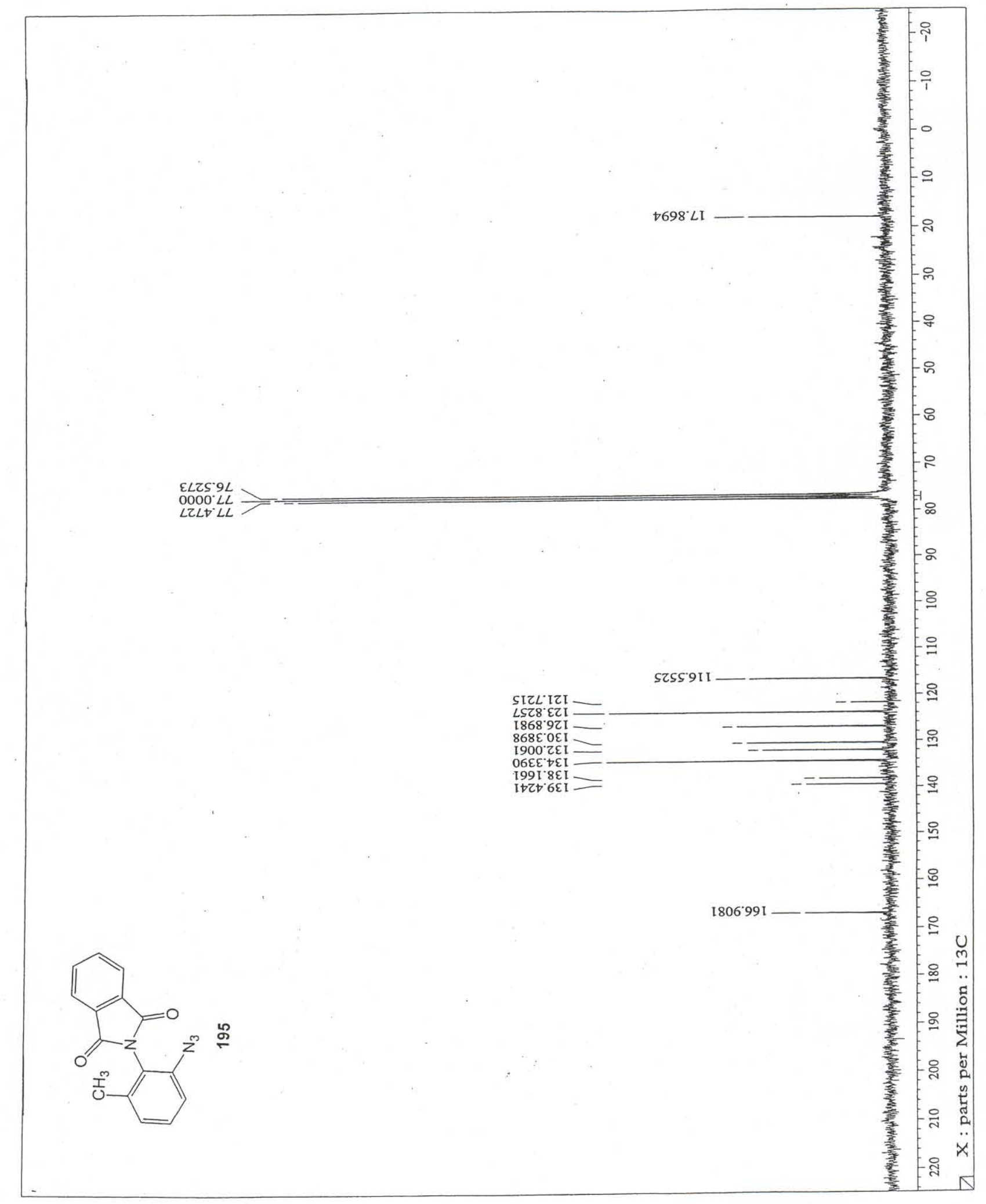

Figure 88: ${ }^{13} \mathrm{C}$ NMR of Compound 195 


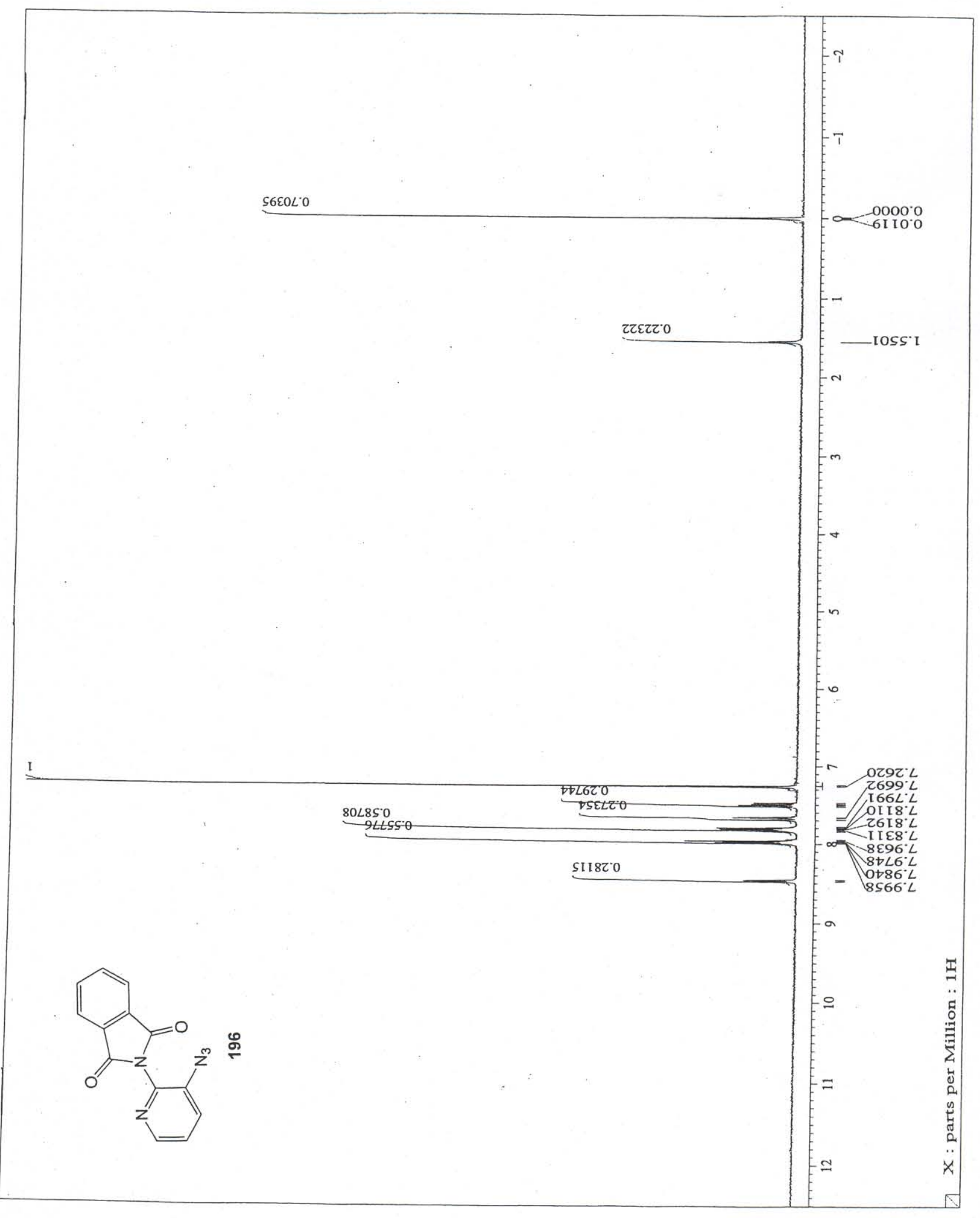

Figure 89: ${ }^{1} \mathrm{H}$ NMR of Compound 196 


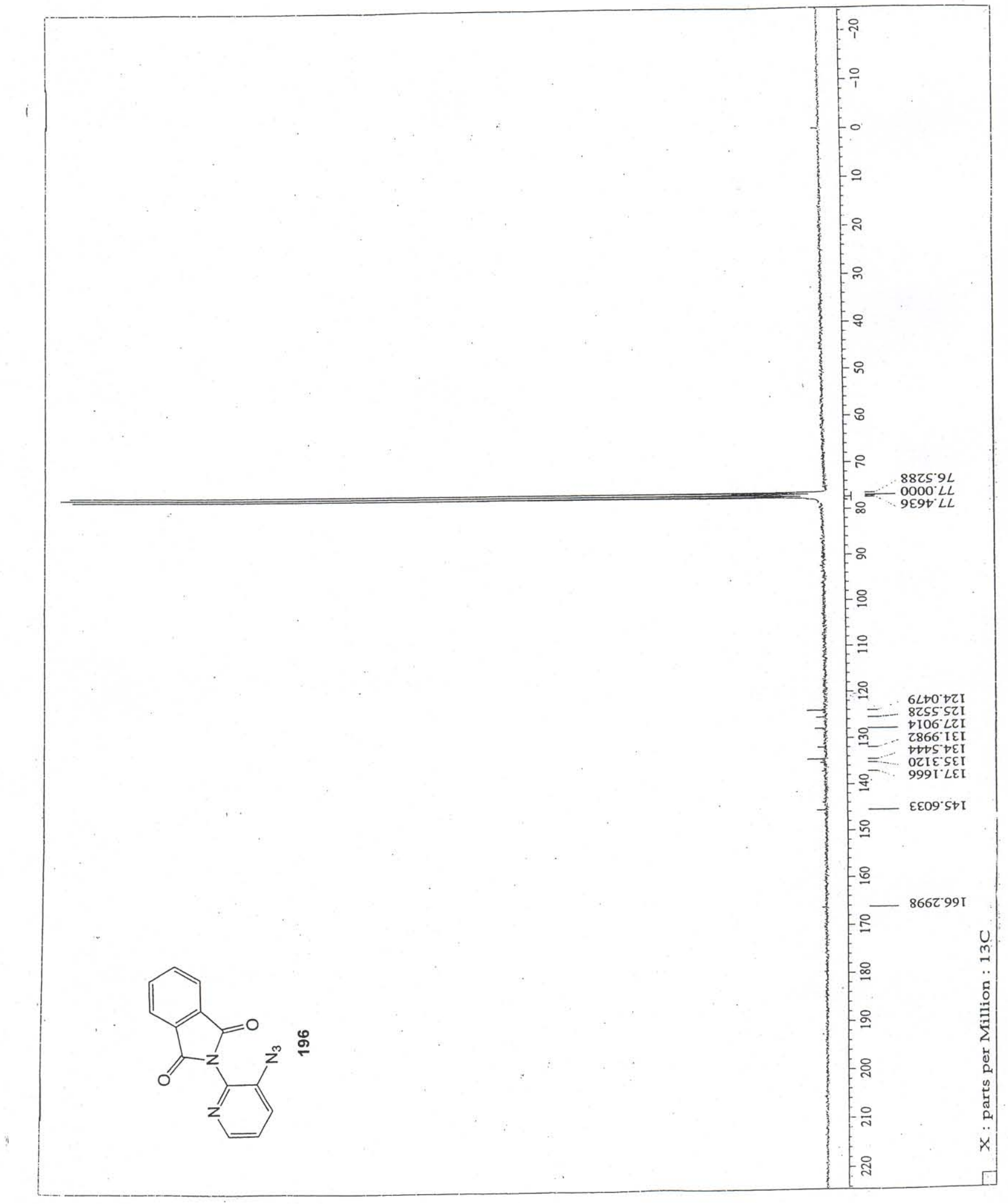

Figure 90: ${ }^{13} \mathrm{C}$ NMR of Compound 196 


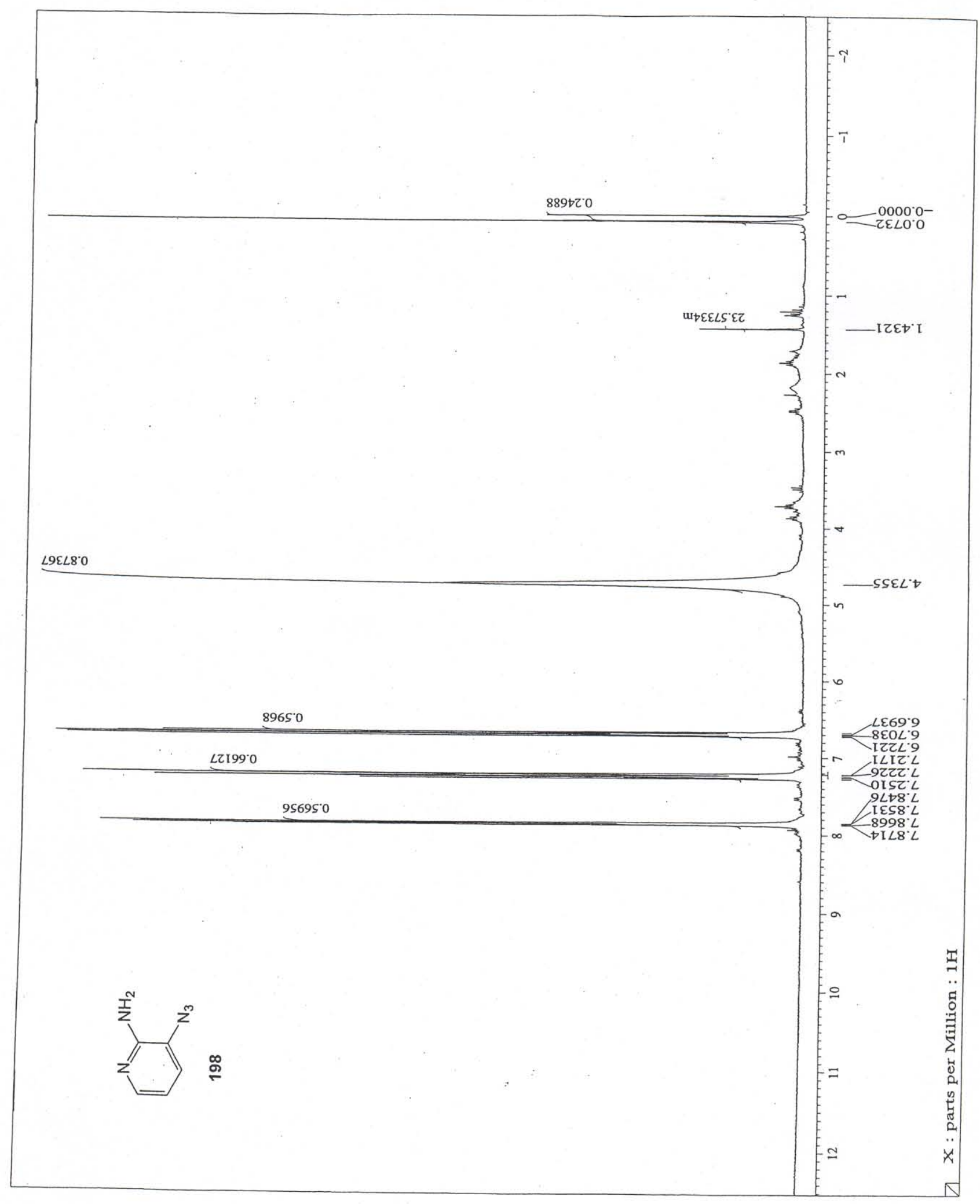

Figure 91: ${ }^{1} \mathrm{H}$ NMR of Compound 198 


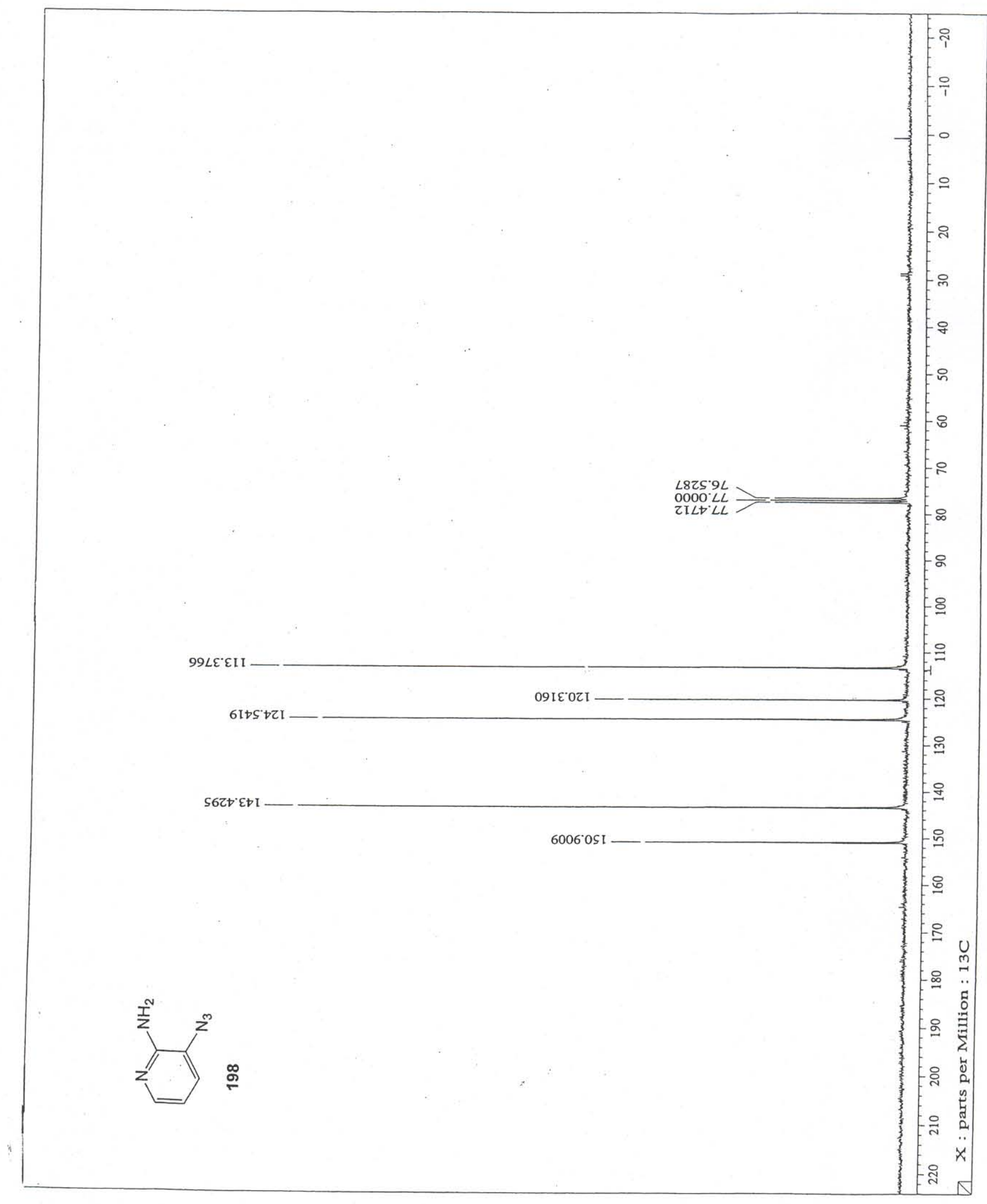

Figure 92: ${ }^{13} \mathrm{C}$ NMR of Compound 198 


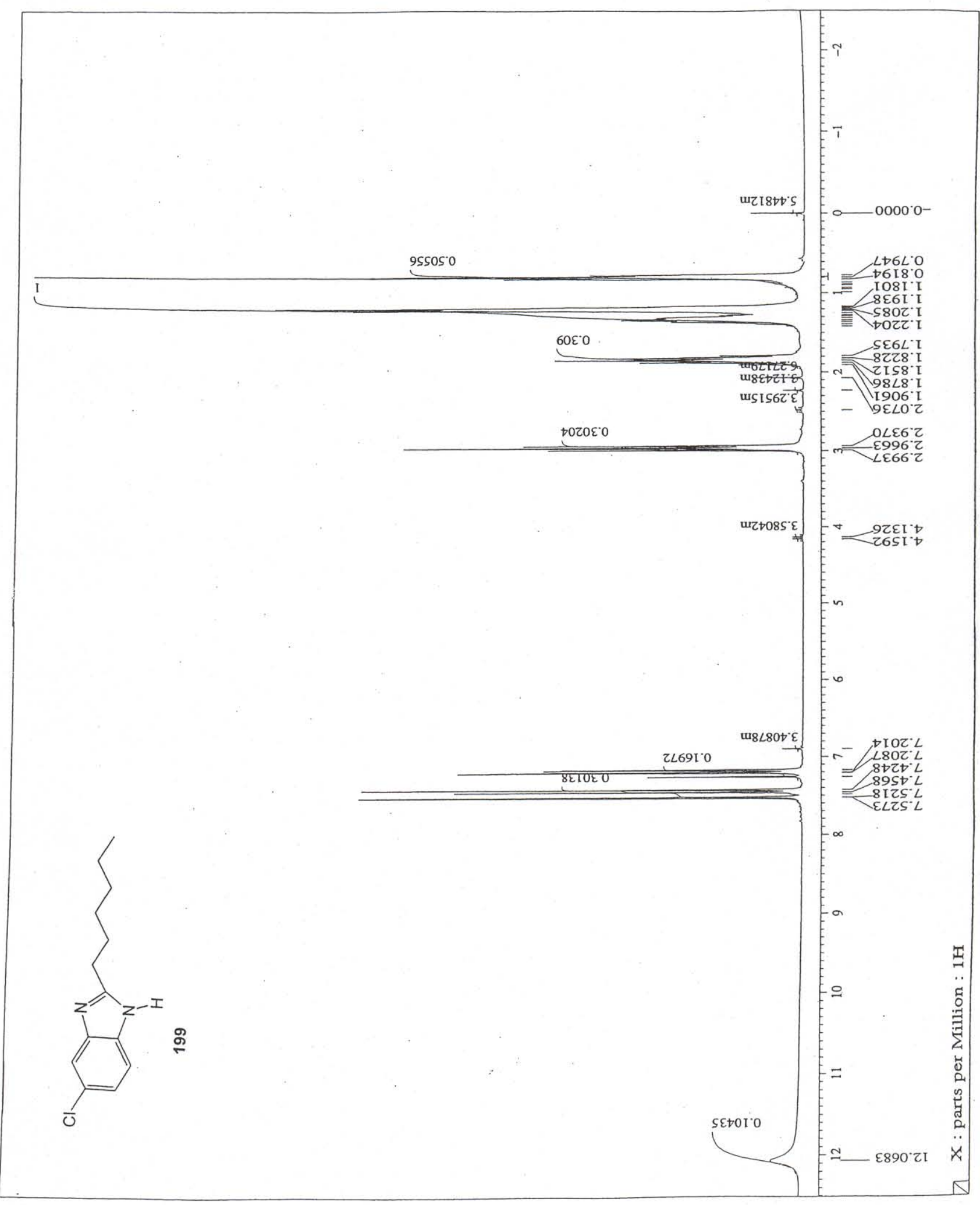

Figure 93: ${ }^{1} \mathrm{H}$ NMR of Compound 199 


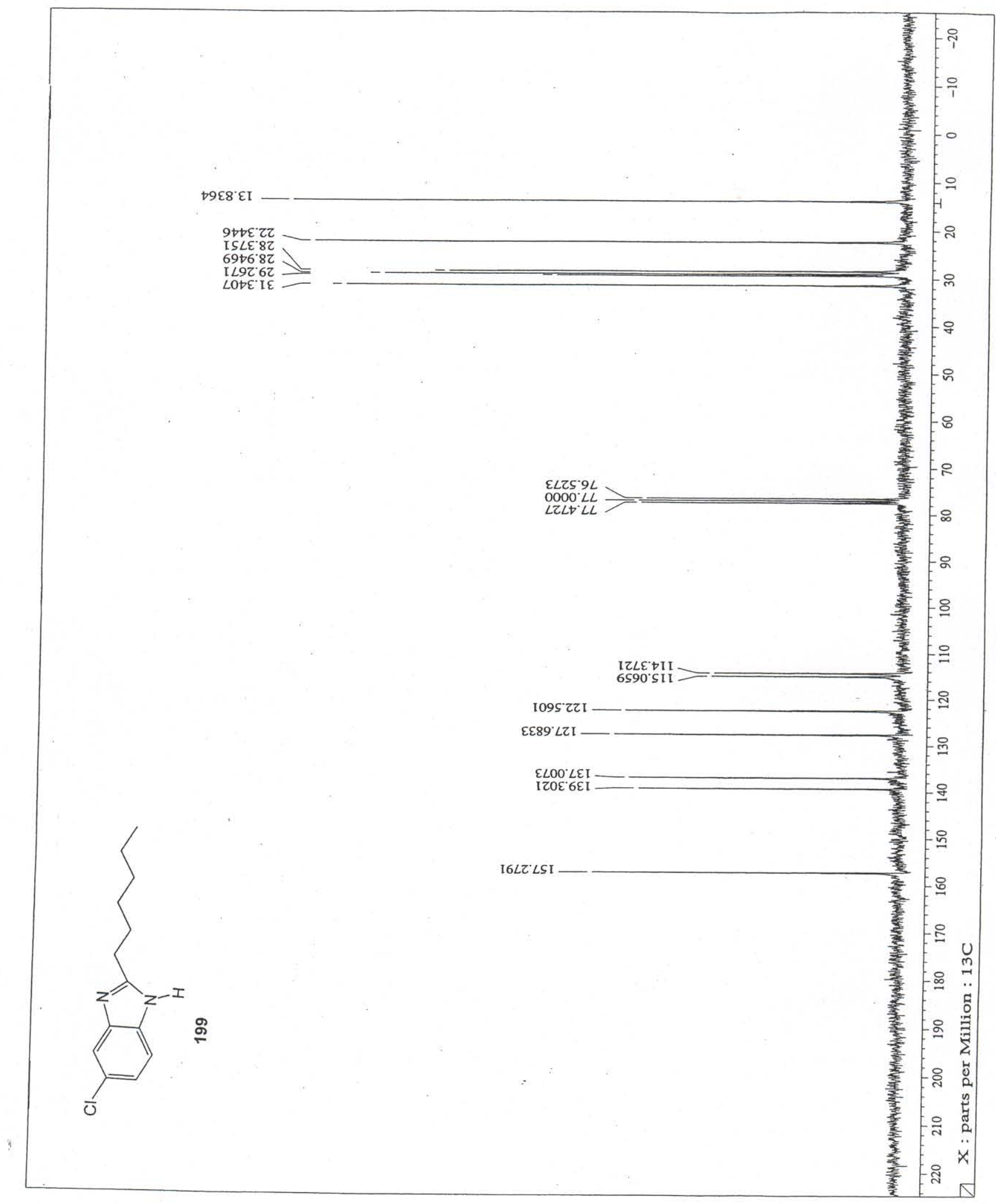

Figure 94: ${ }^{13} \mathrm{C}$ NMR of Compound 199 


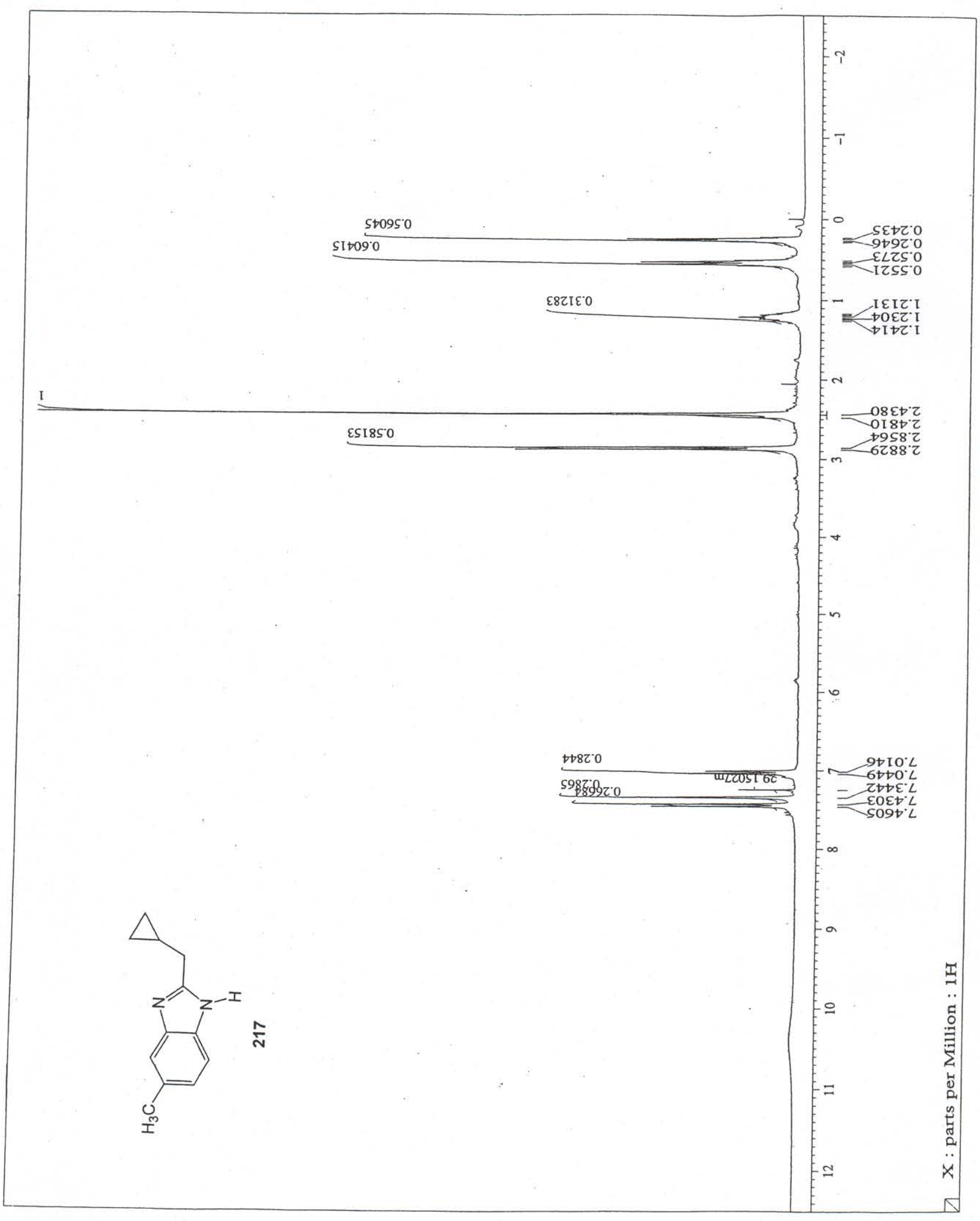

Figure 95: ${ }^{1} \mathrm{H}$ NMR of Compound 217 


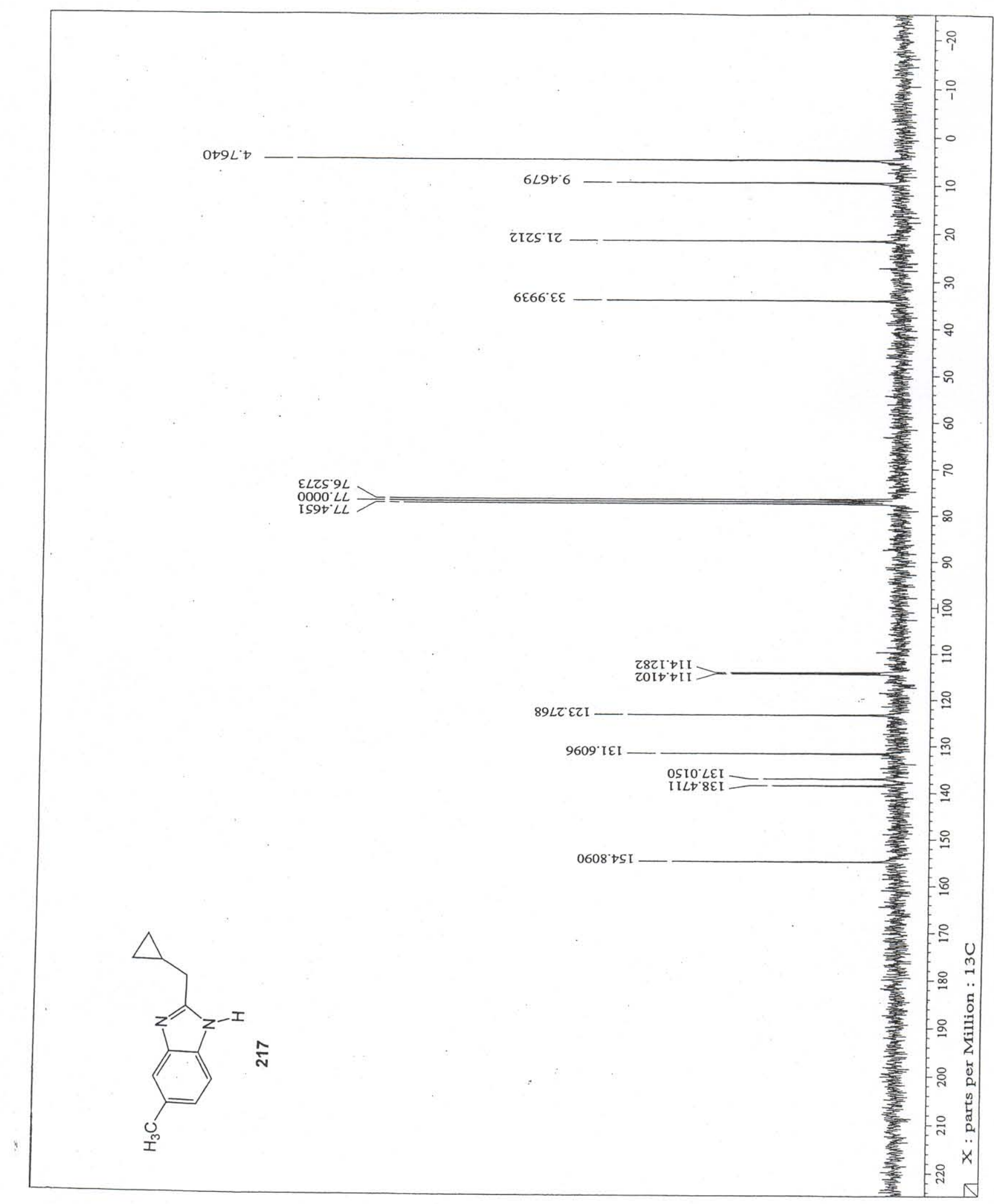

Figure 96: ${ }^{13} \mathrm{C}$ NMR of Compound 217 


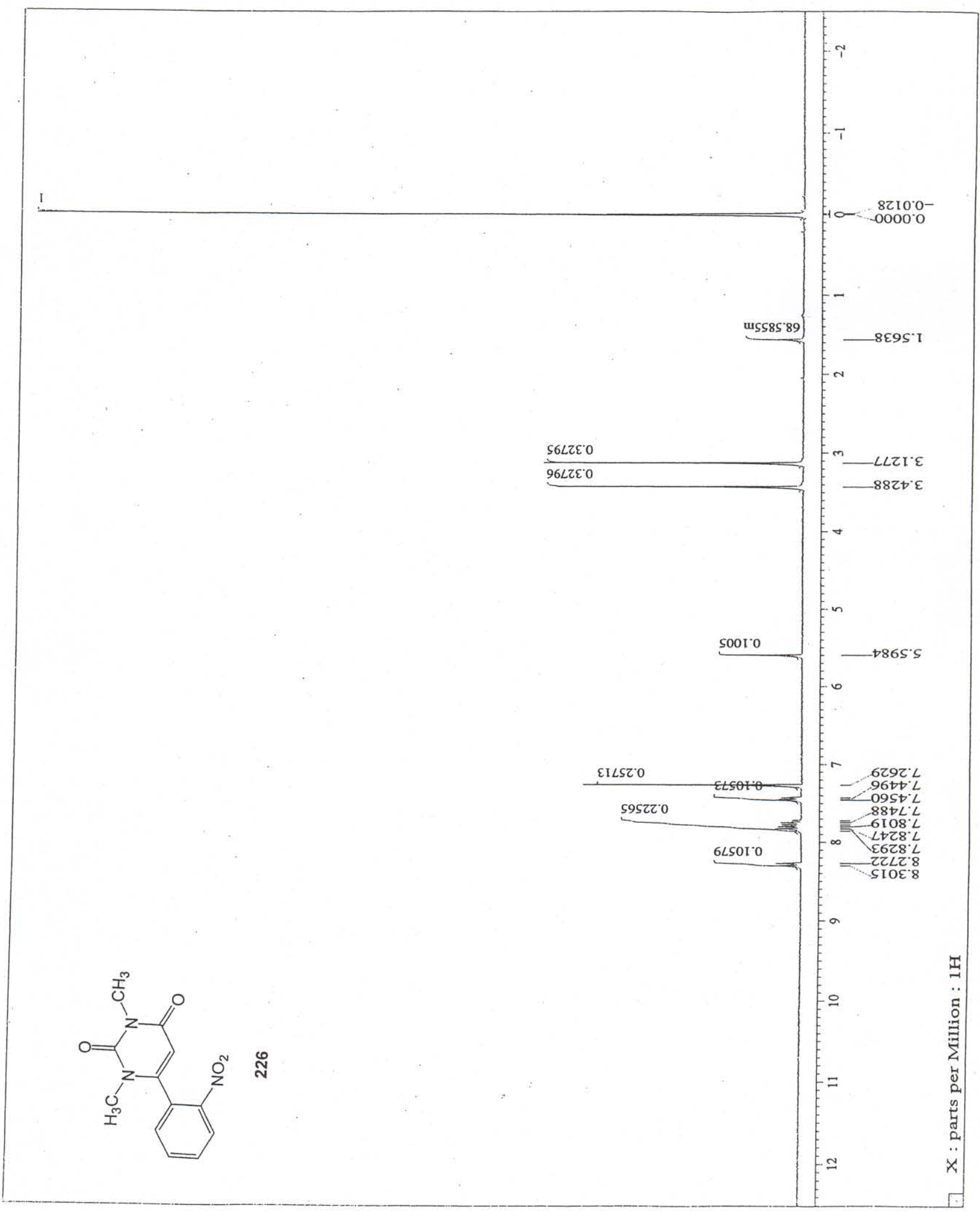

Figure 97: ${ }^{1} \mathrm{H}$ NMR of Compound 226 


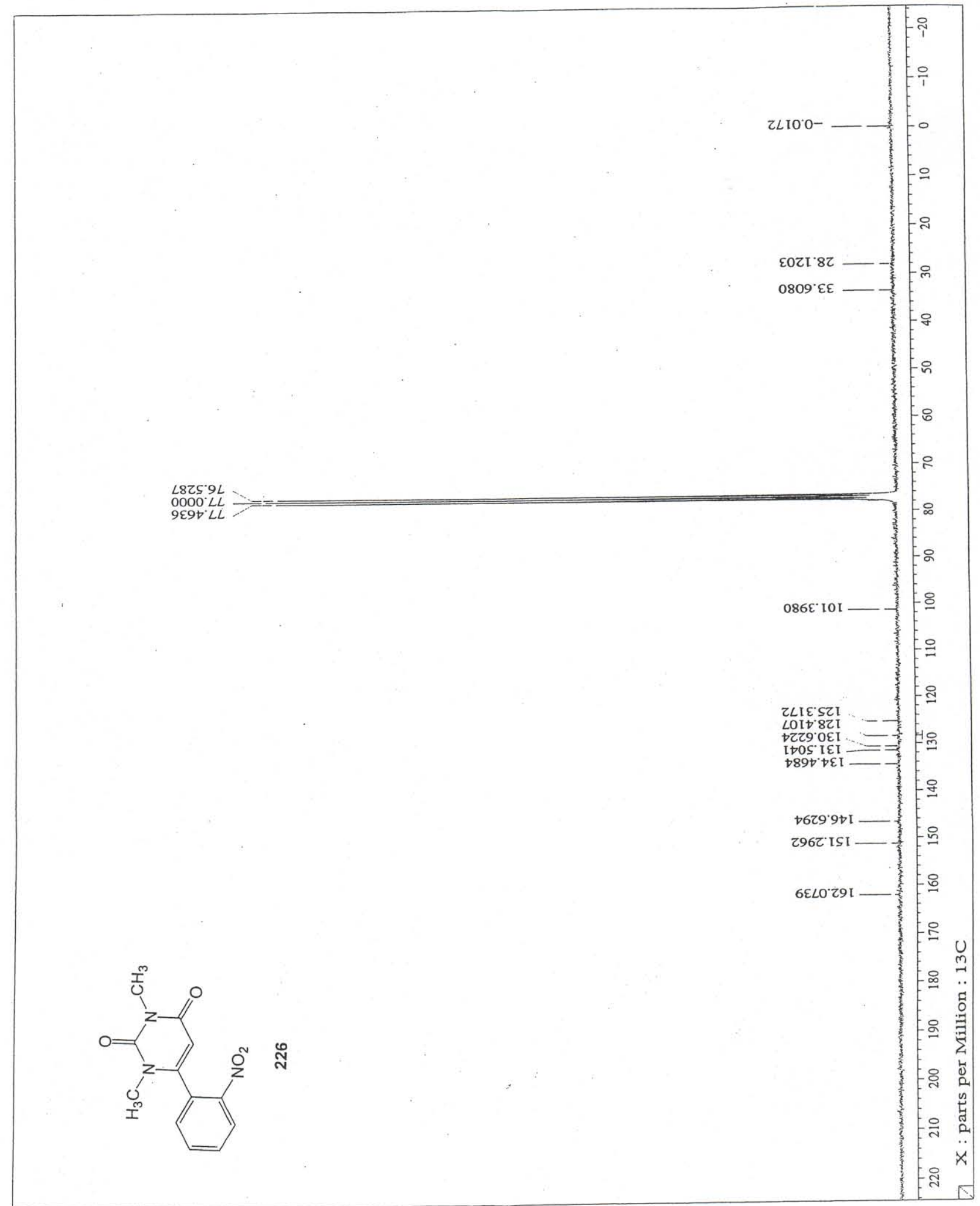

Figure 98: ${ }^{13} \mathrm{C}$ NMR of Compound 226 


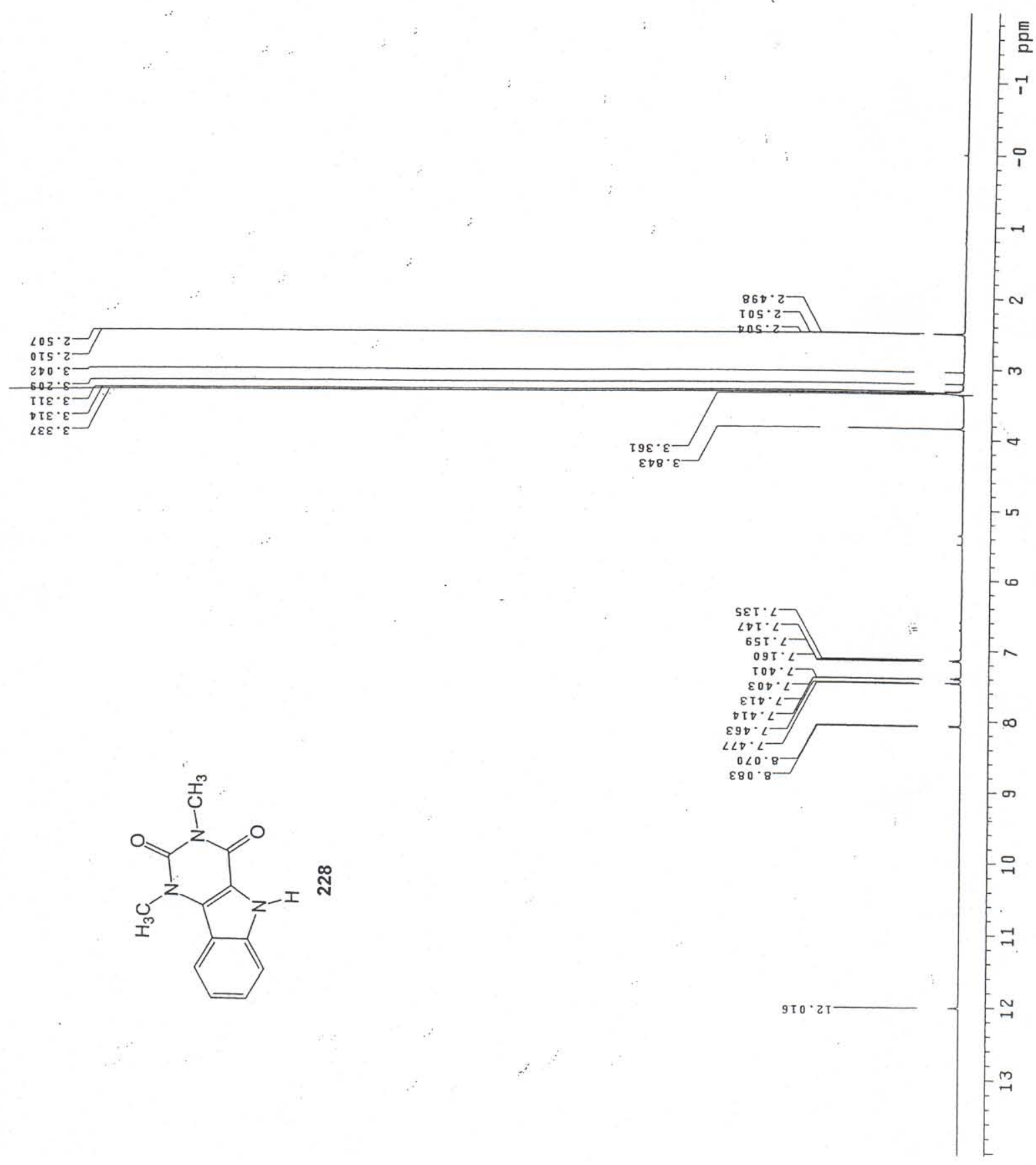

Figure 99: ${ }^{1} \mathrm{H}$ NMR of Compound 228 


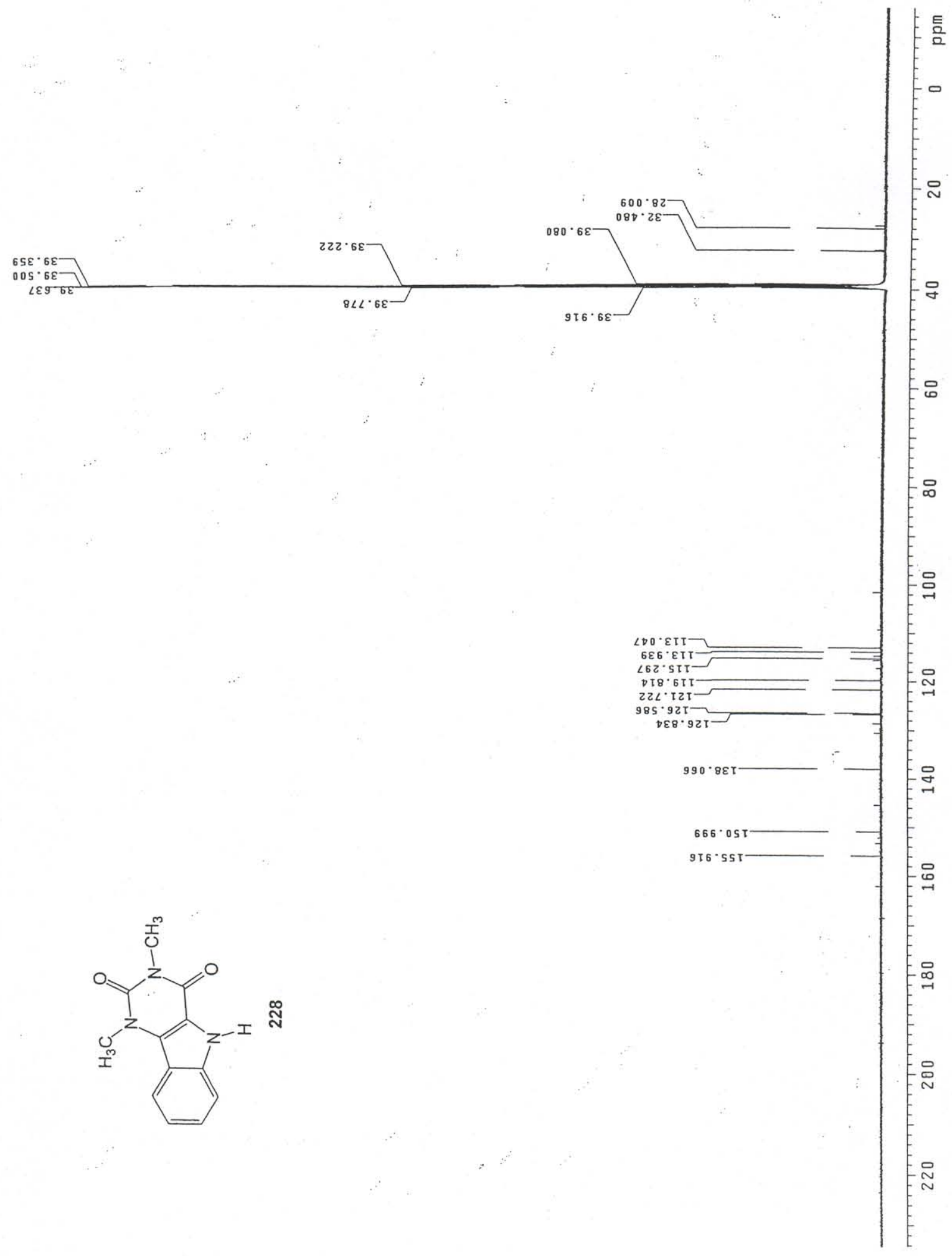

Figure 100: ${ }^{13} \mathrm{C}$ NMR of Compound 228 